\title{
Site U1356
}

\author{
Expedition 318 Scientists $^{2}$
}

\section{Chapter contents}

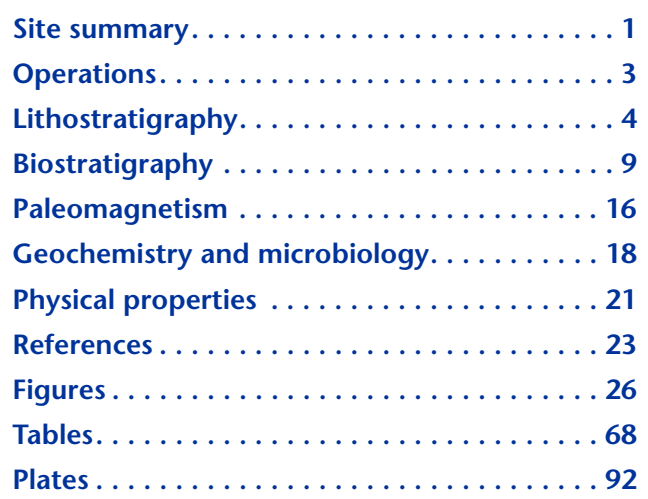

${ }^{1}$ Expedition 318 Scientists, 2011. Site U1356. In Escutia, C., Brinkhuis, H., Klaus, A., and the Expedition 318 Scientists, Proc. IODP, 318: Tokyo (Integrated Ocean Drilling Program Management International, Inc.).

doi:10.2204/iodp.proc.318.104.2011

'Expedition 318 Scientists' addresses.

\section{Site summary}

Integrated Ocean Drilling Program Site U1356 (proposed Site WLRIS-07A) is located at the transition between the continental rise and the abyssal plain at 3992 meters below sea level (Fig. F1). The main objective at Site U1356 was to core across regional unconformity WL-U3 to obtain the timing and nature of the first arrival of the ice sheet to the Wilkes Land Continental Margin in a distal setting.

Similar to Site U1355, three regional unconformities reported from the Wilkes Land margin (unconformities WL-U3, WL-U4, and WL-U5) (see the "Expedition 318 summary" chapter) are imaged at Site U1356 (Fig. F2). Unconformity WL-U3, interpreted to separate preglacial strata below from glacial strata above and presently inferred to have formed during the earliest Oligocene, occurs at $\sim 867$ meters below seafloor (mbsf) (6.33 s two-way traveltime [TWT]). Unconformities WL-U4 and WL-U5 are imaged at $\sim 708$ and 534 mbsf ( 6.15 and $5.95 \mathrm{~s}$ TWT), respectively, based on assumed velocities (Fig. F2). Coring across unconformities WL-U4 and WL-U5 was to provide a distal early Oligocene-(?)Pliocene record of glacial-interglacial (i.e., colder versus warmer) and ice sheet and sea ice variability. Multichannel seismic reflection profiles crossing Site U1356 indicated that the site would penetrate a thick sequence of stacked levee deposits developed between two deep-sea channels and above unconformity WL-U4 (Fig. F2). Based on their geometry and seismic facies associations, these levee deposits are interpreted to form when high volumes of sediment were delivered to the continental shelf edge by a wet-based East Antarctic Ice Sheet (Escutia et al., 2000). Reworking of turbidite deposits by bottom-water currents was also suspected based on the presence of wavy reflectors (Escutia et al., 2000, 2002; Donda et al., 2003). Drilling at Site U1356, therefore, would examine the earlier stages of development of large sediment levees denoted by unconformity WL-U5 in addition to the drivers for this change. Below the levee deposits and closely coinciding with unconformity WL-U4, strata are characterized by horizontal and continuous reflectors of varied amplitude that are interpreted to represent hemipelagic and distal turbidite and contourite sedimentation, based on comparisons with sediments recovered at Deep Sea Drilling Project (DSDP) Leg 28 Site 269 (Hayes, Frakes, et al., 1975).

Hole U1356A was cored to 1006.4 mbsf. The dominant lithofacies are moderately to strongly bioturbated claystone and calcareous 
claystone with Zoophycos or Nereites ichnofacies. Subordinate lithofacies include laminated silty claystones, diamictites, mudstones and sandstones with dispersed to common clasts, and graded or crosslaminated siltstones and sandstones. These facies associations are interpreted to result from hemipelagic sedimentation with variable bottom current and gravity flow influence. Wavy submillimeter-thick black concretions observed below $\sim 373$ mbsf are interpreted as a form of silica diagenesis. Carbonatecemented sandstones and conglomerates are also present below this depth.

The sedimentary section is divided into 11 lithostratigraphic units (Fig. F3).

- Units I and II (0-278.4 mbsf) are composed of diatom oozes and diatom-rich silty clays with dispersed gravel indicating hemipelagic sedimentation with ice rafting.

- Units III (278.4-459.4 mbsf), V (593.8-694.4 mbsf), and VII (723.5-782.7 mbsf) are characterized as repetitively interbedded light greenish gray bioturbated claystones and brown laminated claystones with cross-laminated siltstone and sandstone interbeds. These units are interpreted to indicate cyclical changes in bottom oxygenation, current strength, and fine-grained terrigenous sediment supply. Gravel-sized clasts are rare in these units, and only minimal evidence for ice rafting from rare dispersed sand grains is present.

- Units IV (459.4-593.8 mbsf) and VI (694.4$723.5 \mathrm{mbsf}$ ) are characterized by extensive interbeds of contorted diamictites and other gravel-bearing lithologies, indicating a strong gravity flow influence.

- Units VIII (782.7-879.7 mbsf) and IX (879.7$895.5 \mathrm{mbsf}$ ) are composed of mudstones with extensive contorted and convolute bedding.

- Unit X (895.5-948.8 mbsf) is composed of crudely stratified and graded sandstones. These units are affected by several types of mass transport, including submarine slides and slumps.

- Unit XI (948.8-1006.4 mbsf) is characterized by bioturbated claystones with subordinate stratified siltstone and sandstone, indicating hemipelagic sedimentation with minor bottom current and gravity flow influence.

- Units IX, X, and XI (below $~ 880$ mbsf) have a clay mineral assemblage dominated by smectite and kaolinite, indicating chemical weathering under relatively warm and humid conditions. This clay mineral assemblage is distinctly different from that of the overlying units (above $\sim 880 \mathrm{mbsf}$ ), where the dominant clay minerals are illite and chlorite, indicative of physical weathering in a glacially influenced environment.

Siliceous microfossils (diatoms and radiolarians), calcareous nannofossils, and organic-walled dinoflagellates (dinocysts) are the primary source of microfossilbased age control for Hole U1356A (Fig. F4). The different microfossil groups resolve the stratigraphy nearly exclusive of one another by depth. Diatoms provide a high-resolution stratigraphy for the uppermost lower Miocene to the lowermost Pliocene drape (the upper $387 \mathrm{mbsf}$ ). Calcareous nannofossils and, to a lesser extent, dinocysts resolve the Oligocene interval between $\sim 434.5$ and $\sim 875.12$ mbsf. Dinocysts provide the only microfossil age control for the lowermost Oligocene and the Eocene ( 895.5 and 995.32 mbsf). Radiolarians and planktonic foraminifers provide secondary age control, which is in agreement with the other fossil groups.

Diatoms and radiolarians suggest that the Pleistocene and all but the lowermost Pliocene (i.e., 0 to $\sim 4.2 \mathrm{Ma}$ ) are missing from Hole U1356A and that at least two other major hiatuses are centered around 4.6 and 28.38 mbsf. This indicates that much of the upper Miocene is also missing. A break in sedimentation near the Oligocene-Miocene transition is suggested by foraminifers and nannofossils. The duration of this hiatus is $\sim 6 \mathrm{~m} . \mathrm{y}$. , between 23.12 and $17.2 \mathrm{Ma}$, with most of the early Miocene missing. A relatively thick $(\sim 400 \mathrm{~m})$ Oligocene sequence is constrained by magnetostratigraphy and partially by dinocyst and nannofossil data. The very lowermost Oligocene, the upper Eocene, and most of the middle Eocene are missing in a long hiatus from 47.9 to $33.6 \mathrm{Ma}$ based on dinocyst evidence. The oldest break in sedimentation occurs in lower Eocene strata between Sample 318-U1356A-100R-1, $100 \mathrm{~cm}$, and 101R-1, $100 \mathrm{~cm}$ (940.10-949.80 mbsf). Paleomagnetostratigraphy and dinocyst stratigraphy indicate this hiatus spans from 51.90 to $51.06 \mathrm{Ma}$, practically coinciding with the boundaries between lithostratigraphic Units X and XI at 948.8 mbsf.

Three intervals with continuous enough recovery and sufficient biostratigraphic data establish a correlation to the geomagnetic polarity timescale (GPTS) (Table T1). Cores 318-U1356A-14R through 51R appear to correlate to polarity Chrons C5AAn to C5Cn.3n. A mid-Miocene hiatus could be placed just above Core 46R because the polarity stratigraphy from Cores 46R through 51R does not have a straightforward fit to Chrons 5Dn and below. Cores 68R through 92R correlate to polarity Chrons C7An$\mathrm{C} 12 \mathrm{R}$. The lowermost normal polarity interval in Core 105R and the top part of 106R corresponds to Chron C24n.3n based on biostratigraphic evidence. Core $104 \mathrm{R}$ is dominantly reverse polarity with a 
short normal polarity interval correlating to Chron C24n.2n, also based on biostratigraphic data. The top of Core 104R and all of 103R record Chron C24n.1n. Whereas Core 102R has reverse polarity and fits within Chron C23r, Core 101R could record the base of Chron 23n.2n. The correlation of Cores $100 \mathrm{R}$ and $99 \mathrm{R}$ is not straightforward because they mostly have reverse polarity, whereas Chron C23n.2n is of normal polarity. Because the transition recorded in Core $101 \mathrm{R}$ and correlation to Chron C23n.2n fits with a constant sediment accumulation-rate model extrapolating upward from the Chron C24n tie points, the hiatus is most likely positioned between Cores 101R and 100R. The smallest gap would place the transition recorded in Core 99R at the base of Chron C23.1n with Core 100R being Chron C23r in age, with a sliver of Chron C23.2n at its base (interval 318-U1356A-101R-1, $100 \mathrm{~cm}$ ). This magnetostratigraphic interpretation matches the dinocyst stratigraphy and the lithostratigraphy.

Carbonate contents for most of the section are below $2 \mathrm{wt} \%$, and levels of organic carbon, sulfur, and nitrogen are below detection limits. Major and trace elements $\left(\mathrm{SiO}_{2}, \mathrm{Al}_{2} \mathrm{O}_{3}, \mathrm{TiO}_{2}, \mathrm{~K}_{2} \mathrm{O}, \mathrm{Na}_{2} \mathrm{O}, \mathrm{MgO}, \mathrm{Fe}_{2} \mathrm{O}_{3}\right.$, $\mathrm{P}_{2} \mathrm{O}_{5}, \mathrm{Sr}, \mathrm{Ba}, \mathrm{Sc}, \mathrm{Co}$, and $\mathrm{V}$ ) show pronounced downcore variations, which can be summarized in three geochemical intervals:

1. An upper interval from 0 to $878 \mathrm{mbsf}$ where all elements show minor fluctuations, reflecting elemental association with biogenic and physically weathered terrigenous phases;

2. A transitional interval from 878 to 920 mbsf where all elemental concentrations show significant changes in their absolute values; and

3. A lower interval from 920 to 1000 mbsf where most elements show characteristics of highly weathered terrigenous material.

Physical properties generally change at the identified lithostratigraphic boundaries at Site U1356. Velocity, density, and porosity data clearly reflect the positions of features such as unconformities WL-U5 and WL-U3. The grain density increases from $\sim 2.6 \mathrm{~g} / \mathrm{cm}^{3}$ at the seafloor to $\sim 2.8 \mathrm{~g} / \mathrm{cm}^{3}$ at $1000 \mathrm{mbsf}$. Magnetic susceptibility data exhibit rhythmic changes, which are especially visible in the cores with improved recovery starting at Core 318-U1356A-47R and moreso from Core 68R downward.

\section{Operations}

\section{Transit to Site U1356}

We departed from Site U1355 at 0600 h on 22 January 2010 . The short voyage to Site U1356 was without incident except for spotting a lone iceberg both on radar and visually. The vessel was positioning at Site U1356 at $1345 \mathrm{~h}$ on 22 January. The $82 \mathrm{nmi}$ journey was made at an average speed of $10.7 \mathrm{kt}$. All times in this section are given in local ship time, which was Universal Time Coordinated $+11 \mathrm{~h}$.

\section{Site U1356}

Because of the problems starting a hole with advanced piston coring system at the previous site, we decided to start coring with the rotary core barrel (RCB) coring system. The drill string was lowered to the seafloor and the RCB bit tagged it at 4003 meters below rig floor (mbrf). This was $21.5 \mathrm{~m}$ deeper than the corrected precision depth recorder depth of 3981.5 mbrf.

RCB coring in Hole U1356A started at 0025 h on 23 January 2010. RCB Cores 318-U1356A-1R through $106 \mathrm{R}$ penetrated to $1006.4 \mathrm{mbsf}$ and recovered $350.13 \mathrm{~m}$ of core $(35 \%)$. The presence of glacial erratics below the first two cores adversely affected recovery. Recovery varied considerably from $0 \%$ to $99 \%$ but improved with depth. For example, Cores 66R through 92R penetrated $254.3 \mathrm{~m}$ of formation (622.3-876.6 mbsf) and recovered $140.58 \mathrm{~m} \mathrm{(55 \% )}$ (Table T2).

No significant hole problems were encountered. We started frequently circulating $20 \mathrm{bbl}$ of mud beginning at 296.7 mbsf. This was increased to every other core starting with Core 318-U1356A-69R (660.6 mbsf). A single $40 \mathrm{bbl}$ sweep was circulated at $631.9 \mathrm{mbsf}$ and then $20 \mathrm{bbl}$ mud sweeps were circulated at 814 , $834,852,872$, and 877 mbsf. Below this depth we circulated $20 \mathrm{bbl}$ of mud after each core.

Minor disruptions to operations occurred for $1 \mathrm{~h}$ on 27 January when the ball valve and remote actuator required servicing and when we had to make an extra wireline run to recover Core 318-U1356A-97R after the shear pin parted during the initial retrieval attempt.

The total target depth of the hole was revised as we progressed to ensure full characterization of the greenhouse to icehouse transition across the inferred Eocene/Oligocene boundary reflectors. Ultimately, coring reached $1006.4 \mathrm{mbsf}$. As soon as coring was finished, we started to prepare the hole for logging by sweeping the hole with $50 \mathrm{bbl}$ of sepiolite and then raising the drill bit back up to 103 mbsf. A tight spot was encountered at 409 mbsf. While lowering the bit back down into the hole to $476 \mathrm{mbsf}$, a ledge was encountered at 400 mbsf. The weather had deteriorated (up to $20 \mathrm{ft}$ swells; $35 \mathrm{kt}$ winds) to the point that we had to abandon the hole. Based on weather forecasts, we also thought conditions would not improve substantially for long enough to allow a 
reasonable chance to log the hole. We retrieved the drill string and by the time the drill string was recovered, the weather system had passed and the sea conditions were relatively mild. After the beacon was recovered, we began the transit to Site U1357 at 0615 h on 2 February.

The only ice seen during operations at Site U1356 occurred on 29 January when a pinnacle-shaped iceberg was detected $12 \mathrm{nmi}$ to the southeast. It was estimated to be $40 \mathrm{~m}$ high, $110 \mathrm{~m}$ long, and moving haphazardly at $\sim 0.5 \mathrm{kt}$. Two growlers were also observed visually in the general area of the iceberg. The iceberg came no closer than $10 \mathrm{nmi}$, did not impact operations, and drifted off radar at $0430 \mathrm{~h}$ on 30 January.

\section{Lithostratigraphy}

The sediments in Hole U1356A are poorly consolidated from the seabed to $\sim 373$ mbsf (Core 318U1356A-40R) and moderately to highly disturbed by drilling. Preservation of core structure improves below $\sim 373$ mbsf (Fig. F3). The dominant lithofacies throughout the hole is moderately to strongly bioturbated claystone and calcareous claystone with Zoophycos or Nereites ichnofacies. Subordinate lithofacies include laminated silty claystones, diamictites, mudstones and sandstones with dispersed to common clasts, and graded or cross-laminated siltstones and sandstones. These facies associations are interpreted to result from hemipelagic sedimentation with variable bottom current and gravity flow influence. Smear slide data (Fig. F5; see also Site U1356 smear slides in "Core descriptions") record a decrease in the relative abundance of diatoms and other siliceous microfossils from $\sim 373$ mbsf (Core 318-U1356A-40R) downward, coinciding with the appearance of carbonate and nannofossils and an increase in clay. Wavy submillimeter-thick black concretions below this depth are interpreted as a form of silica diagenesis. Carbonate-cemented sandstones and conglomerates are also present below this depth.

Based on visual core descriptions and smear slide analyses, Hole U1356A is divided into 11 lithostratigraphic units (Fig. F3). Units I and II (0-278.4 mbsf) are composed of diatom oozes and diatom-rich silty clays with dispersed gravel, indicating hemipelagic sedimentation with ice rafting. Unit II comprises more indurated sediment than Unit I. Units III (278.40-459.4 mbsf), V (593.8-694.4 mbsf), and VII (723.5-782.7 mbsf) are characterized as repetitively interbedded light greenish gray bioturbated claystones and brown laminated claystones, indicating cyclical changes in bottom oxygenation, current strength, and fine-grained terrigenous sediment supply. Gravel-sized clasts are rare in these units, and there is only minimal evidence for ice rafting from rare dispersed sand grains. Extensive interbeds of contorted diamictites and other gravel-bearing lithologies in Units IV (459.4-593.8 mbsf) and VI (694.4-723.5 mbsf) indicate a strong gravity flow influence. Units VIII (782.7-879.7 mbsf) and IX (879.7-895.5 mbsf) are composed of mudstones with extensive contorted and convoluted bedding. Unit X (895.5-948.8 mbsf) is composed of crudely stratified and graded sandstones. These units are affected by several types of mass transport, including submarine slides and slumps. Repetition of the stratigraphy is suspected for portions of these units, based on the presence of vertically oriented stratification in extensively contorted beds. The lowermost unit in the hole, Unit XI (948.8-1006.4 mbsf), is characterized by bioturbated claystones with subordinate stratified siltstone and sandstone, indicating hemipelagic sedimentation with minor bottom current and gravity flow influence.

Units IX, X, and XI (below 880 mbsf) (Fig. F6) have a clay mineral assemblage dominated by smectite and kaolinite, indicating chemical weathering under relatively warm and humid conditions. This clay mineral assemblage is distinctly different from that of the overlying units (above $\sim 880 \mathrm{mbsf}$ ), where the dominant clay minerals are illite and chlorite, indicative of physical weathering in a glacially influenced environment.

\section{Unit descriptions}

\section{Unit I}

Interval: 318-U1356A-1R-1, $30 \mathrm{~cm}$, through 14R-2, $0 \mathrm{~cm}$

Depth: 0-125.6 mbsf

Age: late Miocene-Pliocene

Unit I consists of unconsolidated clay-rich diatom ooze (Fig. F7) and diatom-rich silty clays. Rare pebblesized clasts in the silty clays at the base of the unit include granite, diorite, and metasediments. Core recovery within Unit I was low and restricted to core catchers between 19.8 and 95.4 mbsf (Cores 318U1356A-4R through 10R). Drilling disturbance precludes recognition of most sedimentary structures, although occasional strongly bowed mud laminae and sand stringers were observed.

\section{Interpretation}

The high biogenic and low terrigenous content of these sediments indicates hemipelagic sedimentation in a high-productivity environment and/or a low-terrigenous sediment supply. Stratification is likely caused by current sorting, although drilling disturbance precludes a definitive diagnosis. The 
presence of dispersed gravel-sized clasts likely indicates ice rafting.

\section{Unit II}

Interval: 318-U1356A-14R-2, $0 \mathrm{~cm}$, through 30R-1, $90 \mathrm{~cm}$

Depth: 125.6-278.40 mbsf

Age: middle Miocene

Unit II consists of olive-brown interbedded diatom ooze and laminated diatom-rich silty clay. This unit is distinguished from Unit I on the basis of increased consolidation of the sediments, resulting in less disturbance by RCB drilling and preservation of original bedding structures. Core recovery and preservation in the upper $\sim 125 \mathrm{mbsf}$ (Unit I) is extremely low, and the top of Section 318-U1356A-14R-2 is the first occurrence of sedimentary structures preserved in drilling biscuits. Two styles of laminae occur within Unit II: (1) intervals of millimeter- to centimeterscale light and dark color alternations (Fig. F8) and (2) intervals that contain submillimeter-scale (pinstripe) laminae of silt-sized grains. Locally, the sediments contain rhythmic couplets of diatom-rich and diatom-poor claystone laminae. Dispersed gravel clasts of various lithologies (granites, diorite, and metasediments) occur regularly throughout this unit, with a higher concentration below $162.5 \mathrm{mbsf}$. Occasional clusters or beds $(<10 \mathrm{~cm})$ of coarse sand grains and granules are also observed. Bioturbation is sparse to absent throughout. An isolated carbonatecemented claystone in a drilling biscuit contains subhorizontally oriented burrows with backfill.

\section{Interpretation}

The high-biogenic and low-terrigenous content of these sediments indicates hemipelagic sedimentation in a relatively high productivity environment. Submillimeter-scale laminations likely result from current sorting. The pebble-sized clasts and coarse sand clusters or interbeds likely indicate ice rafting.

\section{Unit III}

Interval: 318-U1356A-30R-1, $90 \mathrm{~cm}$, through 49R$1,0 \mathrm{~cm}$

Depth: 278.40-459.4 mbsf

Age: late early middle Miocene

Unit III is differentiated from Unit II on the basis of increased bioturbation and a lack of gravel-sized clasts. The boundary between Units II and III is gradational. This unit exhibits repetitive interbedding of light greenish gray biogenic or bioturbated (silty) claystones and dark olive-brown laminated claystones, with average bedding thicknesses between $\sim 0.5$ and $3.0 \mathrm{~m}$. Diatom-bearing to diatom-rich (silty) claystones are dominant above $373.2 \mathrm{mbsf}$, and diatoms decrease in abundance below this depth. Rare ripple cross-laminated sandstone beds and laminae are present below 373.2 mbsf. The proportion of nannofossils and carbonate-cemented beds increases significantly at the base of the unit (below $442.46 \mathrm{mbsf}$ ). The increased consolidation of this unit allowed identification of trace fossil assemblages. Subhorizontally aligned backfilled burrows are interpreted as Zoophycos, whereas Chondrites-style burrows are also identified, suggesting alternations between Zoophycos and Nereites ichnofacies.

The first downhole amorphous silica cement is recorded within Core 318-U1356A-35R ( 327 mbsf). From Core 318-U1356A-40R ( 373 mbsf) downward, the well-preserved biogenic silica component in smear slides decreases, whereas amorphous silica fragments increase in abundance. Toward the base of Unit III, biogenic silica is present only as trace diatom fragments and, when present, is commonly replaced by pyrite. Coincident with the absence of diatoms are distinctive wavy submillimeter-scale black concretions that crosscut in situ sedimentary structures. Interval 318-U1356A-40R-1, 13-17 cm, also marks the first downhole occurrence of in situ carbonate-cemented sandstone.

\section{Interpretation}

The cyclic alternations between laminated and bioturbated claystone facies are indicative of hemipelagic sedimentation with variability in bottom current strength and fine-grained terrigenous supply. The lack of gravel-sized clasts suggests minimal iceberg rafting. The poor preservation of diatoms below $\sim 373$ mbsf is interpreted to be caused by diagenetic alteration of biogenic opal. The wavy submillimeterthick black concretions observed below this depth persist until the bottom of the hole and are interpreted as a form of silica diagenesis.

\section{Unit IV}

Interval: 318-U1356A-49R-1, $0 \mathrm{~cm}$, through 63R-1, $41 \mathrm{~cm}$

Depth: 459.4-593.8 mbsf

Age: late Oligocene

Unit IV is characterized by lithologies that contain gravel-sized clasts interbedded with intervals of alternating bioturbated claystones and cross-laminated and decimeter-scale graded silty claystones (Fig. F9). The top of the unit is placed at the top of a bed of diamictite. Occasional $<1 \mathrm{~m}$ thick calcareous and rare nannofossil-bearing interbeds are present within the bioturbated claystones. Coarse-grained lithologies include diamictites, conglomerates, and silty claystones with dispersed to common clasts. Where 
diamictites overlie claystones, laminae of the underlying units are commonly contorted and sheared (Fig. F9). Internal bedding in the diamictites is often strongly contorted, and rotational shear features are common. Occasional sand-filled clastic dikes are present. Clast composition in the clast-bearing lithologies is diverse and includes granite, diorite, and metasediments, as well as common intraformational clasts of variable claystone facies. Shell fragments are locally present within the coarse-grained facies.

\section{Interpretation}

The clast-bearing lithologies in this unit are interpreted as a combination of debris flow deposition and ice rafting. Deformational features and intraclasts in the diamictites result from gravity flows. Thin, decimeter-scale graded silty claystones could have been produced by turbidity currents. Intermittent pelagic and hemipelagic sedimentation with bottom current influence is indicated by the interbeds of calcareous, bioturbated, and laminated claystones.

\section{Unit V}

Interval: 318-U1356A-63R-1, $41 \mathrm{~cm}$, through 73R$4,72 \mathrm{~cm}$

Depths: 593.8-694.4 mbsf

Age: late Oligocene

Unit V consists of light greenish gray strongly bioturbated claystones and micritic limestones interbedded with dark brown, sparsely bioturbated, parallellaminated claystones. Minor cross-laminated sandstone interbeds are present as well. The top of Unit V is at the base of a diamictite at $593.8 \mathrm{mbsf}$. Gravel is absent below this depth to the base of Unit V, and sand-sized grains are rare. Lithologic successions are locally strongly cyclic with repetitions of sharp-based dark brown laminated claystones that transition upward into the light greenish gray bioturbated claystones with lighter colored calcareous claystones or limestones at the top (Fig. F10). The laminated claystone contains packages of $<6 \mathrm{~mm}$ thick silt laminae (with pinstripe lamination and ripple cross-lamination) and $<3 \mathrm{~cm}$ thick cross-laminated sandstone interbeds. Intervals containing rhythmic couplets of dark and light laminae (millimeter to centimeter scale) are present locally. Smear slides indicate that most silt laminae are composed of well-sorted quartz. This is confirmed by a bulk X-ray diffraction (XRD) analysis of two laminae from Core 318-U1356A-68R (XRD samples at interval 318-U1356A-68R-3, 27-28 cm). Ichnofossils within this unit include Chondrites and subhorizontal Zoophycos.

\section{Interpretation}

The bioturbated and calcareous claystones and limestones represent pelagic and hemipelagic sedimenta- tion. The absence of gravel and presence of rare dispersed sand grains indicate that ice rafting was not an important sedimentary process. The laminated claystones and ripple cross-laminated sandstones probably indicate variations in bottom current strength and fine-grained terrigenous supply. The sharp-based facies successions indicate that sedimentation was strongly cyclic.

\section{Unit VI}

Interval: 318-U1356A-73R-4, $72 \mathrm{~cm}$, through 76R$4,134 \mathrm{~cm}$

Depth: 694.4-723.5 mbsf

Age: early late Oligocene

Unit VI is dominated by contorted beds of mudstones with dispersed $(<1 \%)$ to common $(1 \%-5 \%)$ clasts of various lithologies, including granite and diorite (Fig. F11). These intervals are interbedded with thinner ( 1-2 $\mathrm{m}$ thick) intervals of bioturbated claystones and carbonate-bearing claystones. The top of the unit is marked by the first downhole occurrence of a contorted claystone with dispersed clasts. The beds of clast-bearing mudstone are characterized by soft-sediment mixing and rotational shear features, as well as abundant (5\%-30\%) intraformational clasts of mudstone. The basal contacts of the deformed mudstones with clasts are sharp, and in situ bioturbation is absent in these beds.

\section{Interpretation}

Beds of mudstones with clasts may represent the distal ends of debris flows affecting an environment characterized by hemipelagic sedimentation, represented by the bioturbated claystones and carbonate-bearing claystones. The abundant mudstone intraclasts are interpreted as rip-up clasts derived from the underlying bioturbated claystone lithologies.

\section{Unit VII}

Interval: 318-U1356A-76R-4, $134 \mathrm{~cm}$, through $82 \mathrm{R}-6,37 \mathrm{~cm}$

Depth: 723.5-782.7 mbsf

Age: middle Oligocene

Unit VII consists of bioturbated claystones and calcareous claystones interbedded with laminated to massive claystones. The lithologies are similar to those observed in Unit V. The upper boundary of Unit VII is placed at the top of a laminated claystone. Bed thicknesses are generally $\sim 0.5-3.0 \mathrm{~m}$. Silt laminae are present as either pinstripe (submillimeter scale) or parallel laminations and ripple cross-laminations up to $10 \mathrm{~mm}$ thick. Gravel-sized clasts are absent. Ichnofossils within this unit include Chondrites and subhorizontal Zoophycos. 


\section{Interpretation}

The bioturbated and calcareous claystones and limestones represent pelagic and hemipelagic sedimentation. The pinstripe laminated and ripple cross-laminated claystones probably indicate variations in bottom current strength and fine-grained terrigenous supply.

\section{Unit VIII}

Interval: 318-U1356A-82R-6, $37 \mathrm{~cm}$, through 93R$3,61 \mathrm{~cm}$

Depth: 782.7-879.7 mbsf

Age: early Oligocene

Unit VIII consists of interbedded bioturbated claystones, calcareous claystones, laminated claystones, and massive structureless claystones. The bioturbated claystones are characterized by Zoophycos ichnofacies. Ripple cross-lamination in laminated silty claystones is common. Locally, decimeter-thick sand and granule-rich interbeds are present. Contorted or inclined bedding, intraformational clasts (Fig. F12), and synsedimentary microfaults are common throughout this unit. Convolute bedding with vertical orientation of stratification signals possible repetition of stratigraphy on a meter scale at $\sim 807-810$ and $~ 824-832$ mbsf (Cores 318-U1356A-85R and $87 \mathrm{R}$, respectively).

\section{Interpretation}

The bioturbated claystones and laminated claystones indicate hemipelagic deposition. Ice rafting could be responsible for the gravel component in the sediments. Contorted bedding results from mass movement. The convolute bedding and possible repetition of stratigraphy with preservation of undeformed beds between deformed intervals suggests that submarine slides and slumps occurred periodically during deposition of the unit.

\section{Unit IX}

Interval: 318-U1356A-93R-3, $61 \mathrm{~cm}$, through 95RCC, $0 \mathrm{~cm}$

Depth: 879.7-895.5 mbsf

Age: earliest early Oligocene

Unit IX is composed of light green laminated claystones, dark green massive (structureless) claystones, and contorted massive and stratified sandstones. It is distinguished from Unit VIII by a color change to distinct green lithologies, the appearance of massive (structureless) claystones, and the presence of sandstone interbeds. Locally, beds are composed of convoluted mudstones and sandstones with vertical stratification and abundant intraformational mudstone clasts. Repetition of a conspicuous green mudstone lithology on a meter scale is also observed. Therefore, repetition of stratigraphy is suspected.

\section{Interpretation}

The claystones probably indicate hemipelagic sedimentation, whereas the sandstones indicate stronger winnowing by currents or gravity flow. Repetition of stratigraphy and convolute bedding suggests that submarine slides and slumps were a dominant type of mass movement. Alternatively, proglacial or subglacial deformation of strata may have occurred.

\section{Unit X}

Interval: 318-U1356A-95R-CC, $0 \mathrm{~cm}$, through 101R-1, $0 \mathrm{~cm}$

Depth: 895.5-948.8 mbsf

Age: late early to early middle Eocene

Unit X consists of interbedded stratified and massive sandstones, diamictites, silty claystones, and siltstones with graded bedding and parallel lamination. The upper boundary of Unit X marks the top of a section with fining-upward and coarsening-upward beds that are stratigraphically intact. Contorted bedding is occasionally present in the clast-bearing sandstones and diamictites. Abundant intraformational clasts are present in the fining-upward sandstones. The sandstones also contain mica and pyritized shell fragments. In the lowermost intervals of this unit, distinctive reddish brown silty claystones are repetitively interbedded at the decimeter to meter scale with greenish gray and brown sandy mudstones with parallel laminae.

\section{Interpretation}

The presence of contorted bedding in clast-bearing sandstones and diamictites and graded sandstones and siltstones in Unit X could indicate an environment with debris flows and turbidity currents or, alternatively, a storm wave-influenced environment in a shallower setting, as indicated by the micaceous fining-upward sandstone beds. The distinctive interval of interbedded reddish brown claystones and greenish gray-brown sandy mudstones likely resulted from changes in bottom current intensity or episodic gravity flow. The anomalous colors of these beds may have resulted from differential postdepositional redox reactions in the different lithologies caused by changing oxygenation conditions upon burial.

\section{Unit XI}

Interval: 318-U1356A-101R-1, $0 \mathrm{~cm}$, through 106R-CC, $17 \mathrm{~cm}$

Depth: 948.8-1006.4 mbsf

Age: early Eocene 
The dominant lithology in Unit XI consists of dark green bioturbated claystone that is faintly stratified (millimeter to meter scale) as defined by color variations (light to dark bands). The upper boundary of this unit is defined by an abrupt downward change from sandstone-dominated lithologies (Unit X) to claystone-dominated lithologies. Semihorizontal backfilled burrows are present in the claystone and, although these have been compressed by sediment compaction, they likely represent Zoophycos. This interval has rare interbeds of massive or cross- and parallel-laminated fine sandstone and siltstone as thick as $6 \mathrm{~cm}$. The sandstones contain mica. One $\sim 0.3 \mathrm{~m}$ thick interval of highly indurated, massive, poorly sorted, very angular fine to medium quartzose sandstone is present. The sandstone is also micaceous, like the other sandstone beds in this unit. One enigmatic mafic igneous pebble was also observed in a strongly fractured interval at 318-U1356A-104R-1, 46-47 cm (Fig. F13).

\section{Interpretation}

The bioturbated claystones were likely deposited through hemipelagic sedimentation. The rare laminated siltstone and sandstone interbeds probably indicate sporadic gravity flows or bottom current activity, although these processes appear to be much less common than in overlying units.

The $0.3 \mathrm{~m}$ thick sandstone interval may constitute the cored component of a boulder-sized clast, as there is no lithologic change in the underlying or overlying lithologies, and the basal contact of this bed is very sharp and "V-shaped," although disturbed by drilling. Alternatively, this sandstone interval may constitute a cemented bed of immature sandstone. A sandy debris flow origin is envisioned, based on the angular nature of the grains and the presence of matrix, including fragile micas that would not survive extensive traction transport.

Zoophycos and Nereites communities are commonly associated with the environmental conditions found in bathyal to abyssal depositional settings (Seilacher, 1967). However, they may be found in shallower depths when influenced by other factors, especially oxygen levels in the case of Zoophycos (Frey et al., 1990).

\section{Clay mineralogy}

Approximately 100 samples from Hole U1356A were prepared for XRD analysis of clay mineral assemblages. Strong reflection patterns were obtained from 92 of these samples. Results from preliminary assessment of the data are presented in Figure F6. Four clay intervals defined in the hole, CI, CII, CIII, and CIV, are characterized by similar clay mineralogy.

\section{Intervals}

The uppermost interval, CI, ranges from Sample 318U1356A-1R-2, 49-51 cm, to 2R-6, $57 \mathrm{~cm}$ (2.01$17.58 \mathrm{mbsf})$. The clay mineral assemblage in this interval is dominated by smectite and illite, with a minor component of kaolinite (Fig. F6). Chlorite was not identified in the three samples analyzed from this interval.

Clay interval CII spans the thick section between Samples 318-U1356A-3R-CC, $6 \mathrm{~cm}$, and 93R-2, 38$39 \mathrm{~cm}$ (19.64-878.34 mbsf). The clays in this interval are dominated by a mixture of illite, chlorite, and smectite, with only trace amounts of kaolinite. An apparent downcore increase in the amount of smectite associated with a concomitant decrease in illite occurs in the lower part of this interval between $\sim 600$ and 878 mbsf (Fig. F6).

A thin interval between Samples 318-U1356A-93R-3, 100-101 cm, and 95R-4, 47-48 cm (880.06$895.42 \mathrm{mbsf})$, is identified as clay mineral interval CIII. Samples from this interval are dominated by smectite, with a very minor component of illite, chlorite, and kaolinite. Two samples from this interval (Samples 318-U1356A-93R-3, 100-101 cm, and 95R-4, 47-48 cm) contain a near-monomineralic assemblage of highly crystalline smectite.

The lowermost clay interval of the hole, CIV, is between Sample 318-U1356A-96R-CC, 16-17 cm, and 106R-1, 75-77 cm (900.77-997.55 mbsf). The clay fraction in samples from this interval is composed primarily of smectite and kaolinite, with very minor amounts of illite. One exception to this characterization is Sample 318-U1356A-104R-3, 133-134 cm (981.88 mbsf), which is dominated by an illite group mineral. Mica-bearing sandstones are present within lithostratigraphic Units IX-XI. Sample 318-U1356A104R-3, 133-134 cm, was taken from a claystone interval, but it is possible that some of the finer grained lithologies also contain mica.

The most prominent overall change in clay mineral assemblages in Hole U1356A occurs at the boundary between clay intervals CII and CIII ( $~ 880 \mathrm{mbsf})$, corresponding to the boundary between lithostratigraphic Units VIII and IX. At this level, there is sharp downcore decrease in illite and chlorite and an increase in kaolinite (Fig. F6). The succession above $\sim 880$ mbsf is assigned an age of early Oligocene to Pliocene (see "Biostratigraphy"). The presence of abundant chlorite and illite in this interval suggests a low degree of chemical alteration of clay minerals during transport and deposition in the hemipelagic environment at Site U1356. The illite and chlorite mineral groups represent fresh weathering products produced as a result of physical erosion of metamorphic and granitoid igneous parent rocks by glaciers. 
Similar clay mineral assemblages are documented in early Oligocene to early Miocene cores on the Antarctic margin and in the Southern Ocean (e.g., Ehrmann, 1991; Robert et al., 2002; Ehrmann et al., 2005) and are interpreted as the weathering products of widespread glacial activity in East Antarctica through this time interval.

The distinct shift to smectite- and kaolinite-dominated clays below $\sim 880$ mbsf (clay intervals CIII and CIV; Fig. F6) corresponds to a major hiatus, with the lower succession dated as early Eocene to earliest early Oligocene (see "Biostratigraphy"). If the clays present in this interval are of detrital origin, the abundance of smectite and kaolinite indicates chemical weathering under warm and humid conditions. Similar clay assemblages previously have been observed in late Paleocene and early Eocene cores in the Southern Ocean (Robert and Chamley, 1991; Robert and Kennett, 1992, 1994). The presence of highly crystalline smectite in some samples from this lower section of Hole U1356A, however, may indicate that there is an authigenic component to the clay mineral assemblages in this interval. The relative proportion of detrital versus authigenic clay components will need to be examined more closely in postcruise analysis.

\section{Biostratigraphy}

Samples 318-U1356A-1R-CC through 106R-CC (0$1000.08 \mathrm{mbsf}$ ) and selected samples from cores were analyzed for microfossils. Siliceous microfossils (diatoms, radiolarians, silicoflagellates, ebridians, actiniscidians, chrysophyte cysts, and sponge spicules), palynomorphs (e.g., dinocysts, spores, and pollen), planktonic and benthic foraminifers, and calcareous nannofossils are present in various parts of cores from Hole U1356A.

A lower Eocene through lower upper Miocene sedimentary succession was recovered from Hole U1356A. In addition, the upper two sections of Core 318U1356A-1R represent a $\sim 3 \mathrm{~m}$ thick uppermost Miocene-lowermost Pliocene sedimentary drape. The results are summarized in Tables T3, T4, T5, T6, T7, and T8. Magnetostratigraphy and biostratigraphy are in good agreement (see "Paleomagnetism"). All index events (biostratigraphic and magnetostratigraphic) are compiled in Table T9. An integrated age-depth model for Hole U1356A is presented in Figure F4.

Siliceous microfossils are abundant and well preserved in the uppermost lower Miocene through lower upper Miocene interval (318-U1356A-1R-1, 3-5 cm, through 41R-CC; 0-387.00 mbsf) (Tables T3, T4). Although no biogenic opal is preserved below the uppermost lower Miocene in Hole U1356A (Cores
318-U1356A-42R through 106R; below $387.00 \mathrm{mbsf}$ ), it is commonly replaced by pyrite in the interval from Core 42R to the Eocene-Oligocene break between Cores 94R and 95R. Abundant to rare calcareous nannofossils occur throughout the Oligocene sediments (Cores 46R through 94R) (Tables T5, T6). Palynomorphs are recorded in nearly all samples investigated (Table T7). Their preservation varies between poor and good and is at least moderate in most samples. Planktonic and benthic foraminifers are absent above the uppermost lower Miocene ( 422.06 mbsf). They occur sporadically in the lower Miocene to lowermost Oligocene interval, typically as low-abundance, low-diversity assemblages, with agglutinated forms dominating. Foraminifers are recorded in most lower and middle Eocene samples (below 886.94 mbsf) (Table T8). Agglutinated forms dominate (typically $90 \%$ or more of the foraminifer assemblage), whereas poorly preserved planktonic foraminifers are occasionally observed in extremely low abundances.

The different microfossil groups resolve a stratigraphy nearly exclusive of one another by depth in Hole U1356A. Diatoms and radiolarians provide a highresolution biostratigraphy for the upper $387.00 \mathrm{mbsf}$ (Cores 318-U1356A-1R through 41R; uppermost lower Miocene through lower upper Miocene and uppermost Miocene-lowermost Pliocene) (Tables T3, T4, T9). Calcareous nannofossils, foraminifers, and, to a lesser extent, dinocysts resolve the interval between Cores 318-U1356A-46R and 92R ( 434.50 and 875.12 mbsf; Oligocene) (Tables T5, T6, T9). Dinocysts provide the only microfossil-based age control between $\sim 895.50$ and 995.32 mbsf (Cores 91R through 105R; lower Eocene and Oligocene) (Tables T7, T9).

Diatoms and radiolarians suggest that the Pleistocene and all but the lowermost of the Pliocene (i.e., 0 to $\sim 4.74 \mathrm{Ma}$ ) is missing in Hole U1356A. Some core disturbance must be taken into account, making interpretation of the upper 2-3 mbsf of the core problematic. Diatoms and radiolarians also suggest a hiatus at $\sim 3$ mbsf (between Samples 318-U1356A-1R2, 138-139 cm, and 1R-CC, coinciding with a sharp color change at $1 \mathrm{R}-2,140 \mathrm{~cm}$ ), which indicates that the latest Miocene (9.5-4.74/5.5 Ma) is also missing (Fig. F4; Table T9). A thick $(\sim 430 \mathrm{~m})$ continuous uppermost lower Miocene and middle Miocene through lower upper Miocene (17.0 to 9.5 Ma) biosiliceous sedimentary succession is defined at high resolution by diatoms and radiolarians to $387.00 \mathrm{mbsf}$. A hiatus or condensed interval from upper lower Miocene through uppermost Oligocene is suggested by calcareous nannofossils and magnetostratigraphy and appears to be associated with unconformity WLU5 ( 433-445 mbsf) (Fig. F4). The maximum duration 
of this hiatus or condensed interval is estimated as $\sim 5.62$ m.y. between 17.5 and 23.12 Ma. However, detailed study is required to resolve uncertainties resulting from reworking and limited biostratigraphic data. A thick $(\sim 460 \mathrm{~m})$ Oligocene sequence is currently constrained by magnetostratigraphy (see "Paleomagnetism") and partially by dinocyst and calcareous nannofossil data. The Oligocene/Miocene boundary is not preserved in Hole U1356A (Fig. F4).

The early middle Eocene to earliest Oligocene is missing in a long hiatus at $~ 893$ mbsf spanning 47.9 to $33.6 \mathrm{Ma}$ based on dinocyst evidence. This $\sim 14$ m.y. hiatus is closely associated with unconformity WL-U3 (Fig. F4). The oldest break in sedimentation occurs in lower Eocene strata between Sample 318-U1356A-101R-1, $100 \mathrm{~cm}$, and 100R-1, $100 \mathrm{~cm}$ (949.80-940.60 mbsf), based on magnetostratigraphy and the last occurrence (LO; highest stratigraphic occurrence) of Dracodinium waipawaense at 100R-1, 75-76 cm (see also "Paleomagnetism"). The base of Hole U1356A (1000.08 mbsf) is dated at $\sim 53.8$ Ma based on dinocyst and magnetostratigraphic data and shows that the Eocene succession recovered in Hole U1356A is 107 m thick.

Reworking of all microfossil groups occurs throughout the post-Eocene sedimentary succession in Hole U1356A. Conspicuously, palynomorphs derived from upper middle Eocene strata are abundantly reworked into lower Oligocene sediments.

\section{Siliceous microfossils}

Cores 318-U1356A-1R through 39R and 41R (387.00 mbsf) contain well-preserved and abundant biogenic silica (opal-A) dominated by diatoms and radiolarians, with variable abundances of silicoflagellates, ebridians, actiniscidians, chrysophyte cysts, and sponge spicules (Table T3). The diatom biostratigraphy provides primary age control in this biosiliceous sedimentary section. Radiolarians provide secondary age control that is in agreement with the diatom data.

Opal-A is not preserved in Core 40R (375.82 mbsf) and between Core 42R and the bottom of Hole U1356A (Sample 318-U1356A-106R-CC; 1000.08 mbsf). However, pyritized whole and fragmented siliceous microfossils are consistently present throughout Hole U1356A (noted from analysis of microscope slides prepared for palynology) and are relatively more abundant below the level of opal preservation.

\section{Diatoms}

A characteristic open-water Neogene Southern Ocean diatom flora was encountered in all samples analyzed through the biosiliceous-rich sedimentary interval (i.e., above $387.00 \mathrm{mbsf}$ ). Diatoms are abundant to few (Table T3), according to the categories outlined in "Biostratigraphy" in the "Methods" chapter.

Samples 318-U1356A-1R-1, 3-5 cm; 1R-2, 2-4 cm; and $1 \mathrm{R}-2,138-139 \mathrm{~cm}$ (0.03 to $2.89 \mathrm{mbsf})$, contain a well-preserved, common to abundant latest Miocene to earliest Pliocene diatom assemblage with minor reworked middle Miocene diatoms. The presence of Thalassiosira inura, Thalassiosira torokina, and Thalassiosira oliverana in the absence of other middle to late Pliocene index species such as Fragilariopsis barronii and Thalassiosira complicata (Table T3) suggest that these three samples be assigned to the earliest Pliocene, older than the first occurrence (FO; lowest stratigraphic occurrence) of $F$. barronii $(4.4 \mathrm{Ma})$ and younger than the FO for T. inura (4.74 Ma). However, the common occurrence of Denticulopsis simonsenii (Table T3) in these upper samples indicates that the LO of D. simonsenii $(4.89 \mathrm{Ma})$ is lost from the core top, supporting an earlier FO of T. inura (e.g., 5.5 Ma as identified by Winter and Iwai, 2002) and a somewhat older age for the section. Further, the presence of Actinocyclus actinochilus (first appearance datum [FAD] 2.81-2.72 Ma; see "Biostratigraphy" in the "Methods" chapter) in Cores 318-U1356A-1R and 2R also indicates some core disturbance by rotary drilling that must be taken into account.

A clear succession of index species (e.g., Cody et al., 2008) was recognized through the uppermost lower Miocene through lower upper Miocene interval (Fig. F4; Table T9). This allows assignment of Samples 318-U1356A-1R-CC through 7R-CC (4.60-57.04 mbsf) to the lower upper Miocene, Samples 8R-CC through 39R-CC (66.57-366.25 mbsf) to the middle Miocene, and Sample 41R-CC (387.00 mbsf) to the uppermost lower Miocene.

\section{Lower upper Miocene}

Twelve diatom datums were recognized between Samples 318-U1356A-1R-CC and 7R-CC (4.60-57.04 mbsf) (Table T9):

- FO and LO of

- Denticulopsis dimorpha var. areolata (10.31 and $10.25 \mathrm{Ma}$, respectively) and

- Denticulopsis ovata (11.09 and 9.64 Ma, respectively);

- FOs of

- Thalassiothrix miocenica (10.14 Ma),

- T. torokina (7.23 Ma),

- Rouxia peragalli (7.00 Ma),

- T. oliverana (6.18 Ma),

- T. inura (4.74 Ma),

- Rouxia californica (8.62 Ma),

- Fragilariopsis clementia (7.03 Ma); and

- LO of D. dimorpha (10.28 Ma). 
Diatoms suggest a hiatus at $\sim 3$ mbsf (between Samples 318-U1356A-1R-2, 138-139 cm, and 1R-CC, coinciding with sharp color change at 1R-2, $140 \mathrm{~cm}$ ), which indicates that the upper upper Miocene (4.74/ 5.5-9.5 Ma) is missing (Fig. F4). A linear sedimentation rate of $37 \mathrm{~m} / \mathrm{m} . \mathrm{y}$. is inferred for the mid-middle missing lower upper Miocene interval (Fig. F4). We use this sedimentation rate to infer the position of the middle/late Miocene boundary (11.61 Ma) between Samples 318-U1356A-7R-CC and 8R-CC (57.04$66.57 \mathrm{mbsf})$.

\section{Middle Miocene}

Ten diatom datums were recognized between Samples 318-U1356A-8R-CC and 39R-CC (Table T9):

- FOs of

- Actinocyclus ingens (15.87 Ma),

- Denticulopsis lauta (15.69 Ma),

- A. ingens var. nodus (14.60 Ma),

- Eucampia antarctica (10.46 Ma),

- D. simonsenii (14.16 Ma),

- Nitzschia denticuloides (13.49 Ma),

- Denticulopsis praedimorpha (12.97 Ma), and

- D. dimorpha (12.50 Ma); and

- LOs of

- Cavitatus jouseanus (14.47 Ma) and

- Denticulopsis maccollumii (14.33 Ma).

No major hiatuses are inferred in the mid-middle to upper lower Miocene interval with a linear sedimentation rate of $67 \mathrm{~m} / \mathrm{m}$.y. (Fig. F4). The early/middle Miocene boundary (15.97 Ma) is inferred between Cores 318-U1356A-38R and 41R (354.05-387.00 mbsf).

\section{Lower Miocene, Oligocene, and middle and lower Eocene}

The base of opal preservation ( 387.00 mbsf) is close to the FO of D. maccollumii (17.01 Ma) in the uppermost lower Miocene (Table T9). Below this, pyritized siliceous microfossils are generally abundant in the Oligocene through lower Eocene sedimentary interval. In five samples (Samples 318-U1356A-76R-5, $87 \mathrm{~cm}$; 76R-CC; 79R-CC; 87R-CC; and 89R-CC, some of which are those prepared for palynology) (Table T7), pyritized specimens are very abundant and are useful for age control and paleoenvironmental reconstruction in conjunction with palynomorph data. Their presence indicates prolific production and synsedimentary diagenesis in a restricted circulation (low oxygen) environment.

The most commonly pyritized diatoms are Pyxilla spp., Hemiaulus spp., and stephanopyxids. In some samples, index taxa are recognized, for example, the presence in Sample 318-U1356A-87R-CC of pyritized specimens of Cestodiscus spp. (common), Hemiaulus caracteristicus (trace), and Skeletonemopsis barbadense (trace) in association with abundant pyritized stephanopyxids and Pyxilla spp. indicates a late Eocene to early Oligocene age. This age assignment is partly in agreement with dinocyst and paleomagnetic data and is primarily based on unpublished siliceous microfossil range data from Ocean Drilling Program (ODP) Leg 189 Hole 1172A (C.E. Stickley, pers. comm., 2010), Leg 177 Hole 1090B (S.M. Bohaty and C.E. Stickley, pers. comm., 2010), and Leg 113 Hole 689B (S.M. Bohaty and D.M. Harwood, pers. comm., 2010).

One complete opaline specimen of the upper Oligocene-lower Miocene index diatom Rocella gelida was recorded in Sample 318-U1356A-49R-CC ( $\sim 60.00 \mathrm{mbsf}$ ). The current age model, as defined by calcareous microfossils and magnetostratigraphy (Fig. F4), indicate that this specimen is in situ.

\section{Radiolarians}

Radiolarians occur in variable abundances throughout Hole U1356A (Table T4). They are well preserved to moderately well preserved from Sample 318U1356A-1R-1, 3-5 cm, through 39R-CC (0.03$366.25 \mathrm{mbsf})$. Sample 40R-CC (375.82 mbsf) contains only a few recrystallized radiolarians, whereas Sample 41R-CC (387.00 mbsf) contains common and comparatively well preserved radiolarians. Preservation is poor and abundance is rare (or barren) in all samples below this level.

Samples 318-U1356A-1R-1, 3-5 cm (0.03 mbsf), and 1R-2, 2-4 cm (1.52 mbsf), contain Prunopyre titan (LO at $\sim 3.5 \mathrm{Ma}$ ) and Eucyrtidium pseudoinflatum (LO at $\sim 4.2 \mathrm{Ma}$ ) but lack Helotholus vema (2.3-4.2 Ma). The absence of Miocene radiolarians such as Acrosphaera australis (5.6-10.4 Ma) and Acrosphaera? labrata ( 5 to $7.8 \mathrm{Ma}$ ) provides an additional maximum age constraint that agrees with the diatom data, indicating that these two samples must be earliest Pliocene in age.

Acrosphaera australis is present in Sample 318-U1356A1R-CC (4.60 mbsf) but absent in samples below this level. The evolutionary ancestor to A. australis, Acrosphaera murrayana, co-occurs with Actinomma golownini (LO at $11.0 \mathrm{Ma}$ ) in Sample 318-U1356A-3R-CC (19.8 mbsf). The evolutionary transition of $A$. murrayana to $A$. australis $(10.4 \mathrm{Ma})$ therefore occurs within the interval between Samples 1R-CC and 3RCC (4.60-19.80 mbsf). Sample 11R-CC (98.66 mbsf) contains only few radiolarian specimens; therefore, the LO of Cycladophora spongothorax (12.6 Ma) likely falls between Samples 10R-CC and 12R-CC (85.89109.33 mbsf). 
The FOs of A. golownini (13.5 Ma) and Cycladophora humerus (14.1 Ma) fall within the interval between Samples 318-U1356A-14R-CC and 15R-CC (130.70$141.75 \mathrm{mbsf}$ ) and Samples 21R-CC and 22R-CC (193.85-203.95 mbsf), respectively (Table T9). The FO of Eucyrtidium punctatum (17.0 Ma) is recognized within Sample 41R-CC (387.00 mbsf), indicating an age younger than 17.0 Ma. However, Sample 41R-CC marks the lowermost sample from which radiolarians were recovered (and identifiable to species level); thus, the lower part of its range may be truncated in the barren interval. Hence, the given age should be regarded as a minimum age only.

\section{Silicoflagellates, ebridians, chrysophyte cysts, actiniscidians, and sponge spicules}

Above 387.00 mbsf (bottom of Sample 318-U1356A41R-CC), ebridians and sponge spicules occur in few to trace abundance, whereas silicoflagellates, actiniscidians, and chrysophyte cysts occur in trace abundance (Table T3). All groups exhibit good preservation.

\section{Calcareous nannofossils}

Calcareous nannofossils are abundant to rare between Cores 318-U1356A-47R and 94R (444.04-886.99 mbsf). Because they are the primary fossil group that helps resolve the Oligocene and Oligocene/Miocene boundary intervals for Site U1356, a series of light microscope images that captured the characteristics of the assemblage in each sample were e-mailed to a shore-based nannofossil scientist during the expedition. Preliminary data acquired during the expedition are presented in Table $\mathbf{T} 5$. In addition, selected samples were taken during the expedition for the purpose of refining Oligocene calcareous nannofossil biostratigraphy. The new calcareous nannofossil data collected immediately postcruise are presented in Table T6.

The LO of the index species Reticulofenestra bisecta occurs between Samples 318-U1356A-47R-3, 126-127 cm, and 47R-4, 31-32 cm (444.59 and $444.94 \mathrm{mbsf}$ ), and is placed in calcareous nannofossil Zone NP25 (Martini, 1971), correlating to magnetostratigraphic Chron C6Cn.2r (23.03-23.249 Ma). This is in agreement with magnetostratigraphy. Several specimens of $R$. bisecta occur in samples above this level but in low abundance and are therefore possibly reworked. According to Berggren et al. (1995), the LO of $R$. bisecta is $23.9 \mathrm{Ma}$, equivalent to $\sim 23.12 \mathrm{Ma}$ on the Gradstein et al. (2004) timescale, and approximating the Oligocene/Miocene boundary in the latest Oligocene.

The LO of Chiasmolithus altus, a Zone NP25 (Martini, 1971) marker, is identified between Samples 318-
U1356A-47R-CC and 48R-1, 6-7 cm (446.02$449.97 \mathrm{mbsf})$, correlating to Chron C8n (25.29526.154 Ma). Berggren et al. (1995) assign an age of 26.1 Ma for this event, which corresponds to $\sim 25.56 \mathrm{Ma}$ on the Gradstein et al. (2004) timescale, within the late Oligocene. However, magnetostratigraphy disagrees with this assignment, suggesting further work is necessary.

Magnetostratigraphy and the LO of $R$. bisecta define a latest Oligocene through late early Miocene hiatus or condensed interval $\sim 5.62$ m.y. in duration (17.5$23.12 \mathrm{Ma}$ ) in the 433-445 mbsf interval (Fig. F4).

The LO of Cyclicargolithus abisectus is placed between Samples 318-U1356A-78R-CC and 79R-1, 12-13 cm (744.11-747.13 mbsf), identifying Zone NP23 of the early Oligocene, between the top of Chron C11n.2n and base of C12r (29.853-33.266 Ma). However, we note the sporadic presence of specimens of $C$. abisectus above this interval (Table T6) with a size close to $11 \mu \mathrm{m}$, within the boundary of its taxonomic definition. However, we cannot discard reworking.

The LO of other biostratigraphically significant species such as Reticulofenestra umbilicus, Isthmolithus recurvus, and Chiasmolithus oamaruensis occurs between Samples 318-U1356A-93R-CC and 94R-4, 29$30 \mathrm{~cm}$ (880.72-885.93 mbsf). Particularly, the LO of $R$. umbilicus defines the limit between Zones NP22 and NP23 in the early Oligocene within late Chron C12r according to Berggren (1992) (from $~ 32$ to 31.116 Ma on the Gradstein et al., 2004, timescale). In addition, the $\mathrm{LO}$ of $I$. recurvus occurs within early Chron C12r according to Berggren (1992) ( 3233.266 Ma on the Gradstein et al., 2004, timescale).

The data suggest a thick Oligocene sequence of $\sim 460 \mathrm{~m}$ with an average linear sedimentation rate of $\sim 100 \mathrm{~m} / \mathrm{m} . \mathrm{y}$. for the uppermost Oligocene and $\sim 30 \mathrm{~m} / \mathrm{m}$.y. for the rest of the Oligocene (Fig. F4).

\section{Palynology}

Ninety-four samples from Hole U1356A were processed and analyzed for palynological content. The samples were predominantly taken from the core catcher material; from critical intervals, additional samples from the working half were examined. A list of all palynological samples from Hole U1356A is provided in Table T7. Nearly all samples from Hole U1356A yielded rich palynological associations, with palynomorph preservation ranging from poor to good. Generally, the palynological associations are dominated by marine palynomorphs (predominantly dinocysts). Sporomorphs are present in most samples, albeit in generally low abundance. Other palynomorphs (acritarchs and fungal spores) occur in trace amounts only. 


\section{Dinocysts}

Dinocysts are present in all samples. Their abundances vary between trace amounts (e.g., Sample 318-U1356A-92R-CC) to abundant (e.g., Sample 93RCC). Dinocyst preservation varies between poor and good; it is at least moderate in most samples. Selected dinocyst taxa are shown in Plates P1, P2, P3, P4, P5, P6, P7, P8, P9, P10, P11, and P12.

\section{Samples 318-U1356A-1R-CC through 93R-1, 15-17 cm (0-876.77 mbsf)}

From 0 to 876.77 mbsf, dinocyst assemblages are dominated by protoperidinioid taxa belonging to the genera Brigantedinium, Lejeunecysta, and Selenopemphix or related genera. At least six undescribed species of protoperidinioid dinocysts were identified, which will be formally described elsewhere.

The predominance of the cysts of protoperidinioid dinoflagellates, which are likely all heterotrophic, co-occurs with an abundance of pyritized diatoms recorded in this part of the succession. It suggests high sea-surface productivity, probably connected to sea ice ecosystems, akin to the modern Southern Ocean (e.g., Esper and Zonneveld, 2007).

Within two distinct intervals, one from Sample 318U1356A-39R-CC to 43R-CC (366.25-404.89 mbsf) and one from Sample 57R-CC to 59R-CC (538.18$556.73 \mathrm{mbsf}$ ), the protoperidinioid dinocyst assemblages are replaced by indicators of more oceanic, oligotrophic surface water conditions, such as Impagidinium spp., Nematosphaeropsis labyrinthus, and Batiacasphaera spp. In addition, the occurrence of lower latitude Impagidinium species suggests warming of the surface waters during these times. Based on the age model presented here for Hole U1356A, the two pulses correspond to ages of 18-16.5 and 22-21 Ma, respectively.

All samples contain reworked dinocysts characteristic of Eocene strata, such as Deflandrea antarctica, Deflandrea sp. A sensu Brinkhuis et al. (2003), Enneadocysta dictyostila, Vozzhennikovia apertura, and Vozzhennikovia stickleyae (Fig. F14; e.g., Brinkhuis et al., 2003). Specimens of these species are generally fragmented, bleached, and/or poorly preserved, which is in stark contrast to the good preservation of the protoperidinioid dinocysts within the same samples.

Given the composition of the dinocyst assemblages and the fact that most protoperidinioid taxa are stratigraphically long-ranging, the age control based on dinocysts is limited. Biostratigraphic age control comes mainly from diatoms and, to a lesser extent, from calcareous nannofossils and foraminifers. They suggest an early Oligocene to late Miocene/early Pliocene age for the succession between 0 and
886.00 mbsf. The diatom-based age information is supported by the range of Selenopemphix cf. armageddonensis from Samples 318-U1356A-1R-CC through 14R-CC (4.60-130.7 mbsf), the FO of Impagidinium patulum in Sample 318-U1356A-43R-CC (404.89 mbsf), and an isolated finding of Filisphaera filifera in Sample 318-U1356A-58R-CC (565.21 mbsf). Selenopemphix armageddonensis sensu stricto ranges from 5.4 to 9.0 $\mathrm{Ma}$ in the lower latitudes. Impagidinium patulum has a low-latitude FO at $16.2 \mathrm{Ma}$, and F. filifera has a northern mid-latitude first occurrence at $23.95 \mathrm{Ma}$ (see Tables T3, T4 in the "Methods" chapter for references on dinocyst event ages).

Despite the lack of stratigraphic Oligocene-Neogene index species, different members of the protoperidinioid assemblages indicate distinct bioevents. Notably, the first consistent occurrence of Brigantedinium spp. in Sample 318-U1356A-85R-CC (811.34 mbsf) and the LO of a (previously undescribed) large Lejeunecysta species ("Lejeunecysta large" in Table T7) in Sample 86R-CC (822.54 mbsf) may be of stratigraphic significance and may merit a more detailed analysis during future onshore work. The in-depth morphological/stratigraphical evaluation of the protoperidinioid assemblages during postcruise research may eventually yield additional stratigraphically important datums.

\section{Samples 318-U1356A-94R-CC through 93R-1, 15-17 cm (886.94-876.77 mbsf)}

This interval, which is characterized by slump features based on sedimentological observations (see "Lithostratigraphy"), contains late Eocene to late middle Eocene dinocysts. Notably, Sample 318U1356A-94R-CC (886.94 mbsf) contains abundant Lejeunecysta spp. and Selenopemphix spp. and is strongly reminiscent of the protoperidinioid-dominated assemblages characterizing the younger part of the succession.

Typical markers for the Eocene/Oligocene boundary interval (such as Stoveracysta kakanuensis and Stoveracysta ornata) were not found. Of particular importance is the presence of Forma $\mathrm{T}$ sensu Goodman and Ford, 1983, in Samples 91R-7, 64-65 cm, through 95R-3, 25-26 cm (869.76-894.12 mbsf). Goodman and Ford (1983) reported this taxon from DSDP Leg 71 Site 511 on the Falkland Plateau. There, its range has been suggested to be restricted to the early Oligocene based on nannofossil and dinocyst age control. Unpublished high-resolution investigations on dinocyst samples from Site 511 have shown that Forma T sensu Goodman and Ford, 1983, has its FO at 100 k.y. following Oligocene isotope Event 1 (Oi-1), at 33.6 Ma (A.J.P. Houben, pers. comm., 2010). Therefore, strata at Site U1356 above Sample 
318-U1356A-95R-3, 25-26 cm (894.12 mbsf), are considered to be 33.6 Ma or younger in age.

\section{Samples 318-U1356A-100R-CC through 95R-CC (939.85-891.97 mbsf)}

Conspicuously, the abundances of protoperidinioid dinocysts decline dramatically from Sample 95R-1, 97-100 cm (892.00 mbsf), downhole (Figs. F14, F15). Brigantedinium spp. are absent in this interval altogether, and Lejeunecysta spp. and Selenopemphix spp. are present in low numbers only. Instead, the dinocyst assemblages are characterized by the dominance of D. antarctica, Phthanoperidinium spp., and Spinidinium spp., all of which are characteristic of Eocene strata (e.g., Brinkhuis et al., 2003). The absence of members of the typical protoperidinioid assemblage as encountered higher in the core suggests that these Eocene dinocysts are in situ.

For the interval between Samples 318-U1356A100R-1, 75-76 cm, and 95R-1, 79-100 cm (939.86$892.00 \mathrm{mbsf}$ ), a number of biostratigraphic index species for the early to early middle Eocene are recorded. In alphabetical order, these markers include Apectodinium homomorphum, Arachnodinium antarcticum, Charlesdowniea coleothrypta, Charlesdowniea edwardsii, Hystrichokolpoma spinosa, and Membranophoridium perforatum.

The LO of $M$. perforatum between Samples 318U1356A-95R-3, 25-26 cm, and 95R-CC (894.12895.72 mbsf) suggests a minimum age of $47.9 \mathrm{Ma}$. The FO of C. edwardsii (in Sample 318-U1356A-95RCC; $895.72 \mathrm{mbsf}$ ) is $52.2 \mathrm{Ma}$ (see Tables T3, T4 in the "Methods" chapter for references). The LO of $A$. homomorphum (between Samples 318-U1356A-97R-CC and 96R-CC; 911.73-901.00 mbsf) has previously been reported to mark the early/middle Eocene boundary $(48.6 \mathrm{Ma})$ in the South Pacific Ocean. The FO of $A$. antarcticum (between Samples 318-U1356A97R-CC and 98R-1, 33-34 cm; 911.73-920.14 mbsf) is at $\sim 51.5 \mathrm{Ma}$. The FO of H. spinosa between Samples 318-U1356A-99R-CC, 30-35 cm, and 100R-1, 75$76 \mathrm{~cm}$, suggests a maximum age of $51.9 \mathrm{Ma}$ for the former sample (see Tables T3, T4 in the "Methods" chapter for references on ages of individual dinocyst events). The LO of $D$. waipawaense between Samples 318-U1356A-101R-CC and 100R-1, 75-76 cm (951.92$939.85 \mathrm{mbsf})$, suggests an age older than 52.6 Ma.

\section{Samples 318-U1356A-101R-CC through 106R-CC (951.9-1000.08 mbsf)}

The general dinocyst assemblage of this interval differs from the overlying interval by lower abundances of $D$. antarctica and the dominance of gonyaulacoid dinocysts such as Areoligera spp., Hystrichosphaeridium tubiferum, and Hystrichosphaeridium truswelliae.
Another common species within the dinocyst assemblage is Enneadocysta sp. A of Brinkhuis et al. (2003), which has been recorded in the mid-lower Eocene at Site 1172. The presence of D. waipawaense in Samples 318-U1356A-101R-CC through 106R-CC (951.97$1000.08 \mathrm{mbsf}$ ) confirms a mid-early Eocene age (53.3-52.6 Ma).

Of particular interest is the dominance of $A$. homomorphum within Sample 318-U1356A-105R-CC (955.32 mbsf). This tropical species has previously been shown to invade high-latitude environments only during the Paleocene/Eocene Thermal Maximum (PETM; 55.8 Ma) (Sluijs et al., 2007). Because Sample 318-U1356A-105R-CC has a mid-early Eocene age (based on the presence of D. waipawaense), it must be younger than the PETM. We therefore tentatively correlate Sample 318-U1356A-105R-CC to another Eocene hyperthermal phase, possibly the Eocene Thermal Maximum 2 or 3 (Cramer et al., 2003; Lourens et al., 2005; Nicolo et al., 2007). In this context, it is interesting to note that mid-early Eocene sections in New Zealand have also yielded horizons with abundant Apectodinium spp. (Crouch and Brinkhuis, 2005). Thus, they might be correlative with the acme of Apectodinium spp. in Sample 318-U1356A-105R-CC (955.32 mbsf). Dinocyst data indicate that $\sim 107 \mathrm{~m}$ of early Eocene and late early to earliest middle Eocene sediments are preserved in Hole U1356A, with an average sedimentation rate of $\sim 24 \mathrm{~m} / \mathrm{m}$.y. for the early Eocene (Fig. F4).

\section{Sporomorphs}

\section{Samples 318-U1356A-1R-CC through 94R-CC (0- 886.94 mbsf)}

From 0 to 892.00 mbsf, sporomorphs occur in nearly all samples investigated, albeit usually in low abundances. With the exception of pollen from Nothofagus, they are generally remarkably well preserved. The prevalence of thick-walled and/or particularly chemical-resistant taxa (as indicated by the strong representation of ferns and bisaccates, respectively), the degree of thermal alteration (as indicated by dark colors), and the previously established stratigraphic range of various taxa suggest that most, if not all, sporomorphs from the succession between 0 and 886.94 mbsf are reworked.

Sporomorphs reworked from Mesozoic strata include Callialasporites turbatus. A Mesozoic to early Paleogene age can be ascribed to Aquilapollis, Cicatricosisporites, Classopollis/Corollina, and Ischyosporites. Paleozoic (Devonian? to Permian) taxa comprise Triancoraesporites and Taeniaesporites. Although Nothofagus is an extant taxon, the Nothofagus pollen grains found between 0 and 886 mbsf are likely reworked. The oldest pollen assemblages containing 
Nothofagus are known from the late Campanian (71 Ma). However, based on a comparison with the (poorly preserved) dinocysts of Eocene age and the (well preserved) sporomorphs from the Mesozoic, we tentatively suggest that the Nothofagus pollen grains observed in Samples 1R-CC through 94R-CC are reworked from Eocene strata. Selected sporomorphs are shown in Plate P12.

\section{Samples 318-U1356A-106R-CC to 95R-1, 97-100 cm (1000.08-891.97 mbsf)}

From 1000.08 to 891.97 mbsf, sporomorphs are present in all samples investigated (Cores 318-U1356A106R through 95R), with generally higher abundances than further up in the succession. Sporomorph assemblages are characterized by well-preserved Nothofagus pollen grains, bisaccates, and spores. No indications of reworking have been found.

\section{Other palynofacies components}

All samples contain palynofacies components other than dinocysts and sporomorphs. Acritarchs, foraminifer test linings, and fungal spores occur in trace amounts in various samples. Black and brown phytoclasts are recorded commonly in all samples. Amorphous organic matter, in contrast, is encountered in trace amounts in most samples; it increases in abundance downhole from Sample 318-U1356A-91R-1, 32-34 cm (862.64 mbsf).

\section{Foraminifers}

\section{Planktonic foraminifers}

Shipboard examination of all core catcher samples yielded sporadic occurrences of planktonic foraminifers from Core 318-U1356A-34R downhole (Table T8). However, the assemblages are poorly preserved and low in abundance and diversity. This is likely a combination of thin shells and corrosive bottom waters. In addition, downslope processes also likely resulted in reworking of foraminifers in some samples. This includes the specimens identified in Samples 318U1356A-46R-CC and 45R-CC (434.71-422.32 mbsf), in which poorly preserved and heavily recrystallized planktonic foraminifers of Oligocene age were identified (i.e., Globigerina euapertura and Globigerina labiacrassata). This is supported by the presence of abundant fine to medium quartz sands in these samples, interpreted to be turbidite deposits (see "Lithostratigraphy"). In contrast, a low-abundance, low-diversity assemblage identified in Sample 318U1356A-50R-CC (469.92 mbsf) contains planktonic foraminifers interpreted to be in situ, based on the lack of coarser grained sediments, which would have suggested deposition by turbidity currents. The co- occurrence of Catapsydrax dissimilis and Globigerina connecta provides an age constraint for this interval of older than 17.15 Ma and younger than 21.5 Ma. Finally, the occurrence of Acarinina wilcoxensis in Sample 318-U1356A-106R-CC (1000.08 mbsf) constrains the age of these sediments to between 55.55 and 51.70 Ma.

\section{Benthic foraminifers}

Benthic foraminifers are absent above Sample 318U1356A-45R-CC (422.32 mbsf), below which they occur sporadically downhole to Sample 318-U1356A90R-CC (852.90 mbsf). From this sample to the top of the Eocene section, they are present in samples not associated with turbidite or debris flow deposition. Where present, benthic foraminifer assemblages are generally dominated by agglutinated forms, often with low abundances (generally $<20$ specimens).

Twelve species were identified between Samples 318U1356A-46R-CC and 45R-CC (434.71 and $422.32 \mathrm{mbsf}$ ), including species of the genera Cibicidoides, Fissurina, Gyroidinoides, Melonis, Oolina, Pyrulina, and Stilostomella as well as several agglutinated forms. One specimen of Melonis sphaeroides was present; this species indicates lower bathyal to abyssal depths (Loeblich and Tappan, 1988). Several apparently reworked planktonic foraminifers were observed in this sample, suggesting that the benthic foraminifers may have also been transported downward from higher on the rise. This is supported by the presence of fine to coarse sands in the sediments washed from this sample, which are interpreted as a turbidite deposit (see "Lithostratigraphy").

The upper Oligocene section is mainly barren of foraminifers, with only occasional occurrences, typically numbering $<10$ specimens per sample. The best-preserved benthic foraminifer assemblage in the Oligocene interval occurs in Sample 318-U1356A73R-CC (695.81 mbsf) and is relatively diverse (16 species, 54 specimens). It is dominated by agglutinated types (62\% of the total assemblage), such as Cyclammina pusilla, Bathysiphon discreta, and Jaculella acuata. Globocassidulina subglobosa, Dentalina advena, and Rectuvigerina stonei are calcareous types, suggesting a generally abyssal to lower bathyal environment. This assemblage is similar to those from other studies from abyssal sites off Antarctica, in which the first downhole occurrences (stratigraphic LOs) of in situ foraminifers are recorded from the early Miocene and late Oligocene (Rögl, 1976; Barker, Kennett, et al., 1988).

Benthic foraminifers occur in most Eocene samples deeper than Sample 318-U1356A-90R-CC (deeper than $852.90 \mathrm{mbsf}$ ) not associated with slumping or 
turbidites. Agglutinated species dominate the assemblage, with Ammodiscus glabrans, Psammosphaera fusca, Rhabdammina linearis, Bathysiphon spp., J. acuata, and Reophax spp. Calcareous forms are generally rare, typically only a few specimens were observed per sample. These taxa have been found in abyssal water depths off Antarctica in Paleogene through lower Neogene cores (Rögl, 1976).

\section{Age model, sedimentation rates, and paleoenvironmental interpretation}

In this section, we summarize the biostratigraphic and paleoenvironmental interpretation inferred from the individual microfossil groups described above. The integrated age-depth model presented in Table T9 and Figure F4 also incorporates the magnetostratigraphic age constraints (see "Paleomagnetism").

\section{Age model and sedimentation rates}

Diatoms resolve the biosiliceous sedimentary sequence in the upper $387.00 \mathrm{~m}$ of Hole U1356A (Cores 318-U1356A-1R through 38R and 41R) at high resolution. They indicate deposition of lower upper Miocene through uppermost lower Miocene sediments at relatively high linear sedimentation rates of $37 \mathrm{~m} / \mathrm{m} . \mathrm{y}$. for the lower upper Miocene through mid-middle Miocene interval ( 9.5-14 Ma), increasing to $67 \mathrm{~m} / \mathrm{m}$.y. for the mid-middle Miocene through uppermost lower Miocene ( 14-17 Ma) (Fig. F4). The age model suggests that the Miocene interval is $\sim 430 \mathrm{~m}$ thick in Hole U1356A. Based on linear sedimentation rates the middle/late Miocene boundary (11.61 Ma) occurs between 57.04 and $66.57 \mathrm{mbsf}$ and the early/middle Miocene boundary (15.97 Ma) occurs between 354.05 and 387.00 mbsf. Reworking of early Paleogene, Mesozoic, and Paleozoic material is moderate to high. A sedimentary drape of earliest Pliocene to latest Miocene is inferred in the top few meters of the hole.

Calcareous nannofossils, foraminifers, and dinocysts resolve the interval below $387.00 \mathrm{mbsf}$ to the bottom of the hole (1000.08 mbsf), suggesting deposition of uppermost Oligocene sediments at a sedimentation rate of $\sim 100 \mathrm{~m} / \mathrm{m}$.y. and lower to uppermost Oligocene sediments at a rate of $\sim 30 \mathrm{~m} / \mathrm{m}$.y. A latest Oligocene to late early Miocene hiatus or condensed interval between 23.12 and $17.5 \mathrm{Ma}$ is placed between 433 and 445 mbsf based on calcareous nannofossil and magnetostratigraphic data.

A long hiatus from 47.9 to $33.6 \mathrm{Ma}$ at $\sim 890 \mathrm{mbsf}$ indicates that the earliest stages of the EoceneOligocene transition are not recovered in Hole U1356A but that $\sim 100$ k.y. post-Oi-1 sediments are preserved. This information indicates that the Oligo- cene strata are $\sim 460 \mathrm{~m}$ thick and the lower Eocene to lower middle Eocene is $\sim 107 \mathrm{~m}$ thick in Hole U1356A. Lower Eocene deposition occurred at a sedimentation rate of on average $\sim 24 \mathrm{~m} / \mathrm{m}$.y., although we acknowledge this carries a high error due to poor core recovery. The base of Hole U1356A is $\sim 53.8 \mathrm{Ma}$ based on magnetostratigraphic data (Fig. F4).

\section{Paleoenvironmental interpretation}

Organic microfossil-rich sediments were deposited at Site U1356 during early to middle Eocene times. Based on the high dinocyst species diversity and notably the abundance of Spiniferites spp., the dinocyst assemblages typically reflect outer shelf facies. This is much shallower than that inferred from the Oligocene and Miocene microfossil assemblages, which typically reflect oceanic settings. This discrepancy implies that a deepening event, or events, occurred during the middle to late Eocene. The lack of siliceous microfossils in the Eocene in Hole U1356A also suggests a very shallow water, restricted environment.

Dinocysts are associated with abundant pyritized siliceous microfossils and nannofossils in Oligocene and lower Miocene sediments, which indicates a nutrient-rich pelagic setting during the Oligocene to early Miocene. The abundance of pyrite and absence of opal suggests reduced oxygen conditions below the sediment/water interface.

Latest early Miocene to early late Miocene (and Pliocene) siliceous microfossil assemblages are dominated by open-marine pelagic taxa with low abundances of benthic, neritic, or sea ice-associated taxa, which implies that during this time biosiliceous-rich sediments were deposited in an open, well-ventilated, nutrient-rich, pelagic-marine setting (at relatively high sedimentation rates of 37-67 m/m.y.). Considering this, the most likely explanation for the absence of latest Miocene and late early Pliocene to Holocene sediments at Site U1356 is strong current erosion and/or mass flow erosion. Further, the preservation of opal from the late early Miocene $(\sim 17 \mathrm{Ma})$ onward may indicate a switch in deepwater circulation patterns from a poorly oxygenated lowsilica system (early to early middle Eocene to late early Miocene) to a well-ventilated, silica-enriched system akin to the modern Southern Ocean.

\section{Paleomagnetism}

\section{Methods and instruments}

Archive-half cores were measured on the $2 \mathrm{G}$ Enterprises cryogenic magnetometer and demagnetized at $20 \mathrm{mT}$. Generally, one section per core was also demagnetized at 5, 10, and $15 \mathrm{mT}$ prior to the $20 \mathrm{mT}$ 
step. The anisotropy of magnetic susceptibility (AMS) and bulk susceptibility were measured on all discrete samples, typically one per core section. Selected samples were also analyzed using step-wise alternating-field demagnetization on either the cryogenic or spinner magnetometers.

\section{Results}

All paleomagnetic measurements from archive halves are shown in Figure F16. The quality of these data can be assessed by:

1. Examining the sedimentary fabrics using the AMS data,

2. Examining the high-resolution core photographs and sedimentary logs for evidence of drilling or sedimentary disturbance of the core material,

3. Examining the behavior of the sediments during progressive demagnetization, and

4. Comparing the inclinations observed with those expected from paleosecular variation at this latitude.

We plot all susceptibility data from the discrete samples in Figure F17. Sedimentary fabrics are expected to be oblate with indistinguishable intermediate and maximum eigenvalues (triangles and squares, respectively, in Fig. F17A) and vertical axes of minimum susceptibility (inclinations of the $\mathrm{V}_{3}$ eigenvector shown in Fig. F17B). The AMS data from the top few cores have virtually indistinguishable eigenvalues (they are isotropic) and the $\mathrm{V}_{3}$ eigenvectors are strongly deviated from the vertical. These samples suffer from drilling disturbance, and no reliable paleomagnetic data can be derived from them. However, the AMS data of Core 318-U1356A-14R (130 mbsf) and below are similar to those expected for a primary sedimentary fabric. Note also that bulk susceptibility measurements (Fig. F17C) are calibrated volume susceptibilities and could be used to calibrate the whole-core magnetic susceptibility data.

We inspected each core section using digitally enhanced photographs (see example in Fig. F18). The gray portion of the paleomagnetic data in this example was deleted because of the evident microfaulting (e.g., Fig. F18D) and contorted bedding (e.g., Fig. F18E). The lower portion of the core suffered only minor core breaks (e.g., Fig. F18F) and therefore was considered reasonably undisturbed. Fortunately, at high latitude rotations round the vertical axis only result in offsets in declination (e.g., at $\sim 50 \mathrm{~cm}$ in Fig. F18B) but do not affect our ability to discriminate polarity, which is based solely on the inclination. Other types of core disturbance (e.g., from the drilling process or from slumping) were also edited out. The remaining data, after demagnetization at $20 \mathrm{mT}$, are shown in Figure F16 (black circles).
Progressive demagnetization data can be used to assess whether the samples are stably magnetized or have unremoved drilling-induced overprints. We carried out progressive demagnetization on all archive halves as well as selected discrete samples (see examples in Fig. F19). The behavior of the discrete samples and archive-half sections was similar (compare Fig. F19A, F19C from discrete samples with Fig. F19B, F19D from archive halves). The normally magnetized sediments (Fig. F19A, F19B) exhibit the behavior characteristic of removing a steeply downward directed overprint, likely the drill string overprint. In the reversely magnetized sediments, the steep downward direction is also removed, but the effect is more subtle. In most cases, the drill string overprint was removed by 15 or $20 \mathrm{mT}$, and we feel reasonably confident that the directions derived by demagnetizing the archives to $20 \mathrm{mT}$ in most cases represent true polarity.

Finally, we compare the observed inclinations with those expected at the site latitude in the Eocene $\left(\sim 60^{\circ} \mathrm{S}\right.$ latitude) from the statistical model of paleosecular variation of Tauxe and Kent (2004). We plot the inclinations of the natural remanent magnetizations from archive measurements (after editing out disturbed portions of the core) in Figure F20A. After demagnetization at $20 \mathrm{mT}$, the two polarity groups of normal and reverse inclinations become much more distinct (Fig. F20B). The expected distribution of inclinations from the statistical model of paleosecular variation is shown in Figure F20C. The data from the archive section half measurements are biased toward shallow inclinations compared to the field model, an effect commonly observed in sediments, particularly ones as compacted as those considered here. The clear separation of inclinations into two modes, however, means that our interpretations of polarity are reasonably robust, except for cases of shallow inclination.

\section{Correlation to the geomagnetic polarity timescale}

Three intervals with sufficiently continuous recovery make a correlation to the GPTS possible (Fig. F21; Table T1) with constraints provided by biostratigraphic identifications (see "Biostratigraphy").

The top portion (Fig. F21A), spanning Cores 318U1356A-14R through 51R, correlates to polarity Chrons C5AAn to C5Dn. The polarity stratigraphy from Cores 46R through 51R does not have a straight forward fit to the GPTS, so a hiatus could be placed between Cores 46R and 47R. The reversal within Core 47R could correspond with Chron C6Cn.2n(y), according to nannofossil constraints (see "Biostratigraphy"). 
Cores 318-U1356A-68R through 92R correlate to polarity Chrons C7An to C12r. Cores 78R and 79R have scattered directions. Examination of the progressive demagnetization curves from this interval suggests that these cores could have incompletely removed drill string overprints on normal polarity intervals. If true, this interval may correspond to Chron C10n. Shore-based demagnetization studies are necessary to confirm this suspicion. Core 92R has some apparently normal directions in it and the correlation of directions is unclear. Many cryptochrons are identified in Chron C12r (e.g., Cande and Kent, 1992) and it is possible that these directions correspond to one of the cryptochrons.

The failure to recover undisturbed sediments from Cores 318-U1356A-94R through 97R preclude interpretation of the magnetostratigraphy. Recovery improved below these cores, and the portion spanning Cores 98R through 106R is shown in Figure F21C. Starting from the bottom, the lowermost normal polarity interval in Core 105R and the top part of 106R corresponds to Chron C24n.3n. Core 104R is dominantly reverse with a short normal interval correlating to Chron C24n.2n. The top of Core 104R and all of Core 103R record Chron C24n.1n. Core 102R has a reverse magnetization and fits comfortably within Chron C23r, and the bottom of Core 101R could record the base of Chron C23n.2n. However, the correlation of Cores 100R through 98R is not straight forward. Cores $100 \mathrm{R}$ and $99 \mathrm{R}$ have mostly reverse magnetizations, whereas Chron C23n.2n is normal. The transition recorded at the base of Core 101R correlates to Chron $23 n .2 n$, consistent with a constant sedimentation rate model and available biostratigraphic constraints. Extrapolating upward from the base of Chron C24n, there must be a hiatus between the bottom of Core 101R and 100R. The smallest gap, consistent with biostratigraphic constraints (see "Biostratigraphy"), would place the transition recorded in Core 99R at the base of Chron 23.1n. Core 100R would then be Chron C23n.1r in age. The duration of the hiatus under this interpretation would be at least 0.9 m.y. The top of Chron C23n is recorded in Core 98R.

\section{Geochemistry and microbiology Organic geochemistry}

\section{Volatiles}

Methane and gas analysis was performed typically once per core using the methods described in the "Geochemistry and microbiology" in the "Methods" chapter.

Methane concentrations varied by four orders of magnitude downhole from undetected to $>10,000 \mathrm{ppmv}$
(Fig. F22). Levels are low between 0 and $200 \mathrm{~m}$, increasing to between 1000 and 6000 ppmv between 300 and 1000 mbsf, with two spikes at 600 and 690 mbsf. $C_{1} / C_{2}$ levels were high throughout the hole and indicated no threat to drilling operations.

\section{Assay of organic biomarkers}

Twenty-five samples from Site U1356, ranging in age from early Eocene to late Miocene, were taken for extraction of lipids. Details of the methods are given in the "Geochemistry and microbiology" in the "Methods" chapter. One advantage of the methodology employed is the production of six chemical fractions for separation and clean-up of the different biomarker groups of principal utility for paleoceanographic and environmental reconstructions. The six fractions comprised aliphatic hydrocarbons, hopanes, and unidentified complex mixtures of branched alkanes (N1); polyaromatic hydrocarbons (N2); ketones (including alkenones) and aldehydes (N3); $n$-alkanols, sterols, and diols (N4); and $n$ alkanoic acid methyl esters (FAMES). The presence and concentrations of the high-utility tetraethers could not be determined on board because the chemistry laboratory is not presently equipped with a liquid chromatography-atmospheric pressure chemical ionization-mass spectrometry (LC-APCI-MS) device. We expect the tetraethers to elute in the N4 fraction, which will be measured on shore by LCAPCI-MS. Moreover, to ensure that the tetraethers were fully recovered, the silica gel columns (see "Geochemistry and microbiology" in the "Methods" chapter) were flushed with methanol and an additional fraction containing the most polar compounds (and any tetraethers not eluting in N4) was collected (N5 fraction).

The N1, N3, N4, and FAMES fractions were analyzed by gas chromatography mass spectrometry (GC-MS), and the results from each fraction are summarized in Tables T10, T11, T12, and T13, respectively (the N2 and N5 fractions were archived). Examples of GC-MS total- and single-ion chromatograms (of the four analyzed fractions) from four samples are presented in Figures F23 (middle Miocene), F24 (late Oligocene), F25, and F26 (both early Eocene). The primary purpose of this section is to ascertain biomarker composition and concentrations to aid the focus and priorities of future shore-based organic geochemical work. In particular, we wish to determine which compounds are present in sufficient concentration and with sufficient resolution (i.e., clean isolated peaks) for subsequent compound-specific isotope analysis for $\delta^{13} \mathrm{C}$ and $\delta \mathrm{D}$. Current analytical requirements are $\sim 10 \mathrm{ng}$ per GC peak (in duplicate) for $\delta^{13} \mathrm{C}$ and $\sim 100 \mathrm{ng}$ per $\mathrm{GC}$ peak (in triplicate) for $\delta \mathrm{D}$ analyses. 


\section{N1 fraction}

Homologous series of higher molecular weight (HMW) $n$-alkanes (along with $n$-alkanoic acids and $n$ alkanols) are synthesized by terrestrial higher plants as constituents of the epicuticular waxes and are some of the earliest biomarkers studied by science (Eglinton and Calvin, 1967; Eglinton and Hamilton, 1967). Low molecular weight (LMW) $n$-alkanes are much less indicative, being ubiquitous in cellular material and the primary constituents of oil and petroleum. Concentrations of HMW $n$-alkanes are low in the Miocene and Oligocene samples but increase in the early Eocene samples (Table T10). Fresh, higher plant HMW $n$-alkanes are characterized by a higher carbon preference index (CPI; a measure of the relative predominance of the compounds with odd-numbered carbon chains), whereas diagenetic, microbial, or crude oil $n$-alkanes are characterized by lower CPI values. When sufficiently abundant to be measured, the Eocene HMW $n$-alkanes are characterized by relatively high CPI values (Table T10). Figure F25 illustrates an example of thermally immature, higher plant wax $n$-alkanes from the Eocene. In contrast, Figure F24 shows an example of lower CPI $n$ alkanes, indicative of diagenetic or microbial source alkanes or contamination by petroleum byproducts.

A characteristic of the Eocene samples, which yield abundant higher plant $n$-alkanes, is the coeval presence of abundant hopane compounds derived from soil bacteria (Rohmer et al., 1984). Traditionally, hopanes and their precursor hopanoids have been attributed to aerobic bacteria, but recent work has revealed an anaerobic origin for hopanoids as well (Härtner et al., 2005). Moreover, their utility in paleoclimate studies has been recently highlighted by work that reports a decrease in the carbon isotope values of the hopanes extracted from the Cobham lignite (United Kingdom) at the onset of the PETM interval (Pancost et al., 2007). The isotopic excursion suggests an increase in the methanotroph population, reflecting an increase in methane production potentially driven by changes to a warmer, wetter climate. The presence of hopanes in the Eocene samples, along with abundant plant waxes ( $n$-alkanes and $n$-alkanoic acids) confirms significant inputs of thermally immature organic material to Site U1356 from proximal terrestrial environments during the Eocene.

\section{N3 fraction}

Alkenones are synthesized by a limited number of unicellular algae of the Haptophyta, which include the coccolithophorids and are often informally called haptophytes (Conte et al., 1994; Marlowe et al., 1984; Volkman et al., 1980). Alkenones have been studied extensively in the open ocean, where the temperature-dependent distribution of the $\mathrm{C}_{37: 2}$ and $\mathrm{C}_{37: 3}$ alkenones (as expressed in $\mathrm{Uk}_{37}{ }^{\prime}$ ) has been confirmed by culture, surface sediment, and water column particulate organic matter studies (e.g., Conte et al., 2006; Müller et al., 1998; Prahl and Wakeham, 1987).

Furthermore, alkenone $\delta^{13} \mathrm{C}$ has been used as a proxy for the estimation of past $p \mathrm{CO}_{2}$ levels (e.g., Pagani et al., 2002). At Site U1356, alkenones were found in the majority of samples from the Eocene (Table T11) and possibly one sample from the early Oligocene (the concentration is too weak for confident assignment). Superior sensitivity for the detection of alkenones was achieved by operating the GC-MS in single-ion monitoring mode. However, concentrations could only be reasonably estimated (by external standards) using scanning mode (Table T12). Only the $\mathrm{C}_{37: 2}, \mathrm{C}_{38: 2}$, and $\mathrm{C}_{39: 2}$ components were detected, suggesting either Eocene sea-surface temperatures during the alkenone production season at Site U1356 were $\geq 30^{\circ} \mathrm{C}$ and/or preferential degradation of the tri-unsaturated compounds. Concentrations of the alkenones suggest compound-specific $\delta^{13} \mathrm{C}$ measurements might be feasible on some early Eocene samples.

\section{N4 fraction}

High molecular weight alkanols are constituents of higher plant waxes, whereas LMW $n$-alkanols are indicative of nonspecific marine phytoplankton and zooplankton sources. Compared to the $n$-alkanes, and especially the $n$-alkanoic acids, the HMW $n$ alkanols were sparse at Site U1356; some were found in the Miocene and Eocene but in low concentrations. The LMW $n$-alkanols were detected in many samples and are noticeably more abundant in the Eocene.

Sterols are abundant components of lipid membrane in many organisms. The relative abundances of different sterols (Villinski et al., 2008) can be used to reconstruct changes in the productivity of different algal groups (e.g., dinosterol for dinoflagellates and brassicasterol for diatoms). Two samples from the Oligocene (Table T12) contained a suite of sterols, as well as the diatom-produced $\mathrm{C}_{28}$ diol. However, in other samples the nonspecific cholesterol (if present) was the only measurable sterol and no other sterols or diols were detected.

\section{FAMES fraction}

The LMW components of the $n$-alkanoic acids $\left(\mathrm{C}_{14}\right.$ $\left.\mathrm{C}_{23}\right)$, as with the $n$-alkanols $\left(\mathrm{C}_{15}-\mathrm{C}_{23}\right)$, are indicative of nonspecific marine phytoplankton and zooplankton sources, especially the $n-\mathrm{C}_{14}, n-\mathrm{C}_{16}$, and $n$ - $\mathrm{C}_{18}$ homologs 
(Gagosian et al., 1983). The HMW $n$-alkanoic acids $\left(\mathrm{C}_{24}-\mathrm{C}_{34}\right)$, along with the $n$-alkanes $\left(\mathrm{C}_{25}-\mathrm{C}_{35}\right)$ and $n$ alkanols $\left(\mathrm{C}_{24}-\mathrm{C}_{30}\right)$, are the major components of higher plant leaf waxes (Eglinton et al., 1962; Eglinton and Hamilton, 1967; Kolattukudy, 1976). At Site U1356, the HMW n-alkanoic acids occur as the most abundant higher plant biomarkers. Occurrence and concentrations are markedly higher in the Eocene samples than the Oligocene and Miocene (Table T13). Moreover, compared to the $n$-alkanes the $n$-alkanoic acids generally elute as well-resolved peaks, with a clean baseline signal and few co-eluting compounds. All these factors suggest the HMW $n$-alkanoic acids have great potential for both $\delta^{13} \mathrm{C}$ and $\mathrm{D} / \mathrm{H}$ compoundspecific isotope analysis at Site U1356.

\section{Inorganic geochemistry}

Ninety-seven sediment samples from Hole U1356A were taken for analyses of percent carbonate, carbon, nitrogen, and sulfur content, as well as major and trace element analyses. Sample selection was carried out in close collaboration with the sedimentology group to sample the main lithologies represented in the hole. Sampling density was approximately one sample per core (2.0-997.9 mbsf).

Calcium carbonate $\left(\mathrm{CaCO}_{3}\right.$; in weight percent) was determined on all samples by coulometric methods (see "Geochemistry and microbiology" in the "Methods" chapter). $\mathrm{CaCO}_{3}$ content is very low $(\leq 2 \mathrm{wt} \%)$ for most major lithologies (Fig. F27). Low $\mathrm{CaCO}_{3}$ values of $2-5 \mathrm{wt} \%$ were found in claystones of litholostratigraphic Unit III, nannofossil-bearing claystones of Unit III, and silty claystones of Unit VIII (see "Lithostratigraphy"). Higher $\mathrm{CaCO}_{3}$ contents of 5-30 wt\% were found in clay-bearing nannofossil limestones (Unit III), carbonate-rich claystones (Unit V), claystones (Unit VI), and silty claystones (Unit VI). Minor lithologies showed a wide range in $\mathrm{CaCO}_{3}$ content from $<1$ to $71 \mathrm{wt} \%$, with the highest values associated with limestones (Unit IV) and carbonatebearing siltstones (Unit VIII).

Carbon, nitrogen, and sulfur contents were measured on 33 selected samples. Most data obtained were below instrumental detection limits. Five samples show carbon contents $>2 \mathrm{wt} \%(2.2-8.7 \mathrm{wt} \%)$. Considering the results in context with the coulometer data, only one sample yielded measurable amounts of total organic carbon (3.17 wt\%; Sample 318-U1356A-96R-CC, 16-17 cm). This sample was also the only sample with significant amounts of sulfur $(3.2 \mathrm{wt} \%)$.

Concentrations of a selection of elements (silicon, titanium, aluminum, iron, manganese, calcium, magnesium, sodium, potassium, phosphorus, strontium, barium, vanadium, scandium, and cobalt) were obtained for all 97 bulk sediment samples by inductively coupled plasma-atomic emission spectrophotometer (ICP-AES). Representative results are shown in Figure F28, and data are reported in Table T14. Three broad intervals can be distinguished:

1. An upper interval ( 0 to $\sim 878 \mathrm{mbsf}$ ),

2. A transitional interval ( $\sim 878$ and $\sim 920 \mathrm{mbsf}$ ), and

3. A lower interval ( 920 to $\sim 1000 \mathrm{mbsf})$.

In the upper interval, silicon dioxide values fluctuate mainly between 65 and $75 \mathrm{wt} \%$. Aluminum oxide concentrations range from $10 \%$ to $15 \%$ and show a clear inverse correlation with silicon dioxide. Values for titanium, potassium, magnesium, and iron oxides are positively correlated with aluminum oxide contents. A different pattern is displayed by barium, which shows a cyclic signature from 0 to $878 \mathrm{mbsf}$, most likely associated with productivity changes. Absolute concentrations vary between 400 and $1000 \mathrm{ppm}$. Calcium oxide patterns are dominated by $\mathrm{CaCO}_{3}$-rich lithologies but show an anticorrelation with $\mathrm{SiO}_{2}$ on the finer scale.

In the transitional interval ( $\sim 878$ to $~ 920 \mathrm{mbsf}$ ), most elemental concentrations show abrupt changes (Fig. F28). Silicon dioxide varies between 58 and $73 \mathrm{wt} \%$ and is inversely correlated with $\mathrm{Al}_{2} \mathrm{O}_{3}$ values (12-23 wt\%). A similar inverse relationship with $\mathrm{SiO}_{2}$ holds for $\mathrm{TiO}_{2}$. In general, the transitional interval is characterized by widely fluctuating elemental concentrations rather than smooth increases/decreases in elemental concentrations.

The lower interval ( 920 to $\sim 1000$ mbsf) shows a narrower range of elemental concentrations, at a level different than that recorded above the transition. Silicon dioxide concentrations are generally lower, between 60 and $63 \mathrm{wt} \%$, and $\mathrm{Al}_{2} \mathrm{O}_{3}$ concentrations (as well as $\mathrm{Fe}_{2} \mathrm{O}_{3}$ and $\mathrm{TiO}_{2}$ concentrations) are higher (21-25 wt \%). $\mathrm{MgO}$ and $\mathrm{K}_{2} \mathrm{O}$ concentrations in this unit are decoupled from $\mathrm{Al}_{2} \mathrm{O}_{3}$ and instead correlate with the trend observed in $\mathrm{SiO}_{2}$ (i.e., lower absolute values).

Outliers to the overall trends described above occur in carbonate-enriched sediments (lower $\mathrm{SiO}_{2}$ and higher $\mathrm{CaO}$ contents) and sandy diamicts and sandstones (higher $\mathrm{SiO}_{2}$ contents). For example, the most extreme data point in the transitional interval just below 900 mbsf (i.e., high $\mathrm{SiO}_{2}$ and low $\mathrm{Al}_{2} \mathrm{O}_{3}, \mathrm{TiO}_{2}$, $\mathrm{MgO}$, and $\mathrm{Fe}_{2} \mathrm{O}_{3}$ ) is associated with a sandstone unit (Fig. F28).

Elemental records in the upper interval (0-878 mbsf) reflect the association with biogenic/diagenetic $\left(\mathrm{SiO}_{2}\right.$ and $\mathrm{Ba})$ and terrigenous $\left(\mathrm{Al}_{2} \mathrm{O}_{3}, \mathrm{TiO}_{2}, \mathrm{MgO}, \mathrm{Fe}_{2} \mathrm{O}_{3}\right.$, 
and $\mathrm{K}_{2} \mathrm{O}$ ) phases. The lower interval, in contrast, shows parallel patterns for $\mathrm{SiO}_{2}, \mathrm{~K}_{2} \mathrm{O}$, and $\mathrm{MgO}$, indicative of a primary terrigenous signal. When calculating the chemical index of alteration $\left(\mathrm{CIA}=\left[\mathrm{Al}_{2} \mathrm{O}_{3} /\right.\right.$ $\left.\left(\mathrm{Al}_{2} \mathrm{O}_{3}+\mathrm{CaO}^{*}+\mathrm{K}_{2} \mathrm{O}+\mathrm{Na}_{2} \mathrm{O}\right)\right] \times 100$, where $\mathrm{CaO}^{*}$ represents the $\mathrm{CaO}$ fixed in silicate minerals) (Nesbitt and Young, 1982) (Fig. F29), values between 50 and 70 can be observed in the upper interval. The values are intermediate between fresh feldspar (3350) and chemically weathered detritus (70-75) and are typical for environments affected by physical weathering (e.g., Passchier and Krissek, 2008). In detail, CIA values show a gradual increase from 0 to 878 mbsf. At the depths of unconformity WL-U5 ( $880 \mathrm{mbsf})$, an abrupt increase in CIA values is observed. Higher values in the lower interval $(>80)$ strongly indicate intense chemical weathering and manifest different environmental conditions in the source area of the sediments.

\section{Physical properties}

The shipboard physical properties program at Site U1356 included nondestructive measurements of gamma ray attenuation (GRA) bulk density, magnetic susceptibility (loop sensor), $P$-wave velocity, and natural gamma radiation (NGR) on whole-round core sections. $P$-wave velocities were determined on archive-section halves in Hole U1356A. Additional moisture, density, and porosity measurements were performed on samples taken from the working half of each suitable section in Hole U1356A. Multiaxis $P$ wave velocity measurements were performed either with the velocity probes inserted into the unconsolidated or semisoft sediments or on cube samples that were also used for moisture, density, and porosity determinations afterward. Measurements were made on all RCB cores.

\section{Whole-Round Multisensor Logger and Special Task Multisensor Logger measurements}

All core sections in Hole U1356A were measured using the Whole-Round Multisensor Logger (WRMSL) (Figs. F30, F31). Four cores (318-U1356A-47R and 91R through 93R) were also analyzed on the Special Task Multisensor Logger, as these data were of special interest at an early stage for various planning of measurement settings and for sedimentology.

\section{Gamma ray attenuation bulk density}

Using the WRMSL, GRA density was measured at $2.5 \mathrm{~cm}$ intervals (10 s integration time). Variations in
GRA density may reflect variations in lithology, consolidation, cementation, and porosity. The measured values are as much as $2.7 \mathrm{~g} / \mathrm{cm}^{3}$. In Figure F31, we plotted the filtered data.

GRA density data generally change at the identified lithostratigraphic boundaries (Fig. F31) and also support the location of the main seismic unconformities WL-U5-WL-U3. We observed an initial increase in bulk density from the seafloor to $\sim 179 \mathrm{mbsf}$, where silty claystones with clasts dominate. Below this horizon, GRA densities are slightly lower and then increase with depth to the bottom of the hole. However, below the main reflectors in the section (e.g., $\sim 460$ mbsf [unconformity WL-U5], 695 mbsf [unconformity WL-U4], and $~ 880$ mbsf [unconformity WL-U3]; see "Site summary") the regular increase in GRA density is interrupted by steps of slower change (Fig. F31).

\section{Magnetic susceptibility}

Whole-core magnetic susceptibility was measured at $2.5 \mathrm{~cm}$ intervals ( $2 \mathrm{~s}$ measurement time). The raw data values range from 0 to 7783.5 instrument units (Fig. F30). The highest values represent individual gravel clasts (igneous or metamorphic). In addition, many core tops contain gravel- to cobble-sized clasts that are interpreted as fall-in from higher locations in the hole. These clasts are usually associated with peak values in magnetic susceptibility; therefore, huge peaks occur at the top of most cores. The magnetic susceptibility values for these "artifacts" have been removed from the data of each of these cores for a more realistic plotting of the data in the barrel sheets of individual cores as well as in Figure F30.

Additionally, many gravel-sized clasts are found within the recovered cores. These clasts have a variety of lithologies (see "Lithostratigraphy") and frequently represent local peaks in magnetic susceptibility. These were retained in all plots.

Magnetic susceptibility data exhibit rhythmic changes especially visible in the cores with improved recovery, starting at Core 318-U1356A-47R but even more so in Core 68R downhole. These changes in magnetic susceptibility likely reflect variations in the input of biogenic and terrigenous sediments and were used for prediction of the sediment composition (bioturbated carbonate-bearing units versus finely laminated carbonate-free intervals) on a centimeter to decimeter scale before the cores were split to assist the sedimentologists (see "Lithostratigraphy").

Overall, the lithostratigraphic units show a clear correlation to the magnetic susceptibility measurements. Lithostratigraphic Units I, III, and X all correspond to pronounced low magnetic susceptibility. 


\section{Natural gamma radiation}

Natural gamma radiation was measured on all core sections at $10 \mathrm{~cm}$ intervals and run on an integration time of 20 min per section (600 s per measurement). Measured values range from 18.5 to $83 \mathrm{cps}$ (Fig. F30).

The NGR measurements show several intervals of increasing values with depth from the seafloor to 200 mbsf (lithostratigraphic Unit I and Subunit IIa), followed by a gradual shift in decreasing counts in line with the diatom-rich clay ooze of Subunit IIb. Below 275 mbsf, counts increase downhole, reaching higher values in the bioturbated and laminated claystones of Unit VII ( 775 mbsf). A distinct decrease is observed in the lower part of Unit VIII and Subunit IXa (850 to $\sim 900 \mathrm{mbsf}$ ). The maximum values occur in the claystones of Cores 98R through 104R of lithostratigraphic and Units X and XI.

\section{P-wave velocity}

$P$-wave velocity measurements were made at $5 \mathrm{~cm}$ intervals. Measured velocities are as high as $3452 \mathrm{~m} / \mathrm{s}$ (Fig. F32). However, beginning with Core 39R, there were very few WRMSL $P$-wave velocity measurements. This is likely due to the increasingly reduced diameter with depth of the RCB cores within the liner. The $P$-wave logger instrument of the WRMSL was no longer reliably able to transmit the ultrasonic wave through the core at lower core diameters.

$P$-wave velocities were also measured on the working half of the split core or on cube samples using the $P$ wave gantry. In softer sediments, when the WRMSL was still collecting data, a single measurement was taken per section. As the WRMSL data degraded in quantity, $P$-wave measurements on the split core were increased. Depending on core recovery and lithification, up to 6 measurements per section were made with the Section Half Velocity Gantry. These measurements range from 1090 to $5483 \mathrm{~m} / \mathrm{s}$. However, the highest velocities correspond to the gravel clasts, whereas the lowest velocities reflect measurements in cracked or otherwise unsuitable deformed material. If we remove these outlier velocity measurements, the data range between 1500 and 2800 m/s, as is plotted in Figure F32.

Additionally, when the degree of lithification of the samples was high enough, multi-axis $P$-wave measurements were performed on the samples also used for moisture and density (MAD) measurements. These measurements were made before the start of MAD analysis. Additionally, deionized water was not used during these measurements to avoid contaminating the MAD measurements. Preference was made to measure the $Z$-axis $P$-wave velocities, and they range from 1633 to $2500 \mathrm{~m} / \mathrm{s}$. Measurements for the $y$-axis have a similar range, from 1638 to $2680 \mathrm{~m} / \mathrm{s}$ (Fig. F32).

\section{Moisture and density measurements}

Measurements of density, porosity, and grain density were undertaken on 249 samples taken from Hole U1356A. Depending on core recovery and quality, one sample was taken per section. These samples were carefully selected to cover the representative lithology of each core section. Care was also taken to avoid locations of obvious drilling disturbances. These samples were measured for wet mass, dry mass, and dry volume and, by using these measurements, porosity, percent water mass, dry density, bulk density, and grain density were calculated.

The bulk densities (MAD) from discrete samples are also plotted in Figure F31 and have a raw data range of $1.05-2.60 \mathrm{~g} / \mathrm{cm}^{3}$ (Fig. F31).

In the upper $225 \mathrm{~m}$ of the hole, both GRA densities and bulk densities of samples (MAD) are in good agreement. However, below 225 mbsf, the GRA density results are consistently lower than those measured from physical samples. We interpret this to be a result of the reduced diameter of the RCB cores recovered in the lower, more lithified portions of the hole. This reduced diameter likely systematically underestimated the bulk density as measured by the GRA density meter and is especially pronounced in the diamictites and mudstones with clasts with alternating bioturbated and laminated mudstones of lithostratigraphic Unit IV (459.4-593.8 mbsf).

Grain density values increase from $\sim 2.6 \mathrm{~g} / \mathrm{cm}^{3}$ at the seafloor to $\sim 2.8 \mathrm{~g} / \mathrm{cm}^{3}$ at 1000 mbsf. Porosity ranges from $76 \%$ to $12 \%$ and generally decreases with depth (Fig. F33). Bulk and dry densities exhibit increasing values with depth (Fig. F34). In detail, the trend of compaction reflects variations depending on the lithostratigraphic unit. Moisture content and void ratio show similar trends to porosity, which is expected (Fig. F35).

\section{Thermal conductivity}

Where possible, thermal conductivity was measured once per core using the full-space probe on the cores, usually near the middle of sections. It was frequently not possible to measure thermal conductivity because the core was too lithified to insert the full-space needle probe. Consequently, no thermal conductivity measurements were made on cores from below 560 mbsf.

Thermal conductivity in fine-grained sediments is, as a first approximation, a linear combination of the conductivities of the grains and the interstitial water and therefore depends upon porosity or water content 
and lithology. Overall, thermal conductivity values $(\mathrm{W} /[\mathrm{m} \cdot \mathrm{K}])$ increase with depth, which, as expected, parallels decreasing moisture content, (Fig. F36).

\section{References}

Barker, P.E, Kennett, J.P., et al., 1988. Proc. ODP, Init. Repts., 113: College Station, TX (Ocean Drilling Program). doi:10.2973/odp.proc.ir.113.1988

Berggren, W.A., 1992. Neogene planktonic foraminifer magnetobiostratigraphy of the southern Kerguelen Plateau (Sites 747, 748, and 751). In Wise, S.W., Jr., Schlich, R., et al., Proc. ODP, Sci. Results, 120: College Station, TX (Ocean Drilling Program), 631-647.

doi:10.2973.odp.proc.sr.120.153.1992

Berggren, W.A., Kent, D.V., Swisher, C.C., III, and Aubry, M.-P., 1995. A revised Cenozoic geochronology and chronostratigraphy. In Berggren, W.A., Kent, D.V., Aubry, M.-P., and Hardenbol, J. (Eds.), Geochronology, Time Scales and Global Stratigraphic Correlation. Spec. Publ._SEPM (Soc. Sediment. Geol.), 54:129-212.

Brinkhuis, H., Sengers, S., Sluijs, A., Warnaar, J., and Williams, G.L., 2003. Latest Cretaceous-earliest Oligocene and Quaternary dinoflagellate cysts, ODP Site 1172, East Tasman Plateau. In Exon, N.F., Kennett, J.P., and Malone, M.J., Proc. ODP, Sci. Res., 189: College Station, TX (Ocean Drilling Program), 1-36. doi:10.2973/ odp.proc.sr.189.106.2003

Cande, S.C., and Kent, D.V., 1992. A new geomagnetic polarity time scale for the Late Cretaceous and Cenozoic. J. Geophys. Res., 97(B10):13917-13951. doi:10.1029/92JB01202

Cody, R.D., Levy, R.H., Harwood, D.M., and Sadler, P.M., 2008. Thinking outside the zone: high-resolution quantitative diatom biochronology for the Antarctic Neogene. Palaeogeogr., Palaeoclimatol., Palaeoecol., 260(12):92-121. doi:10.1016/j.palaeo.2007.08.020

Conte, M.H., Sicre, M.-A., Rühlemann, C., Weber, J.C., Schulte, S., Schulz-Bull, D., and Blanz, T., 2006. Global temperature calibration of the alkenone unsaturation index $\left(\mathrm{U}^{\mathrm{K}^{\prime}}{ }_{37}\right)$ in surface waters and comparison with surface sediments. Geochem., Geophys., Geosyst., 7(2):Q02005. doi:10.1029/2005GC001054

Conte, M.H., Volkman, J.K., and Eglinton, G., 1994. Lipid biomarkers of Haptophyta. In Green, J.C., and Leadbeater, B.S.C. (Eds.), The Haptophyte Algae: Oxford (Clarendon Press), 351-377.

Cramer, B.S., Wright, J.D., Kent, D.V., and Aubry, M.-P., 2003. Orbital climate forcing of $\delta^{13} \mathrm{C}$ exursions in the late Paleocene-early Eocene (Chrons C24n-C25n). Palaeogeography, 18(4):1097-1122. doi:10.1029/ 2003PA000909

Crouch, E.M., and Brinkhuis, H., 2005. Environmental change across the Paleocene-Eocene transition from eastern New Zealand: a marine palynological approach. Mar. Micropalaeontol., 56(3-4):138-160. doi:10.1016/ j.marmicro.2005.05.002

Donda, F., Brancolini, G., De Santis, L., and Trincardi, F., 2003. Seismic facies and sedimentary processes on the continental rise off Wilkes Land (East Antarctica): evidence of bottom current activity. Deep-Sea Res., Part II, 50(8-9):1509-1527. doi:10.1016/S0967-

0645(03)00075-4

Eglinton, G., and Calvin, M., 1967. Chemical fossils. Sci. Am., 216(1):32-43. doi:10.1038/

scientificamerican0167-32

Eglinton, G., Gonzales, A.G., Hamilton, R.J., and Raphael, R.A., 1962. Hydrocarbon constituents of the wax coatings of plant leaves: a taxonomic survey. Phytochemistry, 1(2):89-102. doi:10.1016/S0031-9422(00)88006-1

Eglinton, G., and Hamilton, R.J., 1967. Leaf epicuticular waxes. Science, 156(3780):1322-1335. doi:10.1126/science.156.3780.1322

Ehrmann, W., Setti, M., and Marinoni, L., 2005. Clay minerals in Cenozoic sediments off Cape Roberts (McMurdo Sound, Antarctica) reveal palaeoclimatic history. Palaeogeogr., Palaeoclimatol., Palaeoecol., 229(3):187-211. doi:10.1016/j.palaeo.2005.06.022

Ehrmann, W.U., 1991. Implications of sediment composition on the southern Kerguelen Plateau for paleoclimate and depositional environment. In Barron, J., Larsen, B., et al., Proc. ODP, Sci. Results, 119: College Station, TX (Ocean Drilling Program), 185-210. doi:10.2973/ odp.proc.sr.119.121.1991

Escutia, C., Eittreim, S.L., Cooper, A.K., and Nelson, C.H., 2000. Morphology and acoustic character of the Antarctic Wilkes Land turbidite systems: ice-sheet-sourced versus river-sourced fans. J. Sediment. Res., 70(1):84-93. doi:10.1306/2DC40900-0E47-11D78643000102C1865D

Escutia, C., Nelson, C.H., Acton, G.D., Eittreim, S.L., Cooper, A.K., Warnke, D.A., and Jaramillo, J.M., 2002. Current controlled deposition on the Wilkes Land continental rise, Antarctica. In Stow, D.A.V., Pudsey, C.J., Howe, J.A., Faugeres, J.-C., and Viana, A.R. (Eds.), Deep-Water Contourite Systems: Modern Drifts and Ancient Series, Seismic and Sedimentary Characteristics. Mem.Geol. Soc. London, 22(1):373-384. doi:10.1144/ GSL.MEM.2002.022.01.26

Esper, O., and Zonneveld, K.A.F., 2007. The potential of organic-walled dinoflagellate cysts for the reconstruction of past sea-surface conditions in the Southern Ocean. Mar. Micropaleontol., 65(3-4):185-212. doi:10.1016/j.marmicro.2007.07.002

Frey, R.W., Pemberton, S.G., and Saunders, T.D.A., 1990. Ichnofacies and bathymetry: a passive relationship. $J$. Paleontol., 64(1):155-158. http://jpaleontol.geoscienceworld.org/cgi/content/abstract/64/1/155

Gagosian, R.B., Nigrelli, G.E., and Volkman, J.K., 1983. Vertical transport and transformation of biogenic organic compounds from a sediment trap experiment off the coast of Peru. In Suess, E., and Thiede, J. (Eds.), Coastal Upwelling, Its Sediment Record: Part A, Responses of the Sedimentary Regime to Present Coastal Upwelling. NATO Conf. Ser. IV, 10A:241-272.

Gradstein, F.M., Ogg, J.G., and Smith, A. (Eds.), 2004. A Geologic Time Scale 2004: Cambridge (Cambridge Univ. Press). http://cambridge.org/uk/catalogue/catalogue.asp?isbn=9780521781428 
Goodman, D.K., and Ford, L.N., Jr., 1983. Preliminary dinoflagellate biostratigraphy for the middle Eocene to lower Oligocene from the southwest Altantic Ocean. In Ludwig, W.J., Krasheninnikov, V.A., et al., Init. Repts. DSDP, 71: Washington, DC (U.S. Govt. Printing Office), 859-977. doi:10.2973/dsdp.proc.71.131.1983

Härtner, T., Straub, K.L., and Kannenberg, E., 2005. Occurrence of hopanoid lipids in anaerobic Geobacter species. FEMS Microbiol. Lett., 243(1):59-64. doi:10.1016/ j.femsle.2004.11.039

Hayes, D.E., Frakes, L.A., et al., 1975. Init. Repts. DSDP, 28: Washington, DC (U.S. Govt. Printing Office). doi:10.2973/dsdp.proc.28.1975

Huber, B.T., and Quillévéré, F., 2005. Revised Paleogene planktonic foraminiferal biozonation for the Austral realm. J. Foraminiferal Res., 35(4):229-314. doi:10.2113/ 35.4.299

Kolattukudy, P.E., 1976. Chemistry and Biochemistry of Natural Waxes: New York (Elsevier).

Kominz, M.A., Browning, J.V., Miller, K.G., Sugarman, P.J., Misintseva, S., and Scotese, C.R., 2008. Late Cretaceous to Miocene sea-level estimates from the New Jersey and Delaware coastal plain coreholes: an error analysis. Basin Res., 20(2):211-226. doi:10.1111/j.13652117.2008.00354.x

Loeblich, A.R., and Tappan, H., 1988. Foraminiferal Genera and Their Classification (Vol. 2): New York (Van Nostrand Reinhold Co.).

Lourens, L.J., Sluijs, A., Kroon, D., Zachos, J.C., Thomas, E., Röhl, U., Bowles, J., and Raffi, I., 2005. Astronomical pacing of late Palaeocene to early Eocene global warming events. Nature (London, U. K.), 435(7045):10831087. doi:10.1038/nature03814

Marlowe, I.T., Green, J.C., Neal, A.C., Brassell, S.C., Eglinton, G., and Course, P.A., 1984. Long-chain $\left(n-\mathrm{C}_{37}-\mathrm{C}_{39}\right)$ alkenones in the Prymnesiophyceae. Distribution of alkenones and other lipids and their taxonomic significance. Br. Phycol. J., 19(3):203-216. doi:10.1080/ 00071618400650221

Martini, E., 1971. Standard Tertiary and Quaternary calcareous nannoplankton zonation. Proc. Int. Conf. Planktonic Microfossils, 2:739-785.

McKenzie, D., 1978. Some remarks on the development of sedimentary basins. Earth Planet. Sci. Lett., 40(1):25-32. doi:10.1016/0012-821X(78)90071-7

Müller, P.J., Kirst, G., Ruhland, G., von Storch, I., and Rosell-Melé, A., 1998. Calibration of the alkenone paleotemperature index $\mathrm{U}_{37^{\mathrm{K}}}{ }^{\prime}$ based on core-tops from the eastern South Atlantic and the global ocean $\left(60^{\circ} \mathrm{N}-\right.$ $\left.60^{\circ} \mathrm{S}\right)$. Geochim. Cosmochim. Acta, 62(10):1757-1772. doi:10.1016/S0016-7037(98)00097-0

Nesbitt, H.W., and Young, G.M., 1982. Early Proterozoic climates and plate motions inferred from major element chemistry of lutites. Nature (London, U. K.), 299(5885):715-717. doi:10.1038/299715a0

Nicolo, M.J., Dickens, G.R., Hollis, C.J., and Zachos, J.C., 2007. Multiple early Eocene hyperthermals: their sedimentary expression on the New Zealand continental margin and in the deep sea. Geology, 35(8):699-702. doi:10.1130/G23648A.1
Okada, H., and Bukry, D., 1980. Supplementary modification and introduction of code numbers to the low-latitude coccolith biostratigraphic zonation (Bukry, 1973; 1975). Mar. Micropaleontol., 5:321-325. doi:10.1016/ 0377-8398(80)90016-X

Pagani, M., Freeman, K.H., Ohkouchi, N., and Caldeira, K., 2002. Comparison of water column $\left[\mathrm{CO}_{2 \mathrm{aq}}\right]$ with sedimentary alkenone-based estimates: a test of the alkenone- $\mathrm{CO}_{2}$ proxy. Paleoceanography, 17(4):1069-1080. doi:10.1029/2002PA000756

Pancost, R.D., Steart, D.S., Handley, L., Collinson, M.E., Hooker, J.J., Scott, A.C., Grassineau, N.V., and Glasspool, I.J., 2007. Increased terrestrial methane cycling at the Palaeocene-Eocene Thermal Maximum. Nature (London, U. K.), 449(7150):332-335.

doi:10.1038/nature06012

Passchier, S., and Krissek, L., 2008. Oligocene-Miocene Antarctic continental weathering record and paleoclimatic implications, Cape Roberts drilling project, Ross Sea, Antarctica. Palaeogeogr., Palaeoclimatol., Palaeoecol., 260(1):30-40. doi:10.1016/j.palaeo.2007.08.012

Prahl, F.G., and Wakeham, S.G., 1987. Calibration of unsaturation patterns in long-chain ketone compositions for paleotemperature assessment. Nature (London, U. K.), 330(6146):367-369. doi:10.1038/330367a0

Robert, C., Diester-Haass, L., and Chamley, H., 2002. Late Eocene-Oligocene oceanographic development at southern high latitudes, from terrigenous and biogenic particles: a comparison of Kerguelen Plateau and Maud Rise, ODP Sites 744 and 689. Mar. Geol., 191(1-2):37-54. doi:10.1016/S0025-3227(02)00508-X

Robert, C., and Kennett, J.P., 1992. Paleocene and Eocene kaolinite distribution in the South Atlantic and Southern Ocean: Antarctic climatic and paleoceanographic implications. Mar. Geol.,103(1-3):99-110. doi:10.1016/ 0025-3227(92)90010-F

Robert, C., and Kennett, J.P., 1994. Antarctic subtropical humid episode at the Paleocene-Eocene boundary: claymineral evidence. Geology, 22(3):211-214. doi:10.1130/ 0091-7613(1994)022<0211:ASHEAT>2.3.CO;2

Rögl, F., 1976. Late Cretaceous to Pleistocene foraminifera from the Southeast Pacific Basin, DSDP Leg 35. In Hollister, C.D., Craddock, C., et al., Init. Repts. DSDP, 35: Washington, DC (U.S. Govt. Printing Office), 539-555. doi:10.2973/dsdp.proc.35.133.1976

Rohmer, M., Bouvier-Nave, P., and Ourisson, G., 1984. Distribution of hopanoid triterpenes in prokaryotes. J. Gen. Microbiol., 130:1137-1150. doi:10.1099/00221287-1305-1137

Seilacher, A., 1967. Bathymetry of trace fossils. Mar. Geol., 5(5-6):413-428. doi:10.1016/0025-3227(67)90051-5

Sluijs, A., Bowen, G.J., Brinkhuis, H., Lourens, L.J., and Thomas, E., 2007. The Palaeocene-Eocene Thermal Maximum super greenhouse: biotic and geochemical signatures, age models and mechanisms of global change. In Williams, M., Haywood, A.M., Gregory, F.J., and Schmidt, D.N. (Eds.), Deep-Time Perspectives on Climate Change: Marrying the Signal from Computer Models and Biological Proxies. Micropaleontol. Soc. Spec. Publ., 323-349. 
Tauxe, L., and Kent, D.V., 2004. A simplified statistical model for the geomagnetic field and the detection of shallow bias in paleomagnetic inclinations: was the ancient magnetic field dipolar? Geophys. Monogr., 145:101-115.

Villinski, J.C., Hayes, J.M., Brassell, S.C., Riggert, V.L., and Dunbar, R.B., 2008. Sedimentary sterols as biogeochemical indicators in the Southern Ocean. Org. Geochem., 39(5):567-588. doi:10.1016/j.orggeochem.2008.01.009

Volkman, J.K., Eglinton, G., Corner, E.D.S., and Forsberg, T.E.V., 1980. Long-chain alkenes and alkenones in the marine coccolithophorid Emiliania huxleyi. Phytochemistry, 19(12):2619-2622. doi:10.1016/ S0031-9422(00)83930-8

Winter, D., and Iwai, M., 2002. Data report: neogene diatom biostratigraphy, Antarctic Peninsula Pacific margin, ODP Leg 178 rise sites. In Barker, P.F., Camerlenghi, A., Acton, G.D., and Ramsay, A.T.S. (Eds.), Proc. ODP, Sci. Results, 178: College Station, TX (Ocean Drilling Program), 1-25. doi:10.2973/odp.proc.sr.178.230.2001

Publication: 2 July 2011 MS 318-104 
Figure F1. A. Bathymetric map of eastern Wilkes Land margin showing the location of Site U1356 and other Expedition 318 drill sites. Contour interval $=250 \mathrm{~m}$. Box $=$ approximate area of B. B. Navigation map of seismic reflection profiles across and in the vicinity of Site U1356. Bold line $=$ multichannel seismic reflection profile shown in Figure F2.

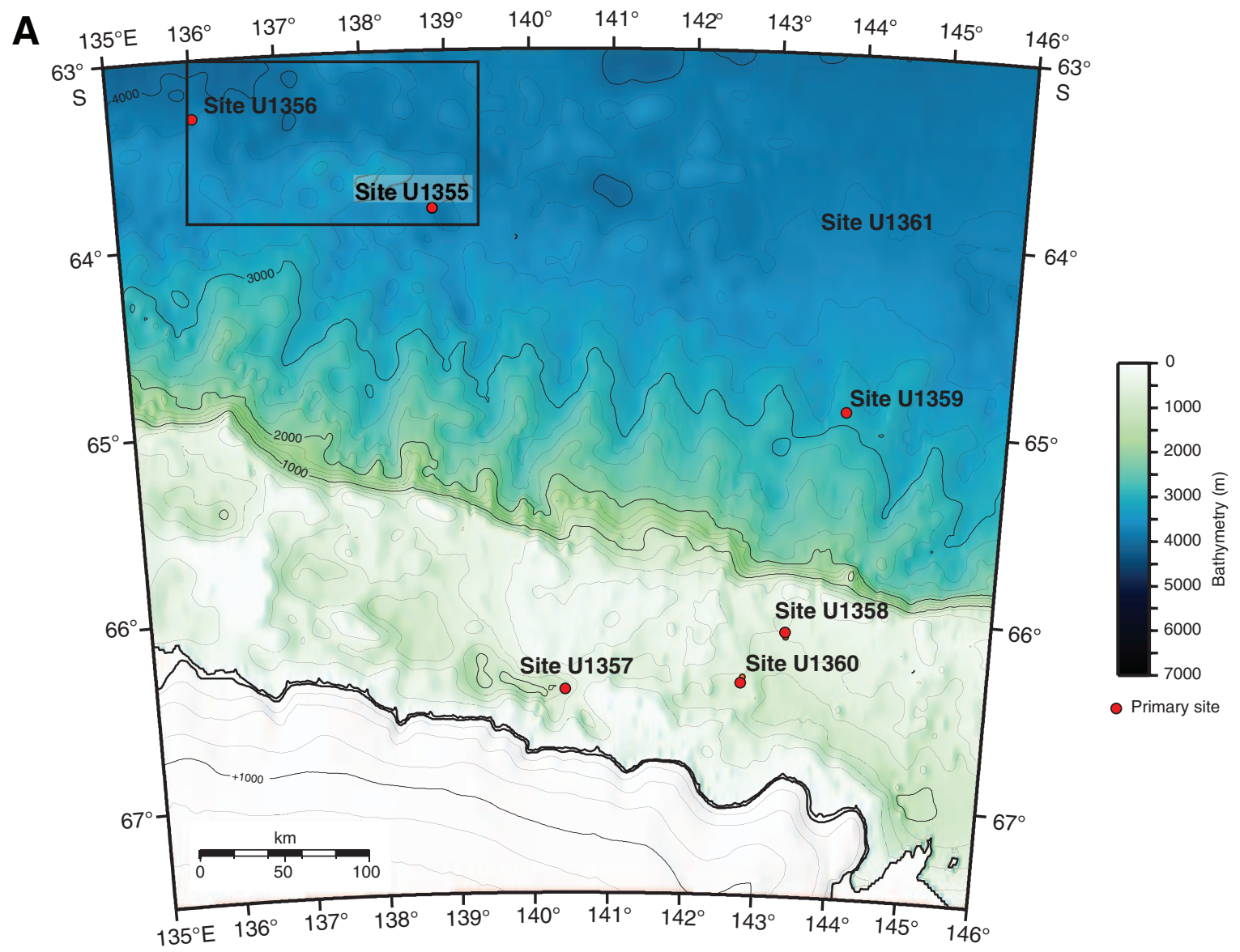

B

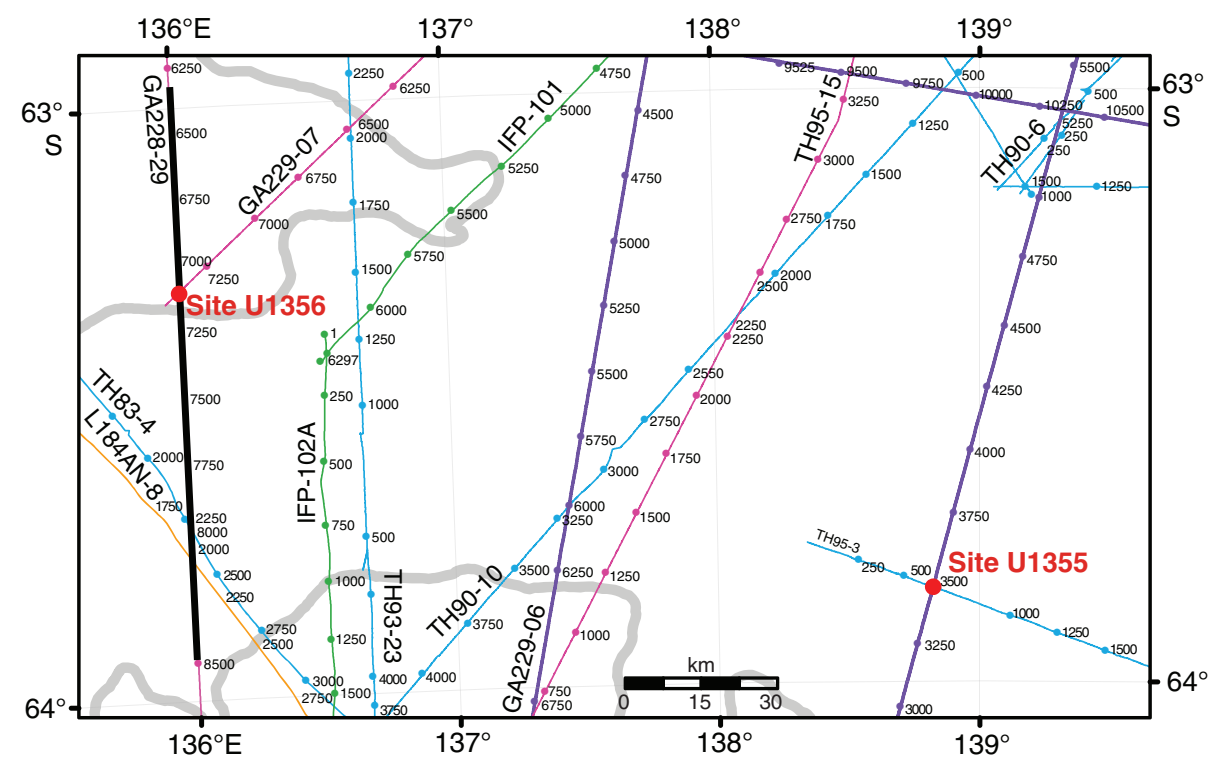


Figure F2. Multichannel seismic reflection profile across Site U1356 showing regional unconformities WL-U3, WL-U4, and WL-U5. Red rectangle = approximate penetration achieved at Site U1356. Location of seismic profile is shown in Figure F1.

\section{Shotpoint}

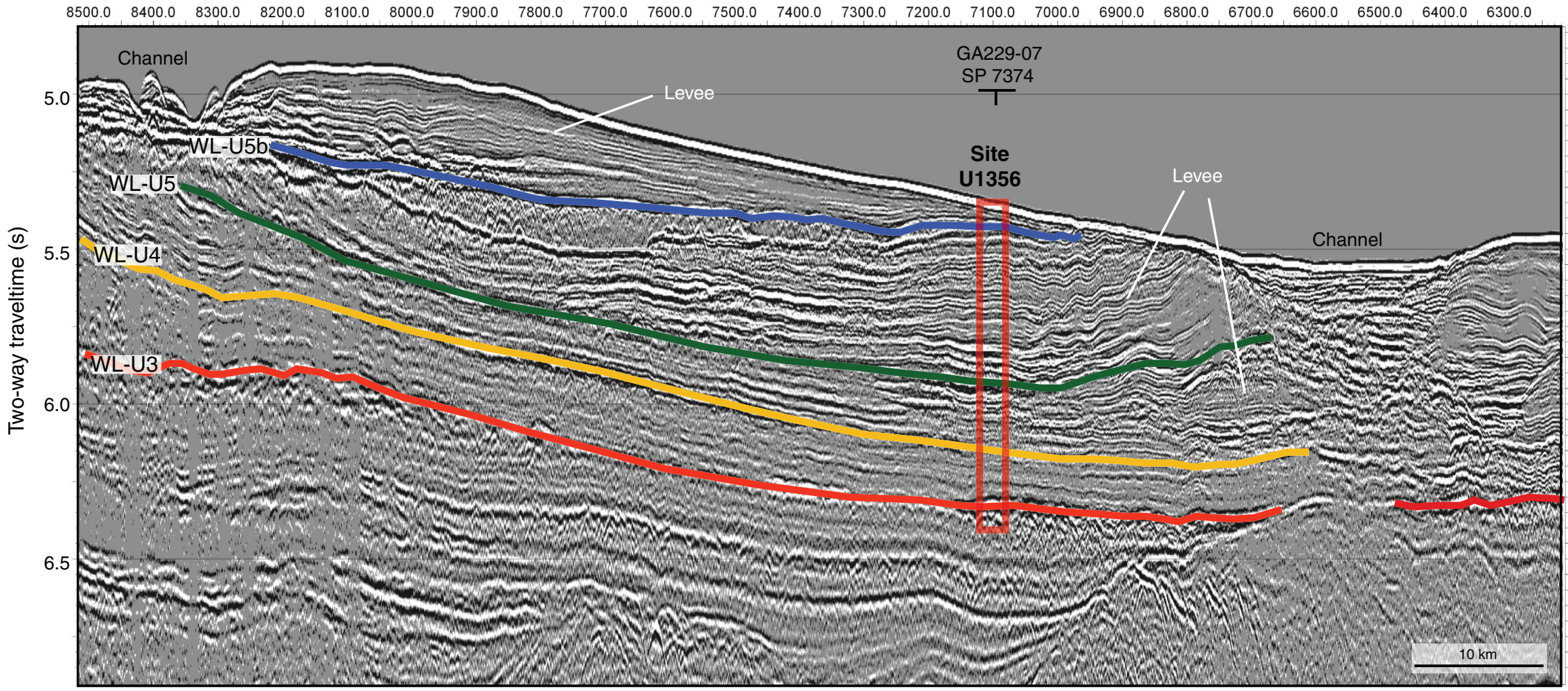


Figure F3. Lithostratigraphic Units I-XI at Site U1356 and correlation to unconformities defined in multichannel seismic profiles across the site.

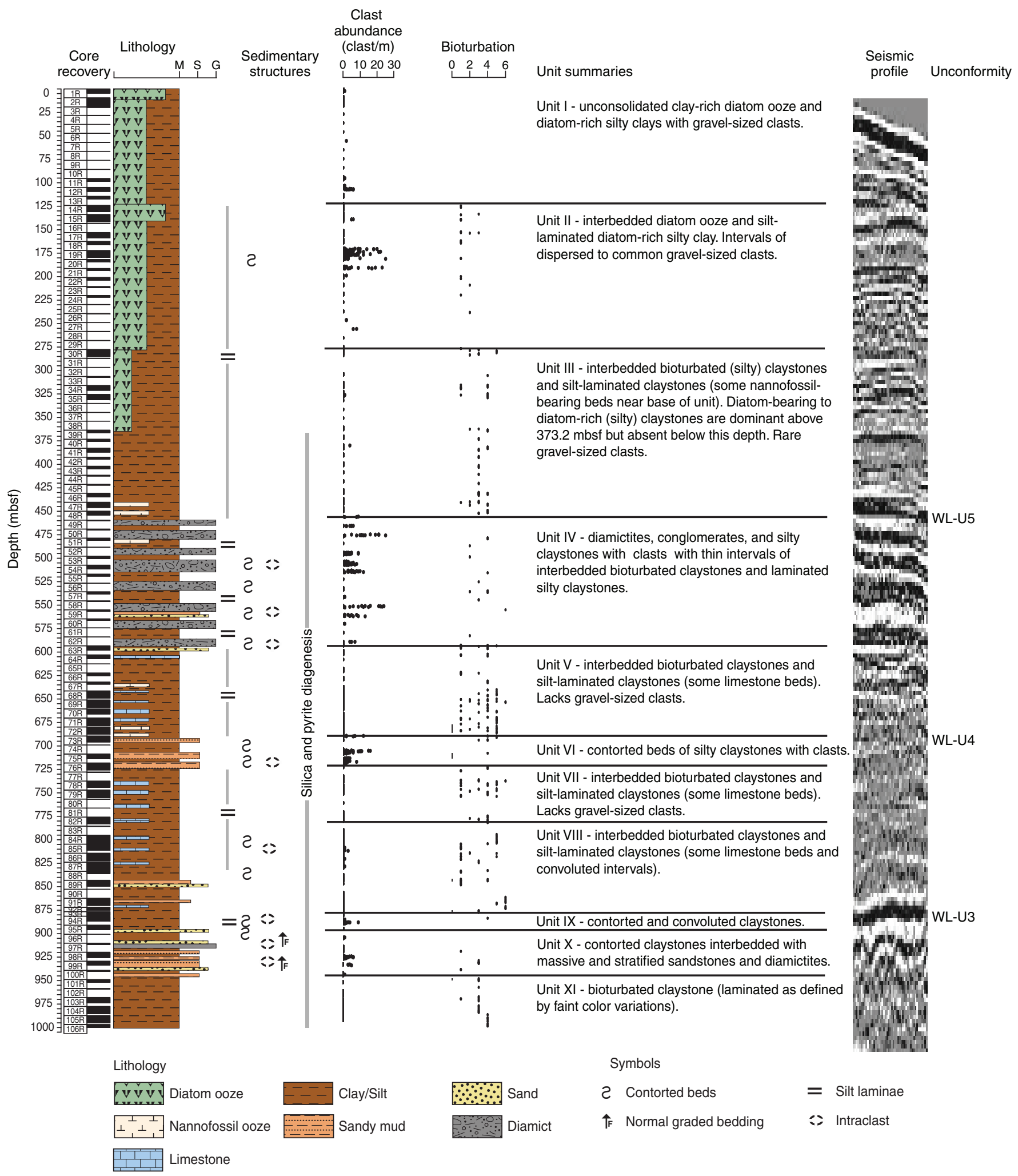


Figure F4. Biomagnetostratigraphic age-depth plot, Hole U1356A. Yellow shading = chronostratigraphic preservation. Microfossil datums are plotted by using the median depth between upper and lower samples (Table T9). Extra information derived from "shipboard" calcareous nannofossil information shown in Table T5 is also plotted. Mid-point absolute age in the average range model of Cody et al. (2008) is used for the diatom datums. $\mathrm{t}=$ top, $\mathrm{b}=$ bottom, $\mathrm{o}=$ oldest, $\mathrm{y}=$ youngest. Solid blue line $=$ best-fit sedimentation rate. The base of Hole U1356A is $\sim 53.8 \mathrm{Ma}$ based on magnetostratigraphic data.

Hole U1356A

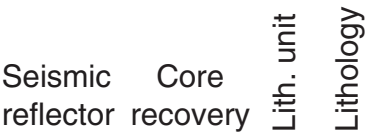

WL-U5B

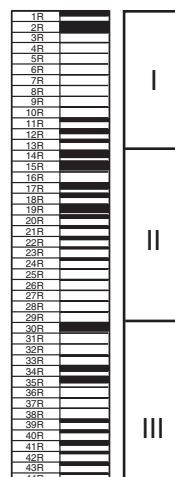

WL-U5

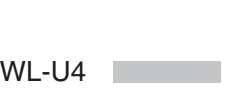

WL-U3

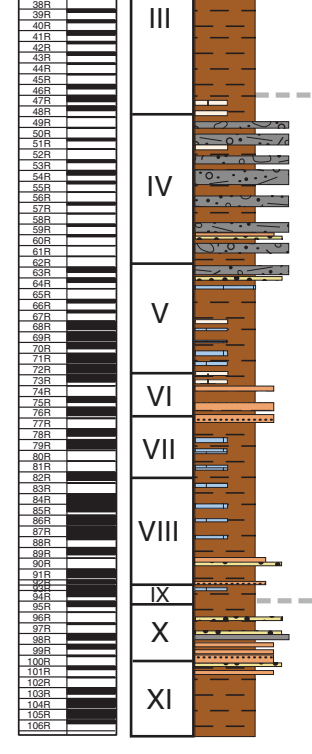

Total depth $=1000.08 \mathrm{mbsf}$

Lithology

$\left[{ }^{\perp}{ }^{\perp}\right]$ Nannofossil ooze

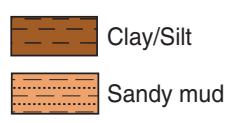

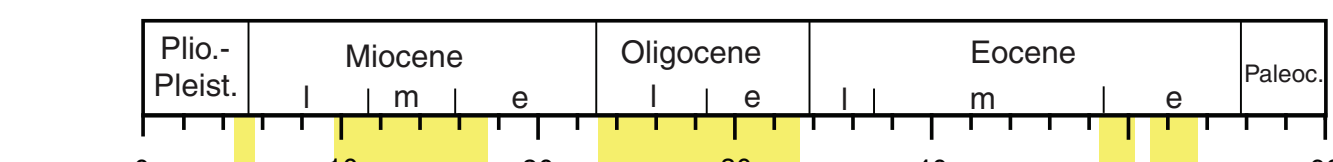

30

40

$50 \quad 60$ Age

$\nabla$ Diatom (t)

(Ma) Hiatus

$\overline{1 \mathrm{R}-2,140 \mathrm{~cm}}(9.5 \sim 4.74 \mathrm{Ma})$

Diatom (b)

$\nabla$ Radiolarian (t)

$\Delta$ Radiolarian (b)

$\nabla$ Palynomorph (t)

$\triangle$ Palynomorph (b)

$\triangleleft$ Palynomorph (y)

$\triangleleft$ Foraminifera (o)

$\triangleright$ Foraminifera $(y)$

$\triangleleft$ Nannofossil (o)

$\triangleright$ Nannofossil (y)

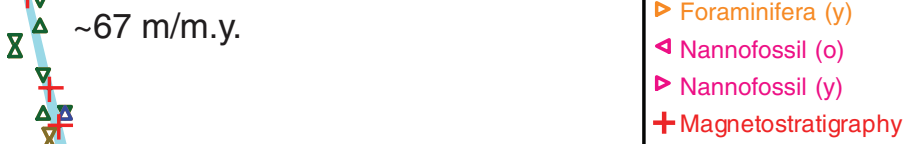

+ Magnetostratigraphy

46R-CC Hiatus/

46R-CC condensed interval (23.12-17.5 Ma)

$\triangleleft \sim 100 \mathrm{~m} / \mathrm{m} . \mathrm{y}$

600

$\triangleright$

$\triangleright$

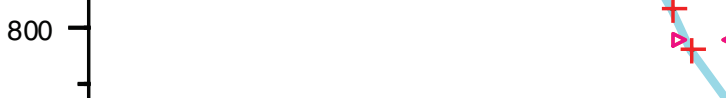

30 
Figure F5. Downhole compositional changes from smear slide data, Site U1356.

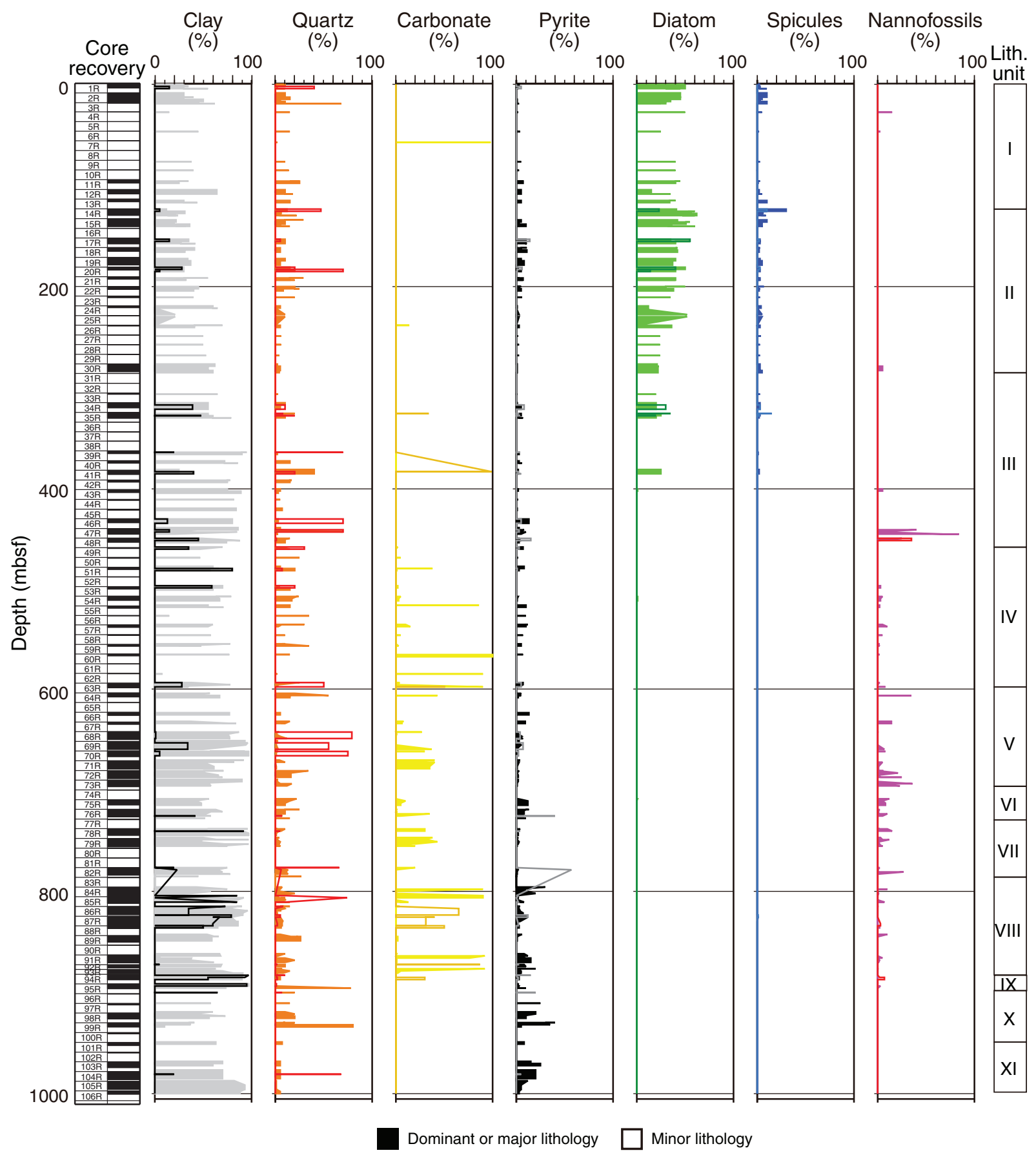


Figure F6. Clay mineral assemblage record, Hole U1356A. Peak heights were summed and normalized to an arbitrary unit of 10 , and the peak height for each mineral group was recalculated as a fractional component of this sum.

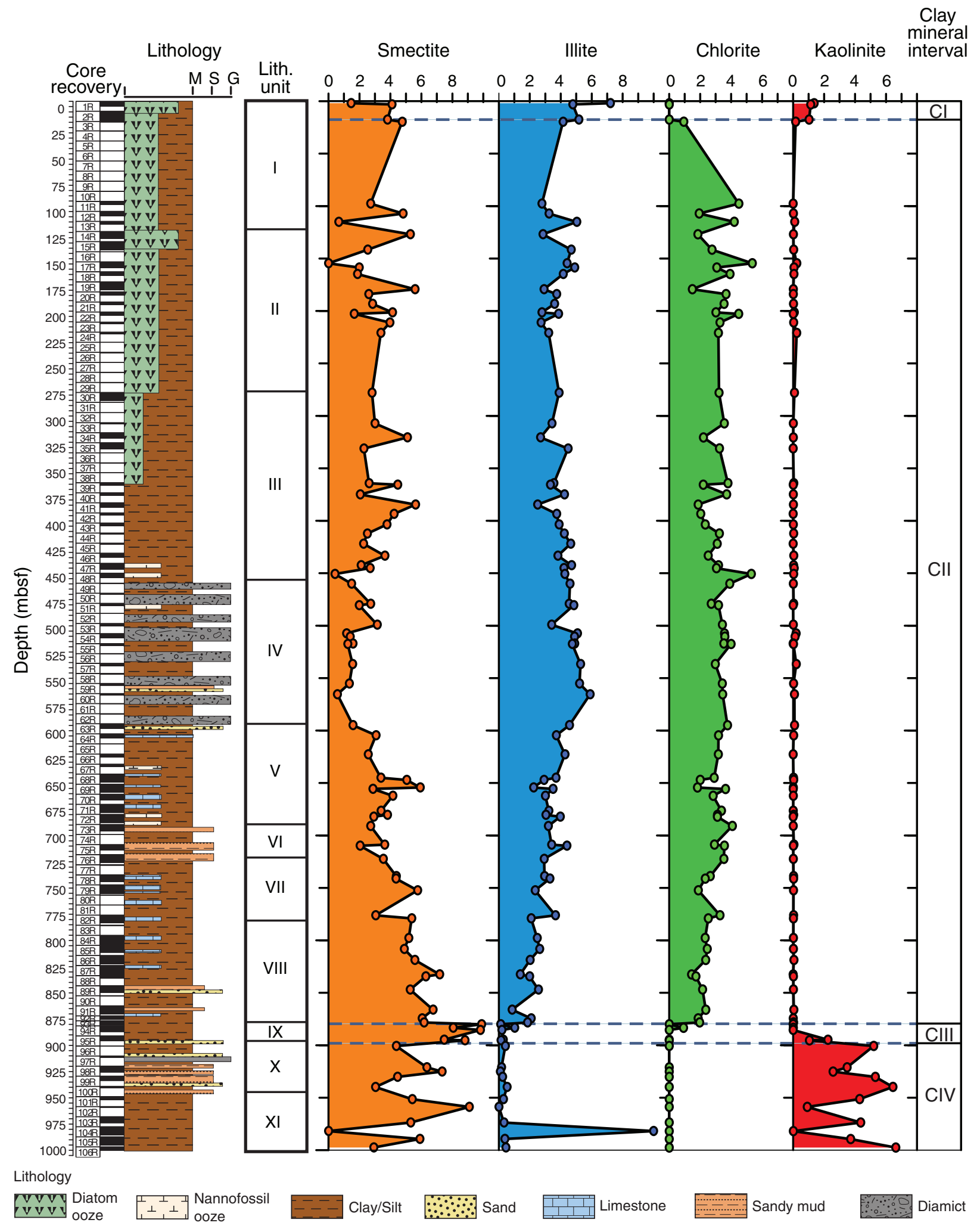


Figure F7. Core image of diatom ooze in Unit I, Hole U1356A (interval 318-U1356A-1R-3, 72-108 cm).

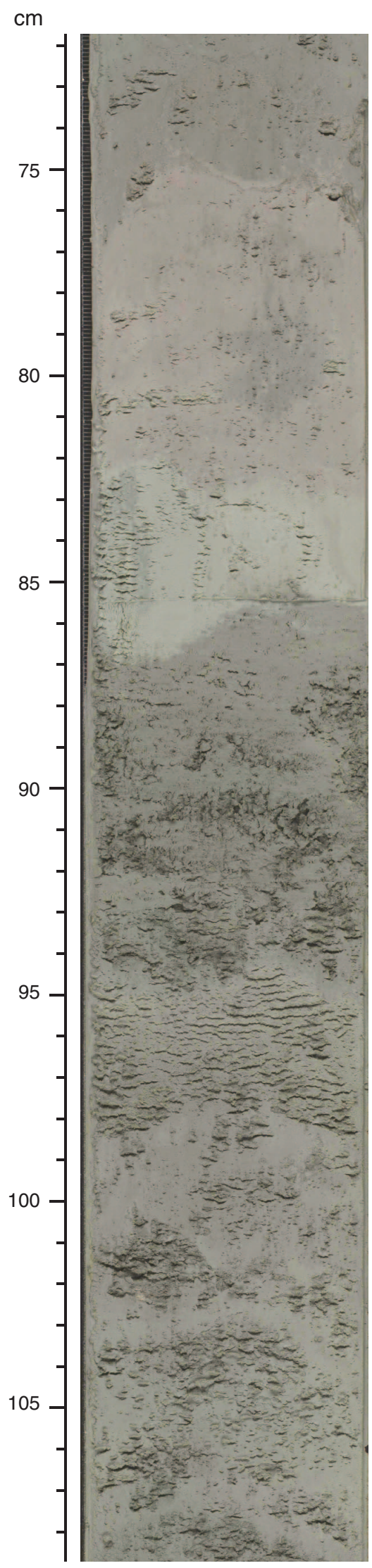


Figure F8. Core image close-up of light-dark color variations representing interlamination of diatom-rich and diatom-bearing claystone in Unit II, Hole U1356A (interval 318-U1356A-20R-1, 50-61 cm).

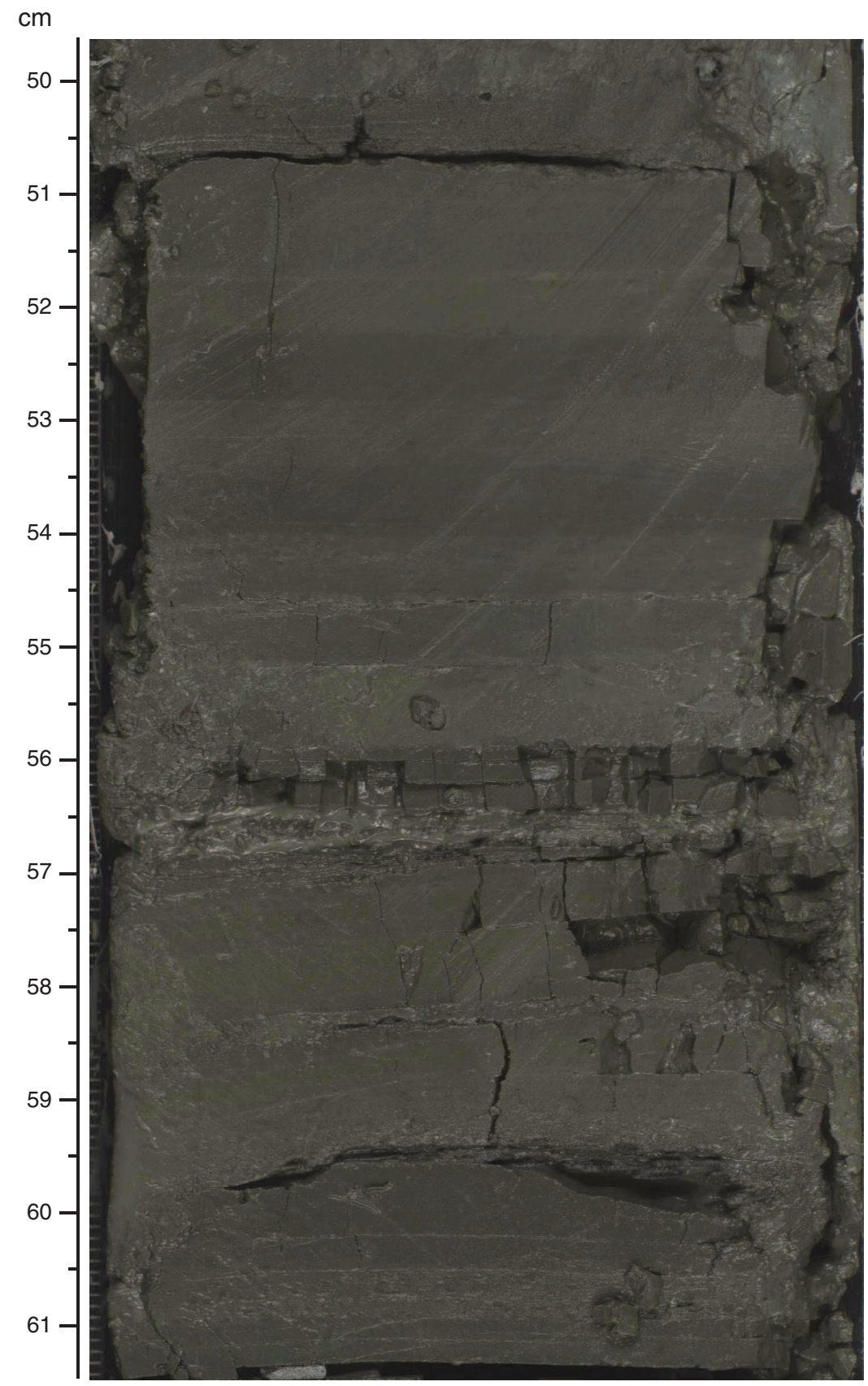


Figure F9. Core image of sheared claystone at the base of diamictite in Unit IV, Hole U1356A (interval 318U1356A-51R-1, 95-133 cm).

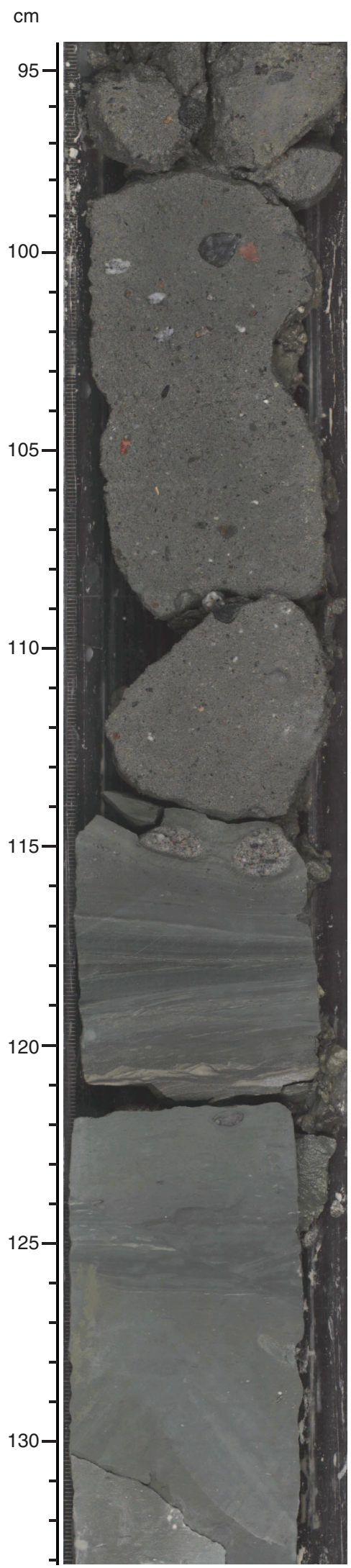


Figure F10. Core image of cyclic change from brown, sharp-based, parallel-laminated silty claystones to greenish gray bioturbated claystones in Unit V, Hole U1356A (interval 318-U1356A-72R-2, 16-57 cm).

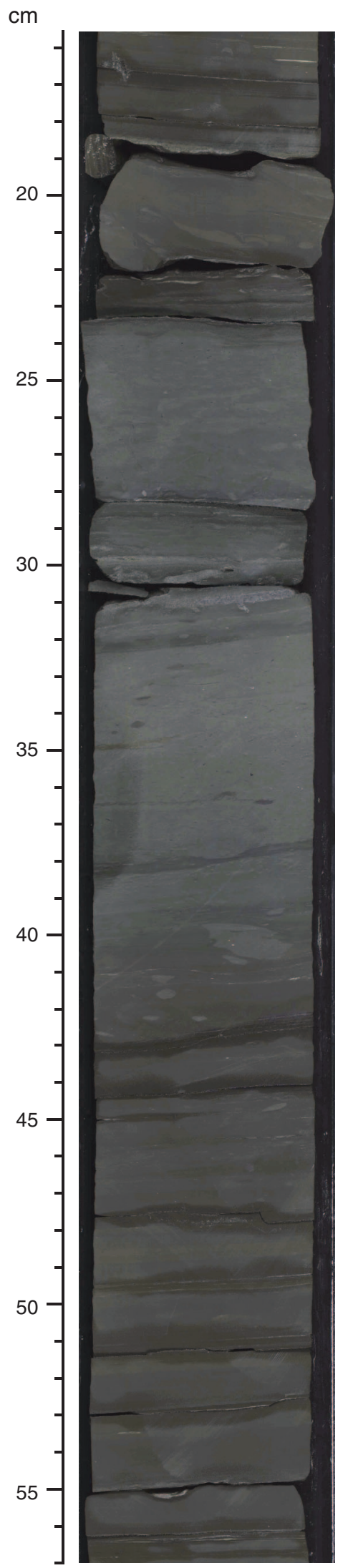


Figure F11. Core image of contorted bedding and crystalline rock clasts in Unit VI, Hole U1356A (interval 318U1356A-73R-5, 24-60 cm).

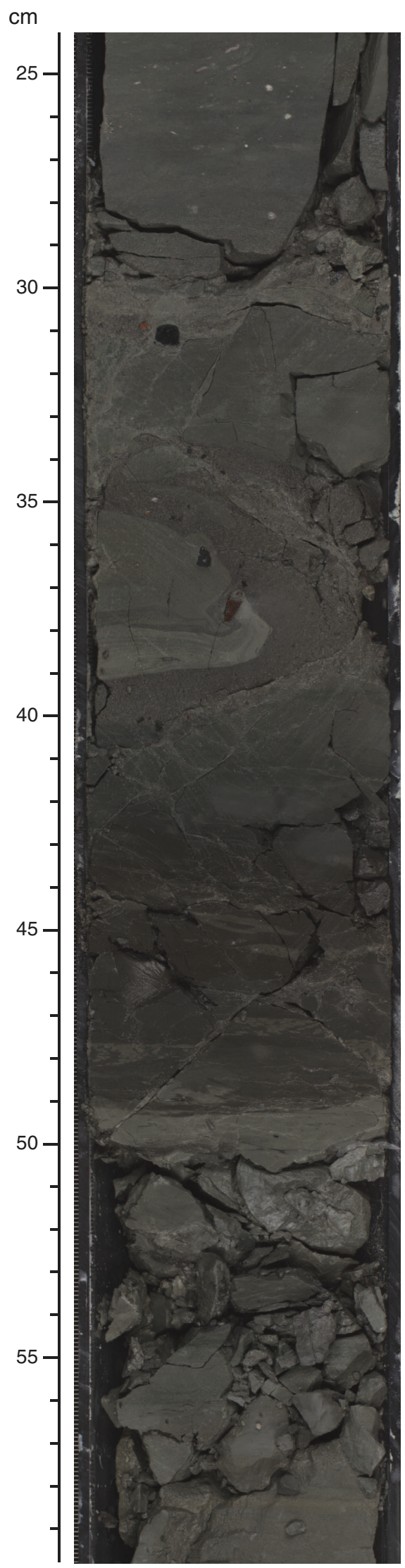


Figure F12. Core image of contorted bedding and intraformational clasts in massive claystone in Unit VIII, Hole U1356A (interval 318-U1356A-86R-4, 79-119 cm).

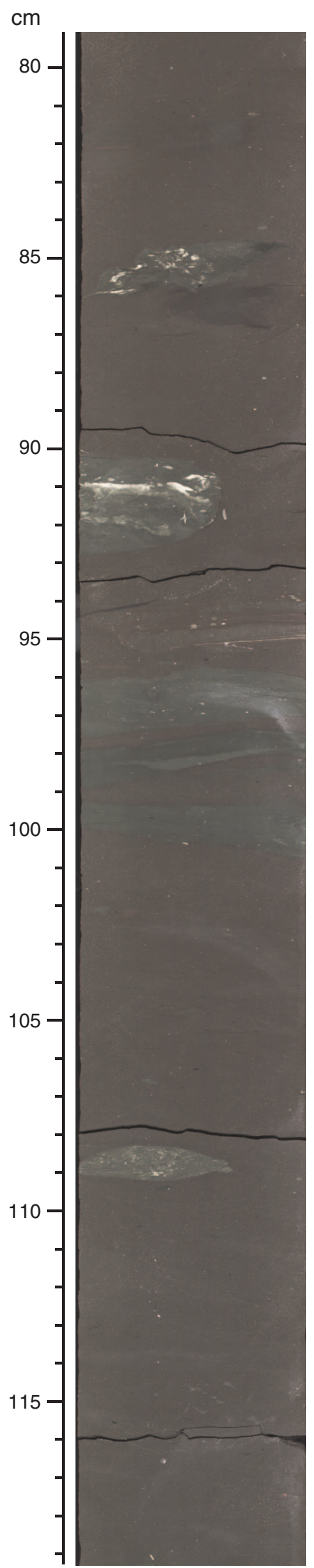


Figure F13. Core image of igneous rock clast in bioturbated green claystones in Unit XI, Hole U1356A (interval 318-U1356A-104R-1, 37-63 cm).

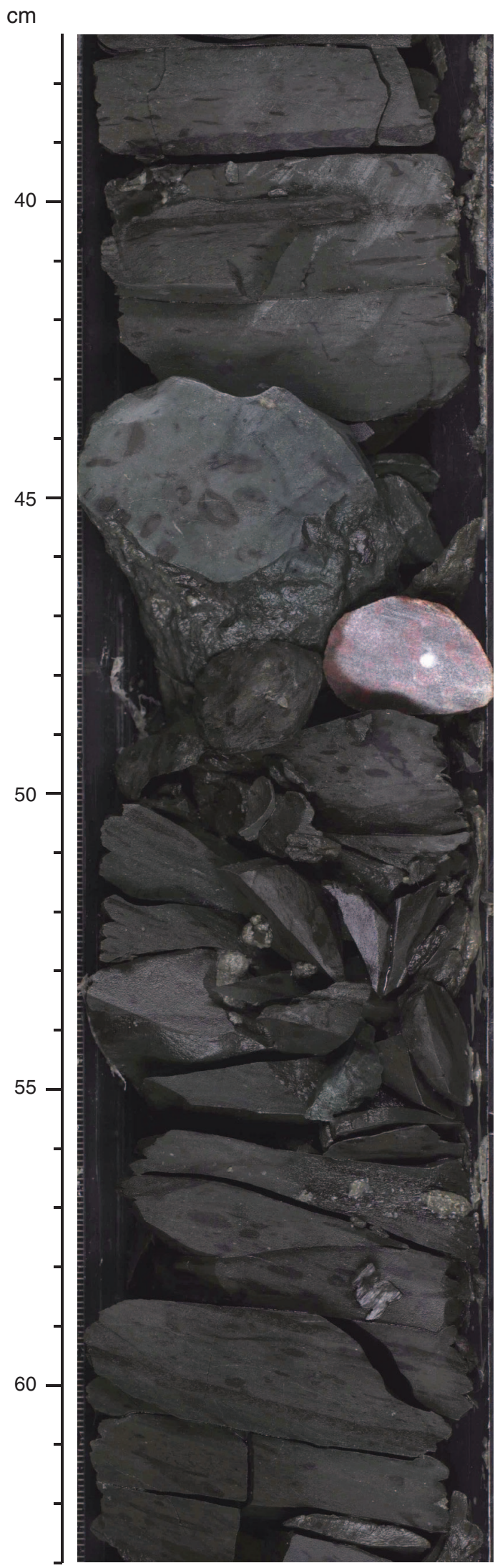


Figure F14. Overview of dinocyst assemblage changes, Hole U1356A. Oligocene and Miocene nonprotoperidinioid dinocysts comprise the oceanic oligotrophic genera Impagidinium and Batiacasphaera, as well as Operculodinium. Chemical index of alteration (CIA; see "Geochemistry and microbiology") exhibits a large decline coeval with the onset of protoperidinioid-dominated dinocyst assemblages. Dotted lines = interval shown in Figure F15.

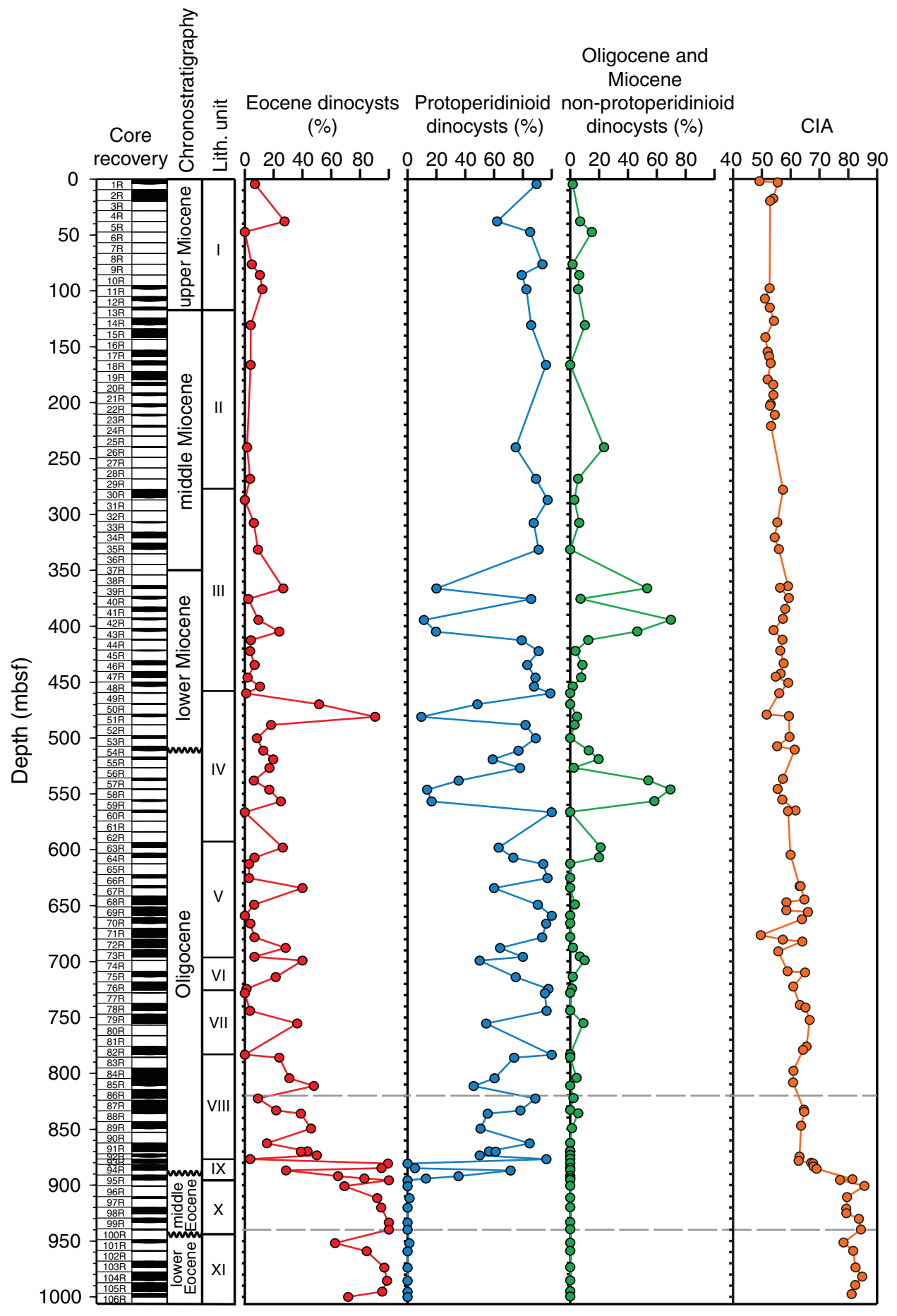


Figure F15. Eocene-Oligocene transitional interval, Hole U1356A. Oligocene and Miocene nonprotoperidinioid dinocysts comprise the oceanic oligotrophic genera Impagidinium and Batiacasphaera, as well as Operculodinium. Chemical index of alteration (CIA; see "Geochemistry and microbiology") exhibits a large decline coeval with the onset of protoperidinioid-dominated dinocyst assemblages.

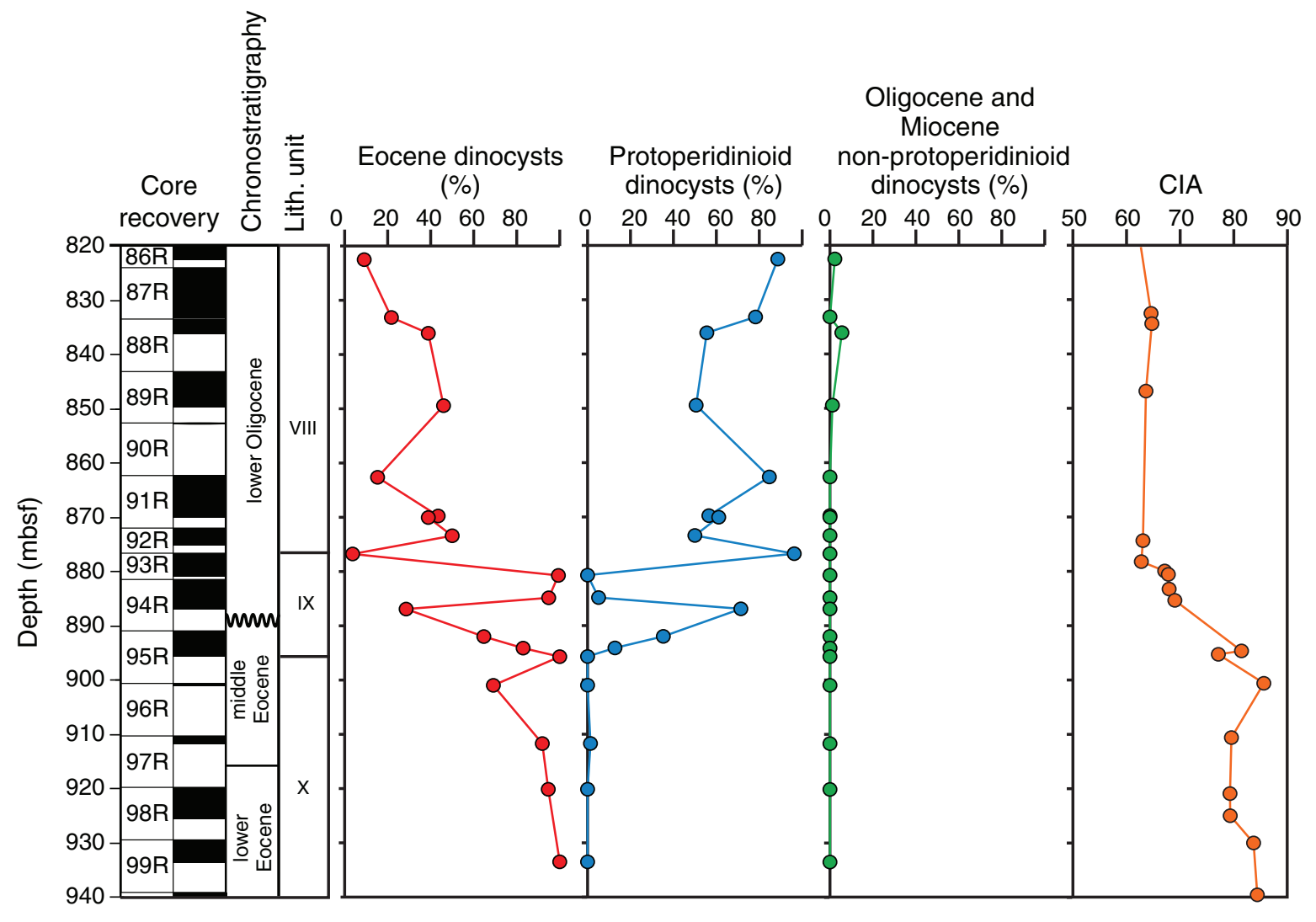


Figure F16. Core recovery and archive-half remanence data, Hole U1356A. A. Cores 318-U1356A-14R through 48R (124.10-453.80 mbsf). (Continued on next four pages.)

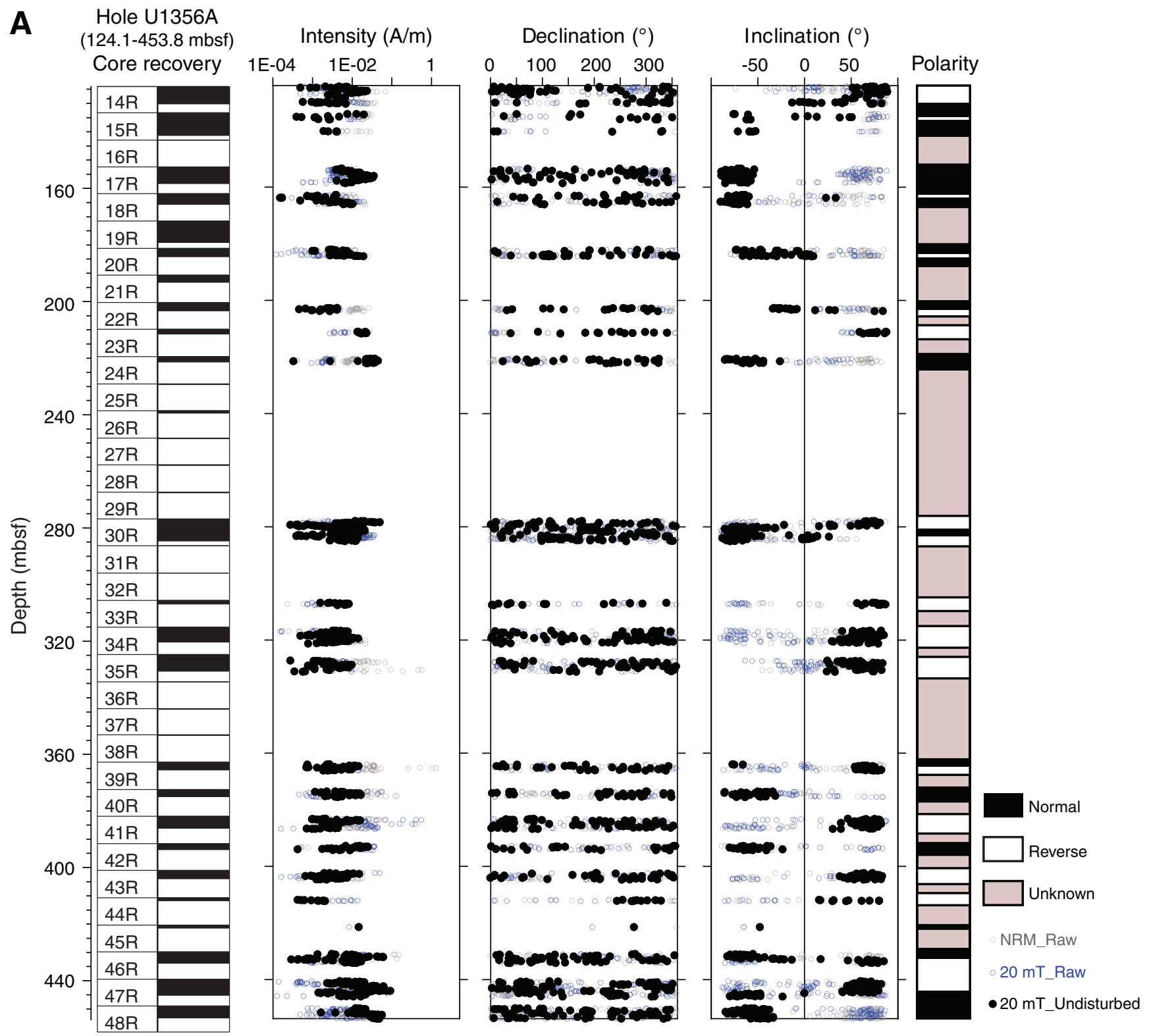


Figure F16 (continued). B. Cores 318-U1356A-49R through 65R (459.40-612.7 mbsf). (Continued on next page.)

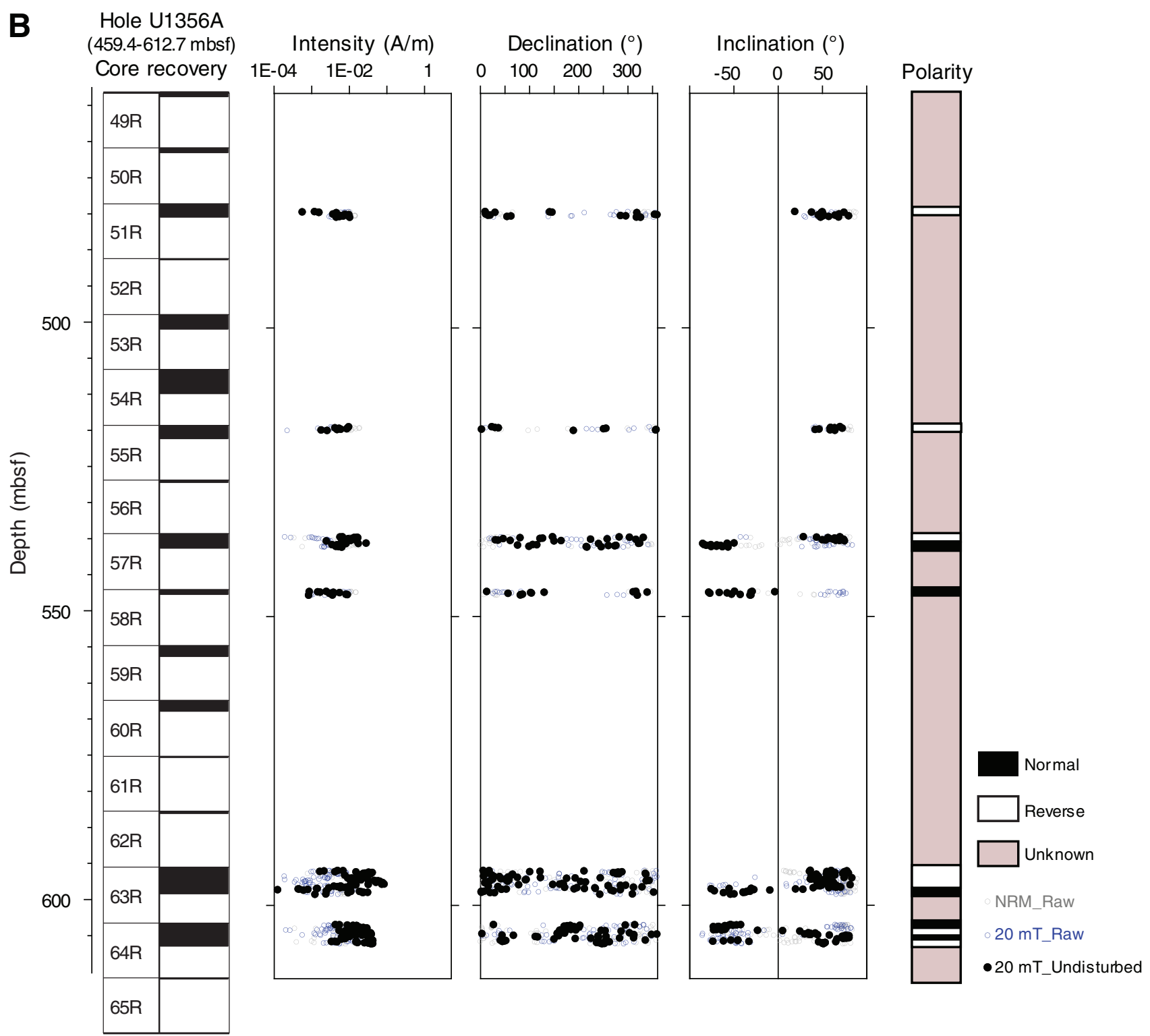


Figure F16 (continued). C. Cores 318-U1356A-66R through 90R (622.30-852.90 mbsf). (Continued on next page.)

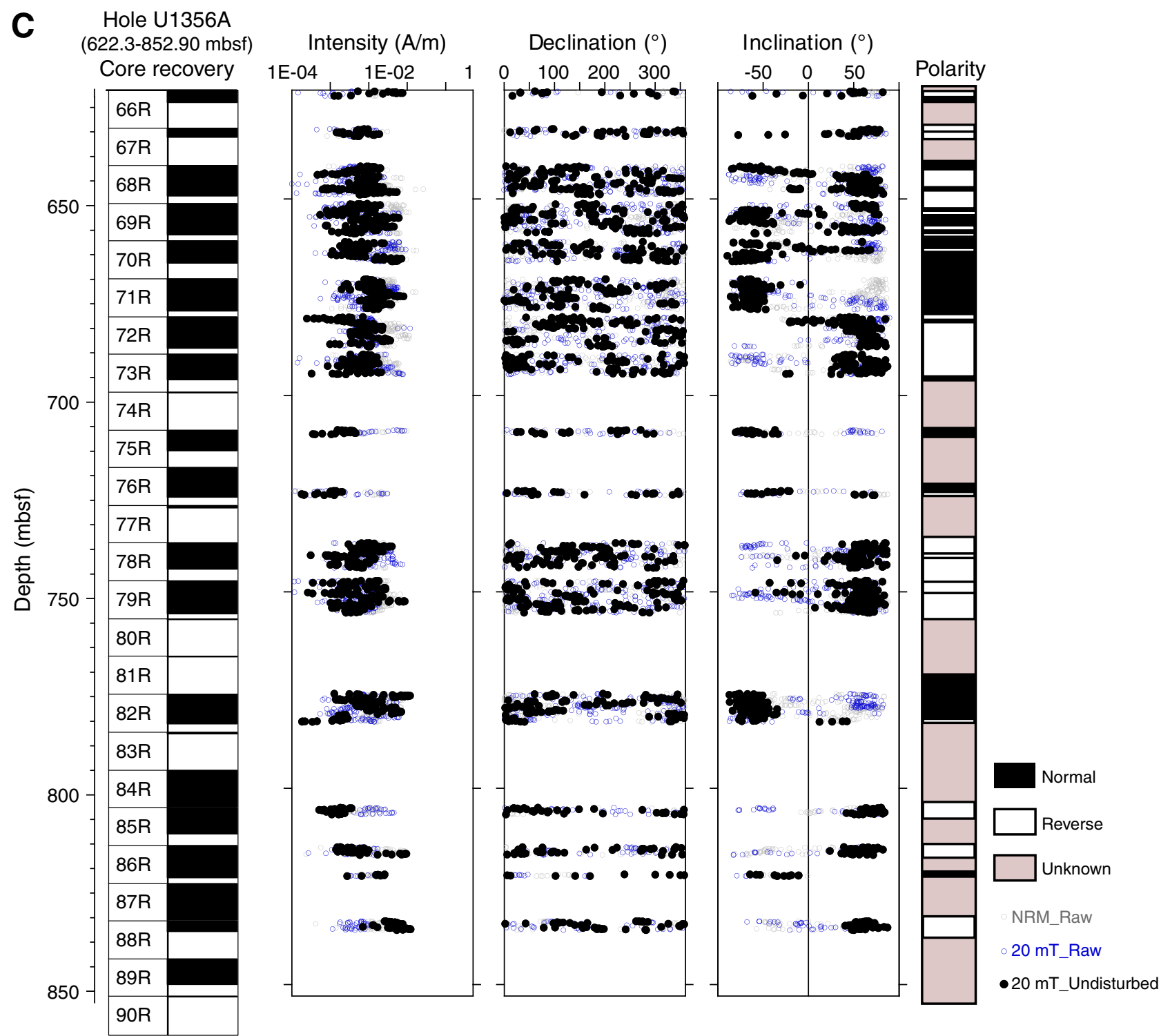


Figure F16 (continued). D. Cores 318-U1356A-91R through 98R (862.30-955.05 mbsf). (Continued on next page.)

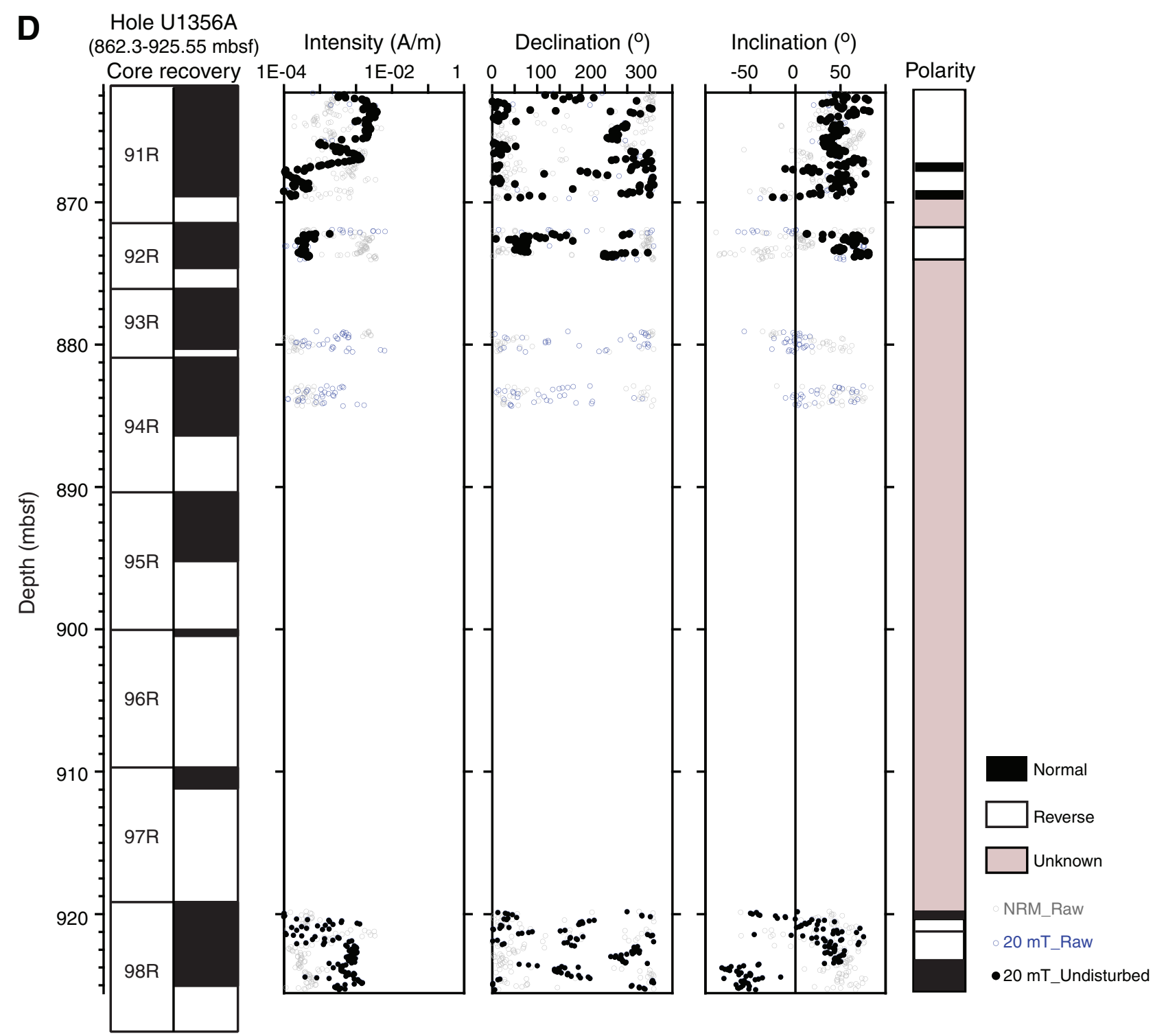


Figure F16 (continued). E. Cores 318-U1356A-99R through 106R (929.40-999.48 mbsf).

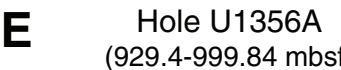

Intensity $(A / m)$
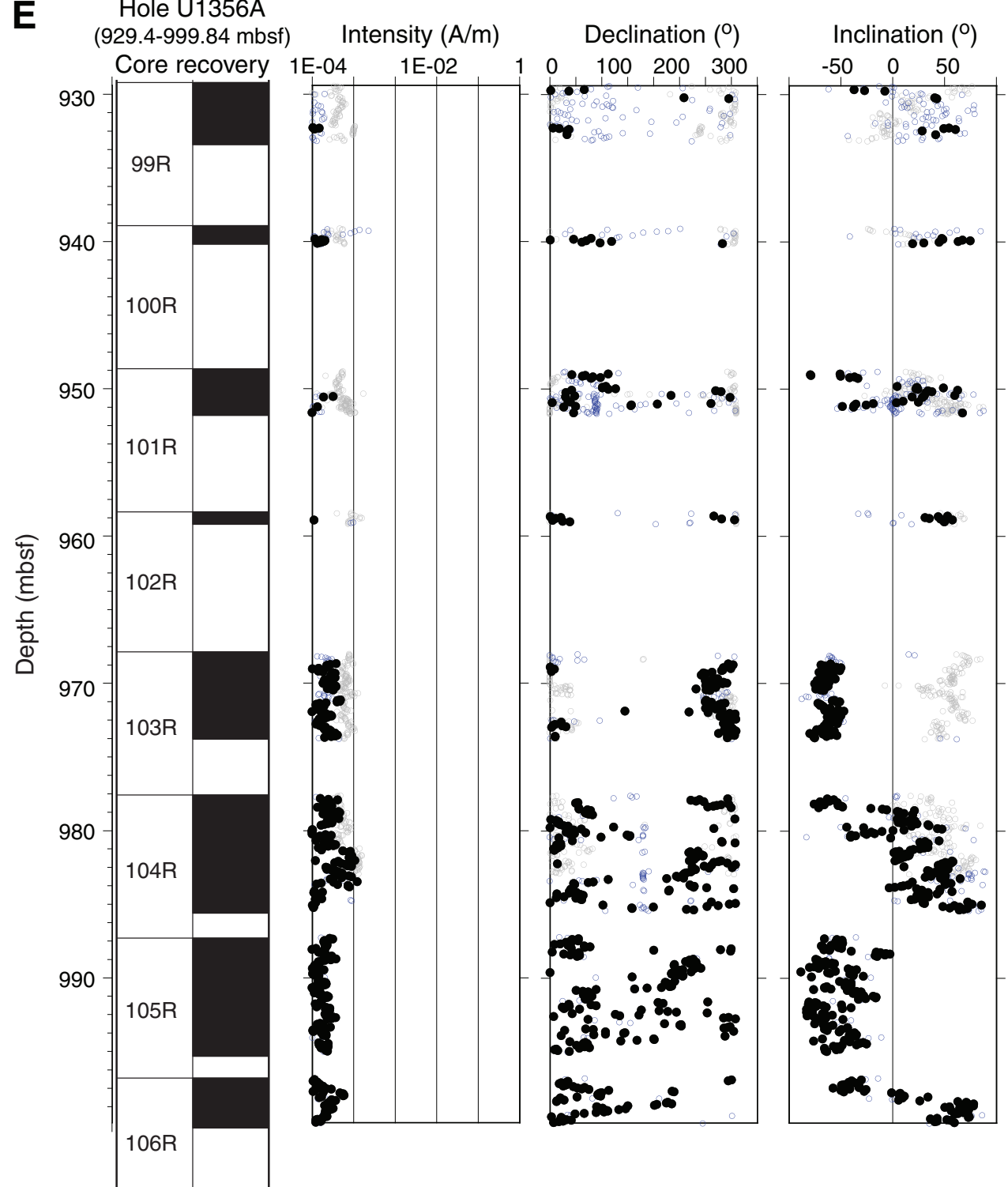

Polarity

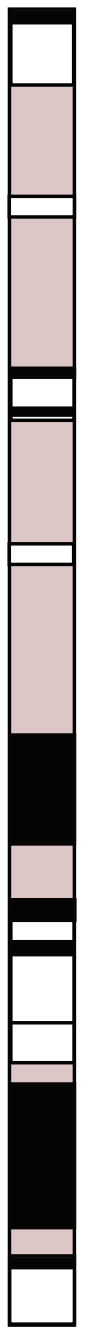

Normal

Reverse

Unknown

NRM_Raw

- 20 mT_Raw

- 20 mT_Undisturbed 
Figure F17. Results from anisotropy of magnetic susceptibility and bulk susceptibility measurements, Hole U1356A. A. Maximum (squares), intermediate (triangles), and minimum (circles) eigenvalues. The larger the separation of maximum and minimum values, the greater the degree of anisotropy. The smaller the separation of intermediate and maximum values, the more oblate the fabric. B. Inclination of the eigenvector associated with the minimum eigenvalue $\left(\mathrm{V}_{3}\right)$. Sedimentary fabrics are expected to have near-vertical $\mathrm{V}_{3}$ inclinations. C. Variation of bulk susceptibility (volume normalized) vs. depth.

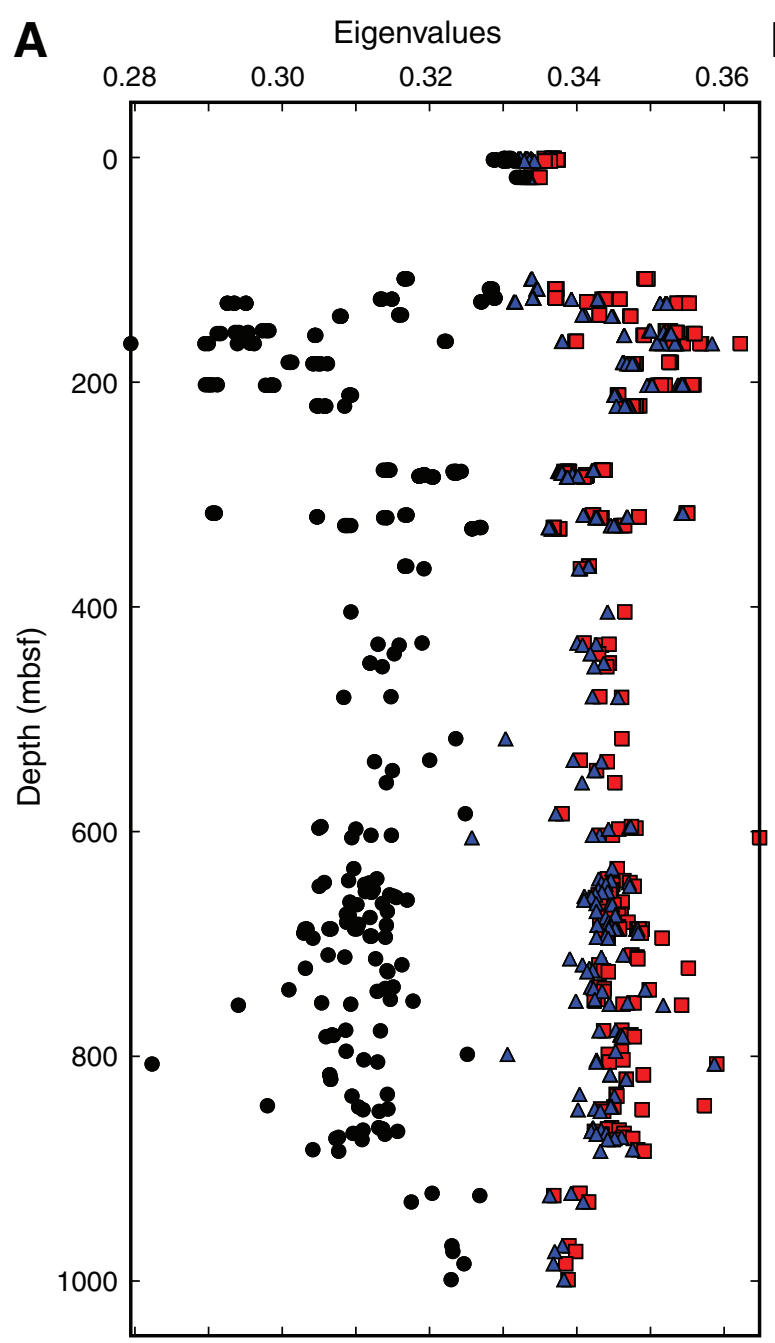

B

$\mathrm{V}_{3}$ Inclination $\left({ }^{\circ}\right.$ )

C

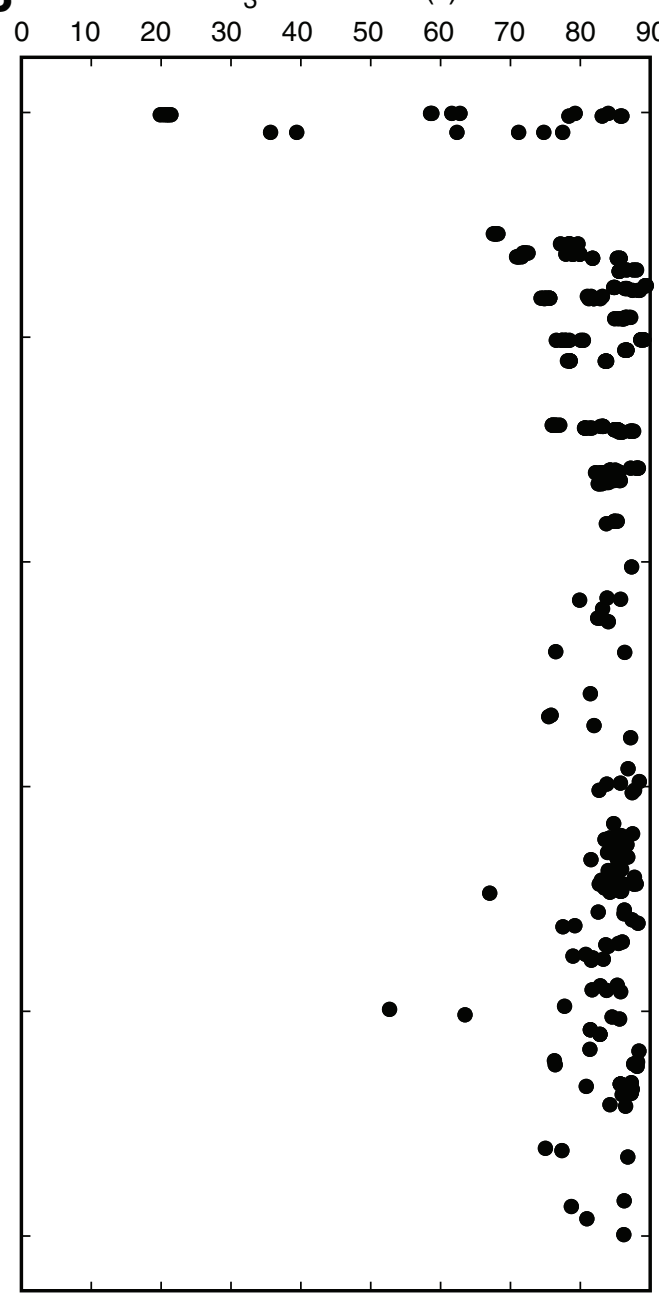

Bulk susceptibility $(\mu \mathrm{SI})$

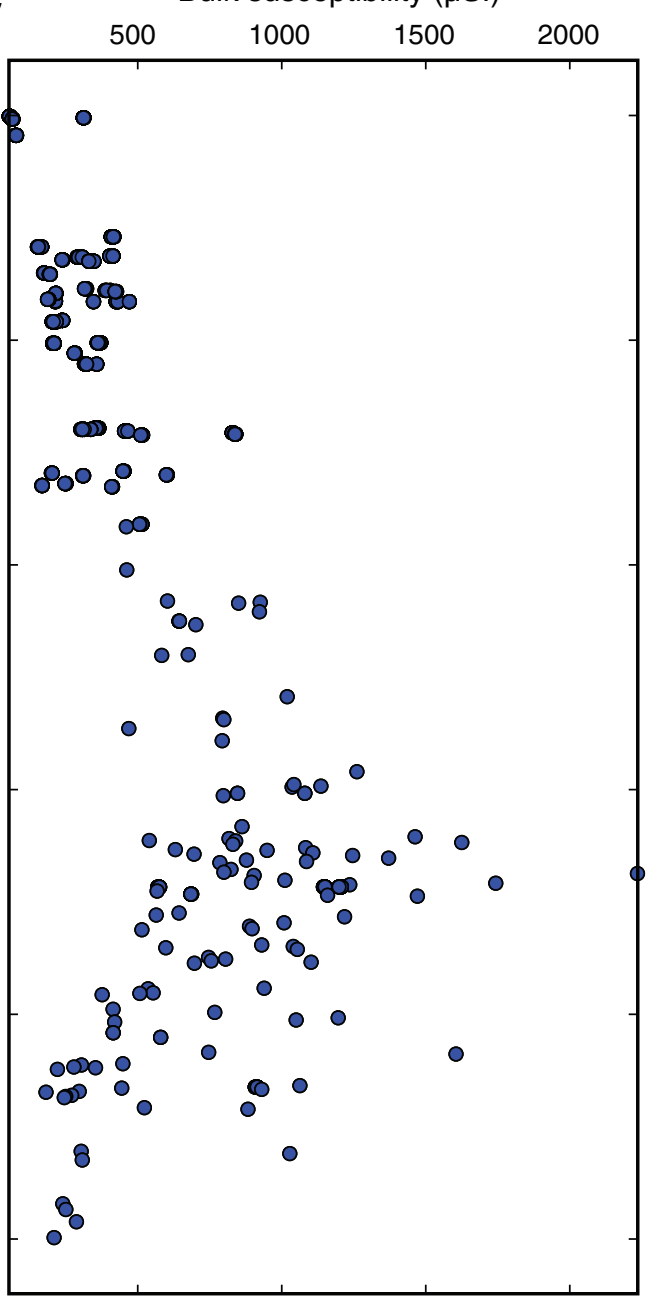


Figure F18. Example of paleomagnetic data editing procedure, Hole U1356A. A-C. Intensity, declination, and inclination of NRM after demagnetization to $20 \mathrm{mT}$ as a function of depth. D-F. Portions of high-resolution core photograph (brightness enhanced by $75 \%$ ) detailing (D) microfaults (red lines), (E) a contorted bedding plane, and (F) primary sedimentary fabric.

A Intensity $\left(10^{8} \mathrm{Am}^{2}\right)$

$$
0.0
$$

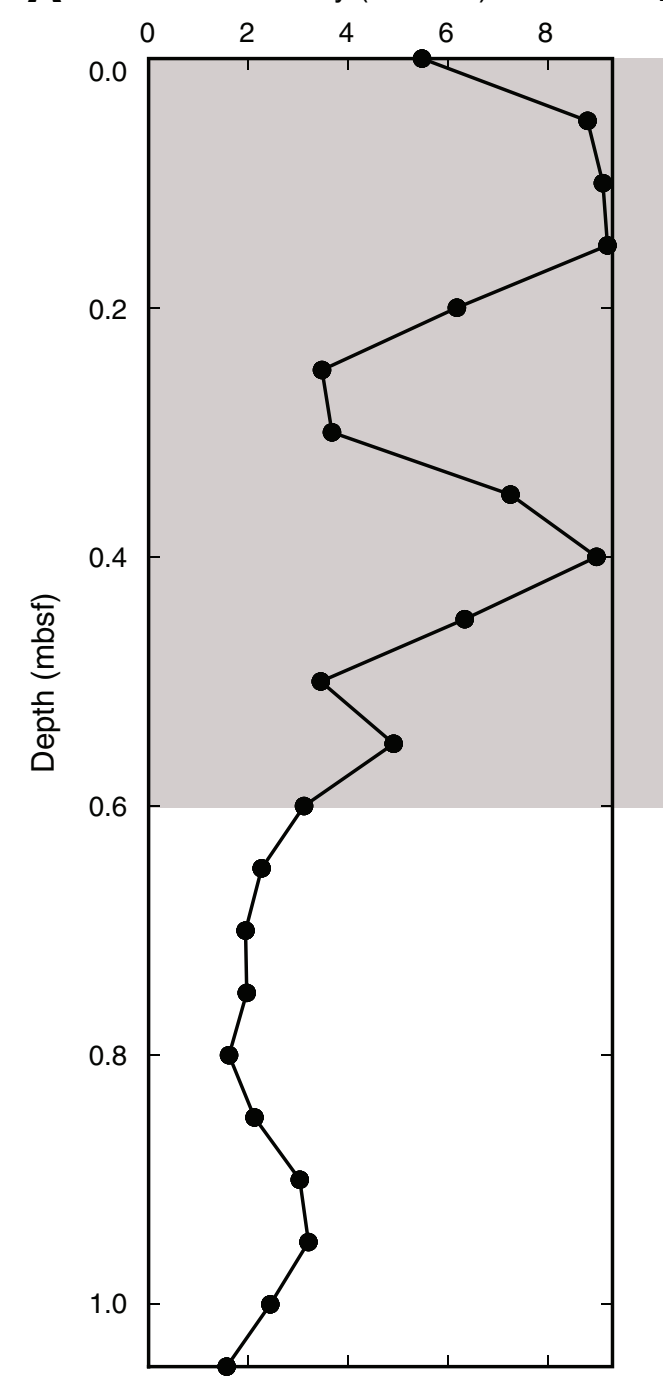

Section 318-U1356A-76R-5

B Declination $\left({ }^{\circ}\right)$

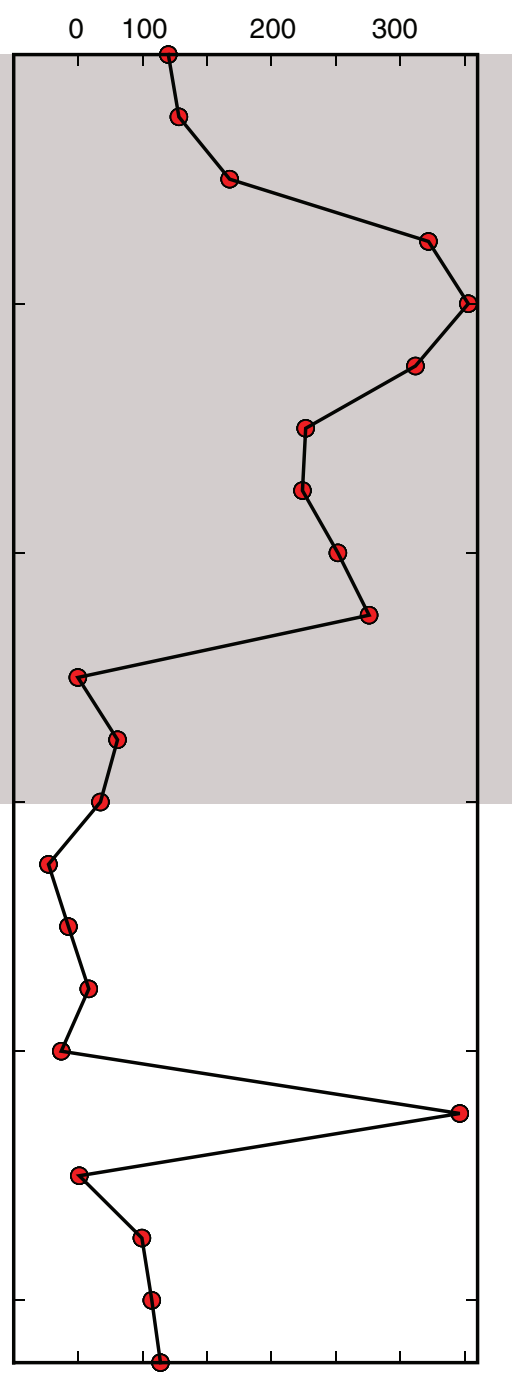

C

Inclination $\left({ }^{\circ}\right)$

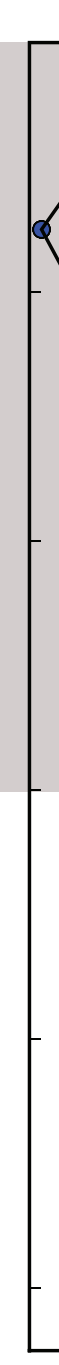

D

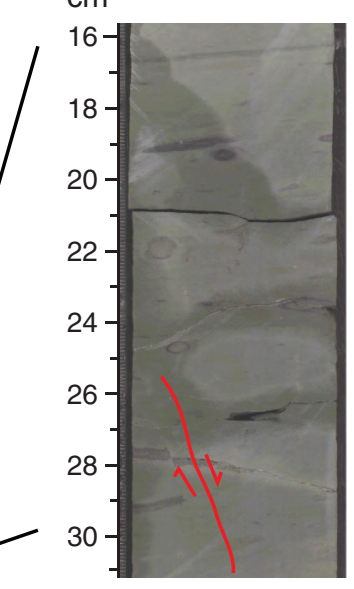

E

$\mathrm{cm}$

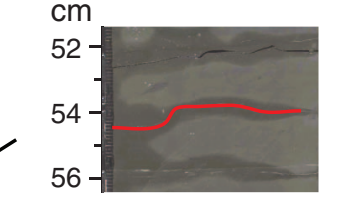

F 
Figure F19. Vector endpoint diagrams showing examples of the behavior of (A, B) normal and (C, D) reverse polarity samples during progressive demagnetization. See "Paleomagnetism" in the "Methods" chapter for description of diagrams. NRM = natural remanent magnetization, Dec = declination.

A

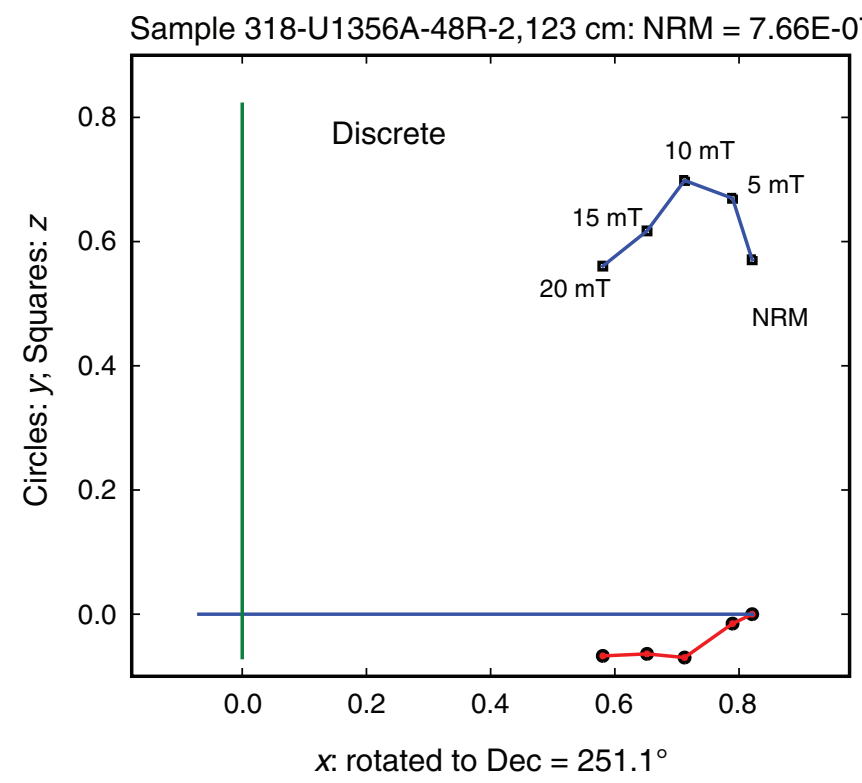

C

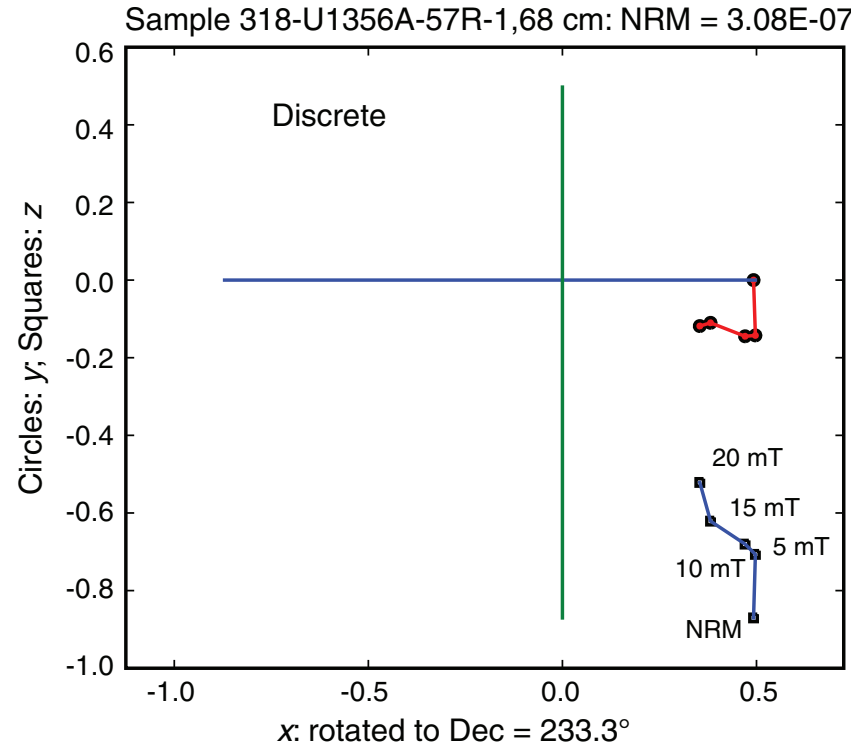

\section{B}

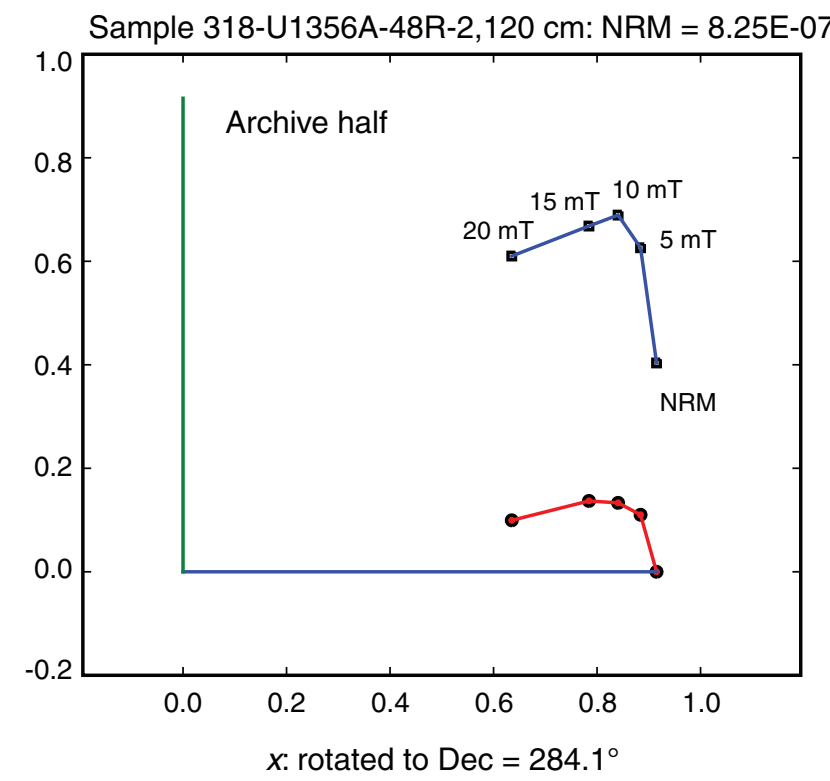

D

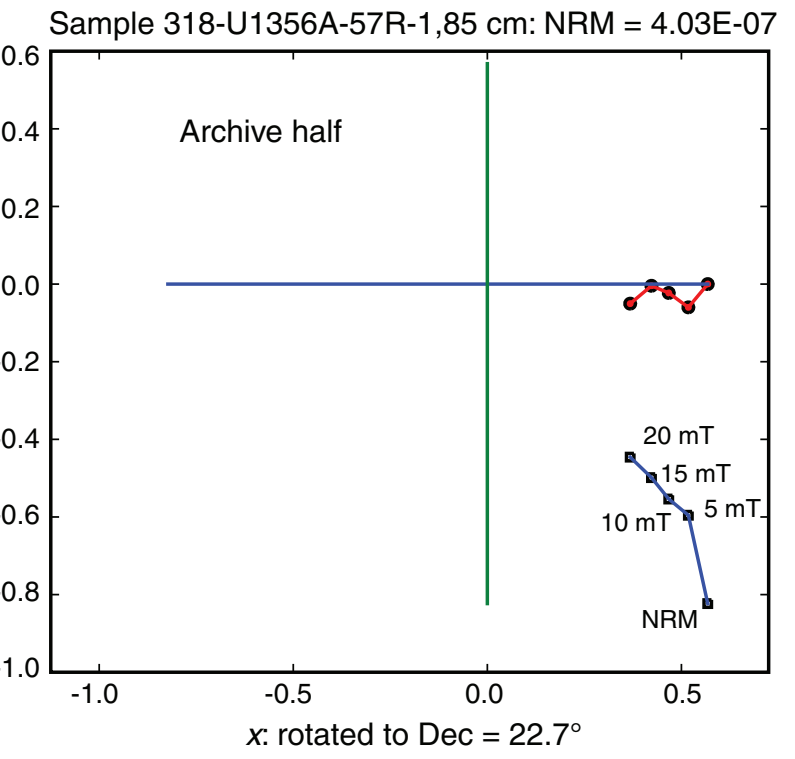


Figure F20. Histograms of inclinations, Hole U1356A. A. Natural remanent magnetization (NRM) of archive halves. B. After demagnetization in alternating fields of $20 \mathrm{mT}$. C. Expected from the paleosecular variation field model TK03 of Tauxe and Kent (2004) evaluated at latitude $60^{\circ}$.
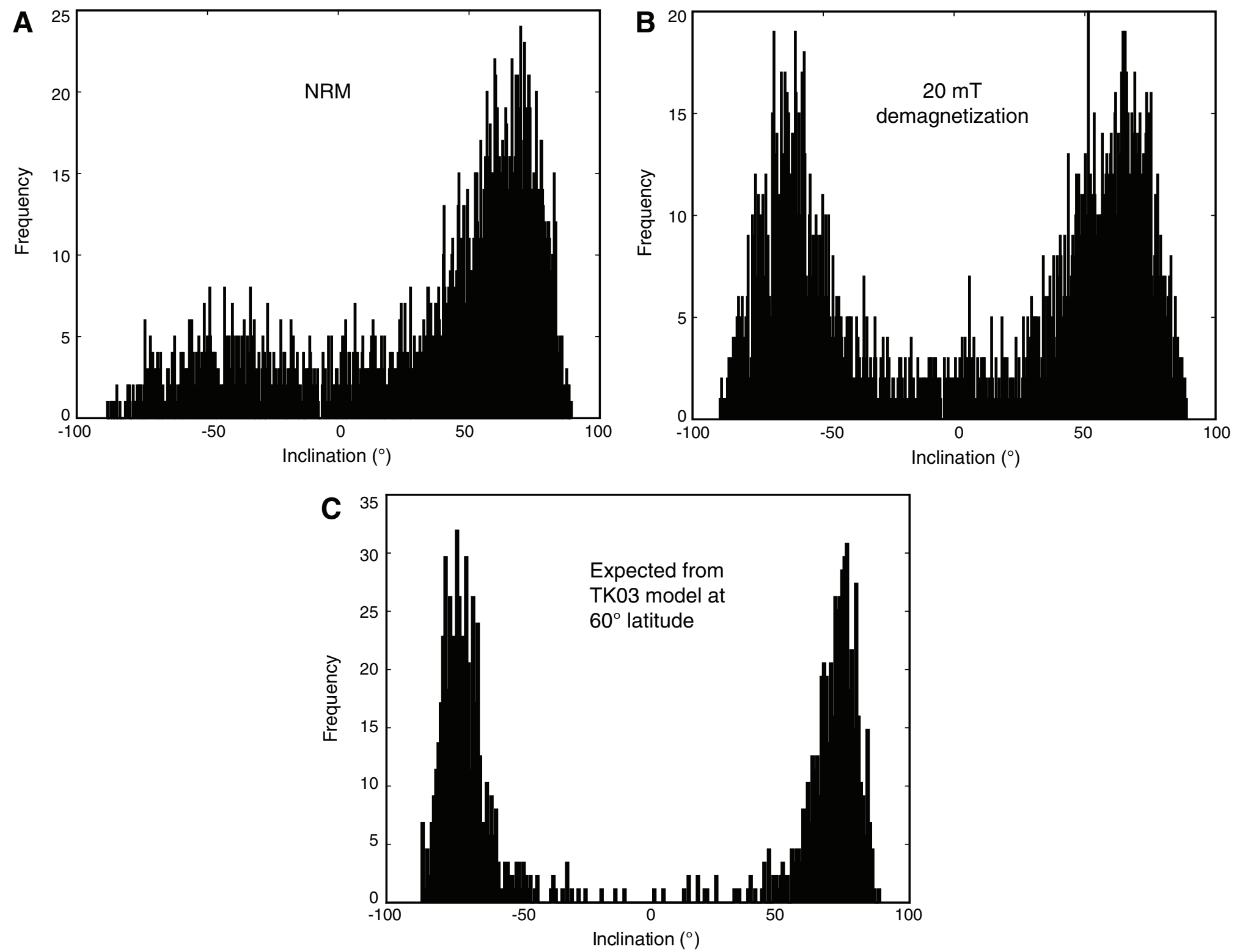
Figure F21. Correlation of magnetostratigraphy in Hole U1356A to the geomagnetic polarity timescale of Gradstein et al. (2004) (see Table T5 in the "Methods" chapter). Left panels are the inclinations from Figure F16 after demagnetization to $20 \mathrm{mT}$ and edited as described in the text. Tie points identified in Table T1 are shown. A. Cores 318-U1356A-14R through 51R. Solid circles = data from archives, open squares = data from discrete samples. (Continued on next two pages.)

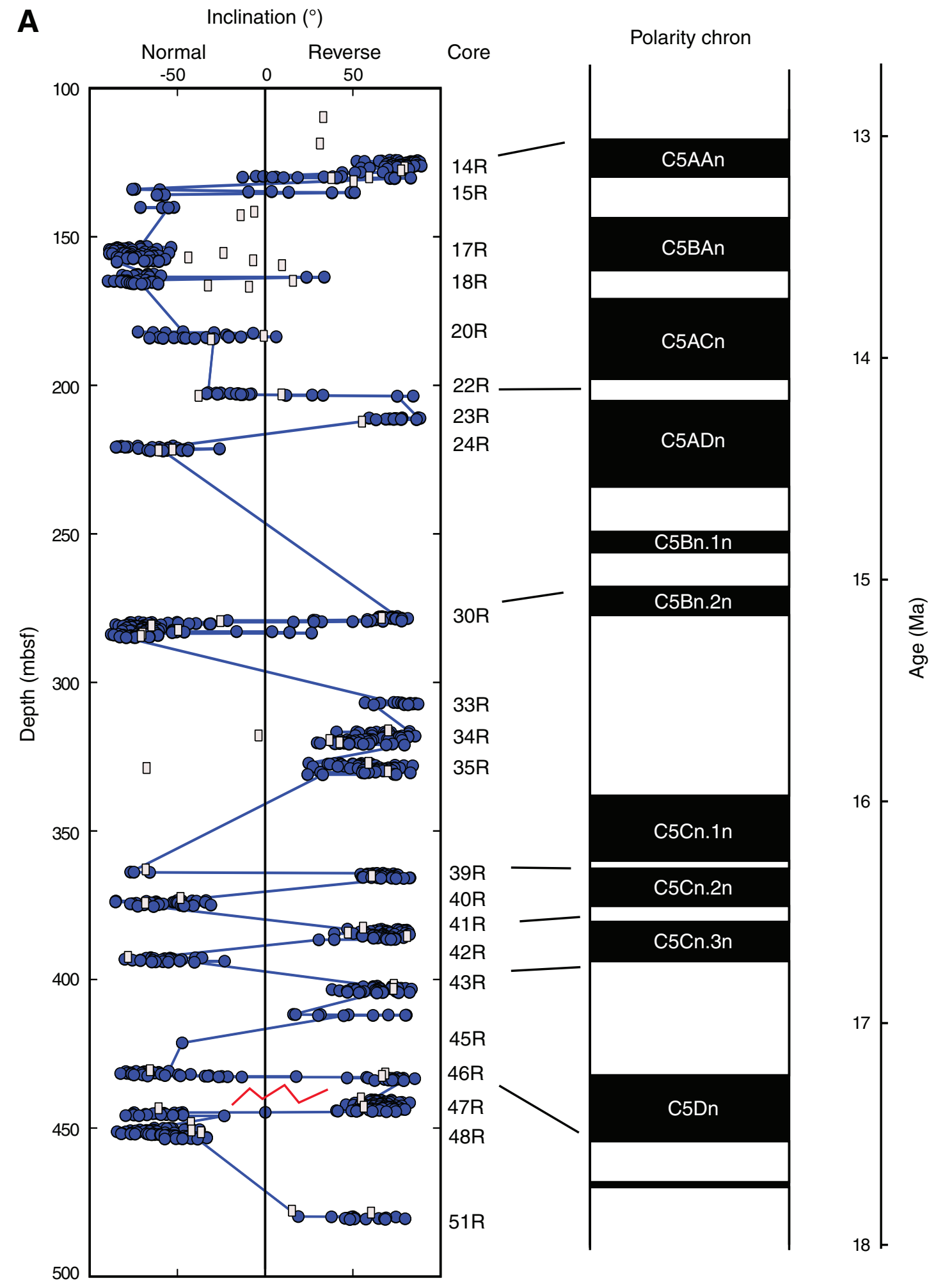


Figure F21 (continued). B. Cores 318-U1356A-68R through 92R. (Continued on next page.)

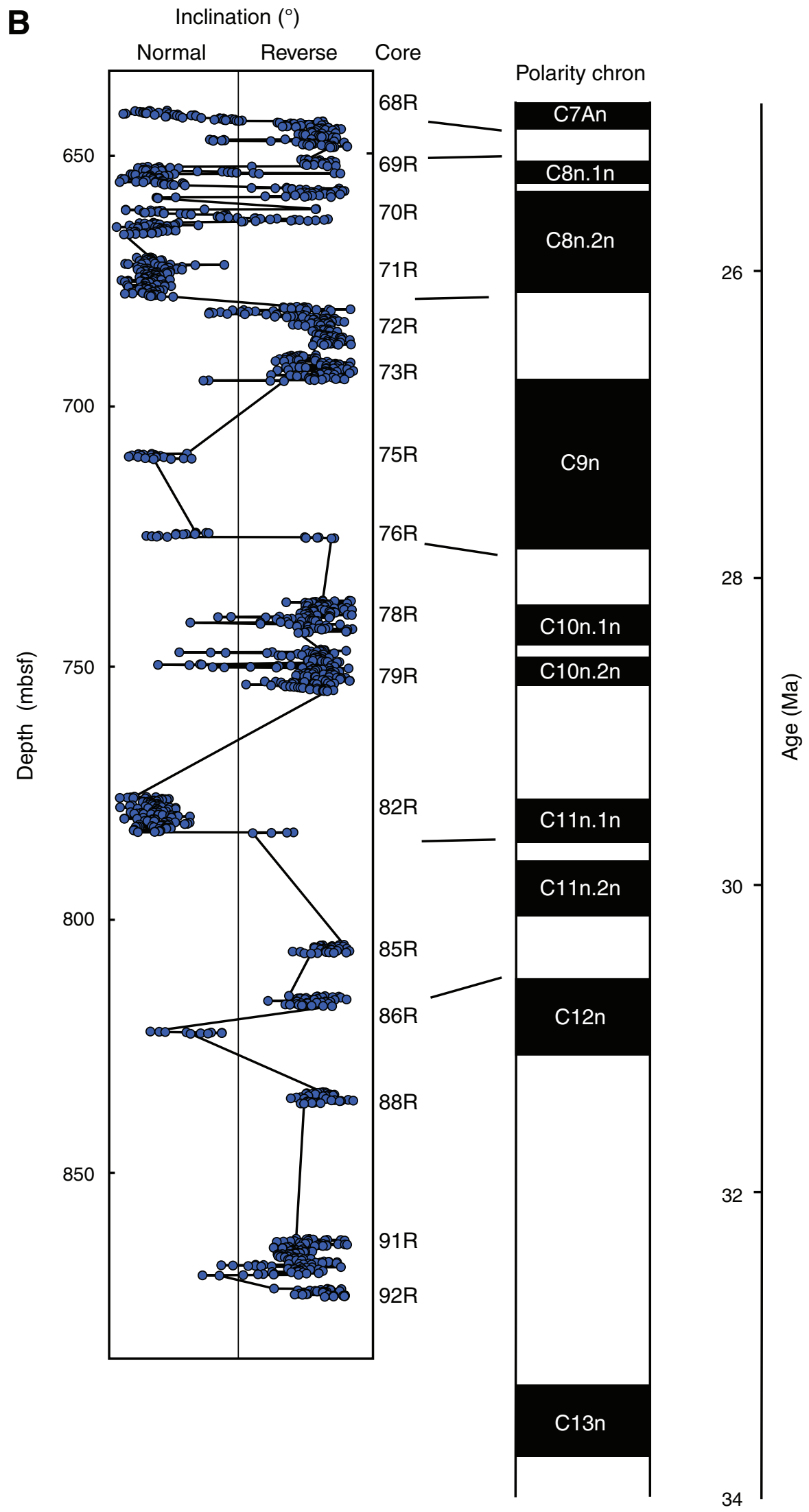


Figure F21 (continued). C. Cores 318-U1356A-99R through 106R.

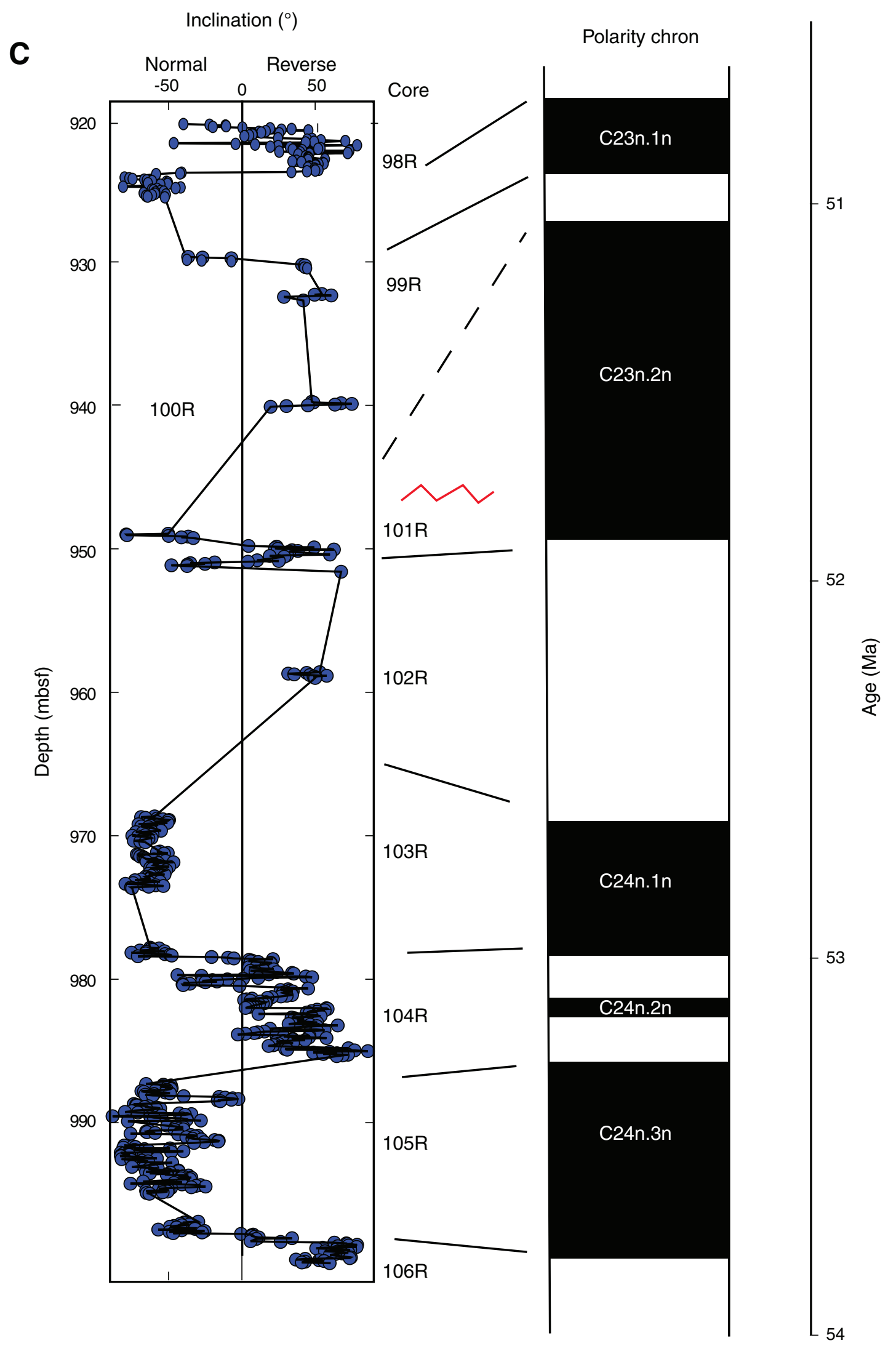


Figure F22. (A) Methane concentrations and (B) methane/ethane ratios, Hole U1356A.

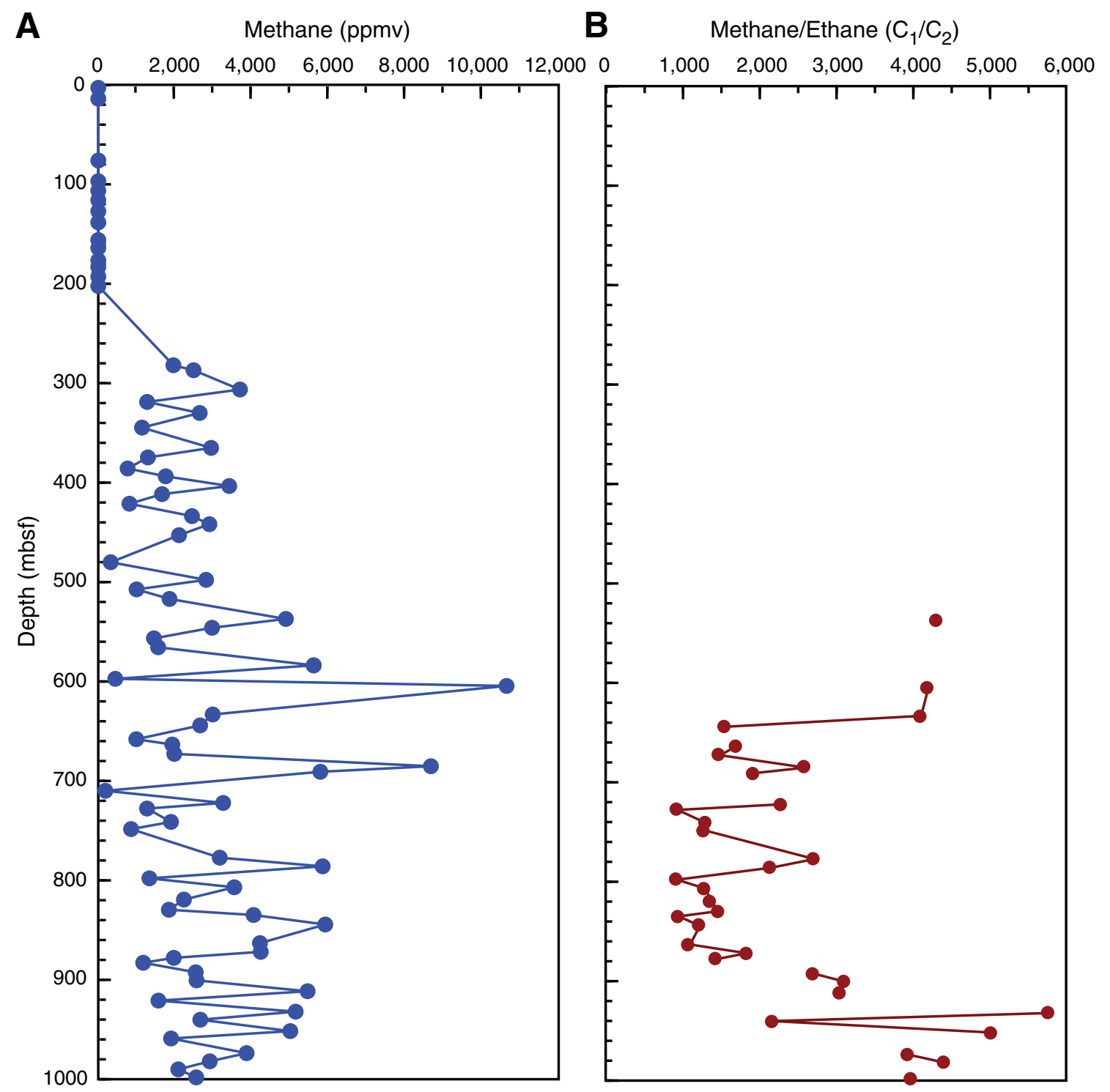


Figure F23. Lipid biomarkers in Sample 318-U1356A-15R-3, 83-84 cm (137.63-137.64 mbsf; middle Miocene), Hole U1356A. GC-MS = gas chromatography mass spectrometry.

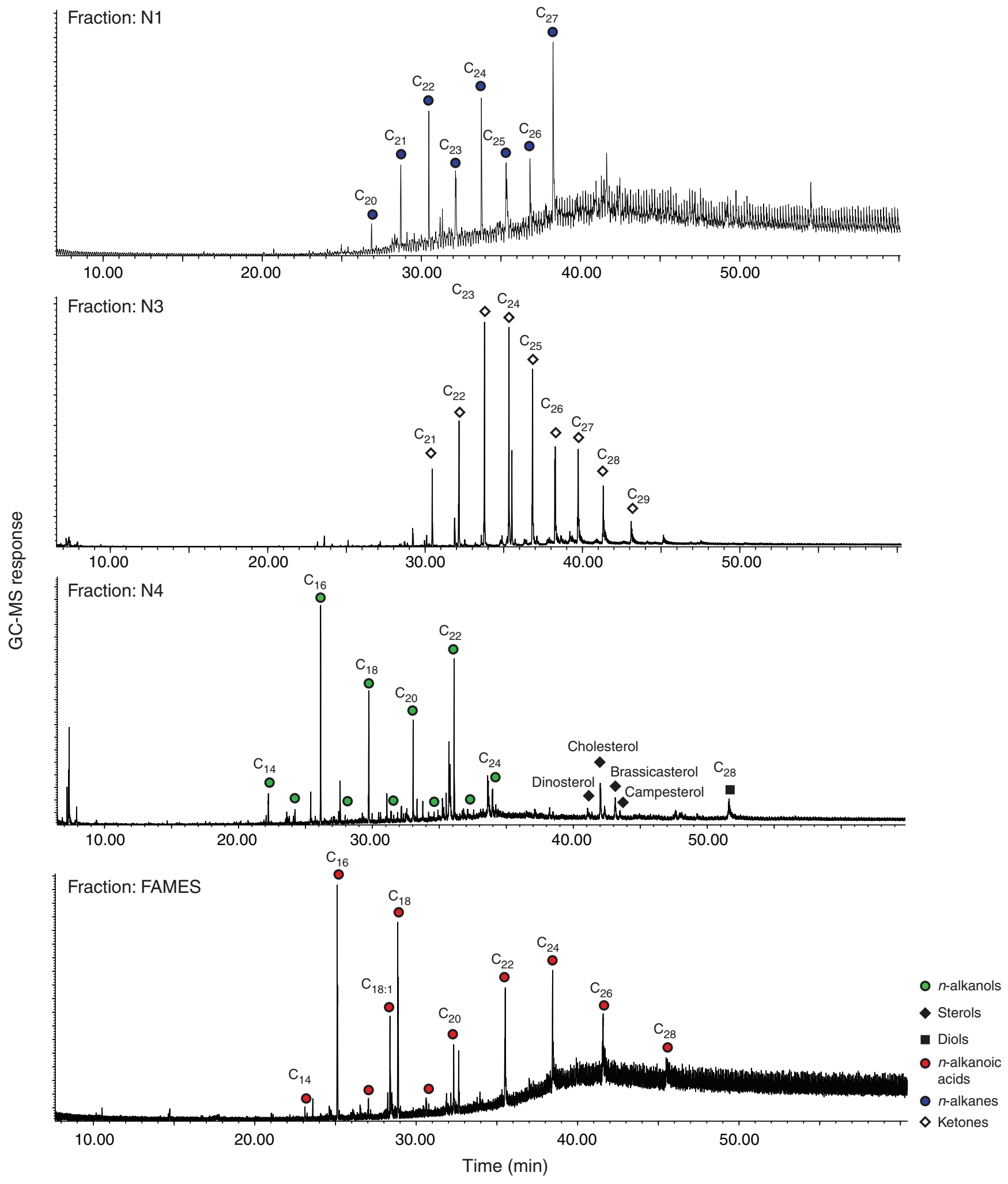


Figure F24. Lipid biomarkers in Sample 318-U1356A-63R-4, 37-39 cm (597.72-597.74 mbsf; late Oligocene), Hole U1356A. GC-MS = gas chromatography mass spectrometry, SIM = single-ion monitoring.
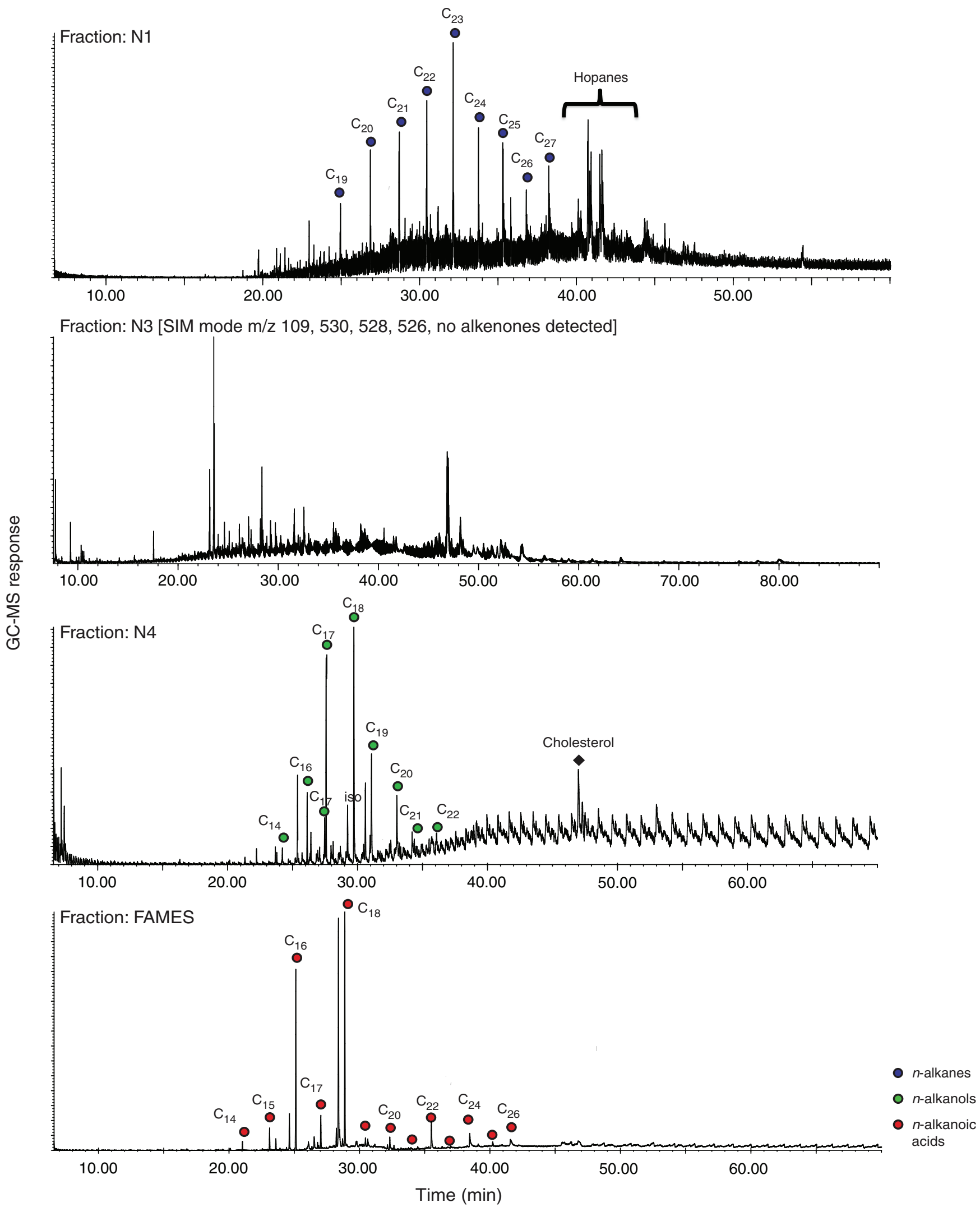
Figure F25. Lipid biomarkers in Sample 318-U1356A-101R-2, 57-59 cm (950.87-950.89 mbsf; early Eocene), Hole U1356A. GC-MS = gas chromatography mass spectrometry, SIM = single-ion monitoring.
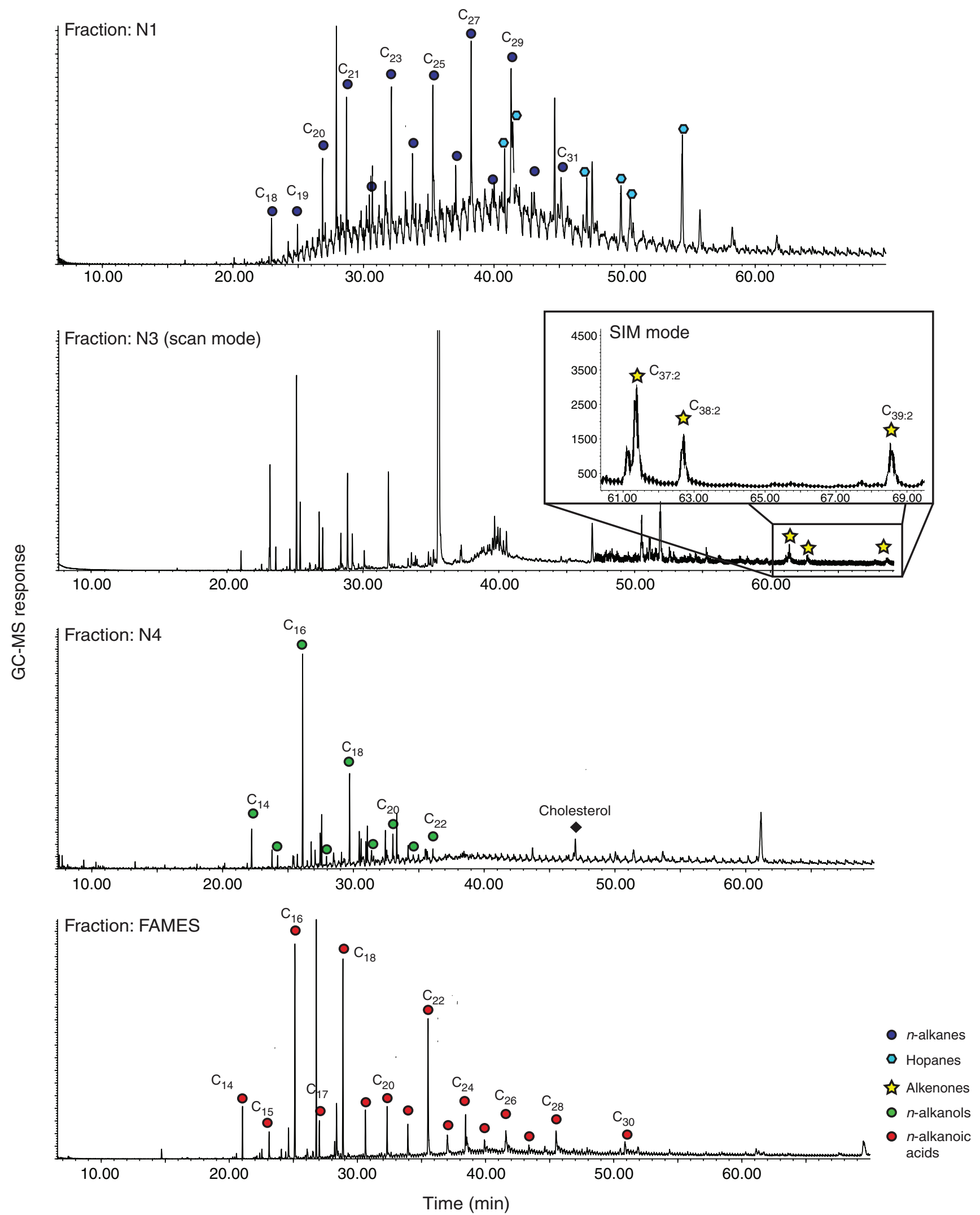
Figure F26. Lipid biomarkers in Sample 318-U1356A-103R-1, 54-56 cm (968.54-968.56 mbsf; early Eocene), Hole U1356A. GC-MS = gas chromatography mass spectrometry, SIM = single-ion monitoring.

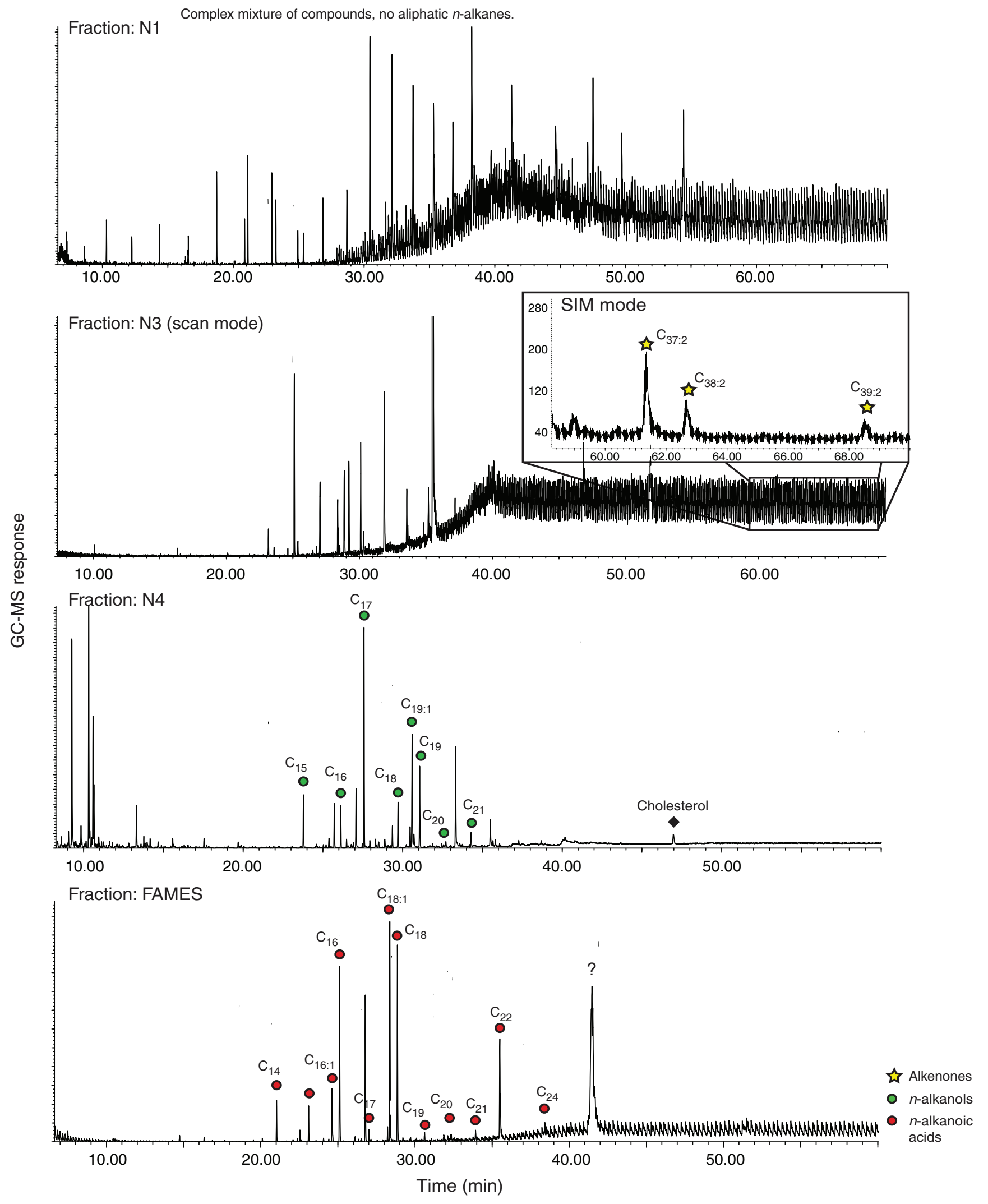


Figure F27. Calcium carbonate data, Site U1356.

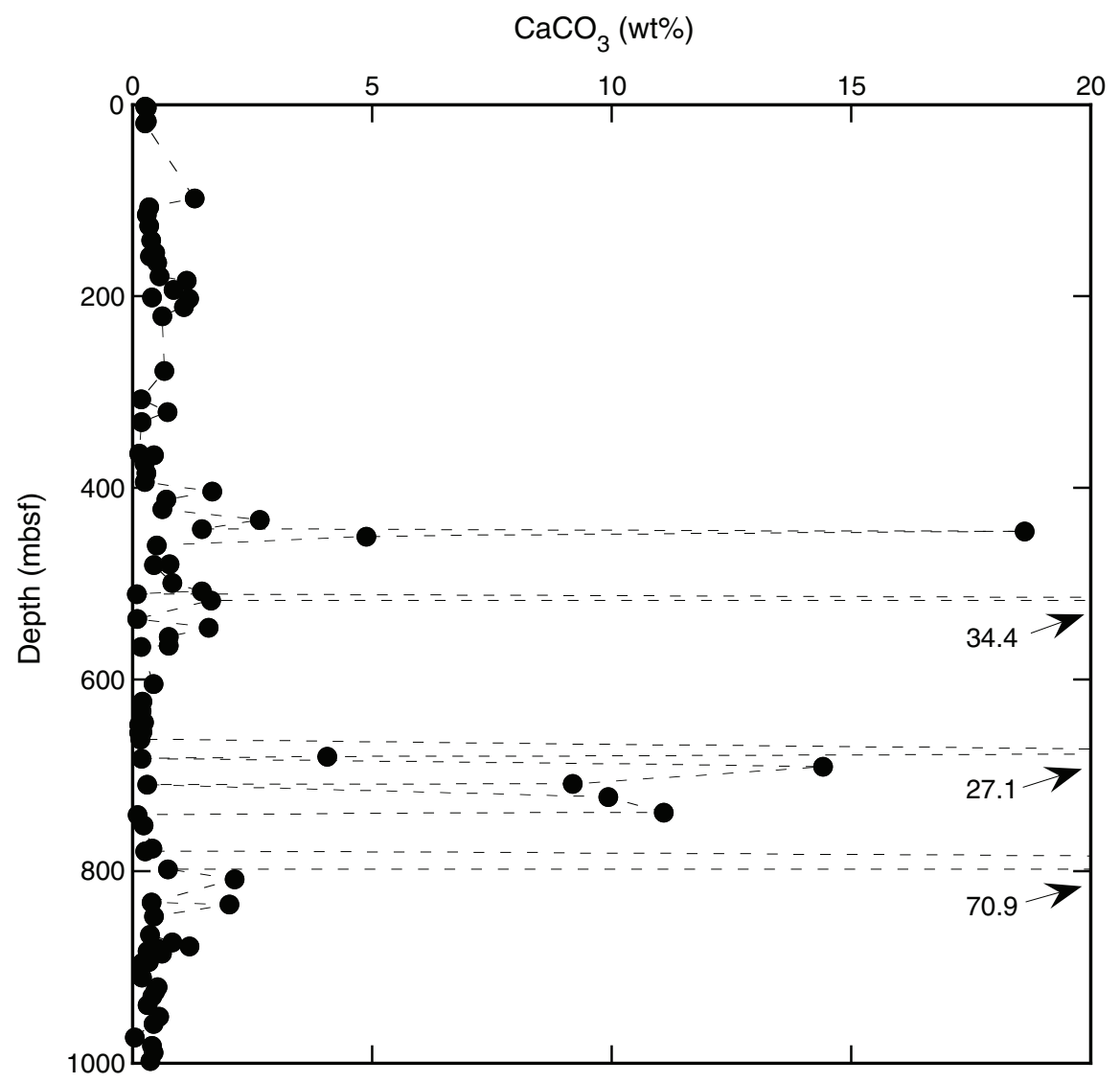


Figure F28. Bulk sediment geochemical data, Site U1356.
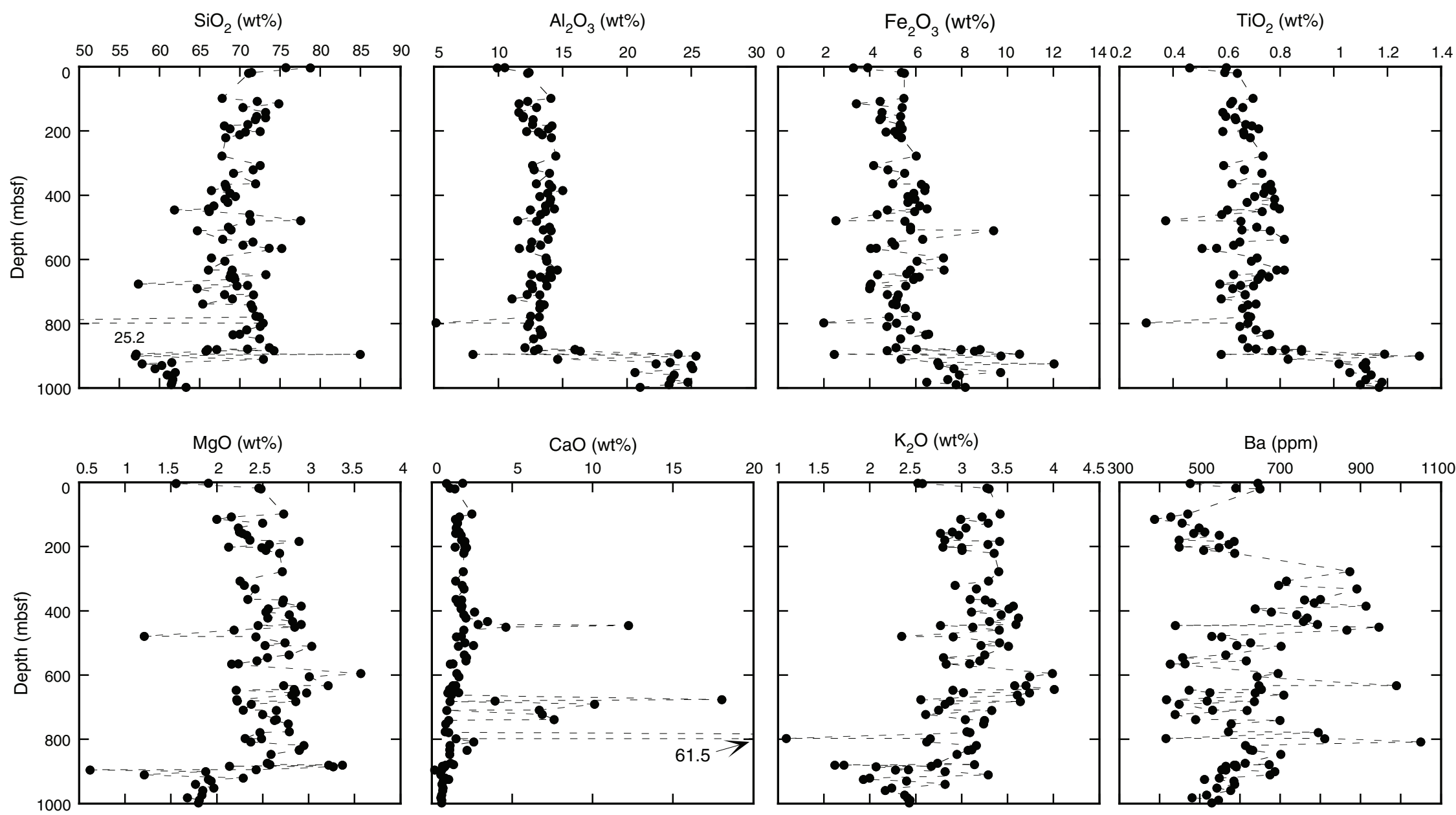
Figure F29. Chemical index of alteration (CIA) calculated for samples from Site U1356 (omitting minor and carbonate-rich lithologies and diatom oozes). For definition of CIA see main text.

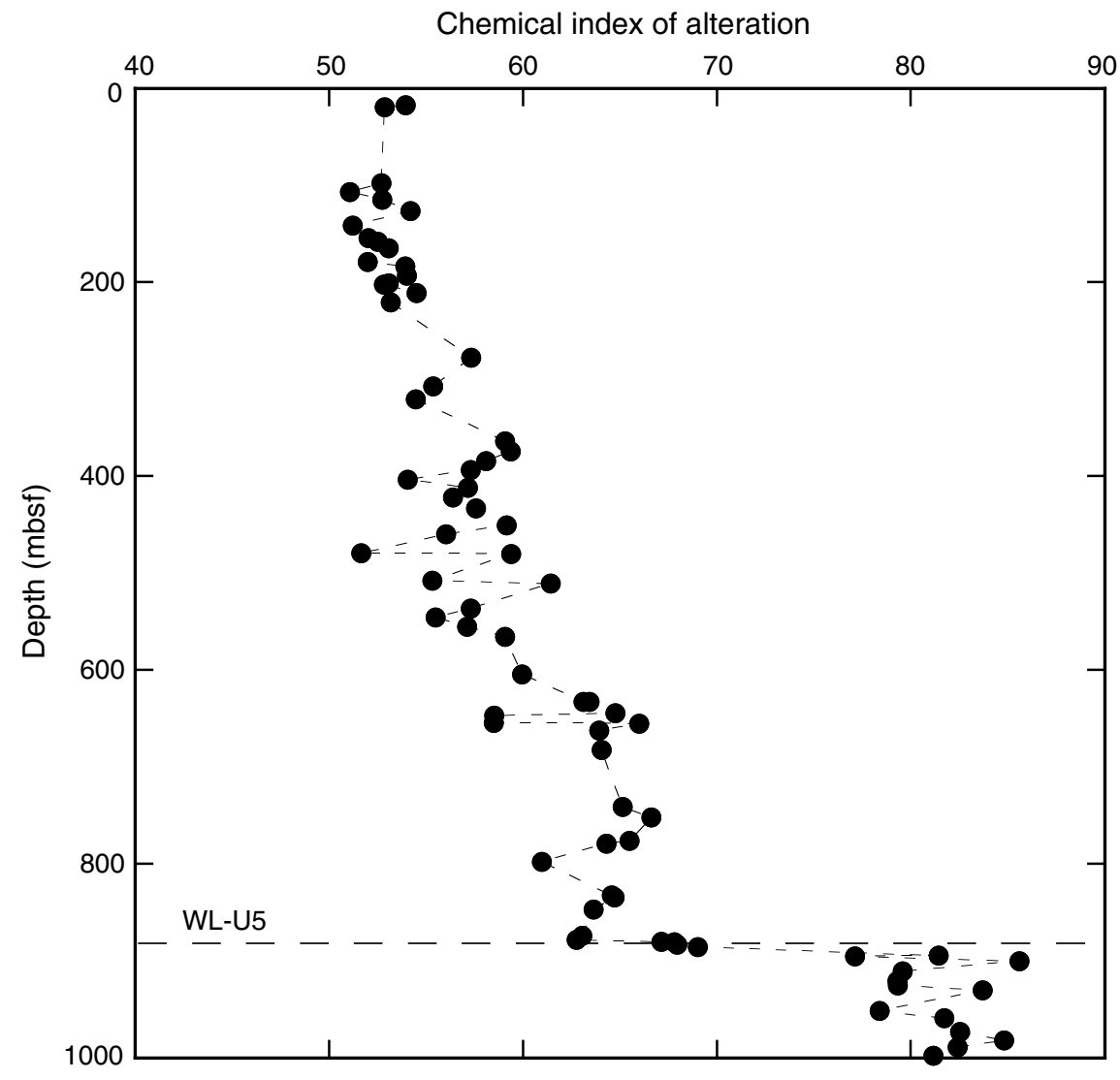


Figure F30. Magnetic susceptibility and natural gamma radiation (NGR) data, Hole U1356A.

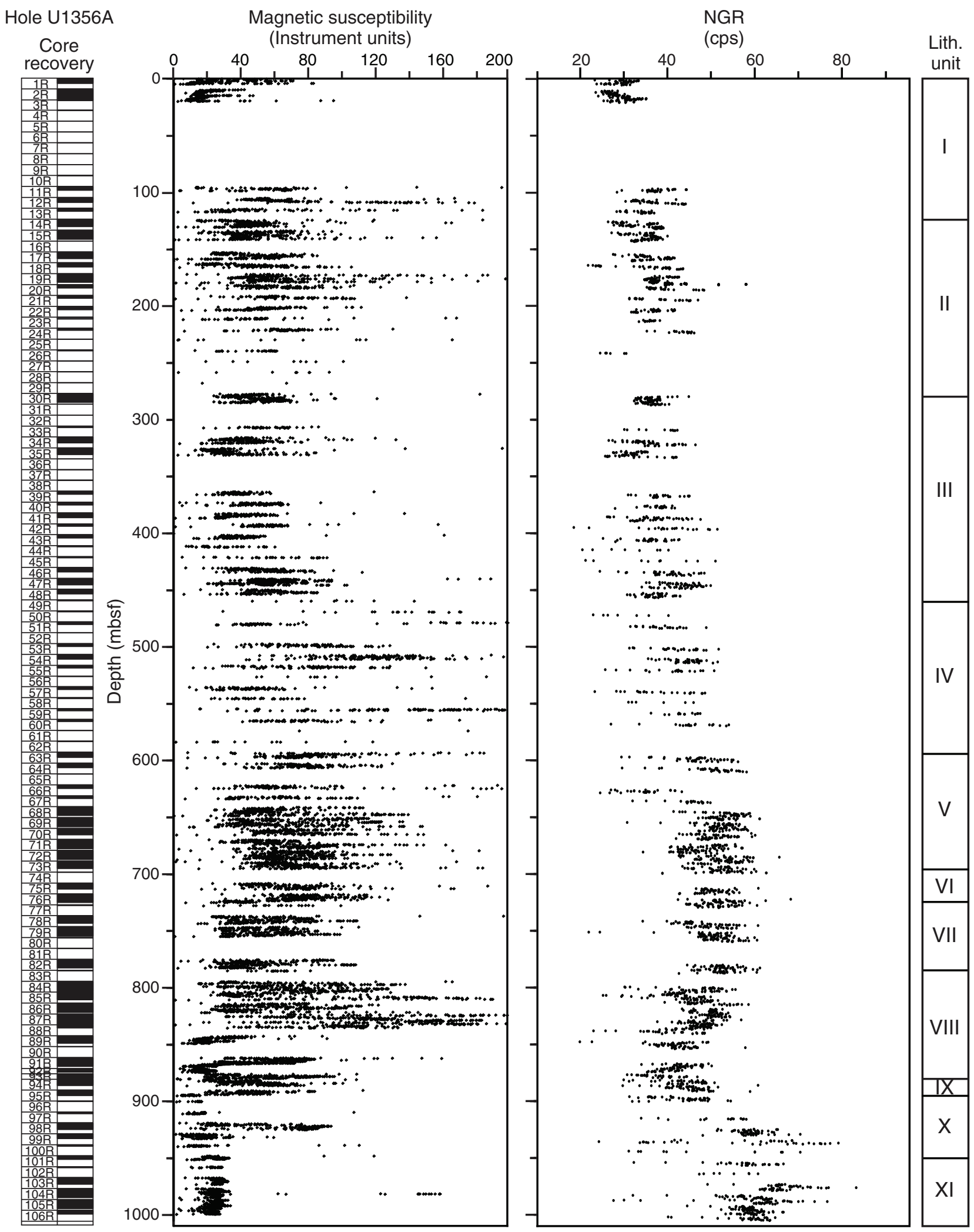


Figure F31. Gamma ray attenuation (GRA) bulk density (squares) and wet bulk density from discrete measurements (circles), Hole U1356A.

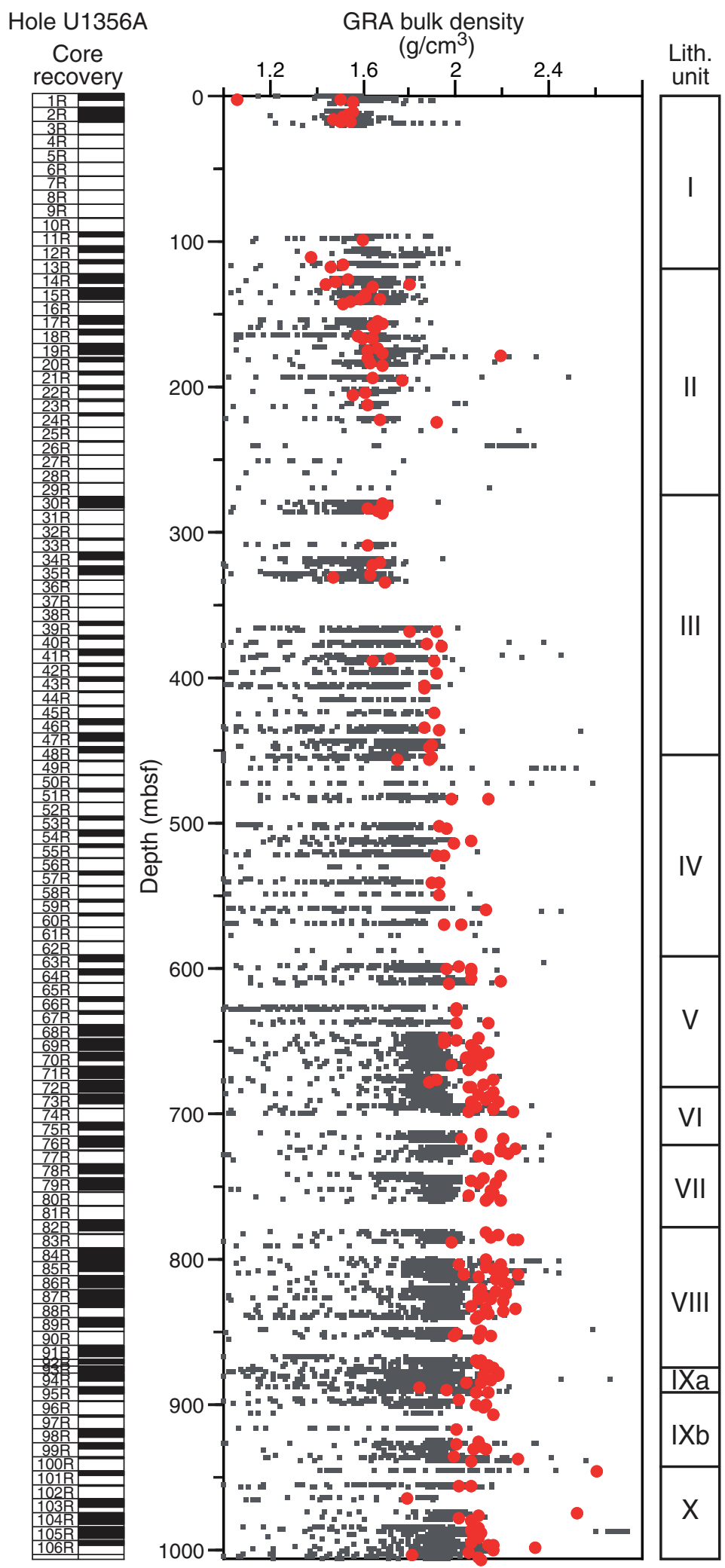


Figure F32. $P$-wave logger (PWL) and Section Half Velocity Gantry data, Hole U1356A. U5, U4, U3 = approximate position of main reflectors in the seismic section (see text) as calculated from $P$-wave velocities measured in cores.

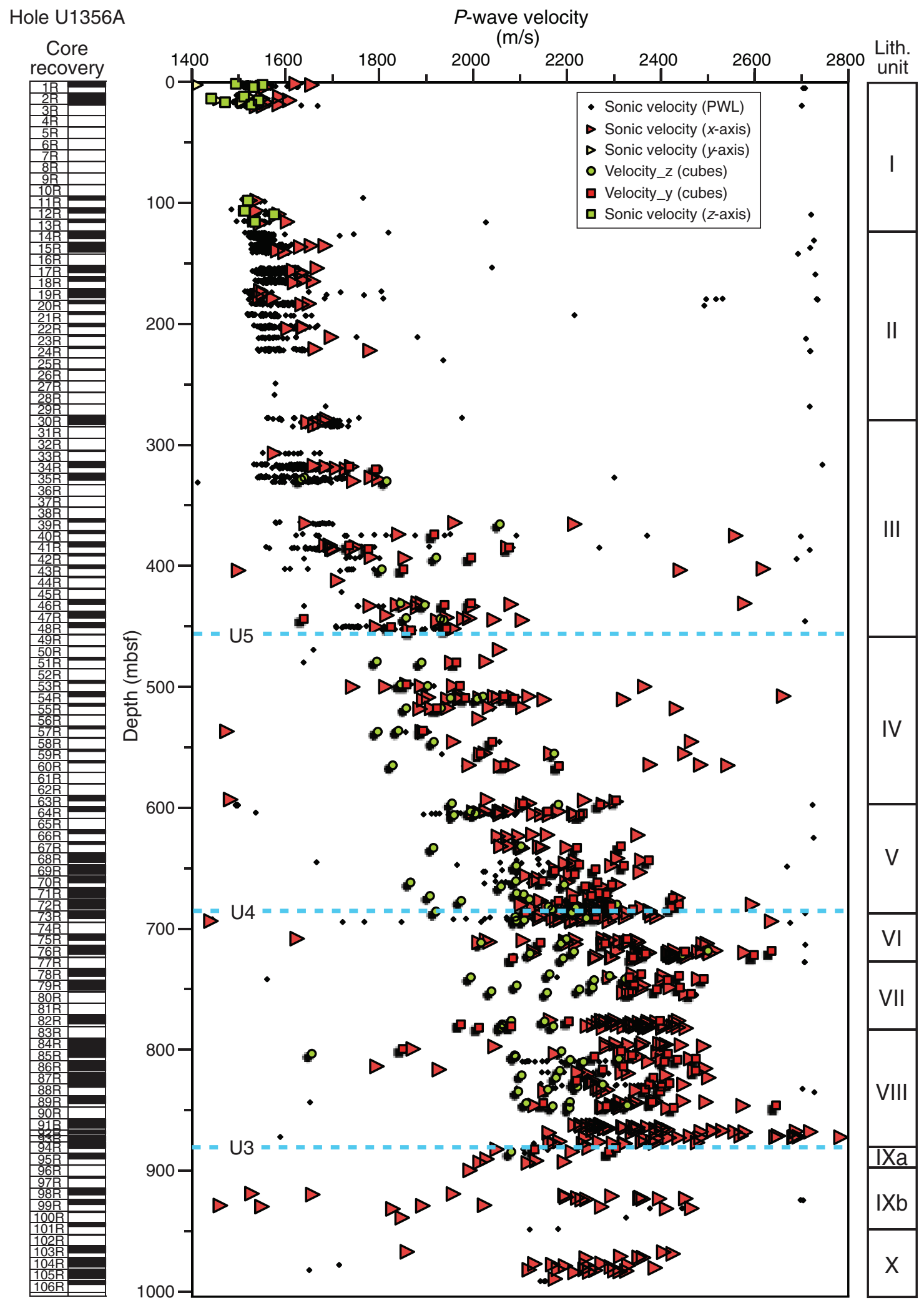


Figure F33. Grain density and porosity from discrete measurements, Hole U1356A.

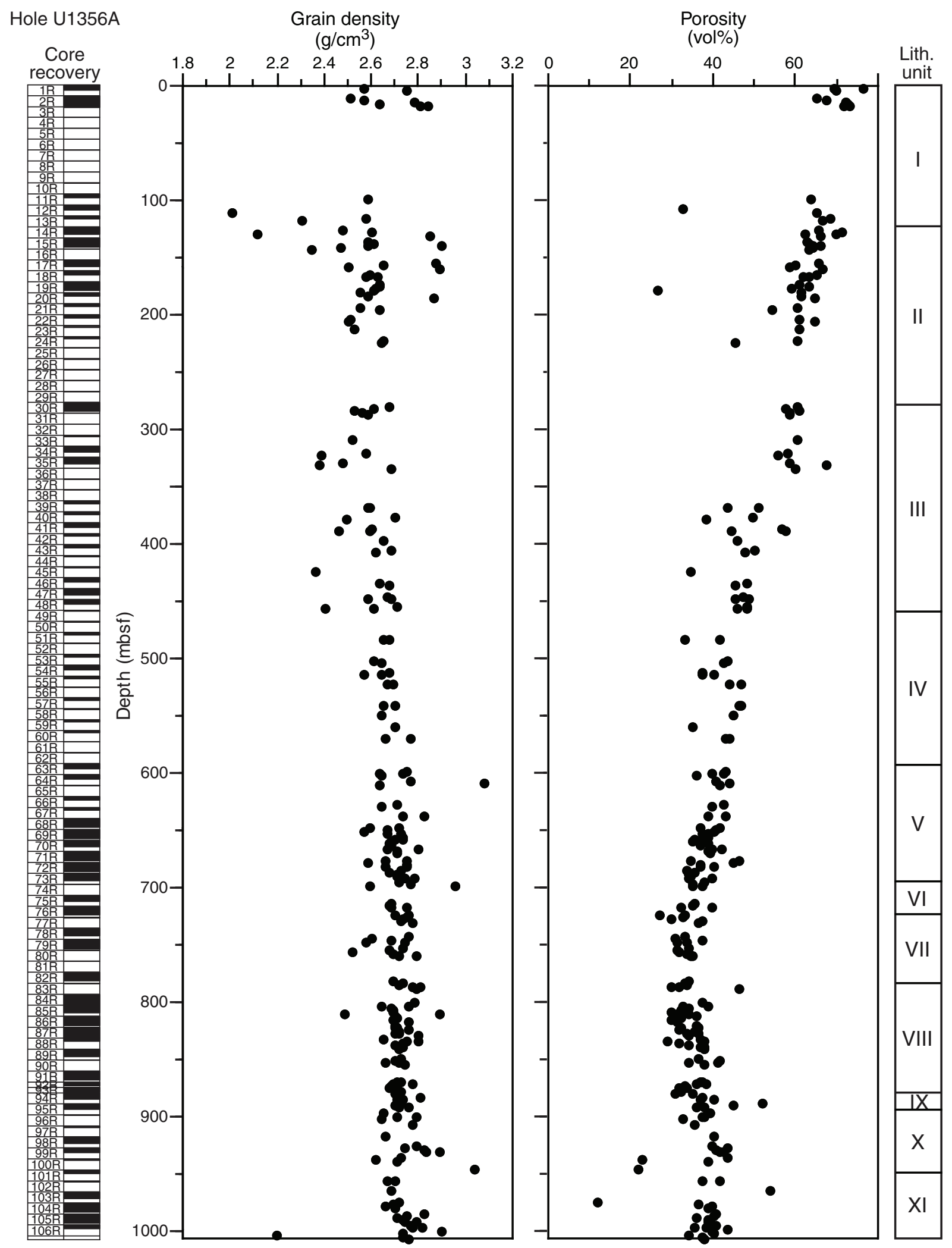


Figure F34. Wet bulk density and dry density from discrete measurements, Hole U1356A.

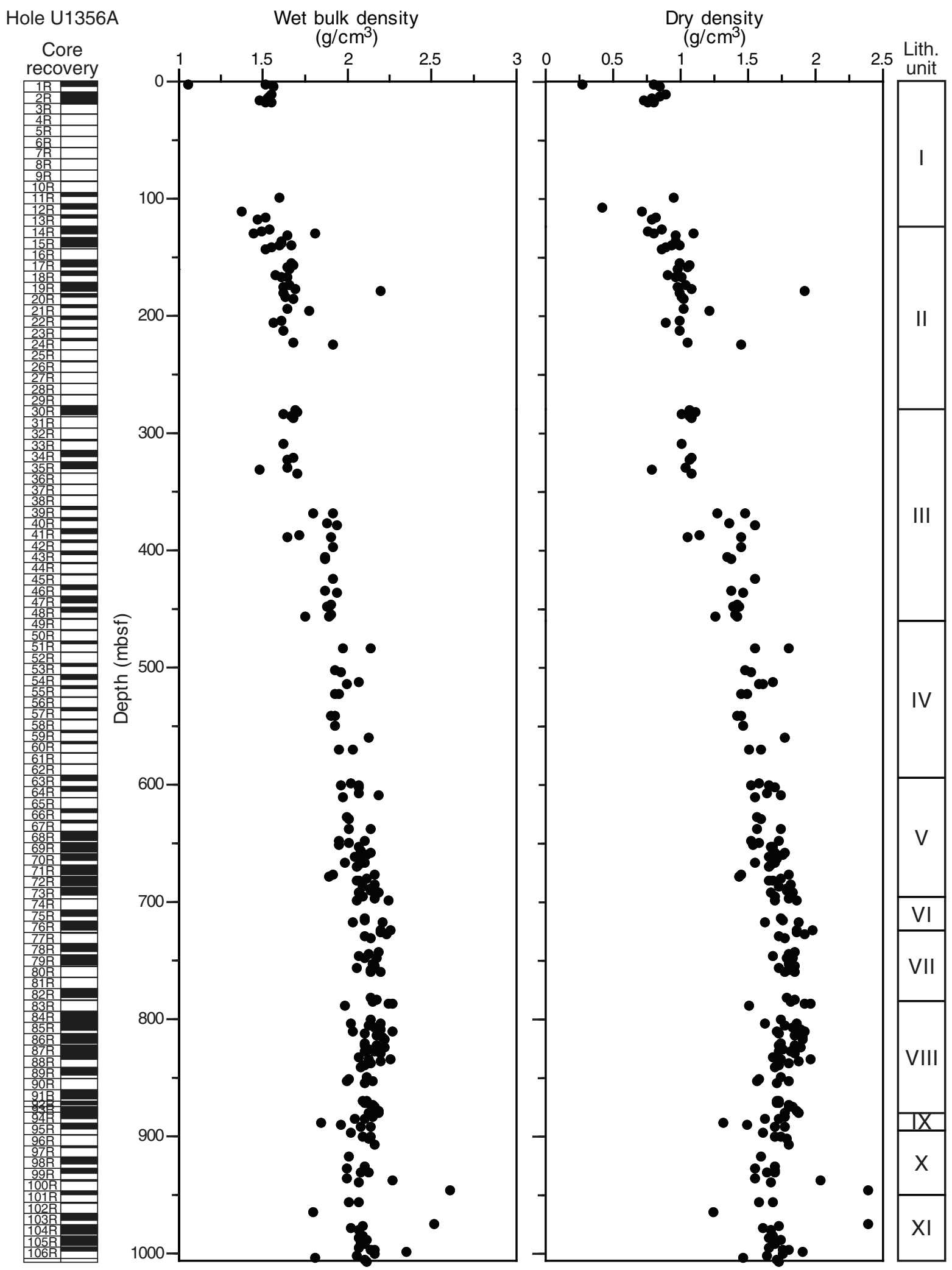


Figure F35. Moisture content and void ratio from discrete measurements, Hole U1356A.

Hole U1356A

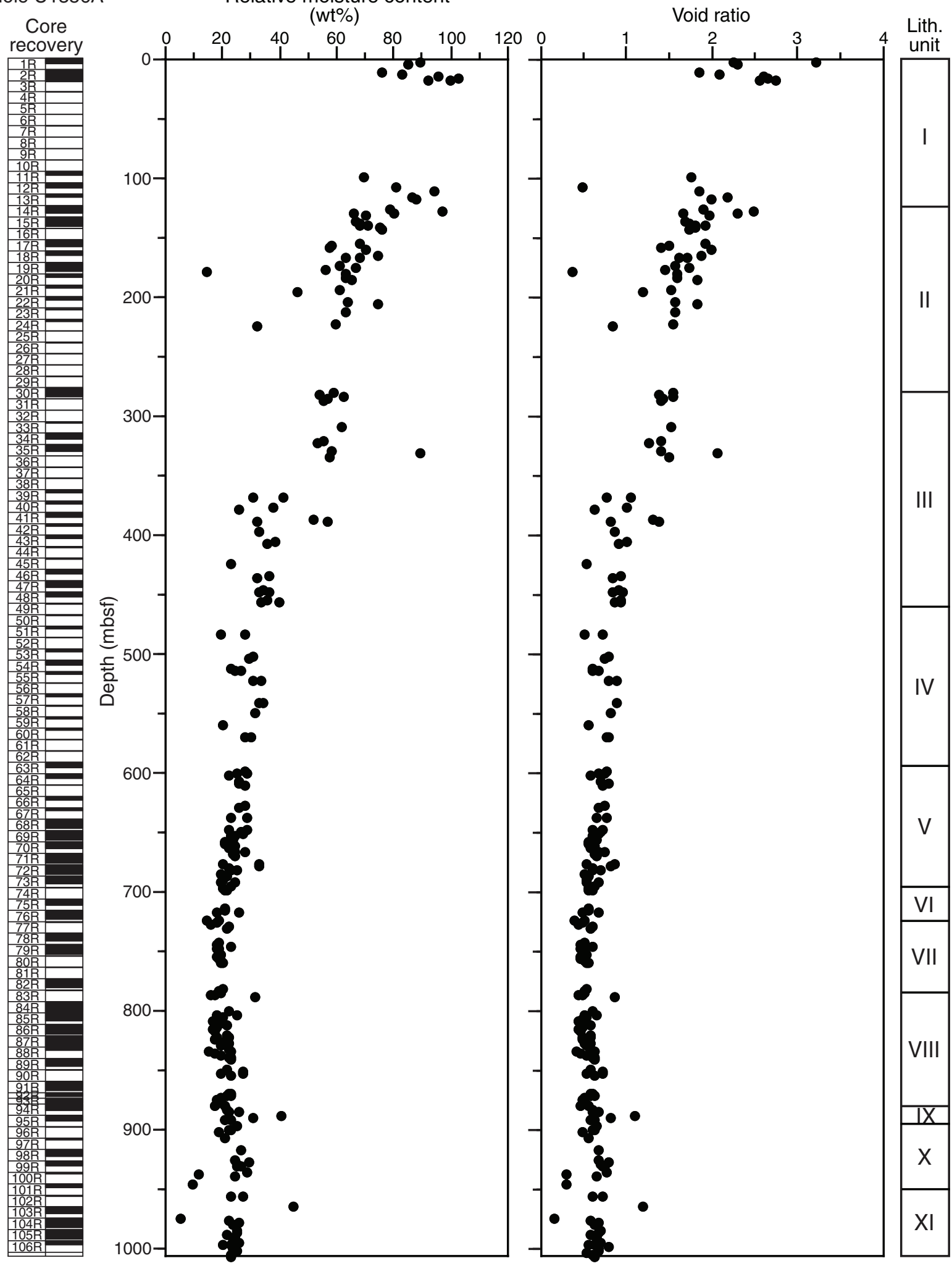


Figure F36. Thermal conductivity data, Hole U1356A.

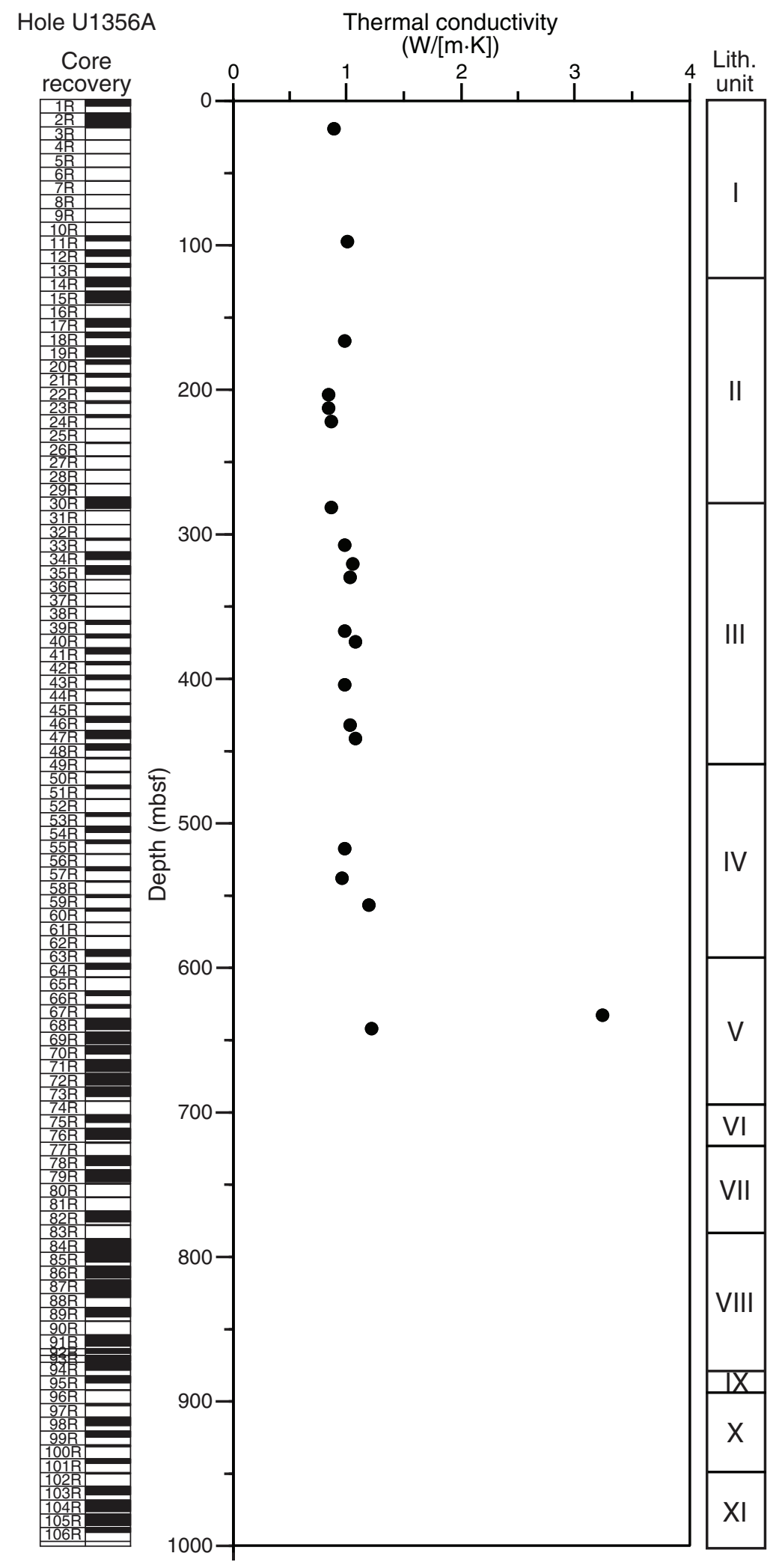


Table T1. Magnetostratigraphic tie points, Site U1356. (See table notes.)

\begin{tabular}{|c|c|c|c|c|c|}
\hline \multirow{2}{*}{$\begin{array}{l}\text { Chron } \\
\text { boundary }\end{array}$} & \multicolumn{2}{|c|}{ Core, section, interval $(\mathrm{cm})$} & \multicolumn{2}{|c|}{ Depth (mbsf) } & \multirow{2}{*}{$\begin{array}{l}\text { Age } \\
(\mathrm{Ma})\end{array}$} \\
\hline & Top & Bottom & Top & Bottom & \\
\hline & 318-U1356A- & 318-U1356A- & & & \\
\hline C5AA (y) & $14 \mathrm{R}-5,80$ & $15 \mathrm{R}-1,10$ & 130.40 & 133.90 & 13.015 \\
\hline C5ACn (o) & $22 \mathrm{R}-2,75$ & $22 \mathrm{R}-2,90$ & 203.15 & 203.30 & 14.095 \\
\hline CC5B.2n (y) & $30 \mathrm{R}-2,50$ & $30 \mathrm{R}-2,75$ & 279.50 & 279.75 & 15.032 \\
\hline C5C.1n (o) & $39 \mathrm{R}-1,35$ & $39 \mathrm{R}-1,65$ & 363.95 & 364.25 & 16.268 \\
\hline C5Cn.3n (o) & $42 \mathrm{R}-2,59$ & $43 \mathrm{R}-1,25$ & 394.21 & 402.25 & 16.721 \\
\hline C5Dn (y) & $44 \mathrm{R}-1,60$ & $45 \mathrm{R}-1,15$ & 412.20 & 421.35 & 17.235 \\
\hline C5Dn (o) & $46 \mathrm{R}-2,60$ & $46 \mathrm{R}-2,65$ & 432.84 & 432.89 & 17.533 \\
\hline C7An (o) & $68 \mathrm{R}-2,75$ & $68 \mathrm{R}-2,80$ & 643.65 & 643.70 & 25.091 \\
\hline C8n.1n (y) & $69 \mathrm{R}-2,15$ & $69 \mathrm{R}-2,25$ & 652.50 & 652.60 & 25.295 \\
\hline C $8 n .2 n(0)$ & $71 \mathrm{R}-6,15$ & $72 \mathrm{R}-1,10$ & 678.06 & 679.90 & 26.154 \\
\hline C9n (o) & $76 \mathrm{R}-6,35$ & $76 \mathrm{R}-6,40$ & 725.06 & 725.11 & 27.826 \\
\hline C11n.1n (o) & $82 \mathrm{R}-6,35$ & $82 \mathrm{R}-6,40$ & 782.65 & 782.70 & 29.740 \\
\hline $\mathrm{C} 12 \mathrm{n}(\mathrm{y})$ & $86 \mathrm{R}-2,115$ & $86 \mathrm{R}-7,10$ & 816.93 & 821.88 & 30.627 \\
\hline C23n.1n (y) & $98 \mathrm{R}-3,120$ & $98 \mathrm{R}-3,125$ & 923.44 & 923.49 & 50.730 \\
\hline C23n.1n (o) & $99 \mathrm{R}-1,35$ & $99 \mathrm{R}-1,80$ & 929.65 & 929.62 & 50.932 \\
\hline$C 23 n \cdot 2 n(y)$ & $100 \mathrm{R}-1,100$ & $101 \mathrm{R}-1,15$ & 940.10 & 948.95 & 51.057 \\
\hline C23n.2n (o) & $101 \mathrm{R}-1,100$ & $101 \mathrm{R}-2,90$ & 949.80 & 951.20 & 51.901 \\
\hline C24n.1n (y) & $102 \mathrm{R}-1,60$ & $103 \mathrm{R}-1,65$ & 959.00 & 968.65 & 52.648 \\
\hline C24n.1n (o) & 104R-1, 95 & $104 \mathrm{R}-1,100$ & 978.55 & 978.60 & 53.004 \\
\hline C24n.3n (y) & $104 \mathrm{R}-6,65$ & $105 \mathrm{R}-1,10$ & 985.36 & 987.30 & 53.286 \\
\hline C24n.3n (o) & 106R-1, 95 & $106 \mathrm{R}-1,100$ & 997.75 & 997.80 & 53.808 \\
\hline
\end{tabular}

Notes: $y=$ young, $\mathrm{o}=$ old. Correlations shown in Figure F21. Ages from Gradstein et al. (2004) timescale. 
Table T2. Coring summary, Site U1356. (See table notes.) (Continued on next page.)

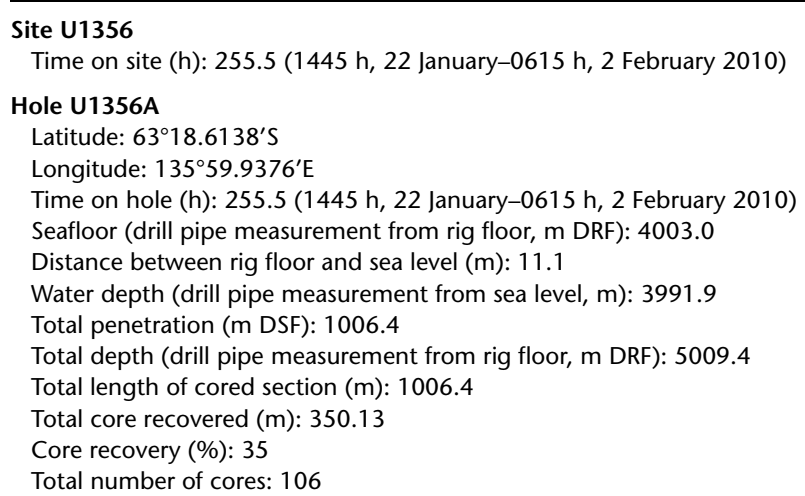

\begin{tabular}{|c|c|c|c|c|c|c|c|c|c|}
\hline \multirow[b]{2}{*}{ Core } & \multirow[b]{2}{*}{$\begin{array}{c}\text { Date } \\
(2010)\end{array}$} & \multirow[b]{2}{*}{$\begin{array}{l}\text { Local time } \\
\text { (h) }\end{array}$} & \multicolumn{2}{|c|}{ Depth DSF-A (m) } & \multirow[b]{2}{*}{$\begin{array}{l}\text { Interval } \\
\text { advanced } \\
(\mathrm{m})\end{array}$} & \multicolumn{2}{|c|}{ Depth CSF-A (m) } & \multirow[b]{2}{*}{$\begin{array}{l}\text { Length of core } \\
\text { recovered } \\
\text { (m) }\end{array}$} & \multirow[b]{2}{*}{$\begin{array}{c}\text { Recovery } \\
(\%)\end{array}$} \\
\hline & & & $\begin{array}{l}\text { Top of } \\
\text { cored } \\
\text { interval }\end{array}$ & $\begin{array}{l}\text { Bottom of } \\
\text { cored } \\
\text { interval }\end{array}$ & & $\begin{array}{l}\text { Top of } \\
\text { cored } \\
\text { interval }\end{array}$ & $\begin{array}{l}\text { Bottom of } \\
\text { cored } \\
\text { interval }\end{array}$ & & \\
\hline
\end{tabular}

\begin{tabular}{|c|c|c|c|c|c|c|c|c|c|}
\hline \multicolumn{10}{|c|}{ 318-U1356A- } \\
\hline $1 \mathrm{R}$ & $23 \mathrm{Jan}$ & 0205 & 0.0 & 9.5 & 9.5 & 0.0 & 4.6 & 4.60 & 48 \\
\hline $2 \mathrm{R}$ & $23 \mathrm{Jan}$ & 0355 & 9.5 & 19.2 & 9.7 & 9.5 & 19.1 & 9.60 & 99 \\
\hline $3 \mathrm{R}$ & $23 \mathrm{Jan}$ & 0535 & 19.2 & 28.2 & 9.0 & 19.2 & 19.8 & 0.60 & 7 \\
\hline $4 \mathrm{R}$ & $23 \mathrm{Jan}$ & 0720 & 28.2 & 37.8 & 9.6 & 28.2 & 28.4 & 0.18 & 2 \\
\hline $5 \mathrm{R}$ & $23 \mathrm{Jan}$ & 0855 & 37.8 & 47.3 & 9.5 & 37.8 & 37.9 & 0.08 & 1 \\
\hline $6 \mathrm{R}$ & $23 \mathrm{Jan}$ & 1025 & 47.3 & 56.9 & 9.6 & 47.3 & 47.4 & 0.09 & 1 \\
\hline $7 \mathrm{R}$ & $23 \operatorname{Jan}$ & 1200 & 56.9 & 66.5 & 9.6 & 56.9 & 57.0 & 0.14 & 1 \\
\hline $8 \mathrm{R}$ & $23 \operatorname{Jan}$ & 1300 & 66.5 & 76.1 & 9.6 & 66.5 & 66.6 & 0.07 & 1 \\
\hline $9 R$ & $23 \mathrm{Jan}$ & 1400 & 76.1 & 85.7 & 9.6 & 76.1 & 76.3 & 0.16 & 2 \\
\hline $10 \mathrm{R}$ & $23 \mathrm{Jan}$ & 1455 & 85.7 & 95.4 & 9.7 & 85.7 & 85.9 & 0.19 & 2 \\
\hline $11 \mathrm{R}$ & $23 \mathrm{Jan}$ & 1605 & 95.4 & 104.9 & 9.5 & 95.4 & 98.7 & 3.26 & 34 \\
\hline $12 \mathrm{R}$ & $23 \mathrm{Jan}$ & 1715 & 104.9 & 114.5 & 9.6 & 104.9 & 109.3 & 4.43 & 46 \\
\hline $13 \mathrm{R}$ & $23 \mathrm{Jan}$ & 1830 & 114.5 & 124.1 & 9.6 & 114.5 & 117.3 & 2.75 & 29 \\
\hline $14 \mathrm{R}$ & $23 \mathrm{Jan}$ & 1930 & 124.1 & 133.8 & 9.7 & 124.1 & 130.7 & 6.60 & 68 \\
\hline $15 R$ & $23 \operatorname{Jan}$ & 2025 & 133.8 & 143.4 & 9.6 & 133.8 & 141.8 & 7.95 & 83 \\
\hline $16 \mathrm{R}$ & $23 \mathrm{Jan}$ & 2130 & 143.4 & 153.0 & 9.6 & 143.4 & 143.5 & 0.14 & 1 \\
\hline $17 R$ & $23 \mathrm{Jan}$ & 2235 & 153.0 & 162.5 & 9.5 & 153.0 & 158.8 & 5.84 & 61 \\
\hline $18 \mathrm{R}$ & $23 \mathrm{Jan}$ & 2345 & 162.5 & 172.1 & 9.6 & 162.5 & 166.3 & 3.79 & 39 \\
\hline $19 \mathrm{R}$ & $24 \mathrm{Jan}$ & 0105 & 172.1 & 181.7 & 9.6 & 172.1 & 179.7 & 7.64 & 80 \\
\hline $20 \mathrm{R}$ & $24 \mathrm{Jan}$ & 0240 & 181.7 & 191.3 & 9.6 & 181.7 & 184.7 & 2.96 & 31 \\
\hline $21 R$ & $24 \mathrm{Jan}$ & 0410 & 191.3 & 200.9 & 9.6 & 191.3 & 193.9 & 2.55 & 27 \\
\hline $22 \mathrm{R}$ & $24 \mathrm{Jan}$ & 0540 & 200.9 & 210.5 & 9.6 & 200.9 & 204.0 & 3.05 & 32 \\
\hline $23 R$ & 24 Jan & 0705 & 210.5 & 220.1 & 9.6 & 210.5 & 212.1 & 1.56 & 16 \\
\hline $24 \mathrm{R}$ & $24 \mathrm{Jan}$ & 0840 & 220.1 & 229.7 & 9.6 & 220.1 & 222.1 & 1.96 & 20 \\
\hline $25 \mathrm{R}$ & $24 \mathrm{Jan}$ & 1000 & 229.7 & 239.3 & 9.6 & 229.7 & 230.0 & 0.25 & 3 \\
\hline $26 \mathrm{R}$ & $24 \mathrm{Jan}$ & 1140 & 239.3 & 248.9 & 9.6 & 239.3 & 240.0 & 0.70 & 7 \\
\hline $27 R$ & $24 \mathrm{Jan}$ & 1245 & 248.9 & 258.4 & 9.5 & 248.9 & 249.1 & 0.23 & 2 \\
\hline $28 \mathrm{R}$ & 24 Jan & 1415 & 258.4 & 268.0 & 9.6 & 258.4 & 258.6 & 0.19 & 2 \\
\hline $29 \mathrm{R}$ & $24 \mathrm{Jan}$ & 1525 & 268.0 & 277.5 & 9.5 & 268.0 & 268.2 & 0.20 & 2 \\
\hline $30 \mathrm{R}$ & 24 Jan & 1635 & 277.5 & 287.0 & 9.5 & 277.5 & 285.3 & 7.78 & 82 \\
\hline $31 R$ & $24 \mathrm{Jan}$ & 1750 & 287.0 & 296.7 & 9.7 & 287.0 & 287.1 & 0.08 & 1 \\
\hline $32 \mathrm{R}$ & $24 \mathrm{Jan}$ & 1855 & 296.7 & 306.4 & 9.7 & 296.7 & 296.7 & 0.00 & 0 \\
\hline $33 R$ & $24 \mathrm{Jan}$ & 2020 & 306.4 & 315.9 & 9.5 & 306.4 & 307.7 & 1.27 & 13 \\
\hline $34 \mathrm{R}$ & $24 \mathrm{Jan}$ & 2135 & 315.9 & 325.5 & 9.6 & 315.9 & 321.2 & 5.26 & 55 \\
\hline $35 R$ & $24 \mathrm{Jan}$ & 2255 & 325.5 & 335.1 & 9.6 & 325.5 & 331.5 & 5.99 & 62 \\
\hline $36 \mathrm{R}$ & $25 \mathrm{Jan}$ & 0010 & 335.1 & 344.7 & 9.6 & 335.1 & 335.1 & 0.03 & 0 \\
\hline $37 R$ & $25 \mathrm{Jan}$ & 0145 & 344.7 & 354.0 & 9.3 & 344.7 & 344.8 & 0.13 & 1 \\
\hline $38 \mathrm{R}$ & $25 \mathrm{Jan}$ & 0305 & 354.0 & 363.6 & 9.6 & 354.0 & 354.1 & 0.06 & 1 \\
\hline $39 R$ & $25 \mathrm{Jan}$ & 0450 & 363.6 & 373.2 & 9.6 & 363.6 & 366.3 & 2.65 & 28 \\
\hline $40 \mathrm{R}$ & $25 \mathrm{Jan}$ & 0640 & 373.2 & 382.8 & 9.6 & 373.2 & 375.8 & 2.62 & 27 \\
\hline $41 R$ & $25 \mathrm{Jan}$ & 0855 & 382.8 & 392.4 & 9.6 & 382.8 & 387.0 & 4.20 & 44 \\
\hline $42 R$ & $25 \mathrm{Jan}$ & 1115 & 392.4 & 402.0 & 9.6 & 392.4 & 394.5 & 2.06 & 21 \\
\hline $43 R$ & $25 \mathrm{Jan}$ & 1340 & 402.0 & 411.6 & 9.6 & 402.0 & 404.9 & 2.89 & 30 \\
\hline $44 R$ & $25 \mathrm{Jan}$ & 1535 & 411.6 & 421.2 & 9.6 & 411.6 & 412.6 & 0.98 & 10 \\
\hline $45 \mathrm{R}$ & $25 \mathrm{Jan}$ & 1750 & 421.2 & 430.8 & 9.6 & 421.2 & 422.3 & 1.12 & 12 \\
\hline $46 \mathrm{R}$ & $25 \mathrm{Jan}$ & 2000 & 430.8 & 440.4 & 9.6 & 430.8 & 434.7 & 3.91 & 41 \\
\hline $47 R$ & $25 \mathrm{Jan}$ & 2240 & 440.4 & 449.9 & 9.5 & 440.4 & 446.0 & 5.64 & 59 \\
\hline $48 \mathrm{R}$ & $26 \mathrm{Jan}$ & 0200 & 449.9 & 459.4 & 9.5 & 449.9 & 454.1 & 4.18 & 44 \\
\hline $49 \mathrm{R}$ & $26 \mathrm{Jan}$ & 0455 & 459.4 & 469.0 & 9.6 & 459.4 & 460.1 & 0.70 & 7 \\
\hline
\end{tabular}


Table T2 (continued).

\begin{tabular}{|c|c|c|c|c|c|c|c|c|c|}
\hline \multirow[b]{2}{*}{ Core } & \multirow[b]{2}{*}{$\begin{array}{l}\text { Date } \\
\text { (2010) }\end{array}$} & \multirow[b]{2}{*}{$\begin{array}{l}\text { Local time } \\
\text { (h) }\end{array}$} & \multicolumn{2}{|c|}{ Depth DSF-A (m) } & \multirow[b]{2}{*}{$\begin{array}{l}\text { Interval } \\
\text { advanced } \\
\text { (m) }\end{array}$} & \multicolumn{2}{|c|}{ Depth CSF-A (m) } & \multirow[b]{2}{*}{$\begin{array}{l}\text { Length of core } \\
\text { recovered } \\
\text { (m) }\end{array}$} & \multirow[b]{2}{*}{$\begin{array}{c}\text { Recovery } \\
\text { (\%) }\end{array}$} \\
\hline & & & $\begin{array}{l}\text { Top of } \\
\text { cored } \\
\text { interval }\end{array}$ & $\begin{array}{l}\text { Bottom of } \\
\text { cored } \\
\text { interval }\end{array}$ & & $\begin{array}{l}\text { Top of } \\
\text { cored } \\
\text { interval }\end{array}$ & $\begin{array}{l}\text { Bottom of } \\
\text { cored } \\
\text { interval }\end{array}$ & & \\
\hline $50 \mathrm{R}$ & $26 \mathrm{Jan}$ & 0725 & 469.0 & 478.6 & 9.6 & 469.0 & 469.9 & 0.92 & 10 \\
\hline $51 \mathrm{R}$ & $26 \mathrm{Jan}$ & 0925 & 478.6 & 488.2 & 9.6 & 478.6 & 481.1 & 2.50 & 26 \\
\hline $52 \mathrm{R}$ & $26 \mathrm{Jan}$ & 1205 & 488.2 & 497.8 & 9.6 & 488.2 & 488.4 & 0.18 & 2 \\
\hline $53 \mathrm{R}$ & $26 \mathrm{Jan}$ & 1525 & 497.8 & 507.4 & 9.6 & 497.8 & 500.5 & 2.66 & 28 \\
\hline $54 \mathrm{R}$ & $26 \mathrm{Jan}$ & 1815 & 507.4 & 517.0 & 9.6 & 507.4 & 511.6 & 4.16 & 43 \\
\hline $55 \mathrm{R}$ & $26 \mathrm{Jan}$ & 2030 & 517.0 & 526.5 & 9.5 & 517.0 & 519.2 & 2.24 & 24 \\
\hline $56 \mathrm{R}$ & 26 Jan & 2205 & 526.5 & 535.8 & 9.3 & 526.5 & 526.9 & 0.37 & 4 \\
\hline $57 R$ & 27 Jan & 0010 & 535.8 & 545.4 & 9.6 & 535.8 & 538.2 & 2.38 & 25 \\
\hline $58 \mathrm{R}$ & $27 \mathrm{Jan}$ & 0245 & 545.4 & 555.0 & 9.6 & 545.4 & 546.3 & 0.89 & 9 \\
\hline $59 \mathrm{R}$ & $27 \mathrm{Jan}$ & 0510 & 555.0 & 564.6 & 9.6 & 555.0 & 556.9 & 1.87 & 19 \\
\hline $60 \mathrm{R}$ & $27 \mathrm{Jan}$ & 0725 & 564.6 & 574.2 & 9.6 & 564.6 & 566.4 & 1.82 & 19 \\
\hline $61 \mathrm{R}$ & 27 Jan & 0935 & 574.2 & 583.8 & 9.6 & 574.2 & 574.4 & 0.19 & 2 \\
\hline $62 \mathrm{R}$ & $27 \mathrm{Jan}$ & 1155 & 583.8 & 593.4 & 9.6 & 583.8 & 584.2 & 0.37 & 4 \\
\hline $63 \mathrm{R}$ & $27 \mathrm{Jan}$ & 1355 & 593.4 & 603.0 & 9.6 & 593.4 & 598.1 & 4.70 & 49 \\
\hline $64 \mathrm{R}$ & $27 \mathrm{Jan}$ & 1605 & 603.0 & 612.6 & 9.6 & 603.0 & 607.1 & 4.11 & 43 \\
\hline $65 \mathrm{R}$ & $27 \mathrm{Jan}$ & 1835 & 612.6 & 622.3 & 9.7 & 612.6 & 612.7 & 0.10 & 1 \\
\hline $66 \mathrm{R}$ & 27 Jan & 2255 & 622.3 & 631.9 & 9.6 & 622.3 & 625.4 & 3.05 & 32 \\
\hline $67 \mathrm{R}$ & $28 \mathrm{Jan}$ & 0150 & 631.9 & 641.4 & 9.5 & 631.9 & 634.3 & 2.38 & 25 \\
\hline $68 \mathrm{R}$ & 28 Jan & 0425 & 641.4 & 651.0 & 9.6 & 641.4 & 649.2 & 7.79 & 81 \\
\hline $69 \mathrm{R}$ & $28 \mathrm{Jan}$ & 0655 & 651.0 & 660.6 & 9.6 & 651.0 & 659.1 & 8.06 & 84 \\
\hline $70 \mathrm{R}$ & $28 \mathrm{Jan}$ & 0935 & 660.6 & 670.2 & 9.6 & 660.6 & 666.1 & 5.48 & 57 \\
\hline $71 \mathrm{R}$ & $28 \mathrm{Jan}$ & 1235 & 670.2 & 679.8 & 9.6 & 670.2 & 678.4 & 8.15 & 85 \\
\hline $72 \mathrm{R}$ & $28 \mathrm{Jan}$ & 1530 & 679.8 & 689.4 & 9.6 & 679.8 & 687.9 & 8.05 & 84 \\
\hline $73 \mathrm{R}$ & $28 \mathrm{Jan}$ & 1800 & 689.4 & 699.0 & 9.6 & 689.4 & 695.8 & 6.41 & 67 \\
\hline $74 \mathrm{R}$ & $28 \mathrm{Jan}$ & 2030 & 699.0 & 708.6 & 9.6 & 699.0 & 699.3 & 0.25 & 3 \\
\hline $75 \mathrm{R}$ & $28 \mathrm{Jan}$ & 2315 & 708.6 & 718.2 & 9.6 & 708.6 & 714.0 & 5.36 & 56 \\
\hline $76 \mathrm{R}$ & 29 Jan & 0215 & 718.2 & 727.8 & 9.6 & 718.2 & 725.7 & 7.45 & 78 \\
\hline $77 R$ & 29 Jan & 0555 & 727.8 & 737.4 & 9.6 & 727.8 & 728.4 & 0.56 & 6 \\
\hline $78 \mathrm{R}$ & 29 Jan & 0845 & 737.4 & 747.0 & 9.6 & 737.4 & 744.1 & 6.73 & 70 \\
\hline $79 \mathrm{R}$ & $29 \mathrm{Jan}$ & 1105 & 747.0 & 756.6 & 9.6 & 747.0 & 755.5 & 8.46 & 88 \\
\hline $80 \mathrm{R}$ & 29 Jan & 1405 & 756.6 & 766.2 & 9.6 & 756.6 & 756.8 & 0.23 & 2 \\
\hline $81 \mathrm{R}$ & $29 \mathrm{Jan}$ & 1655 & 766.2 & 775.8 & 9.6 & 766.2 & 766.4 & 0.16 & 2 \\
\hline $82 \mathrm{R}$ & 29 Jan & 1945 & 775.8 & 785.5 & 9.7 & 775.8 & 783.4 & 7.62 & 79 \\
\hline $83 \mathrm{R}$ & 29 Jan & 2305 & 785.5 & 795.1 & 9.6 & 785.5 & 786.0 & 0.50 & 5 \\
\hline $84 \mathrm{R}$ & 29 Jan & 0220 & 795.1 & 804.7 & 9.6 & 795.1 & 804.4 & 9.33 & 97 \\
\hline $85 \mathrm{R}$ & $30 \mathrm{Jan}$ & 0510 & 804.7 & 814.3 & 9.6 & 804.7 & 811.3 & 6.64 & 69 \\
\hline $86 \mathrm{R}$ & $30 \mathrm{Jan}$ & 0800 & 814.3 & 823.9 & 9.6 & 814.3 & 822.5 & 8.24 & 86 \\
\hline $87 R$ & 30 Jan & 1040 & 823.9 & 833.5 & 9.6 & 823.9 & 833.2 & 9.30 & 97 \\
\hline $88 \mathrm{R}$ & 30 Jan & 1250 & 833.5 & 843.1 & 9.6 & 833.5 & 836.1 & 2.61 & 27 \\
\hline $89 \mathrm{R}$ & 30 Jan & 1610 & 843.1 & 852.7 & 9.6 & 843.1 & 849.7 & 6.58 & 69 \\
\hline $90 \mathrm{R}$ & 30 Jan & 1840 & 852.7 & 862.3 & 9.6 & 852.7 & 852.9 & 0.20 & 2 \\
\hline $91 \mathrm{R}$ & $30 \mathrm{Jan}$ & 2100 & 862.3 & 871.9 & 9.6 & 862.3 & 870.1 & 7.77 & 81 \\
\hline $92 \mathrm{R}$ & 30 Jan & 2310 & 871.9 & 876.6 & 4.7 & 871.9 & 875.1 & 3.22 & 69 \\
\hline $93 \mathrm{R}$ & $31 \mathrm{Jan}$ & 0105 & 876.6 & 881.4 & 4.8 & 876.6 & 880.7 & 4.14 & 86 \\
\hline $94 \mathrm{R}$ & 31 Jan & 0350 & 881.4 & 891.0 & 9.6 & 881.4 & 886.9 & 5.54 & 58 \\
\hline $95 \mathrm{R}$ & $31 \mathrm{Jan}$ & 0615 & 891.0 & 900.6 & 9.6 & 891.0 & 895.7 & 4.72 & 49 \\
\hline $96 \mathrm{R}$ & 31 Jan & 0820 & 900.6 & 910.2 & 9.6 & 900.6 & 901.0 & 0.40 & 4 \\
\hline $97 \mathrm{R}$ & 31 Jan & 1105 & 910.2 & 919.8 & 9.6 & 910.2 & 911.7 & 1.53 & 16 \\
\hline $98 \mathrm{R}$ & $31 \mathrm{Jan}$ & 1315 & 919.8 & 929.4 & 9.6 & 919.8 & 925.6 & 5.75 & 60 \\
\hline $99 \mathrm{R}$ & 31 Jan & 1525 & 929.4 & 939.1 & 9.7 & 929.4 & 933.5 & 4.12 & 42 \\
\hline $100 \mathrm{R}$ & 31 Jan & 1735 & 939.1 & 948.8 & 9.7 & 939.1 & 940.4 & 1.32 & 14 \\
\hline $101 R$ & 31 Jan & 1940 & 948.8 & 958.4 & 9.6 & 948.8 & 952.0 & 3.17 & 33 \\
\hline $102 \mathrm{R}$ & 31 Jan & 2145 & 958.4 & 968.0 & 9.6 & 958.4 & 959.2 & 0.80 & 8 \\
\hline $103 R$ & 31 Jan & 2345 & 968.0 & 977.6 & 9.6 & 968.0 & 973.9 & 5.85 & 61 \\
\hline $104 \mathrm{R}$ & 1 Feb & 0220 & 977.6 & 987.2 & 9.6 & 977.6 & 985.6 & 8.04 & 84 \\
\hline $105 R$ & 1 Feb & 0445 & 987.2 & 996.8 & 9.6 & 987.2 & 995.3 & 8.12 & 85 \\
\hline \multirow[t]{3}{*}{$106 \mathrm{R}$} & 1 Feb & 0735 & 996.8 & 1006.4 & 9.6 & 996.8 & 1000.1 & 3.28 & 34 \\
\hline & & & & red totals: & 1006.4 & & & 350.13 & 35 \\
\hline & & & \multicolumn{2}{|c|}{ Total interval cored: } & 1006.4 & & & & \\
\hline
\end{tabular}

Notes: DRF = drilling depth below rig floor. DSF-A = drilling depth below seafloor, determined by tagging seafloor, CSF-A = core depth below seafloor, overlap if long. Local time $=$ UTC $+11 \mathrm{~h}$. 
Table T3. Siliceous microfossil abundance and preservation, Hole U1356A. This table is available in an oversized format. 


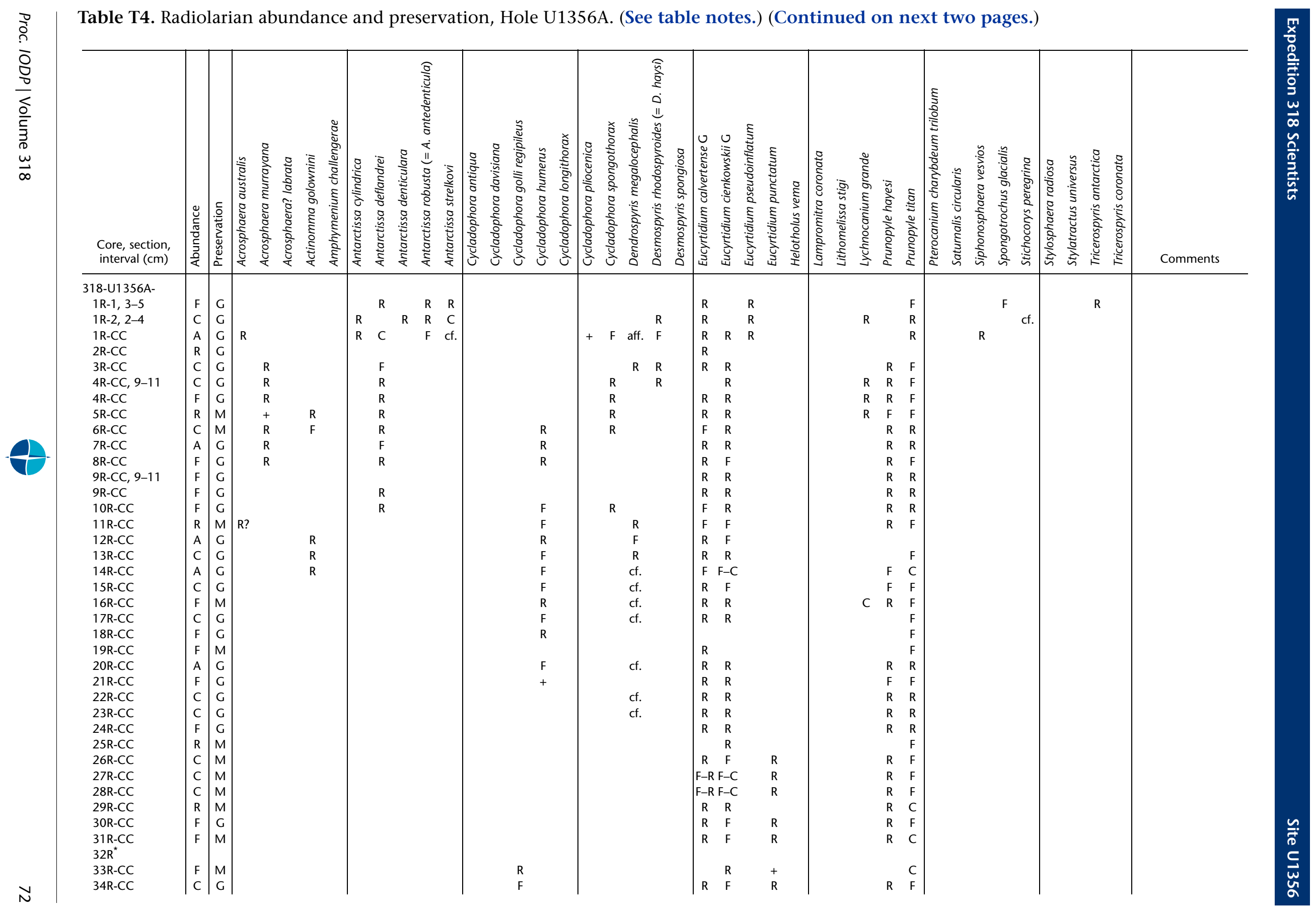




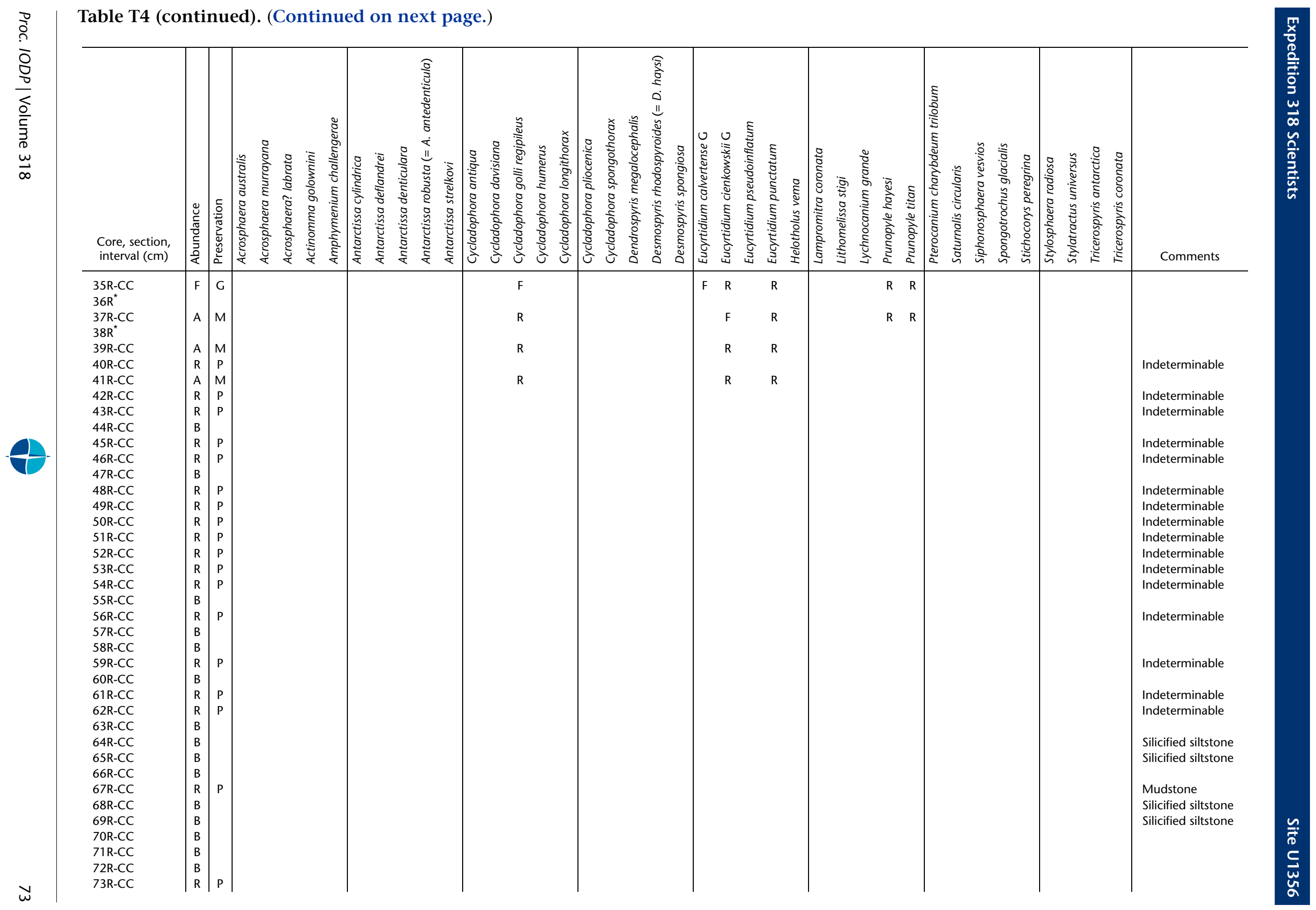




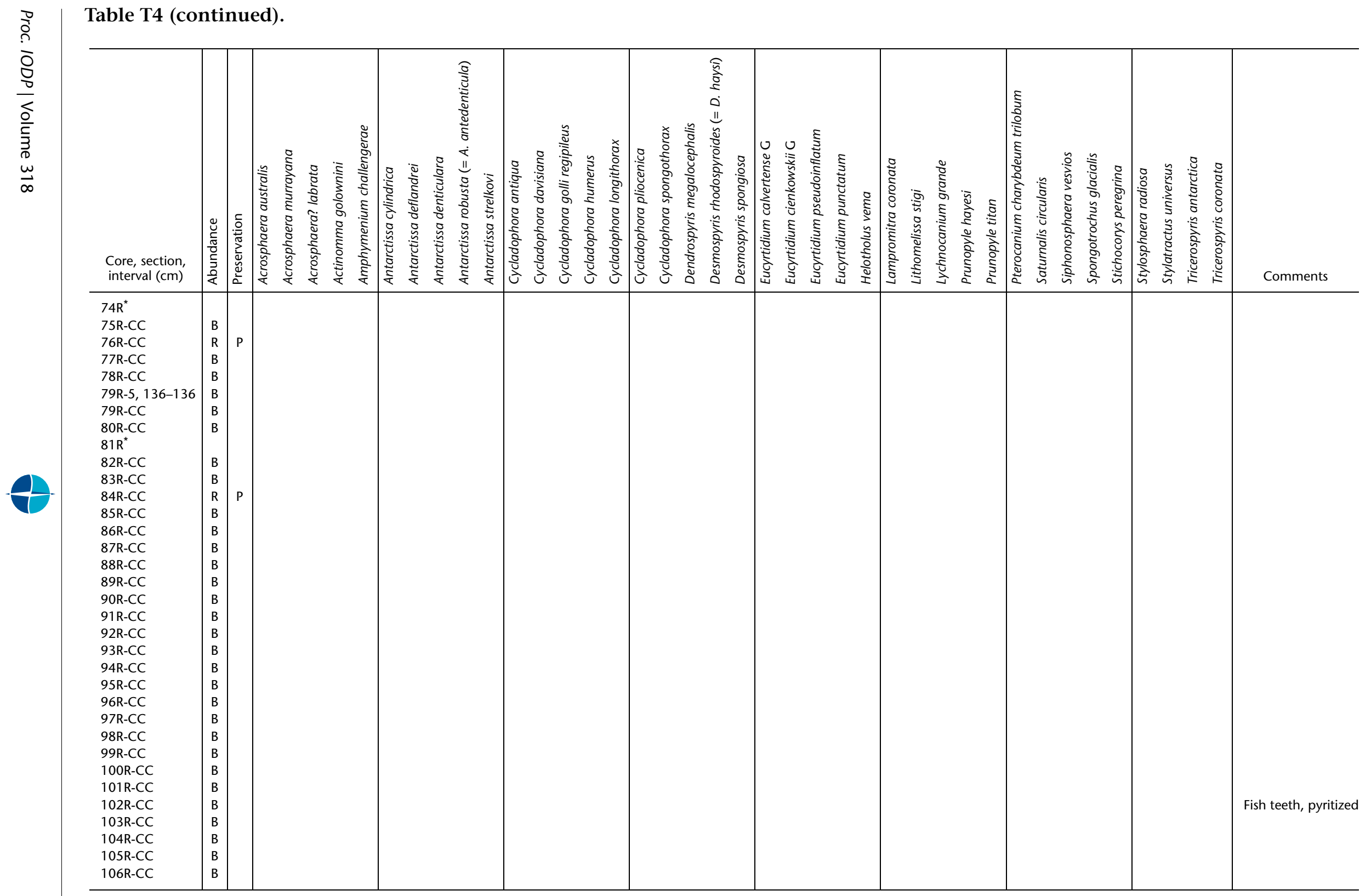

Notes: Abundance: $\mathrm{A}=$ abundant, $\mathrm{C}=$ common, $\mathrm{F}=$ few, $\mathrm{R}=$ rare, $\mathrm{B}=$ barren. Preservation: $\mathrm{G}=$ good, $\mathrm{M}=$ medium, $\mathrm{P}=$ poor. $+=$ present, ? $=$ uncertainty, cf. $=$ confer, aff. $=$ affinis. ${ }^{*}=$ no radiolarians present. See "Biostratigraphy" in the "Methods" chapter for abundance and preservation definitions. 


\begin{tabular}{|c|c|c|c|c|c|c|c|}
\hline \multirow{2}{*}{$\begin{array}{l}\text { Core, } \\
\text { section }\end{array}$} & \multicolumn{2}{|c|}{ Sample $(\mathrm{cm})$} & \multirow[b]{2}{*}{ Marker species or datum } & \multicolumn{2}{|c|}{ Nannoplankton zone } & \multirow[b]{2}{*}{ Chron/Subchron } & \multirow[b]{2}{*}{ Chronostratigraphic unit } \\
\hline & Upper & Lower & & Martini, 1971 & Okada and Bukry, 1980 & & \\
\hline \multicolumn{8}{|c|}{ 318-U1356A- } \\
\hline & $47 \mathrm{R}-3,126-127$ & $47 R-4,31-32$ & LO Reticulofenestra bisecta & NP25 & CP19b & $\mathrm{C} 6 \mathrm{Cn} \cdot 2 \mathrm{r}$ & latest Oligocene close to $\mathrm{O} / \mathrm{M}$ boundary \\
\hline & $47 \mathrm{R}-\mathrm{CC}$ & $48 \mathrm{R}-1,6-7$ & LO Chiasmolithus altus & NP25 & CP19b & CN8 & late Oligocene \\
\hline $55 \mathrm{R}-\mathrm{CC}$ & & & Reticulofenestra bisecta present & NP25-NP17 & CP19a-CP14b & $\mathrm{C} 6 \mathrm{Cn}$ (base) to $\mathrm{C} 8 \mathrm{n}$ & late Oligocene \\
\hline 60R-CC & & & Reticulofenestra bisecta present & NP25-NP17 & CP19a-CP14b & $\mathrm{C} 6 \mathrm{Cn}$ (base) to $\mathrm{C} 8 \mathrm{n}$ & late Oligocene \\
\hline $64 \mathrm{R}-\mathrm{CC}$ & & & Dissolved & NP 25? & CP19a? & $?$ & $?$ \\
\hline $65 \mathrm{R}-\mathrm{CC}$ & & & Dissolved & NP 25? & CP19a? & $?$ & $?$ \\
\hline $67 \mathrm{R}-\mathrm{CC}$ & & & Reticulofenestra bisecta (reworked) & NP25-NP17 & CP19a-CP14b & $?$ & ?late Oligocene \\
\hline 73R-CC & & & $\begin{array}{l}\text { Reticulofenestra bisecta, Cyclicargolithus } \\
\text { floridanus, Chiasmolithus altus present }\end{array}$ & NP25-NP22/23 & CP19a-CP16c/17 & Older than or $=\mathrm{C} 8 \mathrm{n}$ & late Oligocene \\
\hline \multirow[t]{2}{*}{ 74R-CC } & & & $\begin{array}{l}\text { Reticulofenestra bisecta, Cyclicargolithus } \\
\text { floridanus, Chiasmolithus altus present }\end{array}$ & NP25-NP22/23 & CP19a-CP16c/17 & Older than or $=\mathrm{C} 8 \mathrm{n}$ & late Oligocene \\
\hline & 78R-CC & $79 \mathrm{R}-1,12-13$ & LO Cyclicargolithus abisectus & Mid NP23 & CP18 & Top $\mathrm{C} 11.2 \mathrm{n}$ to base $\mathrm{C} 12 \mathrm{r}$ & early Oligocene \\
\hline \multirow[t]{2}{*}{$85 \mathrm{R}-\mathrm{CC}$} & & & Cyclicargolithus abisectus? & Mid NP23 & CP18 & Top $\mathrm{C} 11.2 \mathrm{n}$ to base $\mathrm{C} 12 \mathrm{r}$ & early Oligocene \\
\hline & 93R-CC & $94 \mathrm{R}-4,29-30$ & LO Reticulofenestra umbilicus & NP22/23 & CP16/17 & Late $\mathrm{C} 12 \mathrm{r}$ & early Oligocene \\
\hline 94R-CC & & & $\begin{array}{l}\text { Isthmolithus recurvus, Reticulofenestra umbilicus, } \\
\text { Chiasmolithus oamaruensis present }\end{array}$ & NP22-NP18 & CP16c-CP15a & Early $\mathrm{C} 12 \mathrm{r}$ to $\mathrm{C} 16 \mathrm{n} .2 \mathrm{n}$ & late Eocene-early Oligocene \\
\hline
\end{tabular}

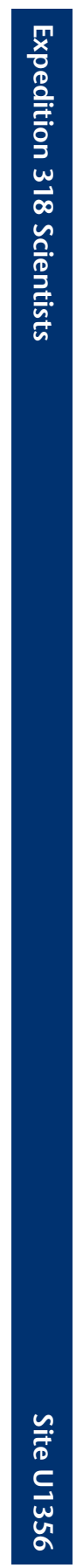

Notes: $\mathrm{LO}=$ last occurrence. $\mathrm{O} / \mathrm{M}=$ Oligocene/Miocene. 
Table T6. Calcareous nannofossil abundance and preservation, Hole U1356A. (See table notes.) (Continued on next two pages.)

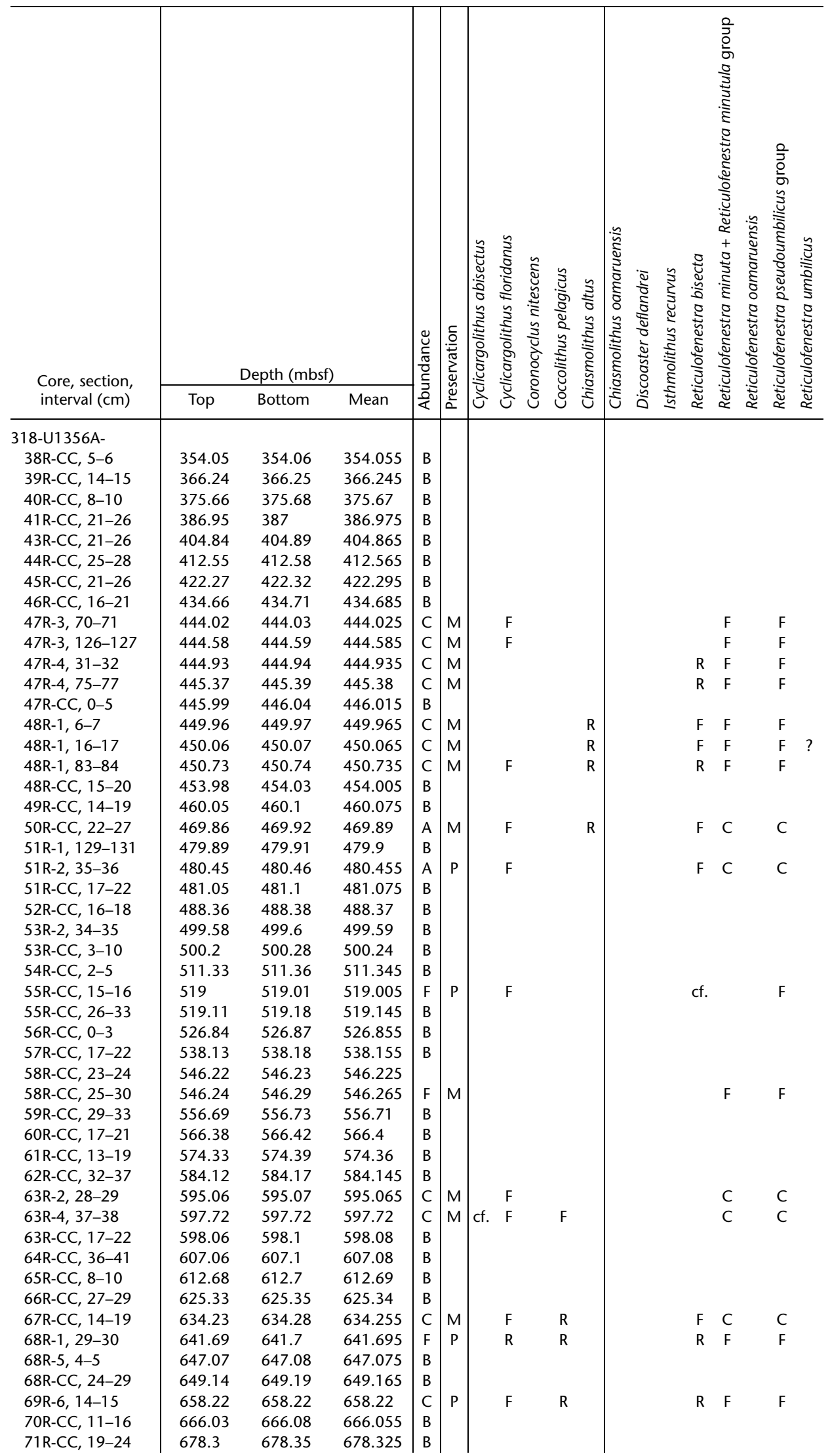


Table T6 (continued). (Continued on next page.)

\begin{tabular}{|c|c|c|c|c|c|c|c|c|c|c|c|c|c|c|c|}
\hline \multirow{2}{*}{$\begin{array}{l}\text { Core, section, } \\
\text { interval }(\mathrm{cm})\end{array}$} & \multicolumn{3}{|c|}{ Depth (mbsf) } & \multirow{2}{*}{ 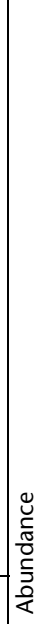 } & \multirow{2}{*}{ 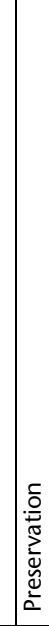 } & \multirow[t]{2}{*}{ 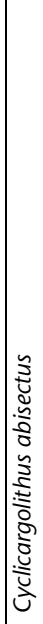 } & \multirow[t]{2}{*}{ 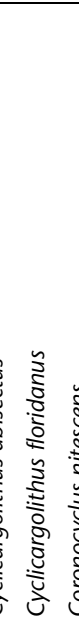 } & \multirow[t]{2}{*}{ 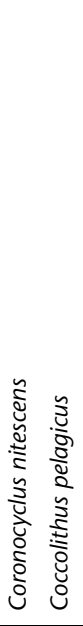 } & \multirow[t]{2}{*}{ 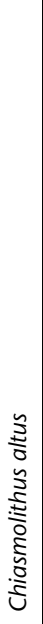 } & \multirow[t]{2}{*}{ 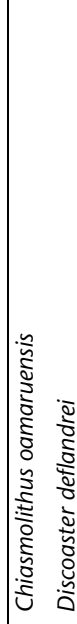 } & \multirow[t]{2}{*}{ 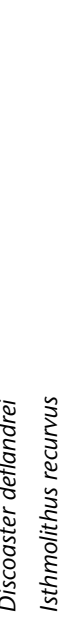 } & \multirow[t]{2}{*}{ 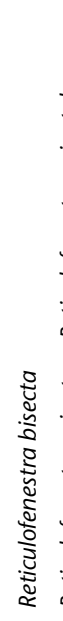 } & \multirow[t]{2}{*}{ 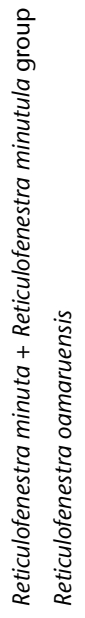 } & \multirow{2}{*}{\multicolumn{2}{|c|}{ 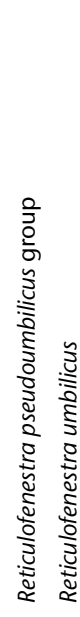 }} \\
\hline & Top & Bottom & Mean & & & & & & & & & & & & \\
\hline $72 \mathrm{R}-1,20-20$ & 680 & 680 & 680 & B & & & & & & & & & & & \\
\hline 72R-4, 119-119 & 685.02 & 685.02 & 685.02 & B & & & & & & & & & & & \\
\hline 72R-CC, 19-24 & 687.8 & 687.85 & 687.825 & B & & & & & & & & & & & \\
\hline $73 R-3,16-17$ & 692.47 & 692.48 & 692.475 & C & $M$ & & $\mathrm{~F}$ & & $\mathrm{R}$ & & & $\mathrm{F}$ & C & C & \\
\hline 73R-CC, 40-45 & 695.76 & 695.81 & 695.785 & C & $M$ & $\mathrm{R}$ & $\mathrm{F}$ & $\mathrm{R}$ & $R$ & & & $\mathrm{~F}$ & C & $C$ & \\
\hline 74R-CC, $14-15$ & 699.14 & 699.15 & 699.145 & B & & & & & & & & & & & \\
\hline 75R-1, 17-17 & 708.77 & 708.77 & 708.77 & C & $M$ & $\mathrm{R}$ & $\mathrm{F}$ & $\mathrm{R}$ & R & & & $\mathrm{F}$ & & & \\
\hline 75R-CC, 24-29 & 713.91 & 713.96 & 713.935 & B & & & & & & & & & & & \\
\hline $76 \mathrm{R}-6,52-52$ & 725.23 & 725.23 & 725.23 & $\mathrm{~F}$ & $\mathrm{P}$ & & $\mathrm{R}$ & $\mathrm{F}$ & $\mathrm{F}$ & $\mathrm{R}$ & $\mathrm{R}$ & & $\mathrm{F}$ & $\mathrm{F}$ & \\
\hline 76R-CC, 18-23 & 725.6 & 725.65 & 725.625 & B & & & & & & & & & & & \\
\hline 77R-CC, 27-32 & 728.3 & 728.36 & 728.33 & C & $M$ & $R$ & C & & & & & $\mathrm{F}$ & $\mathrm{C}$ & C & \\
\hline 78R-1, 78-79 & 738.18 & 738.18 & 738.18 & A & $M$ & & C & & $\mathrm{R}$ & & & $\mathrm{F}$ & C & C & \\
\hline 78R-CC, 11-16 & 744.08 & 744.13 & 744.105 & B & & & & & & & & & & & \\
\hline 79R-1, 12-13 & 747.12 & 747.13 & 747.125 & C & $M$ & $\mathrm{~F}$ & $\mathrm{~F}$ & $\mathrm{~F}$ & $\mathrm{R}$ & & & $\mathrm{F}$ & C & C & \\
\hline 79R-2, 89-90 & 749.35 & 749.36 & 749.355 & C & $M$ & $\mathrm{~F}$ & $\mathrm{~F}$ & $\mathrm{~F}$ & $\mathrm{R}$ & & & $\mathrm{F}$ & C & C & \\
\hline 79R-3, 97-98 & 750.86 & 750.88 & 750.87 & C & $\mathrm{M}$ & $\mathrm{F}$ & $\mathrm{F}$ & $\mathrm{F}$ & $\mathrm{R}$ & & & $\mathrm{F}$ & C & C & \\
\hline $79 R-5,82-83$ & 753.66 & 753.68 & 753.67 & C & $M$ & $\mathrm{~F}$ & $\mathrm{~F}$ & $\mathrm{~F}$ & $\mathrm{R}$ & & & $\mathrm{F}$ & C & C & \\
\hline 79R-CC, 8-12 & 755.42 & 755.46 & 755.44 & B & & & & & & & & & & & \\
\hline $80 \mathrm{R}-\mathrm{CC}, 21-23$ & 756.81 & 756.83 & 756.82 & B & & & & & & & & & & & \\
\hline 80R-CC, $21-23$ & 756.81 & 756.83 & 756.82 & B & & & & & & & & & & & \\
\hline $82 \mathrm{R}-2,74-75$ & 777.94 & 777.95 & 777.945 & B & & & & & & & & & & & \\
\hline $82 \mathrm{R}-6,6-6$ & 782.36 & 782.36 & 782.36 & B & & & & & & & & & & & \\
\hline $82 \mathrm{R}-\mathrm{CC}, 23-28$ & 783.37 & 783.42 & 783.395 & B & & & & & & & & & & & \\
\hline $83 \mathrm{R}-\mathrm{CC}, 0-5$ & 785.95 & 786 & 785.975 & B & & & & & & & & & & & \\
\hline $84 R-2,74-75$ & 797.23 & 797.24 & 797.235 & B & & & & & & & & & & & \\
\hline $84 R-6,31-32$ & 802.78 & 802.79 & 802.785 & B & & & & & & & & & & & \\
\hline 84R-CC, 10-15 & 804.38 & 804.43 & 804.405 & B & & & & & & & & & & & \\
\hline $85 R-3,66-67$ & 807.65 & 807.66 & 807.655 & A & $M$ & $\mathrm{~F}$ & $\mathrm{~F}$ & $\mathrm{~F}$ & $\mathrm{~F}$ & & & $\mathrm{~F}$ & C & C & \\
\hline $85 R-4,72-73$ & 809.21 & 809.22 & 809.215 & A & $M$ & $\mathrm{~F}$ & $\mathrm{~F}$ & $\mathrm{~F}$ & $\mathrm{~F}$ & & & $\mathrm{~F}$ & C & C & \\
\hline 85R-CC, 17-22 & 811.29 & 811.34 & 811.315 & B & & & & & & & & & & & \\
\hline 86R-CC, 9-14 & 822.49 & 822.54 & 822.515 & B & & & & & & & & & & & \\
\hline 87R-2, 85-86 & 826.26 & 826.27 & 826.265 & $\mathrm{~F}$ & $\mathrm{P}$ & & $\mathrm{R}$ & & & & & $\mathrm{R}$ & $\mathrm{F}$ & $\mathrm{F}$ & \\
\hline 87R-CC, 25-30 & 833.15 & 833.2 & 833.175 & B & & & & & & & & & & & \\
\hline 88R-1, 117-118 & 834.67 & 834.68 & 834.675 & $\mathrm{~F}$ & $\mathrm{P}$ & & $\mathrm{F}$ & $\mathrm{R}$ & $R$ & & & $\mathrm{~F}$ & $\mathrm{~F}$ & $\mathrm{~F}$ & \\
\hline $88 R-2,35-37$ & 835.21 & 835.23 & 835.22 & $\mathrm{~F}$ & $\mathrm{M}$ & & $\mathrm{F}$ & $\mathrm{R}$ & $R$ & & & $\mathrm{~F}$ & $\mathrm{~F}$ & $\mathrm{~F}$ & \\
\hline $88 \mathrm{R}-\mathrm{CC}, 0-5$ & 836.06 & 836.11 & 836.085 & $\mathrm{~F}$ & $\mathrm{M}$ & & $\mathrm{F}$ & $\mathrm{R}$ & $R$ & & & $\mathrm{~F}$ & $\mathrm{~F}$ & $\mathrm{~F}$ & \\
\hline 89R-3, 110-111 & 846.81 & 846.82 & 846.815 & B & & & & & & & & & & & \\
\hline $89 \mathrm{R}-5,24-25$ & 848.49 & 848.5 & 848.495 & $\mathrm{R}$ & $M$ & & & & $\mathrm{R}$ & & & & $\mathrm{R}$ & $\mathrm{R}$ & \\
\hline $89 \mathrm{R}-\mathrm{CC}, 0-3$ & 849.41 & 849.44 & 849.425 & B & & & & & & & & & & & \\
\hline 90R-CC, $18-20$ & 852.88 & 852.9 & 852.89 & B & & & & & & & & & & & \\
\hline 91R-CC, 24-29 & 870.02 & 870.07 & 870.045 & B & & & & & & & & & & & \\
\hline 91R-CC, 24-29 & 870.02 & 870.07 & 870.045 & B & & & & & & & & & & & \\
\hline 92R-CC, 20-25 & 874.97 & 875.02 & 874.995 & B & & & & & & & & & & & \\
\hline 93R-CC, 17-22 & 880.69 & 880.74 & 880.715 & B & & & & & & & & & & & \\
\hline $94 \mathrm{R}-4,29-30$ & 885.92 & 885.93 & 885.925 & A & $M$ & cf. & & & $\mathrm{F}$ & cf. & $\mathrm{F}$ & $\mathrm{F}$ & C cf. & $C$ & $\mathrm{R}$ \\
\hline 94R-CC, 13-18 & 886.89 & 886.94 & 886.915 & B & $M$ & & & & $\mathrm{~F}$ & & $\mathrm{~F}$ & $\mathrm{~F}$ & $\mathrm{C}$ & $\mathrm{C}$ & $\mathrm{R}$ \\
\hline 95R-CC, 17-22 & 895.66 & 895.72 & 895.69 & B & & & & & & & & & & & \\
\hline 96R-CC, 35-40 & 900.95 & 901 & 900.975 & B & & & & & & & & & & & \\
\hline 97R-CC, 15-20 & 911.68 & 911.73 & 911.705 & B & & & & & & & & & & & \\
\hline 98R-CC, 18-23 & 925.5 & 925.55 & 925.525 & B & & & & & & & & & & & \\
\hline $99 \mathrm{R}-3,52-53$ & 932.6 & 932.62 & 932.61 & B & & & & & & & & & & & \\
\hline
\end{tabular}


Table T6 (continued).

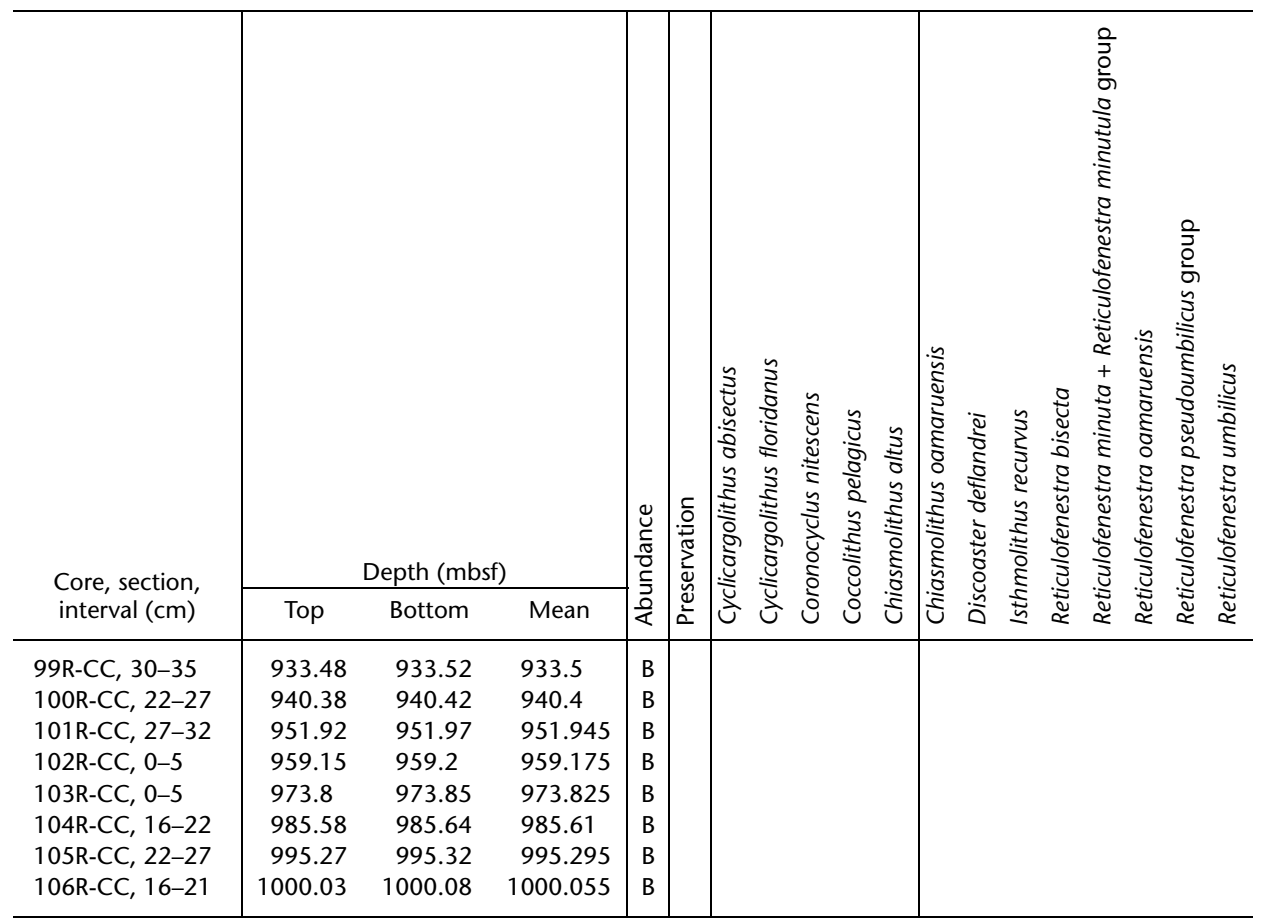

Notes: Abundance: $A=$ abundant, $C=$ common, $F=$ few, $R=$ rare, $B=$ barren. Preservation: $M=$ moderate, $P=$ poor. cf. $=$ confer. See "Biostratigraphy" in the "Methods" chapter for abundance and preservation definitions.

Table T7. Palynology, Hole U1356A. This table is available in an oversized format. 

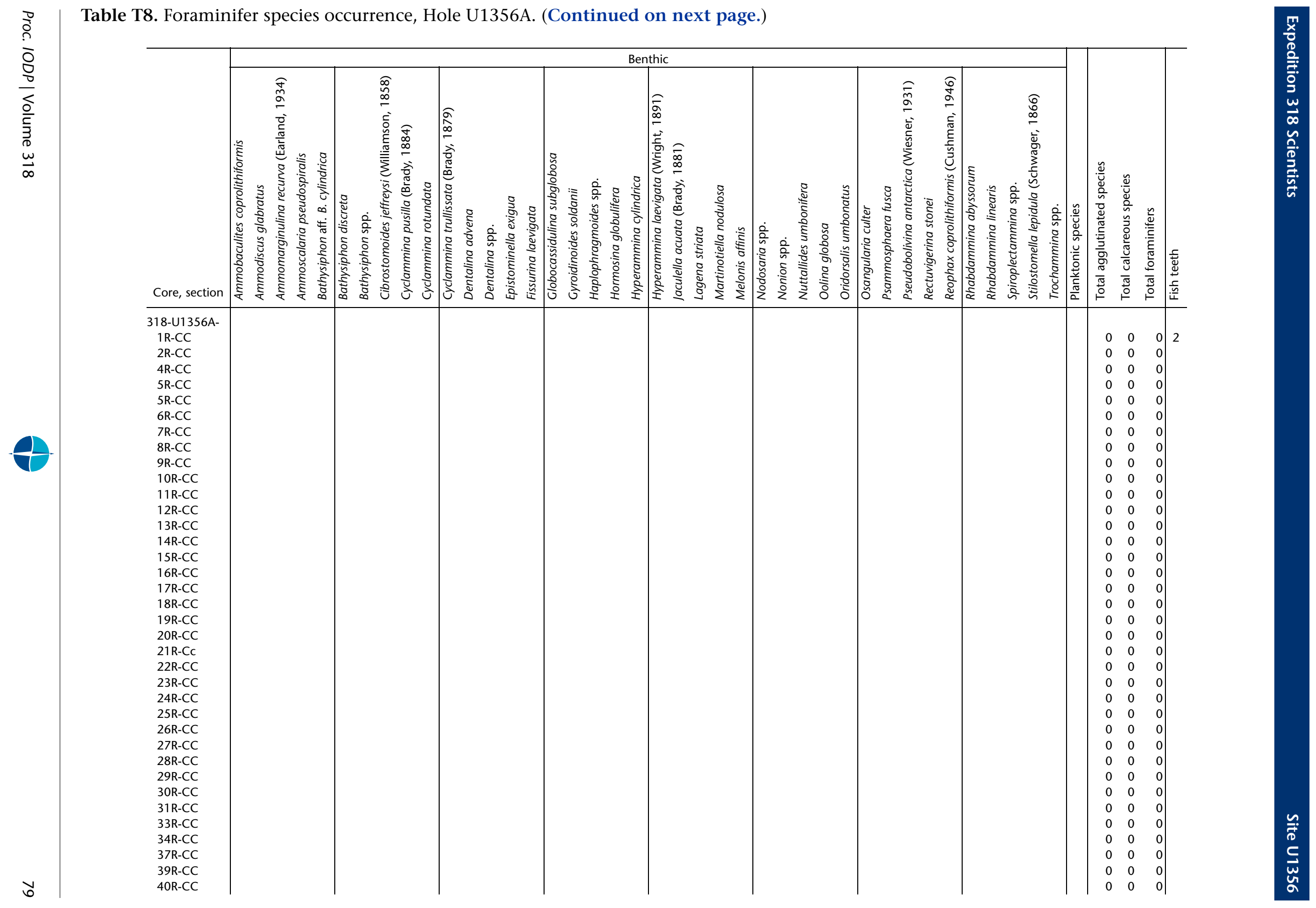


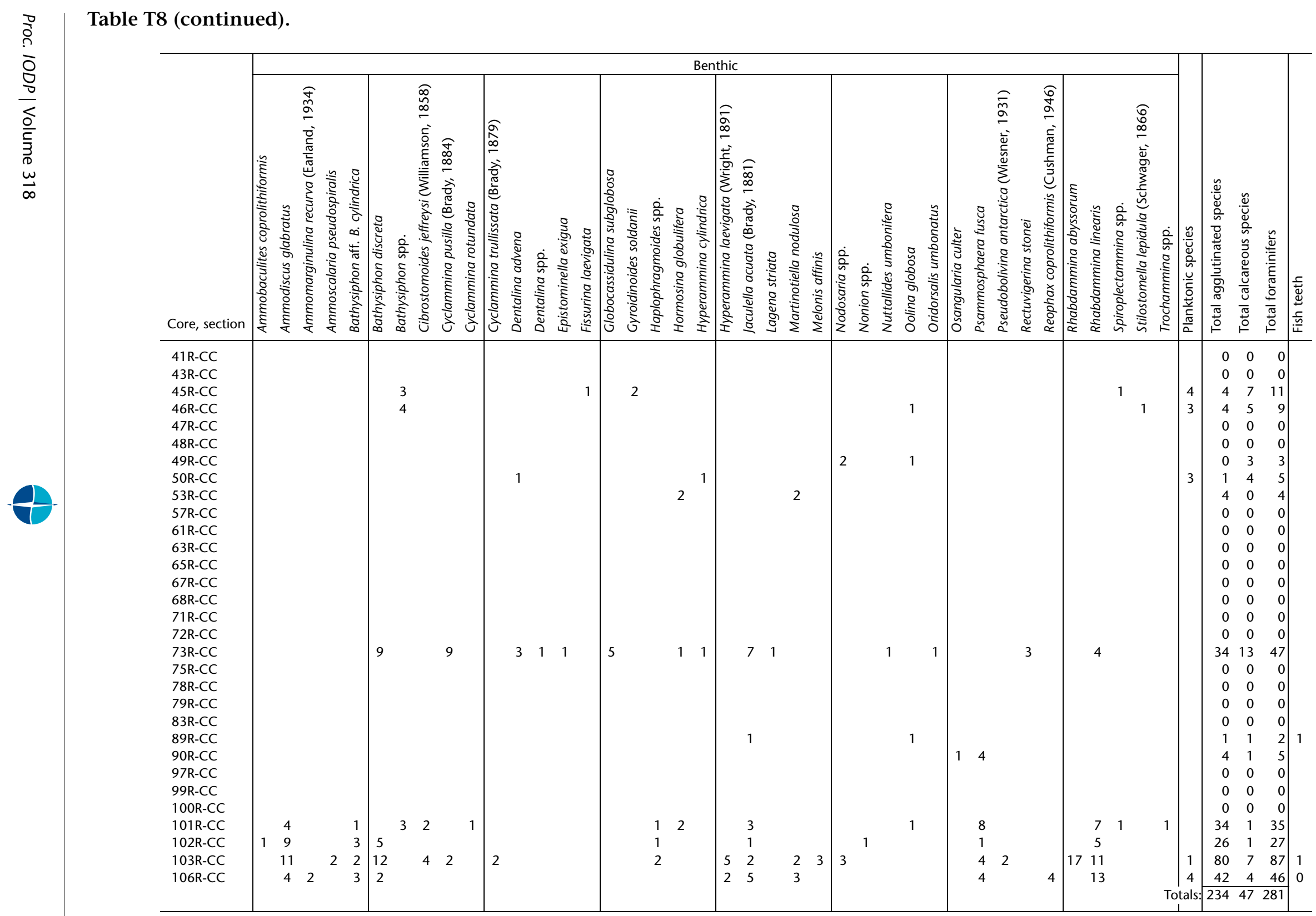


Table T9. Biostratigraphic events and chronostratigraphy, Hole U1356A. (See table notes.) (Continued on next page.)

\begin{tabular}{|c|c|c|c|c|c|c|c|c|c|}
\hline \multirow{3}{*}{$\begin{array}{l}\text { Age } \\
\text { source }\end{array}$} & \multirow[b]{3}{*}{ Event } & \multicolumn{2}{|c|}{ Age } & \multirow{2}{*}{\multicolumn{2}{|c|}{ Core, section, interval $(\mathrm{cm})$}} & \multirow{2}{*}{\multicolumn{3}{|c|}{ Depth (mbsf) }} & \multirow{3}{*}{$\begin{array}{c}\text { Depth } \\
\text { error } \\
(\mathrm{m})\end{array}$} \\
\hline & & \multirow{2}{*}{$\begin{array}{l}\text { Published } \\
\text { (Ma) }\end{array}$} & \multirow{2}{*}{$\begin{array}{l}\text { Error } \\
\text { (m.y.) }\end{array}$} & & & & & & \\
\hline & & & & Top & Bottom & Top & Bottom & Median & \\
\hline $\mathrm{R}$ & FO Helotholus vema & 4.20 & & $\begin{array}{l}\text { 318-U1356A- } \\
0\end{array}$ & $\begin{array}{c}318-U 1356 \mathrm{~A}- \\
1 \mathrm{R}-1,3-5\end{array}$ & 0.00 & 0.03 & 0.02 & 0.02 \\
\hline D & LO Rouxia peragalli & 4.67 & 0.09 & 0 & $1 \mathrm{R}-1,3-5$ & 0.00 & 0.03 & 0.02 & 0.02 \\
\hline D & LO Denticulopsis simonsenii & 4.89 & 0.06 & 0 & $1 \mathrm{R}-1,3-5$ & 0.00 & 0.03 & 0.02 & 0.02 \\
\hline D & FO Rouxia peragalli & 7.00 & 0.62 & $1 \mathrm{R}-1,3-5$ & $1 \mathrm{RCC}$ & 0.03 & 4.55 & 2.29 & 2.26 \\
\hline D & FO Fragilariopsis clementia & 7.03 & 0.68 & $1 \mathrm{R}-1,3-5$ & $1 \mathrm{RCC}$ & 0.03 & 4.55 & 2.29 & 2.26 \\
\hline D & FO Rouxia californica & 8.62 & 0.12 & $1 \mathrm{R}-1,3-5$ & $1 \mathrm{RCC}$ & 0.03 & 4.55 & 2.29 & 2.26 \\
\hline D & FO Thalassiosira inura & 4.74 & 0.03 & $1 \mathrm{R}-2,138-139$ & $1 \mathrm{RCC}$ & 2.86 & 4.55 & 3.71 & 0.84 \\
\hline D & FO Thalassiosira oliverana & 6.18 & 1.04 & $1 \mathrm{R}-2,138-139$ & $1 \mathrm{RCC}$ & 2.86 & 4.55 & 3.71 & 0.84 \\
\hline D & FO Thalassiosira torokina & 7.23 & 0.80 & $1 \mathrm{R}-2,138-139$ & $1 \mathrm{RCC}$ & 2.86 & 4.55 & 3.71 & 0.84 \\
\hline $\mathrm{R}$ & LO Cycladophora humerus & 10.40 & & $1 \mathrm{R}-\mathrm{CC}$ & $3 \mathrm{R}-\mathrm{CC}$ & 4.55 & 19.75 & 12.15 & 7.60 \\
\hline D & LO Denticulopsis ovata & 9.64 & 1.07 & $3 \mathrm{R}-\mathrm{CC}$ & $4 \mathrm{R}-\mathrm{CC}$ & 19.75 & 28.34 & 24.05 & 4.29 \\
\hline D & LO Denticulopsis dimorpha var. areolata & 10.25 & 0.53 & $3 \mathrm{R}-\mathrm{CC}$ & $4 \mathrm{R}-\mathrm{CC}$ & 19.75 & 28.34 & 24.05 & 4.29 \\
\hline D & LO Denticulopsis dimorpha & 10.28 & 0.49 & $3 \mathrm{R}-\mathrm{CC}$ & $4 \mathrm{R}-\mathrm{CC}$ & 19.75 & 28.34 & 24.05 & 4.29 \\
\hline D & FO Thalassiothrix miocenica & 10.14 & 0.44 & $4 \mathrm{R}-\mathrm{CC}$ & & 28.34 & & 28.34 & 0.00 \\
\hline D & FO Denticulopsis ovata & 11.09 & 0.01 & $6 \mathrm{R}-\mathrm{CC}$ & $7 \mathrm{R}-\mathrm{CC}$ & 47.38 & 56.94 & 52.16 & 4.78 \\
\hline D & FO Denticulopsis dimorpha var. & 10.31 & 0.53 & 7R-CC & 9R-CC & 56.94 & 76.21 & 66.58 & 9.63 \\
\hline D & FO Denticulopsis dimorpha & 12.50 & 0.04 & $8 \mathrm{R}-\mathrm{CC}$ & 9R-CC & 66.56 & 76.21 & 71.39 & 4.82 \\
\hline $\mathrm{R}$ & FO Cycladophoa spongothrax & 12.60 & & $10 \mathrm{R}-\mathrm{CC}$ & $12 \mathrm{R}-\mathrm{CC}$ & 85.85 & 109.28 & 97.57 & 11.72 \\
\hline D & FO Denticulopsis praedimorpha & 12.97 & 0.16 & $8 \mathrm{R}-\mathrm{CC}$ & $16 \mathrm{R}-\mathrm{CC}$ & 66.56 & 143.52 & 105.04 & 38.48 \\
\hline PM & Chron C5AA (y) & 13.02 & & $14 \mathrm{R}-5,80$ & $15 \mathrm{R}-1,10$ & 130.40 & 133.90 & 132.15 & 1.75 \\
\hline $\mathrm{R}$ & FO Actinomma golowini & 13.50 & & $14 \mathrm{R}-\mathrm{CC}$ & $15 \mathrm{R}-\mathrm{CC}$ & 130.65 & 141.70 & 136.18 & 5.52 \\
\hline $\mathrm{D}$ & FO Nitzschia denticuloides & 13.49 & 0.12 & $21 \mathrm{R}-\mathrm{CC}$ & $22-\mathrm{RCC}$ & 193.79 & 203.91 & 198.85 & 5.06 \\
\hline $\mathrm{R}$ & FO Cycladophora humerus & 14.10 & & $21 \mathrm{R}-\mathrm{CC}$ & $22 \mathrm{R}-\mathrm{CC}$ & 193.79 & 203.91 & 198.85 & 5.06 \\
\hline PM & Chron C5ACn (o) & 14.10 & & $22 \mathrm{R}-2,75$ & $22 \mathrm{R}-2,90$ & 203.15 & 203.30 & 203.23 & 0.08 \\
\hline D & FO Denticulopsis simonsenii & 14.16 & 0.01 & $23 \mathrm{R}-\mathrm{CC}$ & $24 \mathrm{R}-\mathrm{CC}$ & 212.02 & 222.30 & 217.16 & 5.14 \\
\hline D & LO Denticulopsis maccollumii & 14.33 & 0.04 & $24 \mathrm{R}-\mathrm{CC}$ & $25 \mathrm{R}-\mathrm{CC}$ & 222.30 & 229.90 & 226.10 & 3.80 \\
\hline $\mathrm{D}$ & FO Eucampia antarctica & 10.46 & 0.45 & $28 \mathrm{R}-\mathrm{CC}$ & $29 \mathrm{R}-\mathrm{CC}$ & 258.56 & 268.18 & 263.37 & 4.81 \\
\hline D & FO Actinocyclus ingens var. nodus & 14.60 & 0.11 & $28 \mathrm{R}-\mathrm{CC}$ & $29 \mathrm{R}-\mathrm{CC}$ & 258.56 & 268.18 & 263.37 & 4.81 \\
\hline PM & Chron CC5B.2n (y) & 15.03 & & $30 \mathrm{R}-2,50$ & $30 \mathrm{R}-2,75$ & 279.50 & 279.75 & 279.63 & 0.13 \\
\hline D & FO Denticulopsis lauta & 15.69 & 0.01 & $31 \mathrm{R}-\mathrm{CC}$ & $33 \mathrm{R}-\mathrm{CC}$ & 287.06 & 307.64 & 297.35 & 10.29 \\
\hline D & LO Cavitatus jouseanus & 14.47 & 0.07 & $34 \mathrm{R}-\mathrm{CC}$ & $35 \mathrm{R}-\mathrm{CC}$ & 321.13 & 331.44 & 326.29 & 5.15 \\
\hline PM & Chron C5C.1n (o) & 16.27 & & $39 \mathrm{R}-1,35$ & $39 \mathrm{R}-1,65$ & 363.95 & 364.25 & 364.10 & 0.15 \\
\hline $\mathrm{D}$ & FO Actinocyclus ingens & 15.87 & 0.03 & $38 \mathrm{R}-\mathrm{CC}$ & $41 \mathrm{R}-\mathrm{CC}$ & 354.05 & 386.95 & 370.50 & 16.45 \\
\hline $\mathrm{R}$ & FO Eucyrtidium punctatum & 17.00 & & $41 \mathrm{R}-\mathrm{CC}$ & & & 386.95 & 386.95 & 0.00 \\
\hline D & FO Denticulopsis maccollumii & 17.01 & 0.14 & $41 \mathrm{R}-\mathrm{CC}$ & & 386.95 & & 386.95 & 0.00 \\
\hline PM & Chron C5Cn.3n (o) & 16.72 & & $42 \mathrm{R}-2,59$ & $43 \mathrm{R}-1,25$ & 394.21 & 402.25 & 398.23 & 4.02 \\
\hline PL & FO Impagidinium patulum & 16.20 & & $43 \mathrm{R}-\mathrm{CC}, 21-26$ & $44 \mathrm{R}-\mathrm{CC}, 25-28$ & 404.90 & 412.60 & 408.75 & 3.85 \\
\hline $\mathrm{F}$ & LO Globigerina euapertura & 23.00 & & & $45 \mathrm{R}-\mathrm{CC}$ & & 422.27 & 422.27 & 0.00 \\
\hline $\mathrm{F}$ & LO Catapsydrax dissimilis & 17.15 & & 46R-CC & & 434.66 & & 434.66 & 0.00 \\
\hline PM & Chron C5Dn (y) & 17.235 & & $44 \mathrm{R}-1,60$ & $45 \mathrm{R}-1,15$ & 412.20 & 421.35 & 416.78 & 4.575 \\
\hline \multirow[t]{2}{*}{ PM } & Chron C5Dn (o) & 17.533 & & $46 \mathrm{R}-2,60$ & $46 \mathrm{R}-2,65$ & 432.84 & 432.89 & 432.87 & 0.02 \\
\hline & Oligocene-Miocene boundary (in hiatus) & 23.03 & & $46 \mathrm{R}-\mathrm{CC}$ & $47 \mathrm{R}-3,126-127$ & 434.66 & 444.59 & 439.63 & 4.97 \\
\hline $\mathrm{F}$ & LO Globigerina labiacrassata & 26.80 & & & $46 \mathrm{R}-\mathrm{CC}$ & & 434.66 & 434.66 & 0.00 \\
\hline $\mathrm{CN}$ & LO Reticulofenestra bisecta & 23.12 & & $47 \mathrm{R}-3,126-127$ & $47 R-4,31-32$ & 444.59 & 444.94 & 444.77 & 0.18 \\
\hline $\mathrm{CN}$ & LO Chiasmolithus altus & 25.56 & & $47 \mathrm{R}-\mathrm{CC}$ & $48 \mathrm{R}-1,6-7$ & 446.02 & 449.97 & 448.00 & 1.98 \\
\hline $\mathrm{F}$ & FO Globigerina connecta & 21.50 & & & $50 \mathrm{R}-\mathrm{CC}$ & & 469.86 & 469.86 & 0.00 \\
\hline $\mathrm{CN}$ & LO Reticulofenesta bisecta & 23.00 & & $50 \mathrm{R}-\mathrm{CC}$ & $55 \mathrm{R}-\mathrm{CC}$ & 469.86 & 519.11 & 494.49 & 24.63 \\
\hline $\mathrm{PL}$ & FO Filisphaera filifera & 23.95 & & $58 \mathrm{R}-\mathrm{CC}$ & $59 \mathrm{R}-\mathrm{CC}$ & 546.29 & 556.73 & 551.51 & 5.22 \\
\hline
\end{tabular}


Table T9 (continued).

\begin{tabular}{|c|c|c|c|c|c|c|c|c|c|}
\hline \multirow{3}{*}{$\begin{array}{c}\text { Age } \\
\text { source }\end{array}$} & \multirow[b]{3}{*}{ Event } & \multicolumn{2}{|c|}{ Age } & \multirow{2}{*}{\multicolumn{2}{|c|}{ Core, section, interval $(\mathrm{cm})$}} & \multirow{2}{*}{\multicolumn{3}{|c|}{ Depth (mbsf) }} & \multirow{3}{*}{$\begin{array}{l}\text { Depth } \\
\text { error } \\
\text { (m) }\end{array}$} \\
\hline & & \multirow{2}{*}{$\begin{array}{l}\text { Published } \\
\text { (Ma) }\end{array}$} & \multirow{2}{*}{$\begin{array}{l}\text { Error } \\
\text { (m.y.) }\end{array}$} & & & & & & \\
\hline & & & & Top & Bottom & Top & Bottom & Median & \\
\hline PM & Chron C7An (o) & 25.09 & & $68 \mathrm{R}-2,75$ & $68 \mathrm{R}-2,80$ & 643.65 & 643.70 & 643.68 & 0.03 \\
\hline PM & Chron C8n.1n (y) & 25.30 & & $69 \mathrm{R}-2,15$ & $69 \mathrm{R}-2,25$ & 652.50 & 652.60 & 652.55 & 0.05 \\
\hline PM & Chron C8n.2n (o) & 26.15 & & $71 \mathrm{R}-6,115$ & $72 \mathrm{R}-1,10$ & 678.06 & 679.90 & 678.98 & 0.92 \\
\hline $\mathrm{F}$ & FO Rectuvigerina stonei & 16.10 & & 73R-CC & & 695.76 & & 695.76 & 0.00 \\
\hline $\mathrm{F}$ & LO Rectuvigerina stonei & 28.50 & & & $73 \mathrm{R}-\mathrm{CC}$ & & 695.76 & 695.76 & 0.00 \\
\hline PM & Chron C9n (o) & 27.83 & & $76 \mathrm{R}-6,35$ & $76 \mathrm{R}-6,40$ & 725.06 & 725.11 & 725.09 & 0.02 \\
\hline PM & Chron C11n.1n (o) & 29.74 & & $82 \mathrm{R}-6,35$ & $82 \mathrm{R}-6,40$ & 782.65 & 782.70 & 782.68 & 0.03 \\
\hline PM & Chron C12n (y) & 30.63 & & $86 \mathrm{R}-2,115$ & $86 \mathrm{R}-7,10$ & 816.93 & 821.88 & 819.41 & 2.48 \\
\hline $\mathrm{CN}$ & LO Reticulofenestra umbilicus & 31.56 & & 93R-CC & $94 \mathrm{R}-4,29-30$ & 880.72 & 885.93 & 883.33 & 2.60 \\
\hline $\mathrm{CN}$ & LO Isthmolithus recurvus & 32.63 & & $93 \mathrm{R}-\mathrm{CC}$ & $94 \mathrm{R}-4,29-30$ & 880.72 & 885.93 & 883.33 & 2.60 \\
\hline PL & LO Apectodinium spp. & 48.60 & & 96R-CC & 97R-CC & 886.89 & 892.00 & 889.45 & 2.55 \\
\hline \multirow[t]{2}{*}{$\mathrm{PL}$} & FO “Forma T" & 33.60 & & $94 \mathrm{R}-\mathrm{CC}$ & 95R-1, 97-100 & 886.94 & 892.00 & 889.47 & 2.53 \\
\hline & Eocene-Oligocene boundary (in hiatus) & 33.90 & & $94 \mathrm{R}-\mathrm{CC}$ & $95 \mathrm{R}-1,97-100$ & 886.94 & 892.00 & 889.47 & 2.53 \\
\hline $\mathrm{PL}$ & LO Membranophoridium perforatum & 47.90 & & 95R-1, 97-100 & $95 \mathrm{R}-3,25-26$ & 892.00 & 894.10 & 893.05 & 1.05 \\
\hline PL & FO Charlesdowniea edwardsii & 50.00 & & 95R-CC & 96R-CC & 895.66 & 900.95 & 898.31 & 2.65 \\
\hline PL & FO Arachnodinium antarcticum & 51.50 & & 97R-CC & $98 \mathrm{R}-1,33-34$ & 911.68 & 925.50 & 918.59 & 6.91 \\
\hline $\mathrm{PL}$ & LO Palaeocystodinium golzowense & 50.80 & 0.20 & 97R-CC & $98 \mathrm{R}-1,33-34$ & 911.68 & 925.50 & 918.59 & 6.91 \\
\hline PM & Chron C23n.1n (y) & 50.43 & & $98 \mathrm{R}-3,120$ & $98 \mathrm{R}-3,125$ & 923.44 & 923.49 & 923.47 & 0.02 \\
\hline PM & Chron C23n.1n (o) & 50.73 & & $99 \mathrm{R}-1,35$ & $99 \mathrm{R}-1,80$ & 929.62 & 929.65 & 929.64 & 0.01 \\
\hline $\mathrm{PL}$ & FO Hystrichokolpoma spinosa & 51.90 & & 99R-CC, 30-35 & $100 \mathrm{R}-1,75-76$ & 933.52 & 939.00 & 936.26 & 2.74 \\
\hline $\mathrm{PL}$ & LO Dracodinium waipawaense & 52.60 & & 100R-1, 75-76 & $101 \mathrm{R}-\mathrm{CC}$ & 939.00 & 951.92 & 945.46 & 6.46 \\
\hline PL & FO Octodinium askiniae & 53.70 & 0.20 & 100R-1, 75-76 & $101 \mathrm{R}-\mathrm{CC}$ & 939.00 & 951.92 & 945.46 & 6.46 \\
\hline PM & Chron C23n.2n (y) & 51.06 & & 100R-1, 100 & 101R-1, 15 & 940.10 & 948.95 & 944.53 & 4.43 \\
\hline PM & Chron C23n.2n (o) & 51.90 & & $101 \mathrm{R}-1,100$ & $101 \mathrm{R}-2,90$ & 949.80 & 951.20 & 950.50 & 0.70 \\
\hline $\mathrm{PL}$ & FO Hystrichokolpoma rigaudiae & 53.60 & 0.20 & 101R-CC & $102 \mathrm{R}-\mathrm{CC}$ & 951.92 & 959.15 & 955.54 & 3.62 \\
\hline PM & Chron C24n.1n (y) & 52.65 & & $102 \mathrm{R}-1,60$ & $103 \mathrm{R}-1,65$ & 959.00 & 968.65 & 963.83 & 4.82 \\
\hline PM & Chron C24n.1n (o) & 53.00 & & 104R-1, 95 & $104 \mathrm{R}-1,100$ & 978.55 & 978.60 & 978.58 & 0.02 \\
\hline PM & Chron C24n.3n (y) & 53.29 & & 104R-6, 65 & $105 \mathrm{R}-1,10$ & 985.36 & 987.30 & 986.33 & 0.97 \\
\hline PL & Acme Apectodinium spp. & 53.80 & 0.20 & 105R-CC & $105 \mathrm{R}-\mathrm{CC}$ & 995.27 & 995.27 & 995.27 & 0.00 \\
\hline PM & Chron C24n.3n (o) & 53.81 & & 106R-1, 95 & 106R-1, 100 & 997.75 & 997.80 & 997.78 & 0.02 \\
\hline $\mathrm{F}$ & LO Acarinina wilcoxensis & 51.70 & & & 106R-CC & & 1000.03 & 1000.03 & 0.00 \\
\hline $\mathrm{F}$ & FO Acarinina wilcoxensis & 55.55 & & 106R-CC & & 1000.03 & & 1000.03 & 0.00 \\
\hline
\end{tabular}

Notes: Age source: See "Paleomagnetism." These data are used to plot Figure F4. $\mathrm{D}=$ diatoms, $\mathrm{R}=$ radiolarians, $\mathrm{CN}=$ calcareous nannofossils, $\mathrm{PL}=$ palynomorphs, $\mathrm{F}=$ foraminifers, $\mathrm{PM}=$ paleomagnetic event. FO = first occurrence, $\mathrm{LO}=$ last occurrence, $\mathrm{y}=$ young, $\mathrm{o}=$ old 
Table T10. Molecular biomarkers in fraction N1, Site U1356. (See table note.) (Continued on next page.)

\begin{tabular}{|c|c|c|c|c|c|c|c|c|c|c|c|c|c|c|c|c|c|c|c|c|c|c|c|c|c|}
\hline \multirow{4}{*}{$\begin{array}{l}\text { Core, section, } \\
\text { interval }(\mathrm{cm})\end{array}$} & \multirow{3}{*}{\multicolumn{2}{|c|}{ Depth (mbsf) }} & \multicolumn{22}{|c|}{$n$-alkanes } & \multirow{4}{*}{$\begin{array}{c}\text { Total } \\
\text { hopanes }\end{array}$} \\
\hline & & & \multirow{2}{*}{\multicolumn{17}{|c|}{ Compounds [ng/g dry sediment] }} & \multicolumn{5}{|c|}{ Indexes } & \\
\hline & & & & & & & & & & & & & & & & & & & & \multirow{2}{*}{ 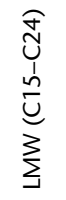 } & \multirow{2}{*}{ 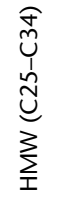 } & \multirow{2}{*}{ 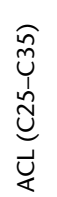 } & \multirow{2}{*}{$\sum_{\substack{\sum_{1} \\
\sum}}^{3}$} & & \\
\hline & Top & Bottom & $\mathrm{C} 15$ & $\mathrm{C} 16$ & $\mathrm{C} 17$ & $\mathrm{C} 18$ & C19 & $\mathrm{C} 20$ & $\mathrm{C} 21$ & $\mathrm{C} 22$ & $\mathrm{C} 23$ & C24 & $\mathrm{C} 25$ & $\mathrm{C} 26$ & $\mathrm{C} 27$ & $\mathrm{C} 28$ & C29 & $\mathrm{C} 30$ & C31 & & & & & & \\
\hline \multicolumn{26}{|l|}{$\begin{array}{l}\text { 318-U1356A- } \\
\text { Miocene }\end{array}$} \\
\hline $2 \mathrm{R}-3,50-51$ & 13.00 & 13.01 & 0 & 0 & 0 & 1 & 1 & 2 & 2 & 3 & 3 & 3 & 3 & 0 & 0 & 0 & 0 & 0 & 0 & 16 & 3 & 25 & 0 & & 0 \\
\hline $15 R-3,83-84$ & 137.63 & 137.64 & 0 & 0 & 0 & 0 & 0 & 1 & 2 & 2 & 2 & 1 & 2 & 1 & 2 & 0 & 0 & 0 & 0 & 8 & 6 & 26 & 1 & 2.5 & 0 \\
\hline $30 R-3,46-48$ & 280.96 & 280.98 & 0 & 0 & 0 & 0 & 0 & 0 & 0 & 0 & 0 & 0 & 0 & 0 & 0 & 0 & 0 & 0 & 0 & 0 & 0 & & & & 0 \\
\hline $41 \mathrm{R}-3,29-31$ & 386.09 & 386.11 & 0 & 0 & 0 & 0 & 0 & 0 & 1 & 1 & 1 & 0 & 1 & 0 & 0 & 0 & 0 & 0 & 0 & 3 & 1 & 25 & 0 & & 0 \\
\hline $47 \mathrm{R}-3,26-28$ & 443.58 & 443.60 & 0 & 0 & 0 & 0 & 4 & 20 & 40 & 18 & 31 & 51 & 45 & 31 & 23 & 28 & 0 & 0 & 0 & 165 & 127 & 26 & 1 & 1.0 & 18 \\
\hline \multirow[t]{7}{*}{$47 \mathrm{R}-4,27-29$} & 444.89 & 444.91 & 0 & 0 & 0 & 0 & 0 & 0 & 0 & 0 & 0 & 0 & 0 & 0 & 0 & 0 & 0 & 0 & 0 & 0 & 0 & & & & 0 \\
\hline & & Summary & & & & & & & & & & & & & & & & & & & & & & & \\
\hline & & Minimum: & 0 & 0 & 0 & 0 & 0 & 0 & 0 & 0 & 0 & 0 & 0 & 0 & 0 & 0 & 0 & 0 & 0 & 0 & 0 & 25 & 0 & 1.0 & 0 \\
\hline & & Maximum: & 0 & 0 & 0 & 1 & 4 & 20 & 40 & 18 & 31 & 51 & 45 & 31 & 23 & 28 & 0 & 0 & 0 & 165 & 127 & 26 & 1 & 2.5 & 18 \\
\hline & & Average: & 0 & 0 & 0 & 0 & 1 & 4 & 8 & 4 & 6 & 9 & 8 & 5 & 4 & 5 & 0 & 0 & 0 & 32 & 23 & 26 & 0 & 1.8 & 3 \\
\hline & Standard & deviation: & 0 & 0 & 0 & 0 & 2 & 8 & 16 & 7 & 12 & 21 & 18 & 12 & 9 & 12 & 0 & 0 & 0 & 65 & 51 & 1 & 0 & 1.1 & 7 \\
\hline & & Median: & 0 & 0 & 0 & 0 & 0 & 1 & 1 & 1 & 2 & 1 & 2 & 0 & 0 & 0 & 0 & 0 & 0 & 6 & 2 & 25 & 0 & 1.8 & 0 \\
\hline \multicolumn{26}{|l|}{ Oligocene } \\
\hline 51R-1, 129-131 & 479.89 & 479.91 & 0 & 0 & 0 & 0 & 0 & 2 & 1 & 3 & 3 & 2 & 2 & 1 & 1 & 0 & 0 & 0 & 0 & 12 & 4 & 26 & 0 & 1.6 & 0 \\
\hline $58 \mathrm{R}-\mathrm{CC}, 21-23$ & 546.20 & 546.22 & 0 & 0 & 0 & 0 & 0 & 9 & 5 & 6 & 5 & 4 & 3 & 0 & 0 & 0 & 0 & 0 & 0 & 28 & 3 & 25 & 0 & & 0 \\
\hline $63 \mathrm{R}-2,25-27$ & 595.03 & 595.05 & 0 & 0 & 0 & 0 & 5 & 8 & 8 & 18 & 13 & 17 & 10 & 10 & 4 & 12 & 0 & 0 & 0 & 69 & 36 & 26 & 1 & 0.6 & 3 \\
\hline $63 R-4,37-39$ & 597.72 & 597.74 & 0 & 0 & 0 & 0 & 4 & 8 & 14 & 17 & 15 & 9 & 14 & 5 & 8 & 0 & 0 & 0 & 0 & 66 & 27 & 26 & 0 & 2.9 & 6 \\
\hline 73R-CC, 33-39 & 695.73 & 695.75 & 0 & 0 & 0 & 0 & 0 & 0 & 0 & 0 & 0 & 0 & 0 & 0 & 0 & 0 & 0 & 0 & 0 & 0 & 0 & & & & 0 \\
\hline $87 R-2,83-85$ & 826.24 & 826.26 & 0 & 0 & 0 & 0 & 0 & 0 & 0 & 0 & 0 & 0 & 0 & 0 & 0 & 0 & 0 & 0 & 0 & 0 & 0 & & & & 0 \\
\hline \multirow[t]{7}{*}{$89 R-3,27-29$} & 845.98 & 846.00 & 0 & 0 & 0 & 0 & 8 & 14 & 0 & 23 & 15 & 9 & 18 & 7 & 10 & 0 & 0 & 0 & 0 & 69 & 35 & 26 & 1 & 2.9 & 6 \\
\hline & & Summary & & & & & & & & & & & & & & & & & & & & & & & \\
\hline & & Minimum: & 0 & 0 & 0 & 0 & 0 & 0 & 0 & 0 & 0 & 0 & 0 & 0 & 0 & 0 & 0 & 0 & 0 & 0 & 0 & 25 & 0 & 0.6 & 0 \\
\hline & & Maximum: & 0 & 0 & 0 & 0 & 8 & 14 & 14 & 23 & 15 & 17 & 18 & 10 & 10 & 12 & 0 & 0 & 0 & 69 & 36 & 26 & 1 & 2.9 & 6 \\
\hline & & Average: & 0 & 0 & 0 & 0 & 3 & 6 & 4 & 11 & 8 & 6 & 7 & 4 & 4 & 2 & 0 & 0 & 0 & 39 & 17 & 26 & 0 & 2.2 & 3 \\
\hline & Standard & deviation: & 0 & 0 & 0 & 0 & 3 & 5 & 5 & 10 & 7 & 6 & 7 & 4 & 4 & 5 & 0 & 0 & 0 & 33 & 17 & 0 & 0 & 1.1 & 3 \\
\hline & & Median: & 0 & 0 & 0 & 0 & 0 & 8 & 1 & 6 & 5 & 4 & 3 & 1 & 1 & 0 & 0 & 0 & 0 & 28 & 4 & 26 & 0 & 2.2 & 0 \\
\hline
\end{tabular}


Table T10 (continued).

\begin{tabular}{|c|c|c|c|c|c|c|c|c|c|c|c|c|c|c|c|c|c|c|c|c|c|c|c|c|c|}
\hline \multirow{4}{*}{$\begin{array}{l}\text { Core, section, } \\
\text { interval }(\mathrm{cm})\end{array}$} & \multirow{3}{*}{\multicolumn{2}{|c|}{ Depth (mbsf) }} & \multicolumn{22}{|c|}{$n$-alkanes } & \multirow{4}{*}{$\begin{array}{c}\text { Total } \\
\text { hopanes }\end{array}$} \\
\hline & & & \multirow{2}{*}{\multicolumn{17}{|c|}{ Compounds [ng/g dry sediment] }} & \multicolumn{5}{|c|}{ Indexes } & \\
\hline & & & & & & & & & & & & & & & & & & & & \multirow{2}{*}{ 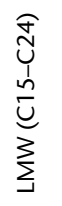 } & \multirow[t]{2}{*}{ 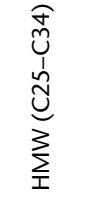 } & \multirow{2}{*}{ 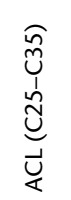 } & \multirow{2}{*}{$\sum_{\substack{\sum_{1} \\
\sum}}^{3}$} & \multirow{2}{*}{ 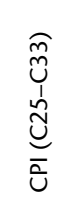 } & \\
\hline & Top & Bottom & $\mathrm{C} 15$ & $\mathrm{C} 16$ & $\mathrm{C} 17$ & $\mathrm{C} 18$ & C19 & $\mathrm{C} 20$ & $\mathrm{C} 21$ & $\mathrm{C} 22$ & $\mathrm{C} 23$ & C24 & $\mathrm{C} 25$ & $\mathrm{C} 26$ & $\mathrm{C} 27$ & $\mathrm{C} 28$ & C29 & C30 & C31 & & & & & & \\
\hline \multicolumn{26}{|l|}{ Eocene } \\
\hline 95R-CC, 0-2 & 895.50 & 895.52 & 0 & 0 & 0 & 0 & 0 & 8 & 19 & 32 & 108 & 70 & 248 & 156 & 340 & 42 & 670 & 351 & 2087 & 641 & 3489 & 28 & 3 & 7.8 & 808 \\
\hline $98 \mathrm{R}-3,71-73$ & 922.95 & 922.97 & 0 & 0 & 0 & 0 & 0 & 0 & 0 & 0 & 101 & 66 & 231 & 0 & 339 & 0 & 632 & 355 & 1938 & 398 & 3264 & 28 & 5 & 12.5 & 580 \\
\hline 99R-3, 37-39 & 932.46 & 932.48 & 0 & 0 & 0 & 0 & 0 & 0 & 0 & 0 & 0 & 0 & 0 & 0 & 20 & 3 & 36 & 39 & 46 & 0 & 187 & 28 & & 3.2 & 4 \\
\hline $101 \mathrm{R}-2,57-59$ & 950.87 & 950.89 & 0 & 0 & 0 & 0 & 0 & 24 & 20 & 57 & 79 & 37 & 90 & 55 & 119 & 0 & 158 & 0 & 166 & 363 & 515 & 28 & 2 & & 98 \\
\hline $103 \mathrm{R}-1,54-56$ & 968.54 & 968.56 & 0 & 0 & 0 & 0 & 0 & 0 & 0 & 0 & 0 & 0 & 0 & 0 & 0 & 0 & 0 & 0 & 0 & 0 & 0 & & & & 7 \\
\hline $103 R-3,53-55$ & 971.53 & 971.55 & 0 & 0 & 0 & 0 & 0 & 21 & 0 & 40 & 46 & 18 & 57 & 51 & 49 & 0 & 0 & 0 & 0 & 233 & 49 & 25 & 0 & & 655 \\
\hline 104R-2, 64-66 & 979.70 & 979.72 & 0 & 0 & 0 & 0 & 0 & 0 & 0 & 0 & 0 & 0 & 0 & 0 & 0 & 0 & 0 & 0 & 0 & 0 & 0 & & & & 0 \\
\hline 104R-4, 79-81 & 982.81 & 982.83 & 0 & 0 & 0 & 0 & 0 & 22 & 85 & 76 & 0 & 41 & 88 & 67 & 74 & 60 & 149 & 0 & 71 & 378 & 354 & 27 & 1 & 3.7 & 693 \\
\hline 104R-6, 34-36 & 985.05 & 985.07 & 0 & 0 & 0 & 0 & 0 & 0 & 0 & 0 & 0 & 0 & 0 & 0 & 0 & 0 & 0 & 0 & 0 & 0 & 0 & & & & 0 \\
\hline $105 R-3,53-55$ & 990.64 & 990.66 & 0 & 0 & 0 & 0 & 0 & 0 & 0 & 0 & 0 & 0 & 0 & 0 & 0 & 0 & 0 & 0 & 0 & 0 & 0 & & & & 8 \\
\hline 105R-4, 59-60 & 992.08 & 992.09 & 0 & 0 & 0 & 0 & 0 & 9 & 26 & 0 & 55 & 30 & 25 & 31 & 43 & 29 & 37 & 0 & 0 & 175 & 109 & 26 & 1 & 2.1 & 84 \\
\hline $106 \mathrm{R}-2,82-84$ & \multicolumn{24}{|c|}{ Summary } & 0 \\
\hline \multicolumn{3}{|r|}{ Minimum: } & 0 & 0 & 0 & 0 & 0 & 0 & 0 & 0 & 0 & 0 & 0 & 0 & 0 & 0 & 0 & 0 & 0 & 0 & 0 & 25 & 0 & 2.1 & 0 \\
\hline \multirow{2}{*}{\multicolumn{3}{|c|}{$\begin{array}{l}\text { Maximum: } \\
\text { Average: }\end{array}$}} & 0 & 0 & 0 & 0 & 0 & 24 & 85 & 76 & 108 & 70 & 248 & 156 & 340 & 60 & 670 & 355 & 2087 & 641 & 3489 & 28 & 5 & 12.5 & 808 \\
\hline & & & 0 & 0 & 0 & 0 & 0 & 7 & 13 & 17 & 32 & 22 & 62 & 30 & 82 & 11 & 140 & 62 & 359 & 182 & 664 & 27 & 2 & 5.9 & 245 \\
\hline \multicolumn{3}{|c|}{ Standard deviation: } & 0 & 0 & 0 & 0 & 0 & 10 & 25 & 27 & 43 & 27 & 90 & 47 & 126 & 21 & 245 & 136 & 774 & 220 & 1278 & 1 & 2 & 4.3 & 330 \\
\hline \multicolumn{3}{|r|}{ Median: } & 0 & 0 & 0 & 0 & 0 & 0 & 0 & 0 & 0 & 9 & 12 & 0 & 31 & 0 & 18 & 0 & 0 & 88 & 79 & 28 & 1 & 3.7 & 46 \\
\hline
\end{tabular}

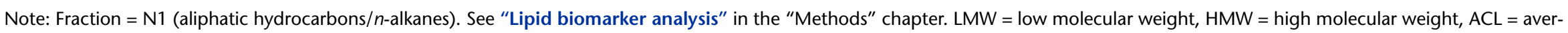
age chain length, $\mathrm{CPI}=$ carbon preference index. 
Table T11. Molecular biomarkers in fraction N3, Site U1356. (See table notes.)

\begin{tabular}{|c|c|c|c|c|c|c|c|}
\hline \multirow{2}{*}{$\begin{array}{l}\text { Core, section, } \\
\text { interval }(\mathrm{cm})\end{array}$} & \multicolumn{2}{|c|}{ Depth (mbsf) } & \multicolumn{2}{|c|}{ Detected by GC-MS } & \multicolumn{3}{|c|}{$\begin{array}{l}\text { Alkenone compounds } \\
\text { (ng/g dry sediment) }\end{array}$} \\
\hline & Top & Bottom & Scan mode & SIM mode & C $37: 2$ & C38:2 & C39:2 \\
\hline \multicolumn{8}{|l|}{ 318-U1356A- } \\
\hline \multicolumn{8}{|l|}{ Miocene } \\
\hline $2 \mathrm{R}-3,50-51$ & 13.00 & 13.01 & $\mathrm{~N}$ & $\mathrm{~N}$ & 0.0 & 0.0 & 0.5 \\
\hline $15 R-3,83-84$ & 137.63 & 137.64 & $\mathrm{~N}$ & $\mathrm{~N}$ & 0.0 & 0.0 & 0.0 \\
\hline 30R-3, 46-48 & 280.96 & 280.98 & $\mathrm{~N}$ & $\mathrm{~N}$ & 0.0 & 0.0 & 0.0 \\
\hline $41 \mathrm{R}-3,29-31$ & 386.09 & 386.11 & $\mathrm{~N}$ & $\mathrm{~N}$ & 0.0 & 0.0 & 0.0 \\
\hline $47 \mathrm{R}-3,26-28$ & 443.58 & 443.60 & $\mathrm{~N}$ & $\mathrm{~N}$ & 0.0 & 0.0 & 0.0 \\
\hline $47 \mathrm{R}-4,27-29$ & 444.89 & 444.91 & $\mathrm{~N}$ & $\mathrm{~N}$ & 0.0 & 0.0 & 0.0 \\
\hline \multicolumn{8}{|l|}{ Summary } \\
\hline Minimum: & & & & & 0.0 & 0.0 & 0.0 \\
\hline Maximum: & & & & & 0.0 & 0.0 & 0.5 \\
\hline Average: & & & & & 0.0 & 0.0 & 0.1 \\
\hline Standard deviation: & & & & & 0.0 & 0.0 & 0.2 \\
\hline Median: & & & & & 0.0 & 0.0 & 0.0 \\
\hline \multicolumn{8}{|l|}{ Oligocene } \\
\hline 51R-1, 129-131 & 479.89 & 479.91 & $\mathrm{~N}$ & $\mathrm{~N}$ & 0.0 & 0.0 & 0.0 \\
\hline 58R-CC, 21-23 & 546.20 & 546.22 & $\mathrm{~N}$ & $\mathrm{~N}$ & 0.0 & 0.0 & 0.0 \\
\hline $63 R-2,25-27$ & 595.03 & 595.05 & $\mathrm{~N}$ & $\mathrm{~N}$ & 0.0 & 0.0 & 0.0 \\
\hline 63R-4, 37-39 & 597.72 & 597.74 & $\mathrm{~N}$ & $\mathrm{~N}$ & 0.0 & 0.0 & 0.0 \\
\hline 73RCC, 33-39 & 695.73 & 695.75 & $\mathrm{~N}$ & $\mathrm{~N}$ & 0.0 & 0.0 & 0.0 \\
\hline 87R-2, 83-85 & 826.24 & 826.26 & $\mathrm{~N}$ & $\mathrm{~N}$ & 0.0 & 0.0 & 0.0 \\
\hline 89R-3, 27-29 & 845.98 & 846.00 & $\mathrm{Y}$ & $\mathrm{Y}$ & 0.1 & 0.0 & 0.0 \\
\hline \multicolumn{8}{|l|}{ Summary } \\
\hline Minimum: & & & & & 0.0 & 0.0 & 0.0 \\
\hline Maximum: & & & & & 0.1 & 0.0 & 0.0 \\
\hline Average: & & & & & 0.0 & 0.0 & 0.0 \\
\hline Standard deviation: & & & & & 0.0 & 0.0 & 0.0 \\
\hline Median: & & & & & 0.0 & 0.0 & 0.0 \\
\hline \multicolumn{8}{|l|}{ Eocene } \\
\hline 95R-CC, 0-2 & 895.50 & 895.52 & $\mathrm{Y}$ & $\mathrm{Y}$ & 468.1 & 138.2 & 310.0 \\
\hline $98 \mathrm{R}-3,71-73$ & 922.95 & 922.97 & $\mathrm{~N}$ & $\mathrm{~N}$ & 0.0 & 0.0 & 0.0 \\
\hline 99R-3, 37-39 & 932.46 & 932.48 & $\mathrm{~N}$ & $\mathrm{~N}$ & 0.0 & 0.0 & 0.0 \\
\hline $101 R-2,57-59$ & 950.87 & 950.89 & $\mathrm{Y}$ & $\mathrm{Y}$ & 294.0 & 118.0 & 86.7 \\
\hline $103 R-1,54-56$ & 968.54 & 968.56 & $\mathrm{~N}$ & $\mathrm{Y}$ & 0.0 & 0.0 & 0.0 \\
\hline $103 R-3,53-55$ & 971.53 & 971.55 & $\mathrm{Y}$ & $\mathrm{Y}$ & 131.9 & 70.1 & 46.7 \\
\hline 104R-2, 64-66 & 979.70 & 979.72 & $\mathrm{~N}$ & $\mathrm{~N}$ & 0.0 & 0.0 & 0.0 \\
\hline 104R-4, 79-81 & 982.81 & 982.83 & $\mathrm{Y}$ & $\mathrm{Y}$ & 225.5 & 89.4 & 80.6 \\
\hline 104R-6, 34-36 & 985.05 & 985.07 & $\mathrm{~N}$ & $\mathrm{Y}$ & 0.0 & 0.0 & 0.0 \\
\hline $105 R-3,53-55$ & 990.64 & 990.66 & $\mathrm{~N}$ & $\mathrm{Y}$ & 0.0 & 0.0 & 0.0 \\
\hline $105 R-4,59-60$ & 992.08 & 992.09 & Y & $\mathrm{Y}$ & 249.7 & 147.8 & 130.7 \\
\hline 106R-2, 82-84 & 998.98 & 999.00 & Y & $\mathrm{Y}$ & 199.6 & 66.9 & 67.7 \\
\hline 106R-CC, 11-13 & & & $\mathrm{Y}$ & $\mathrm{Y}$ & 113.3 & 0.0 & 0.0 \\
\hline \multicolumn{8}{|l|}{ Summary } \\
\hline Minimum: & & & & & 0.0 & 0.0 & 0.0 \\
\hline Maximum: & & & & & 468.1 & 147.8 & 310.0 \\
\hline Average: & & & & & 124.5 & 51.2 & 59.5 \\
\hline Standard deviation: & & & & & 163.0 & 62.4 & 95.1 \\
\hline Median: & & & & & 0.0 & 0.0 & 0.0 \\
\hline
\end{tabular}

Notes: Fraction = N3 (aldehydes and ketones). See "Lipid biomarker analysis" in the "Methods" chapter. SIM = selected ion monitoring. N = no, $\mathrm{Y}=$ yes. GC-MS = gas chromatography-mass spectrometer. 
Table T12. Molecular biomarkers in fraction N4, Site U1356. (See table note.) (Continued on next page.)

\begin{tabular}{|c|c|c|c|c|c|c|c|c|c|c|c|c|c|c|c|c|c|c|c|c|c|c|c|c|}
\hline \multirow{4}{*}{$\begin{array}{l}\text { Core, section, } \\
\text { interval }(\mathrm{cm})\end{array}$} & \multirow{3}{*}{\multicolumn{2}{|c|}{ Depth (mbsf) }} & \multicolumn{22}{|c|}{$n$-alkanols } \\
\hline & & & \multirow{2}{*}{\multicolumn{13}{|c|}{ Compounds [ng/g dry sediment] }} & \multicolumn{3}{|c|}{ Indexes } & \multicolumn{5}{|c|}{ Sterols } & \multirow{3}{*}{$\begin{array}{l}\text { Total } \\
\text { diols }\end{array}$} \\
\hline & & & & & & & & & & & & & & & & \multirow[t]{2}{*}{ 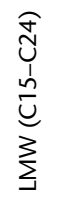 } & \multirow[t]{2}{*}{ 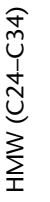 } & \multirow{2}{*}{ 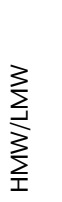 } & \multirow{2}{*}{ 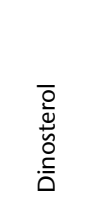 } & \multirow{2}{*}{ 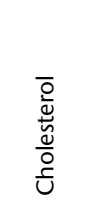 } & \multirow{2}{*}{ 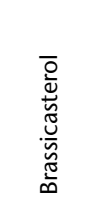 } & \multirow{2}{*}{ 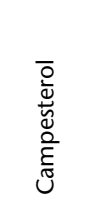 } & \multirow{2}{*}{ 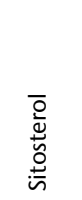 } & \\
\hline & Top & Bottom & $\mathrm{C} 14$ & $\Sigma C 15: n$ & $\Sigma C 16: n$ & $\Sigma C 17: n$ & $\Sigma C 18: n$ & $\Sigma C 19: n$ & $\Sigma C 20: n$ & $\Sigma C 21: n$ & $\Sigma C 22: n$ & $\Sigma C 23: n$ & $\Sigma C 24: n$ & $\mathrm{C} 25$ & $\mathrm{C} 26$ & & & & & & & & & \\
\hline \multicolumn{25}{|l|}{$\begin{array}{l}\text { 318-U1356A- } \\
\text { Miocene }\end{array}$} \\
\hline $2 \mathrm{R}-3,50-51$ & 13.00 & 13.01 & 6 & 5 & 59 & 4 & 67 & 3 & 11 & 5 & 7 & 0 & 0 & 0 & 0 & 166 & 0 & 0.0 & 0 & 50.82 & 0 & 0 & 0 & 0 \\
\hline $15 R-3,83-84$ & 137.63 & 137.64 & 20 & 10 & 120 & 4 & 93 & 11 & 56 & 6 & 66 & 8 & 24 & 0 & 0 & 394 & 24 & 0.1 & 52.59 & 119.9 & 82.6 & 29.57 & 0 & 170.8 \\
\hline $30 \mathrm{R}-3,46-48$ & 280.96 & 280.98 & 0 & 0 & 10 & 0 & 18 & 2 & 13 & 3 & 6 & 0 & 9 & 0 & 0 & 52 & 9 & 0.2 & 0 & 79.01 & 0 & 0 & 0 & 0 \\
\hline $41 \mathrm{R}-3,29-31$ & 386.09 & 386.11 & 4 & 5 & 35 & 4 & 49 & 6 & 31 & 5 & 14 & 3 & 10 & 0 & 0 & 155 & 10 & 0.1 & 0 & 116.8 & 0 & 0 & 0 & 0 \\
\hline $47 \mathrm{R}-3,26-28$ & 443.58 & 443.60 & 0 & 0 & 104 & 21 & 155 & 21 & 72 & 10 & 83 & 0 & 38 & 0 & 0 & 466 & 38 & 0.1 & 161.1 & 382.7 & 268.5 & 121.53 & 146.2 & 448.5 \\
\hline $47 R-4,27-29$ & 444.89 & 444.91 & 5 & 4 & 44 & 2 & 57 & 3 & 16 & 3 & 7 & 0 & 5 & 0 & 0 & 141 & 5 & 0.0 & 0 & 83.51 & 0 & 0 & 0 & 0 \\
\hline \multicolumn{25}{|c|}{ Summary } \\
\hline \multicolumn{3}{|c|}{ Minimum: } & 0 & 0 & 10 & 0 & 18 & 2 & 11 & 3 & 6 & 0 & 0 & 0 & & 52 & 0 & 0.0 & 0.0 & 50.82 & 0 & 0 & 0.0 & 0.0 \\
\hline \multicolumn{3}{|c|}{ Maximum: } & 20 & 10 & 120 & 21 & 155 & 21 & 72 & 10 & 83 & 8 & 38 & 0 & & 466 & 38 & 0.2 & 161.1 & 382.7 & 268.5 & 121.53 & 146.2 & 448.5 \\
\hline \multicolumn{3}{|c|}{ Average: } & 6 & 4 & 62 & 6 & 73 & 8 & 33 & 5 & 30 & 2 & 14 & 0 & & 229 & 14 & 0.1 & 35.6 & 138.8 & 58.52 & 25.18 & 24.4 & 103.2 \\
\hline & Standard & deviation: & 7 & 4 & 42 & 8 & 47 & 7 & 25 & 3 & 35 & 3 & 14 & 0 & & 162 & 14 & 0.1 & 65.0 & 122.2 & 108 & 48.66 & 59.7 & 182.4 \\
\hline & & Median: & 5 & 4 & 51 & 4 & 62 & 5 & 24 & 5 & 10 & 0 & 10 & 0 & & 161 & 10 & 0.1 & 0.0 & 100.2 & 0 & 0 & 0.0 & 0.0 \\
\hline Oligocene & & & & & & & & & & & & & & & & & & & & & & & & \\
\hline 51R-1, 129-131 & 479.89 & 479.91 & 0 & 0 & 0 & 0 & 0 & 0 & 0 & 0 & 0 & 0 & 0 & 0 & 0 & 0 & 0 & & 0 & 0 & 0 & 0 & 0 & 0 \\
\hline 58R-CC, 21-23 & 546.20 & 546.22 & 0 & 0 & 0 & 0 & 0 & 0 & 0 & 0 & 0 & 0 & 0 & 0 & 0 & 0 & 0 & & 0 & 0 & 0 & 0 & 0 & 0 \\
\hline $63 \mathrm{R}-2,25-27$ & 595.03 & 595.05 & 0 & 0 & 0 & 0 & 0 & 0 & 0 & 0 & 0 & 0 & 0 & 0 & 0 & 0 & 0 & & 0 & 0 & 0 & 0 & 0 & 0 \\
\hline $63 R-4,37-39$ & 597.72 & 597.74 & 0 & 0 & 0 & 0 & 0 & 0 & 0 & 0 & 0 & 0 & 0 & 0 & 0 & 0 & 0 & & 0 & 0 & 0 & 0 & 0 & 0 \\
\hline 73R-CC, 37-39 & 695.73 & 695.75 & 2 & 1 & 54 & 39 & 59 & 24 & 25 & 24 & 0 & 0 & 0 & 0 & 0 & 230 & 0 & & 0 & 72.5 & 0 & 0 & 0 & 0 \\
\hline 87R-2, 83-85 & 826.24 & 826.26 & 0 & 1 & 7 & 78 & 6 & 36 & 0 & 0 & 0 & 0 & 0 & 0 & 0 & 128 & 0 & & 0 & 0 & 0 & 0 & 0 & 0 \\
\hline $89 \mathrm{R}-3,27-29$ & 845.98 & 846.00 & 0 & 18 & 112 & 133 & 299 & 32 & 63 & 26 & 0 & 0 & 0 & 0 & 0 & 683 & 0 & & 0 & 160.9 & 0 & 0 & 0 & 0 \\
\hline & & Summary & & & & & & & & & & & & & & & & & & & & & & \\
\hline & & Minimum: & 0 & 0 & 0 & 0 & 0 & 0 & 0 & 0 & 0 & 0 & 0 & 0 & & 0 & 0 & & 0 & 0 & 0 & 0 & 0 & 0 \\
\hline & & haximum: & 2 & 18 & 112 & 133 & 299 & 36 & 63 & 26 & 0 & 0 & 0 & 0 & & 683 & 0 & & 0 & 161 & 0 & 0 & 0 & 0 \\
\hline & & Average: & 0 & 3 & 29 & 42 & 61 & 15 & 15 & 8 & 0 & 0 & 0 & 0 & & 173 & 0 & & 0 & 39 & 0 & 0 & 0 & 0 \\
\hline & Standard & deviation: & 1 & 7 & 43 & 52 & 111 & 17 & 24 & 12 & 0 & 0 & 0 & 0 & & 252 & 0 & & 0 & 62 & 0 & 0 & 0 & 0 \\
\hline & & Median: & 0 & 0 & 0 & 0 & 0 & 0 & 0 & 0 & 0 & 0 & 0 & 0 & & 0 & 0 & & 0 & 0 & 0 & 0 & 0 & 0 \\
\hline
\end{tabular}




\begin{tabular}{|c|c|c|c|c|c|c|c|c|c|c|c|c|c|c|c|c|c|c|c|c|c|c|c|c|}
\hline \multirow{4}{*}{$\begin{array}{l}\text { Core, section, } \\
\text { interval }(\mathrm{cm})\end{array}$} & \multirow{3}{*}{\multicolumn{2}{|c|}{ Depth (mbsf) }} & \multicolumn{22}{|c|}{$n$-alkanols } \\
\hline & & & \multirow{2}{*}{\multicolumn{13}{|c|}{ Compounds [ng/g dry sediment] }} & \multicolumn{3}{|c|}{ Indexes } & \multicolumn{5}{|c|}{ Sterols } & \multirow{3}{*}{$\begin{array}{l}\text { Tota } \\
\text { diols }\end{array}$} \\
\hline & & & & & & & & & & & & & & & & \multirow{2}{*}{ 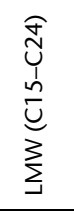 } & \multirow{2}{*}{ 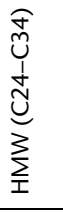 } & \multirow{2}{*}{$\sum_{\sum}^{\sum}$} & \multirow{2}{*}{ 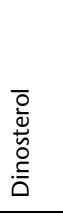 } & \multirow{2}{*}{ 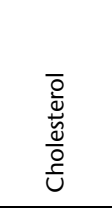 } & \multirow{2}{*}{ 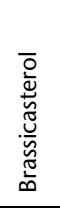 } & \multirow{2}{*}{ 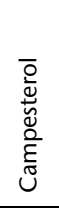 } & \multirow{2}{*}{ 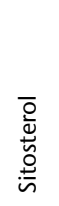 } & \\
\hline & Top & Bottom & C14 & $\Sigma C 15: n$ & $\Sigma C 16: n$ & $\Sigma C 17: n$ & $\Sigma C 18: n$ & $\Sigma C 19: n$ & $\Sigma C 20: n$ & $\Sigma C 21: n$ & $\Sigma \mathrm{C} 22: n$ & $\Sigma C 23: n$ & $\Sigma C 24: n$ & $\mathrm{C} 25$ & $\mathrm{C} 26$ & & & & & & & & & \\
\hline \multicolumn{25}{|l|}{ Eocene } \\
\hline $95 \mathrm{R}-\mathrm{CC}, 0-2$ & 895.50 & 895.52 & 0 & 0 & 190 & 639 & 122 & 203 & 0 & 101 & 0 & 0 & 0 & 0 & 0 & 1254 & 0 & & 0 & 0 & 0 & 0 & 0 & 0 \\
\hline $98 \mathrm{R}-3,71-73$ & 922.95 & 922.97 & 30 & 21 & 295 & 466 & 184 & 732 & 38 & 0 & 0 & 0 & 0 & 0 & 0 & 1766 & 0 & & 0 & 1077 & 0 & 0 & 0 & 0 \\
\hline $99 \mathrm{R}-3,37-39$ & 932.46 & 932.48 & 1 & 28 & 110 & 289 & 46 & 158 & 0 & 0 & 0 & 0 & 0 & 0 & 0 & 632 & 0 & & 0 & 49.18 & 0 & 0 & 0 & 0 \\
\hline $101 \mathrm{R}-2,57-59$ & 950.87 & 950.89 & 89 & 64 & 542 & 243 & 257 & 333 & 302 & 38 & 16 & 0 & 0 & 0 & 0 & 1883 & 0 & & 0 & 0 & 0 & 0 & 0 & 0 \\
\hline $103 R-1,54-56$ & 968.54 & 968.56 & 0 & 40 & 66 & 212 & 59 & 187 & 0 & 14 & 4 & 2 & 2 & 0 & 0 & 583 & 2 & 0.0 & 0 & 25.48 & 0 & 0 & 0 & 0 \\
\hline $103 R-3,53-55$ & 971.53 & 971.55 & 101 & 131 & 1204 & 761 & 629 & 309 & 278 & 34 & 0 & 19 & 0 & 0 & 0 & 3465 & 0 & & 0 & 198.3 & 0 & 0 & 0 & 0 \\
\hline $104 \mathrm{R}-2,64-66$ & 979.70 & 979.72 & 0 & 4 & 117 & 470 & 51 & 214 & 28 & 27 & 0 & 0 & 0 & 0 & 0 & 912 & 0 & & 0 & 0 & 0 & 0 & 0 & 0 \\
\hline 104R-4, 79-81 & 982.81 & 982.83 & 50 & 117 & 854 & 432 & 858 & 336 & 138 & 73 & 9 & 8 & 0 & 0 & 0 & 2876 & 0 & & 0 & 162.1 & 0 & 0 & 0 & 0 \\
\hline $104 \mathrm{R}-6,34-36$ & 985.05 & 985.07 & 0 & 5 & 6 & 40 & 31 & 15 & 20 & 0 & 0 & 0 & 0 & 0 & 0 & 116 & 0 & & 0 & 0 & 0 & 0 & 0 & 0 \\
\hline $105 R-3,53-55$ & 990.64 & 990.66 & 6 & 41 & 79 & 310 & 75 & 215 & 0 & 4 & 0 & 0 & 0 & 0 & 0 & 729 & 0 & & 0 & 0 & 0 & 0 & 0 & 0 \\
\hline $105 R-4,59-60$ & 992.08 & 992.09 & 23 & 85 & 209 & 379 & 389 & 89 & 48 & 14 & 0 & 0 & 0 & 0 & 0 & 1236 & 0 & & 0 & 232.2 & 0 & 0 & 0 & 0 \\
\hline 106R-2, 82-84 & 998.98 & 999.00 & 36 & 228 & 470 & 827 & 474 & 592 & 122 & 75 & 20 & 0 & 0 & 0 & 0 & 2845 & 0 & & 0 & 453 & 0 & 0 & 0 & 0 \\
\hline 106R-CC, 11-13 & 999.98 & 1000.00 & 93 & 127 & 634 & 382 & 412 & 243 & 341 & 128 & 25 & 42 & 20 & 0 & 0 & 2425 & 20 & 0.0 & 0 & 230.3 & 0 & 0 & 0 & 0 \\
\hline \multicolumn{25}{|c|}{ Summary } \\
\hline \multicolumn{3}{|c|}{ Minimum: } & 0 & 0 & 6 & 40 & 31 & 15 & 0 & 0 & 0 & 0 & 0 & 0 & 0 & 116 & 0 & 0 & 0 & 0 & 0 & 0 & 0 & 0 \\
\hline \multirow{2}{*}{\multicolumn{3}{|c|}{ Maximum: }} & 101 & 228 & 1204 & 827 & 858 & 732 & 341 & 128 & 25 & 42 & 20 & 0 & 0 & 3465 & 20 & 0 & 0 & 1077 & 0 & 0 & 0 & 0 \\
\hline & & & 33 & 68 & 368 & 419 & 276 & 279 & 101 & 39 & 6 & 5 & 2 & 0 & 0 & 1594 & 2 & 0 & 0 & 187 & 0 & 0 & 0 & 0 \\
\hline \multicolumn{3}{|c|}{$\begin{array}{r}\text { Average: } \\
\text { Standard deviation: }\end{array}$} & 39 & 67 & 359 & 221 & 261 & 195 & 126 & 42 & 9 & 12 & 5 & 0 & 0 & 1045 & 5 & 0 & 0 & 301 & 0 & 0 & 0 & 0 \\
\hline \multicolumn{3}{|r|}{ Median: } & 23 & 41 & 209 & 382 & 184 & 215 & 38 & 27 & 0 & 0 & 0 & 0 & 0 & 1254 & 0 & 0 & 0 & 49 & 0 & 0 & 0 & 0 \\
\hline
\end{tabular}

Note: Fraction = N4 (alcohols). See "Lipid biomarker analysis" in the "Methods" chapter. LMW = low molecular weight, HMW = high molecular weight. 
Table T13. Molecular biomarkers in fraction FAMES, Site U1356. (See table note.) (Continued on next page.)

\begin{tabular}{|c|c|c|c|c|c|c|c|c|c|c|c|c|c|c|c|c|c|c|c|c|c|c|c|c|}
\hline \multirow{4}{*}{$\begin{array}{l}\text { Core, section, } \\
\text { interval }(\mathrm{cm})\end{array}$} & \multirow{3}{*}{\multicolumn{2}{|c|}{ Depth (mbsf) }} & \multicolumn{22}{|c|}{$n$-alkanoic acids } \\
\hline & & & \multirow{2}{*}{\multicolumn{18}{|c|}{ Compounds [ng/g dry sediment] }} & \multicolumn{4}{|c|}{ Indexes } \\
\hline & & & & & & & & & & & & & & & & & & & & & \multirow{2}{*}{ 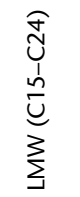 } & \multirow{2}{*}{ 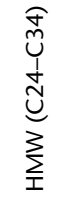 } & \multirow{2}{*}{ 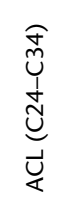 } & \multirow{2}{*}{$\sum_{\sum_{I}}^{3}$} \\
\hline & Top & Bottom & C14 & $\Sigma C 15: n$ & $\mathrm{C} 16$ & $\Sigma C 17: n$ & $\Sigma C 18: n$ & C19 & $\mathrm{C} 20$ & $\mathrm{C} 21$ & $\mathrm{C} 22$ & $\mathrm{C} 23$ & C24 & C25 & $\mathrm{C} 26$ & C27 & $\mathrm{C} 28$ & C29 & $\mathrm{C} 30$ & $\mathrm{C} 31$ & & & & \\
\hline \multicolumn{25}{|l|}{$\begin{array}{l}\text { 318-U1356A- } \\
\text { Miocene }\end{array}$} \\
\hline $2 \mathrm{R}-3,50-51$ & 13.00 & 13.01 & 3 & 3 & 91 & 8 & 144 & 0 & 10 & 0 & 25 & 0 & 6 & 0 & 0 & 0 & 0 & 0 & 0 & 0 & 597 & 13 & 24.0 & 0.0 \\
\hline $15 R-3,83-84$ & 137.63 & 137.64 & 0 & 0 & 81 & 8 & 82 & 0 & 23 & 0 & 65 & 0 & 52 & 0 & 23 & 0 & 0 & 0 & 0 & 0 & 540 & 151 & 24.6 & 0.3 \\
\hline $30 \mathrm{R}-3,46-48$ & 280.96 & 280.98 & 78 & 44 & 372 & 24 & 224 & 6 & 10 & 0 & 10 & 0 & 7 & 0 & 0 & 0 & 0 & 0 & 0 & 0 & 1624 & 15 & 24.0 & 0.0 \\
\hline $41 \mathrm{R}-3,29-31$ & 386.09 & 386.11 & 0 & 0 & 89 & 0 & 87 & 0 & 0 & 0 & 0 & 0 & 0 & 0 & 0 & 0 & 0 & 0 & 0 & 0 & 373 & 0 & & 0.0 \\
\hline $47 \mathrm{R}-3,26-28$ & 443.58 & 443.60 & 78 & 40 & 359 & 19 & 192 & 0 & 40 & 0 & 181 & 0 & 127 & 0 & 0 & 0 & 0 & 0 & 0 & 0 & 1904 & 258 & 24.0 & 0.1 \\
\hline \multirow[t]{7}{*}{$47 \mathrm{R}-4,27-29$} & 444.89 & 444.91 & 3 & 3 & 40 & 3 & 71 & 0 & 3 & 0 & 23 & 0 & 0 & 0 & 0 & 0 & 0 & 0 & 0 & 0 & 311 & 0 & & 0.0 \\
\hline & \multicolumn{2}{|c|}{ Summary } & & & & & & & & & & & & & & & & & & & & & & \\
\hline & \multicolumn{2}{|r|}{ Minimum: } & 0 & 0 & 40 & 0 & 71 & 0 & 0 & 0 & 0 & 0 & 0 & 0 & 0 & 0 & 0 & 0 & 0 & 0 & 311 & 0 & 24.0 & 0.0 \\
\hline & \multicolumn{2}{|r|}{ Maximum: } & 78 & 44 & 372 & 24 & 224 & 6 & 40 & 0 & 181 & 0 & 127 & 0 & 23 & 0 & 0 & 0 & 0 & 0 & 1904 & 258 & 24.6 & 0.3 \\
\hline & \multicolumn{2}{|c|}{ Average: } & 27 & 15 & 172 & 10 & 133 & 1 & 14 & 0 & 51 & 0 & 32 & 0 & 4 & 0 & 0 & 0 & 0 & 0 & 892 & 73 & 24.2 & 0.1 \\
\hline & \multirow{2}{*}{\multicolumn{2}{|c|}{$\begin{array}{r}\text { Standard deviation: } \\
\text { Median: }\end{array}$}} & 39 & 21 & 151 & 9 & 64 & 2 & 15 & 0 & 67 & 0 & 50 & 0 & 9 & 0 & 0 & 0 & 0 & 0 & 689 & 108 & 0.3 & 0.1 \\
\hline & & & 3 & 3 & 90 & 8 & 115 & 0 & 10 & 0 & 24 & 0 & 7 & 0 & 0 & 0 & 0 & 0 & 0 & 0 & 569 & 14 & 24.0 & 0.0 \\
\hline \multicolumn{25}{|l|}{ Oligocene } \\
\hline 51R-1, 129-131 & 479.89 & 479.91 & 0 & 1 & 62 & 0 & 107 & 0 & 16 & 0 & 36 & 0 & 0 & 0 & 0 & 0 & 0 & 0 & 0 & 0 & 934 & 0 & & 0.0 \\
\hline $58 \mathrm{R}-\mathrm{CC}, 21-23$ & 546.20 & 546.22 & 0 & 0 & 11 & 4 & 7 & 0 & 0 & 0 & 0 & 0 & 0 & 0 & 0 & 0 & 0 & 0 & 0 & 0 & 100 & 0 & & 0.0 \\
\hline $63 \mathrm{R}-2,25-27$ & 595.03 & 595.05 & 3 & 8 & 86 & 25 & 218 & 6 & 8 & 0 & 24 & 0 & 17 & 0 & 13 & 0 & 0 & 0 & 0 & 0 & 1644 & 102 & 24.9 & 0.1 \\
\hline $63 R-4,37-39$ & 597.72 & 597.74 & 0 & 2 & 104 & 22 & 226 & 0 & 12 & 0 & 87 & 0 & 70 & 0 & 78 & 0 & 51 & 0 & 0 & 0 & 808 & 306 & 25.5 & 0.4 \\
\hline 73R-CC, 33-39 & 695.73 & 695.75 & 1 & 4 & 152 & 17 & 187 & 0 & 0 & 0 & 0 & 0 & 0 & 0 & 0 & 0 & 0 & 0 & 0 & 0 & 1612 & 0 & & 0.0 \\
\hline $87 R-2,83-85$ & 826.24 & 826.26 & 2 & 10 & 192 & 30 & 329 & 15 & 34 & 0 & 112 & 0 & 55 & 0 & 20 & 0 & 21 & 0 & 0 & 0 & 1290 & 151 & 25.0 & 0.1 \\
\hline $89 R-3,27-29$ & 845.98 & 846.00 & 3 & 13 & 199 & 28 & 446 & 0 & 35 & 0 & 0 & 0 & 243 & 34 & 314 & 0 & 157 & 0 & 0 & 0 & 1164 & 1855 & 25.4 & 1.6 \\
\hline \multicolumn{25}{|c|}{ Summary } \\
\hline \multicolumn{3}{|r|}{ Minimum: } & 0 & 0 & 11 & 0 & 7 & 0 & 0 & 0 & 0 & 0 & 0 & 0 & 0 & 0 & 0 & 0 & 0 & 0 & 100 & 0 & 24.9 & 0.0 \\
\hline \multirow{2}{*}{\multicolumn{3}{|c|}{ Maximum: }} & 3 & 13 & 199 & 30 & 446 & 15 & 35 & 0 & 112 & 0 & 243 & 34 & 314 & 0 & 157 & 0 & 0 & 0 & 1644 & 1855 & 25.5 & 1.6 \\
\hline & & & 1 & 7 & 124 & 21 & 236 & 4 & 15 & 0 & 37 & 0 & 64 & 6 & 71 & 0 & 38 & 0 & 0 & 0 & 1103 & 402 & 25.2 & 0.4 \\
\hline & Standard & deviation: & 1 & 5 & 70 & 12 & 143 & 6 & 14 & 0 & 46 & 0 & 88 & 13 & 115 & 0 & 58 & 0 & 0 & 0 & 533 & 675 & 0.3 & 0.6 \\
\hline & & Median: & 1 & 4 & 104 & 22 & 218 & 0 & 12 & 0 & 24 & 0 & 17 & 0 & 13 & 0 & 0 & 0 & 0 & 0 & 1164 & 102 & 25.2 & 0.1 \\
\hline
\end{tabular}


Table T13 (continued).

\begin{tabular}{|c|c|c|c|c|c|c|c|c|c|c|c|c|c|c|c|c|c|c|c|c|c|c|c|c|}
\hline \multirow{4}{*}{$\begin{array}{l}\text { Core, section, } \\
\text { interval }(\mathrm{cm})\end{array}$} & \multirow{3}{*}{\multicolumn{2}{|c|}{ Depth (mbsf) }} & \multicolumn{22}{|c|}{$n$-alkanoic acids } \\
\hline & & & \multirow{2}{*}{\multicolumn{18}{|c|}{ Compounds [ng/g dry sediment] }} & \multicolumn{4}{|c|}{ Indexes } \\
\hline & & & & & & & & & & & & & & & & & & & & & \multirow{2}{*}{ 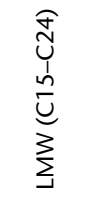 } & \multirow{2}{*}{ 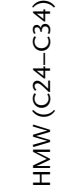 } & \multirow{2}{*}{ 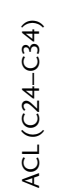 } & \multirow{2}{*}{ 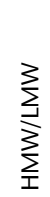 } \\
\hline & Top & Bottom & $\mathrm{C} 14$ & $\Sigma C 15: n$ & $\mathrm{C} 16$ & $\Sigma C 17: n$ & $\Sigma C 18: n$ & C19 & $\mathrm{C} 20$ & $\mathrm{C} 21$ & $\mathrm{C} 22$ & $\mathrm{C} 23$ & $\mathrm{C} 24$ & $\mathrm{C} 25$ & $\mathrm{C} 26$ & $\mathrm{C} 27$ & $\mathrm{C} 28$ & $\mathrm{C} 29$ & $\mathrm{C} 30$ & C31 & & & & \\
\hline \multicolumn{25}{|l|}{ Eocene } \\
\hline 95R-CC, $0-2$ & 895.50 & 895.52 & 0 & 0 & 0 & 0 & 0 & 0 & 0 & 0 & 52 & 0 & 43 & 0 & 22 & 0 & 45 & 0 & 0 & 0 & 150 & 234 & 25.3 & 1.6 \\
\hline $98 \mathrm{R}-3,71-73$ & 922.95 & 922.97 & 213 & 191 & 1641 & 118 & 1373 & 0 & 11 & 0 & 0 & 0 & 17 & 0 & 0 & 0 & 0 & 0 & 0 & 0 & 5492 & 48 & 24.0 & 0.0 \\
\hline $99 \mathrm{R}-3,37-39$ & 932.46 & 932.48 & 8 & 9 & 227 & 9 & 108 & 0 & 0 & 0 & 36 & 0 & 0 & 0 & 0 & 0 & 0 & 0 & 0 & 0 & 662 & 0 & & 0.0 \\
\hline $101 \mathrm{R}-2,57-59$ & 950.87 & 950.89 & 445 & 394 & 2070 & 327 & 1910 & 296 & 269 & 232 & 984 & 192 & 404 & 119 & 289 & 255 & 742 & 0 & 473 & 0 & 13611 & 3800 & 26.3 & 0.3 \\
\hline $103 \mathrm{R}-1,54-56$ & 968.54 & 968.56 & 11 & 13 & 64 & 0 & 139 & 2 & 0 & 2 & 0 & 0 & 2 & 0 & 0 & 0 & 0 & 0 & 0 & 0 & 361 & 6 & 24.0 & 0.0 \\
\hline $103 \mathrm{R}-3,53-55$ & 971.53 & 971.55 & & 512 & 3340 & 242 & 2192 & 36 & 102 & 110 & 0 & 141 & 146 & 0 & 0 & 205 & 455 & 0 & 0 & 0 & 11364 & 1078 & 26.3 & 0.1 \\
\hline $104 \mathrm{R}-2,64-66$ & 979.70 & 979.72 & 0 & 0 & 0 & 0 & 0 & 0 & 0 & 0 & 0 & 0 & 0 & 0 & 0 & 0 & 0 & 0 & 0 & 0 & 0 & 0 & & \\
\hline 104R-4, 79-81 & 982.81 & 982.83 & 400 & 866 & 3666 & 462 & 2481 & 164 & 287 & 326 & 801 & 344 & 229 & 178 & 462 & 236 & 336 & 0 & 0 & 0 & 17676 & 3067 & 25.7 & 0.2 \\
\hline $104 R-6,34-36$ & 985.05 & 985.07 & 8 & 8 & 88 & 15 & 156 & 18 & 27 & 21 & 39 & 22 & 45 & 19 & 49 & 30 & 176 & 51 & 82 & 0 & 1798 & 828 & 26.5 & 0.5 \\
\hline $105 R-3,53-55$ & 990.64 & 990.66 & 57 & 55 & 534 & 0 & 0 & 25 & 24 & 23 & 71 & 18 & 64 & 23 & 182 & 30 & 140 & 0 & 61 & 0 & 1460 & 1003 & 26.1 & 0.7 \\
\hline $105 \mathrm{R}-4,59-60$ & 992.08 & 992.09 & 297 & 311 & 2080 & 363 & 1676 & 114 & 184 & 159 & 888 & 91 & 359 & 0 & 669 & 0 & 453 & 0 & 501 & 0 & 11416 & 3905 & 26.2 & 0.3 \\
\hline $106 \mathrm{R}-2,82-84$ & 998.98 & 999.00 & 16 & 106 & 2253 & 349 & 3023 & 136 & 158 & 99 & 1162 & 156 & 308 & 107 & 268 & 309 & 983 & 0 & 529 & 163 & 13790 & 3942 & 26.8 & 0.3 \\
\hline 106R-CC, 11-13 & 999.98 & 1000.00 & 0 & 0 & 380 & 91 & 714 & 108 & 150 & 111 & 677 & 68 & 226 & 107 & 0 & 0 & 486 & 0 & 155 & 0 & 5030 & 1597 & 26.0 & 0.3 \\
\hline \multicolumn{25}{|c|}{ Summary } \\
\hline \multicolumn{3}{|r|}{ Minimum: } & 0 & 0 & 0 & 0 & 0 & 0 & 0 & 0 & 0 & 0 & 0 & 0 & 0 & 0 & 0 & 0 & 0 & 0 & 0 & 0 & 24.0 & 0.0 \\
\hline \multirow{2}{*}{\multicolumn{3}{|c|}{ Maximum: }} & 445 & 866 & 3666 & 462 & 3023 & 296 & 287 & 326 & 1162 & 344 & 404 & 178 & 669 & 309 & 983 & 51 & 529 & 163 & 17676 & 3942 & 26.8 & 1.6 \\
\hline & & & 121 & 190 & 1257 & 152 & 1059 & 69 & 93 & 83 & 362 & 79 & 142 & 43 & 149 & 82 & 294 & 4 & 138 & 13 & 6370 & 1501 & 25.7 & 0.4 \\
\hline \multicolumn{3}{|c|}{ Standard deviation: } & 170 & 266 & 1321 & 172 & 1096 & 90 & 106 & 104 & 458 & 105 & 147 & 62 & 216 & 120 & 318 & 14 & 212 & 45 & 6333 & 1603 & 0.9 & 0.4 \\
\hline \multicolumn{3}{|r|}{ Median: } & 13 & 55 & 534 & 91 & 714 & 25 & 27 & 23 & 52 & 22 & 64 & 0 & 22 & 0 & 176 & 0 & 0 & 0 & 5030 & 1003 & 26.1 & 0.3 \\
\hline
\end{tabular}

Note: Fraction = FAMES (fatty acid methyl esters). See "Lipid biomarker analysis" in the "Methods" chapter. LMW = low molecular weight, HMW = high molecular weight, ACL = average chain length, $\mathrm{CPI}=$ carbon preference index. 
Table T14. Major and trace element concentrations, Site U1356. (See table notes.) (Continued on next page.)

\begin{tabular}{|c|c|c|c|c|c|c|c|c|c|c|c|c|c|c|c|c|}
\hline \multirow{2}{*}{$\begin{array}{l}\text { Core, section, } \\
\text { interval }(\mathrm{cm})\end{array}$} & \multirow{2}{*}{$\begin{array}{l}\text { Depth } \\
\text { (mbsf) }\end{array}$} & \multicolumn{9}{|c|}{ Major element oxide (wt\%) } & \multicolumn{5}{|c|}{ Trace element (ppm) } & \multirow[b]{2}{*}{$\mathrm{ClA}$} \\
\hline & & $\mathrm{SiO}_{2}$ & $\mathrm{TiO}_{2}$ & $\mathrm{Al}_{2} \mathrm{O}_{3}$ & $\mathrm{Fe}_{2} \mathrm{O}_{3}$ & $\mathrm{MgO}$ & $\mathrm{CaO}$ & $\mathrm{Na}_{2} \mathrm{O}$ & $\mathrm{K}_{2} \mathrm{O}$ & $\mathrm{P}_{2} \mathrm{O}_{5}$ & $\mathrm{Ba}$ & $\mathrm{Sr}$ & V & Sc & Co & \\
\hline \multicolumn{17}{|l|}{ 318-U1356A- } \\
\hline $1 \mathrm{R}-2,49-51$ & 1.99 & 75.76 & 0.60 & 10.50 & 3.91 & 1.91 & 1.92 & 2.70 & 2.53 & 0.12 & 645 & 140 & 57 & 10 & 7 & NA \\
\hline $1 \mathrm{R}-3,13-15$ & 3.13 & 78.80 & 0.46 & 9.92 & 3.29 & 1.56 & 0.92 & 2.30 & 2.57 & 0.13 & 476 & 110 & 60 & 11 & 7 & NA \\
\hline $2 \mathrm{R}-6,57-58$ & 17.58 & 71.49 & 0.59 & 12.39 & 5.38 & 2.46 & 1.13 & 3.12 & 3.27 & 0.11 & 589 & 116 & 78 & 13 & 10 & 54 \\
\hline $3 \mathrm{R}-\mathrm{CC}, 6-7$ & 19.63 & 71.11 & 0.64 & 12.30 & 5.51 & 2.48 & 1.44 & 3.06 & 3.30 & 0.10 & 650 & 139 & 118 & 12 & 8 & 53 \\
\hline $11 \mathrm{R}-2,84-85$ & 97.74 & 67.83 & 0.70 & 14.10 & 5.49 & 2.73 & 2.50 & 2.98 & 3.42 & 0.14 & 470 & 150 & 116 & 18 & 12 & 53 \\
\hline $12 \mathrm{R}-2,70-71$ & 107.10 & 72.19 & 0.62 & 12.28 & 4.46 & 2.16 & 1.73 & 3.16 & 3.22 & 0.11 & 428 & 153 & 92 & 11 & 9 & 51 \\
\hline $13 R-1,57-58$ & 115.07 & 74.86 & 0.62 & 11.62 & 3.42 & 2.00 & 1.47 & 2.83 & 2.99 & 0.13 & 388 & 129 & 83 & 10 & 9 & 53 \\
\hline $14 \mathrm{R}-2,132-133$ & 126.92 & 70.40 & 0.66 & 12.98 & 5.42 & 2.50 & 1.60 & 2.96 & 3.29 & 0.12 & 456 & 137 & 108 & 14 & 9 & 54 \\
\hline $15 \mathrm{R}-\mathrm{CC}, 6-7$ & 141.59 & 73.22 & 0.59 & 11.60 & 4.54 & 2.24 & 1.52 & 3.04 & 3.05 & 0.13 & 498 & 136 & 93 & 12 & 8 & 51 \\
\hline $17 \mathrm{R}-2,3-5$ & 154.53 & 72.11 & 0.60 & 11.96 & 5.35 & 2.25 & 1.71 & 2.90 & 2.90 & 0.13 & 513 & 138 & 105 & 12 & 8 & 52 \\
\hline $17 R-4,110-112$ & 158.60 & 73.24 & 0.63 & 11.94 & 4.51 & 2.28 & 1.49 & 2.97 & 2.77 & 0.11 & 485 & 137 & 106 & 13 & 10 & 52 \\
\hline $18 \mathrm{R}-2,80-81$ & 164.80 & 71.96 & 0.63 & 12.71 & 4.44 & 2.33 & 1.82 & 2.91 & 2.97 & 0.13 & 549 & 150 & 101 & 14 & 11 & 53 \\
\hline $19 R-5,123-124$ & 179.34 & 71.02 & 0.67 & 12.68 & 5.33 & 2.36 & 1.86 & 3.05 & 2.82 & 0.13 & 449 & 162 & 103 & 13 & 7 & 52 \\
\hline 20R-2, 75-76 & 183.95 & 68.09 & 0.70 & 14.18 & 5.32 & 2.90 & 2.05 & 3.07 & 3.41 & 0.16 & 586 & 152 & 111 & 16 & 13 & 54 \\
\hline $21 \mathrm{R}-2,39-40$ & 193.19 & 68.81 & 0.72 & 13.91 & 5.42 & 2.57 & 2.04 & 2.99 & 3.29 & 0.15 & 573 & 162 & 110 & 13 & 17 & 54 \\
\hline $22 \mathrm{R}-1,48.5-49.5$ & 201.39 & 72.56 & 0.59 & 12.20 & 5.09 & 2.13 & 1.46 & 2.98 & 2.80 & 0.12 & 449 & 146 & 96 & 12 & 14 & 53 \\
\hline $22 \mathrm{R}-2,41-42$ & 202.81 & 70.71 & 0.66 & 13.14 & 4.71 & 2.49 & 2.16 & 2.86 & 3.00 & 0.14 & 548 & 155 & 113 & 15 & 10 & 53 \\
\hline $23 \mathrm{R}-1,50.5-51.5$ & 211.01 & 70.01 & 0.67 & 13.42 & 5.20 & 2.53 & 2.05 & 2.74 & 3.01 & 0.14 & 510 & 145 & 110 & 14 & 10 & 54 \\
\hline 24R-1, 88-89 & 220.98 & 68.26 & 0.69 & 14.14 & 5.38 & 2.69 & 2.00 & 3.23 & 3.36 & 0.15 & 587 & 158 & 111 & 16 & 8 & 53 \\
\hline $30 \mathrm{R}-1,47-48$ & 277.97 & 67.80 & 0.74 & 14.47 & 6.03 & 2.71 & 1.96 & 2.64 & 3.40 & 0.13 & 874 & 141 & 116 & 17 & 10 & 57 \\
\hline $33 \mathrm{R}-1,83.5-84.5$ & 307.24 & 72.56 & 0.59 & 12.67 & 4.18 & 2.26 & 1.48 & 2.76 & 3.29 & 0.12 & 716 & 136 & 90 & 11 & 8 & 55 \\
\hline $34 R-4,68-69$ & 320.58 & 71.67 & 0.67 & 12.79 & 4.80 & 2.30 & 1.89 & 2.66 & 2.93 & 0.14 & 696 & 142 & 105 & 14 & 9 & 54 \\
\hline $35 R-4,113-114$ & 331.13 & 69.23 & 0.73 & 13.98 & 5.52 & 2.42 & 2.01 & 2.70 & 3.16 & 0.15 & 891 & 174 & 133 & 18 & 9 & NA \\
\hline 39R-1, 67-68 & 364.27 & 71.98 & 0.62 & 12.97 & 5.00 & 2.34 & 1.50 & 2.30 & 3.09 & 0.11 & 801 & 128 & 111 & 16 & 17 & NA \\
\hline $39 \mathrm{R}-2,60-61$ & 365.69 & 68.19 & 0.76 & 13.96 & 6.25 & 2.73 & 1.86 & 2.73 & 3.26 & 0.12 & 761 & 160 & 116 & 16 & 8 & 56 \\
\hline 40R-2, 13-14 & 374.83 & 68.34 & 0.75 & 14.15 & 6.41 & 2.72 & 1.64 & 2.46 & 3.33 & 0.11 & 785 & 138 & 116 & 17 & 11 & 59 \\
\hline $41 \mathrm{R}-2,32-34$ & 384.62 & 66.47 & 0.77 & 15.02 & 6.40 & 2.92 & 1.87 & 2.72 & 3.56 & 0.13 & 914 & 151 & 125 & 18 & 14 & 58 \\
\hline $42 \mathrm{R}-1,106-107$ & 393.46 & 68.78 & 0.74 & 13.83 & 5.92 & 2.56 & 1.83 & 2.56 & 3.52 & 0.15 & 638 & 150 & 107 & 16 & 9 & 57 \\
\hline $43 \mathrm{R}-2,7-8$ & 403.57 & 69.47 & 0.70 & 13.23 & 5.67 & 2.54 & 2.67 & 2.35 & 3.11 & 0.14 & 678 & 170 & 109 & 14 & 10 & 54 \\
\hline $44 \mathrm{R}-1,56-57$ & 412.16 & 68.17 & 0.78 & 14.07 & 5.97 & 2.79 & 1.99 & 2.55 & 3.43 & 0. & 742 & 166 & 133 & 16 & 19 & 57 \\
\hline $45 \mathrm{R}-1,75-76$ & 421.95 & 68.51 & 0.68 & 14.01 & 5.66 & 2.56 & 2.12 & 2.56 & 3.62 & 0.1 & 768 & 162 & 118 & 14 & 12 & 56 \\
\hline $46 \mathrm{R}-2,105-106$ & 433.29 & 66.70 & 0.77 & 14.00 & 6.28 & 2.75 & 3.42 & 2.50 & 3.31 & 0.15 & 746 & 210 & 118 & 17 & 16 & 58 \\
\hline $47 \mathrm{R}-2,64-66$ & 442.50 & 65.71 & 0.79 & 15.08 & 6.57 & 2.83 & 2.82 & 2.37 & 3.59 & 0.13 & 780 & 177 & 122 & 17 & 21 & NA \\
\hline $47 R-4,61-63$ & 445.23 & 62.73 & 0.61 & 11.35 & 5.05 & 2.44 & 12.46 & 2.09 & 2.85 & 0.14 & 433 & 421 & 84 & 12 & 10 & NA \\
\hline $48 \mathrm{R}-1,84-85$ & 450.74 & 66.28 & 0.73 & 13.78 & 6.10 & 2.79 & 4.56 & 2.27 & 3.14 & 0 & 930 & 224 & 118 & 17 & 17 & 59 \\
\hline 49R-CC, 11-13 & 460.02 & 71.46 & 0.58 & 13.29 & 4.44 & 2.11 & 1.94 & 2.53 & 3.41 & 0.14 & 852 & 183 & 109 & 11 & 13 & 56 \\
\hline $51 \mathrm{R}-1,59-61$ & 479.18 & 79.22 & 0.37 & 9.99 & 2.71 & 1.15 & 1.83 & 2.21 & 2.37 & 0.08 & 522 & 157 & 49 & 8 & 9 & 52 \\
\hline $51 \mathrm{R}-2,40-41$ & 480.50 & 72.00 & 0.65 & 12.53 & 5.69 & 2.36 & 1.50 & 2.14 & 2.93 & 0.12 & 546 & 134 & 111 & 14 & 16 & 59 \\
\hline $53 \mathrm{R}-1,131-132$ & 499.11 & 68.57 & 0.71 & 14.28 & 5.89 & 2.67 & 2.01 & 2.21 & 3.42 & 0.15 & 617 & 138 & 125 & 19 & 16 & NA \\
\hline 54R-1, 6-7 & 507.46 & 69.11 & 0.65 & 13.54 & 5.90 & 2.45 & 2.55 & 2.31 & 3.22 & 0.15 & 583 & 179 & 111 & 12 & 19 & 55 \\
\hline $54 \mathrm{R}-3,43-44$ & 510.52 & 64.50 & 0.76 & 14.62 & 9.47 & 2.96 & 1.62 & 2.29 & 3.52 & 0.16 & 691 & 158 & 141 & 17 & 24 & 61 \\
\hline 57R-1, 83-84 & 536.63 & 67.73 & 0.81 & 14.29 & 6.40 & 2.70 & 1.97 & 2.59 & 3.25 & 0.16 & 556 & 188 & 124 & 15 & 11 & 57 \\
\hline $58 \mathrm{R}-1,26-27$ & 545.66 & 72.37 & 0.65 & 12.07 & 5.11 & 2.49 & 2.13 & 2.13 & 2.82 & 0.13 & 451 & 152 & 105 & 14 & 12 & 55 \\
\hline $59 \mathrm{R}-1,20-21$ & 555.20 & 70.53 & 0.62 & 13.43 & 5.19 & 2.36 & 2.07 & 2.32 & 3.19 & 0.16 & 606 & 187 & 111 & 16 & 22 & 57 \\
\hline $60 R-1,33-35$ & 564.93 & 74.68 & 0.56 & 11.69 & 4.45 & 2.18 & 1.29 & 1.80 & 3.11 & 0.1 & 457 & 107 & 87 & 13 & 11 & NA \\
\hline $60 \mathrm{R}-1,88-89$ & 565.48 & 76.64 & 0.51 & 10.40 & 4.21 & 2.11 & 1.12 & 1.90 & 2.86 & 0.18 & 421 & 111 & 101 & 10 & 14 & 59 \\
\hline 63R-2, 16-17 & 594.95 & 65.98 & 0.70 & 14.67 & 7.19 & 3.45 & 1.50 & 2.32 & 3.95 & 0.14 & 684 & 177 & 121 & 20 & 19 & NA \\
\hline $64 \mathrm{R}-2,9-11$ & 604.60 & 68.04 & 0.68 & 14.18 & 6.15 & 2.92 & 1.65 & 2.37 & 3.74 & 0.16 & 633 & 162 & 138 & 22 & 14 & 60 \\
\hline $66 \mathrm{R}-1,41-42$ & 622.70 & 65.59 & 0.80 & 15.48 & 7.29 & 3.12 & 1.44 & 2.36 & 3.69 & 0.12 & 973 & 246 & 158 & 21 & 18 & 63 \\
\hline 67R-1, 74-75 & 632.64 & 68.97 & 0.78 & 14.44 & 5.87 & 2.65 & 1.28 & 2.20 & 3.58 & 0.14 & 637 & 153 & 135 & 17 & 7 & 63 \\
\hline $68 \mathrm{R}-3,27-28$ & 644.54 & 68.73 & 0.72 & 14.58 & 5.69 & 2.76 & 1.06 & 2.20 & 4.00 & 0.16 & 643 & 142 & 128 & 19 & 11 & 65 \\
\hline $68 R-5,4-5$ & 647.07 & 73.99 & 0.62 & 12.04 & 4.49 & 2.15 & 1.32 & 2.25 & 2.92 & 0.14 & 466 & 145 & 85 & 15 & 14 & 59 \\
\hline $69 \mathrm{R}-3,62-63$ & 654.28 & 69.68 & 0.76 & 13.09 & 6.29 & 2.80 & 1.63 & 2.31 & 3.04 & 0.30 & 517 & 158 & 97 & 15 & 18 & 59 \\
\hline $69 R-4,63-64$ & 655.73 & 68.60 & 0.71 & 14.67 & 6.06 & 2.89 & 0.97 & 2.13 & 3.73 & 0.13 & 628 & 136 & 126 & 17 & 16 & 66 \\
\hline 70R-2, 18-19 & 662.23 & 69.25 & 0.71 & 14.18 & 5.97 & 2.73 & 1.18 & 2.15 & 3.59 & 0.14 & 698 & 149 & 124 & 18 & 18 & 64 \\
\hline $71 \mathrm{R}-5,95-97$ & 676.46 & 58.12 & 0.59 & 11.05 & 4.37 & 2.22 & 18.57 & 1.90 & 2.65 & 0.14 & 411 & 489 & 74 & 13 & 16 & NA \\
\hline $72 \mathrm{R}-1,64-65$ & 680.44 & 71.78 & 0.65 & 11.96 & 4.19 & 2.17 & 3.92 & 2.18 & 2.90 & 0.15 & 511 & 197 & 97 & 13 & 9 & NA \\
\hline $72 \mathrm{R}-2,91-92$ & 682.17 & 69.73 & 0.69 & 14.00 & 5.68 & 2.78 & 1.10 & 2.15 & 3.64 & 0.13 & 626 & 135 & 133 & 16 & 14 & 64 \\
\hline 73R-2, 13-14 & 690.96 & 65.54 & 0.63 & 11.73 & 4.23 & 2.35 & 10.24 & 1.98 & 2.88 & 0.1 & 442 & 268 & 91 & 11 & 14 & NA \\
\hline $75 R-1,15-16$ & 708.75 & 68.13 & 0.67 & 12.25 & 4.77 & 2.29 & 6.69 & 2.11 & 2.75 & 0.13 & 532 & 235 & 94 & 15 & 8 & NA \\
\hline $75 \mathrm{R}-1,123-124$ & 709.83 & 71.73 & 0.67 & 13.24 & 5.24 & 2.65 & 0.94 & 1.99 & 3.33 & 0.12 & 618 & 118 & 108 & 16 & 15 & NA \\
\hline $76 \mathrm{R}-4,22-23$ & 722.41 & 69.09 & 0.58 & 11.08 & 5.18 & 2.50 & 6.88 & 1.74 & 2.61 & 0.13 & 439 & 228 & 80 & 14 & 11 & NA \\
\hline 78R-1, 142-143 & 738.82 & 65.41 & 0.71 & 13.26 & 5.00 & 2.65 & 7.61 & 1.91 & 3.04 & 0.14 & 490 & 256 & 103 & 14 & 13 & NA \\
\hline 78R-3, 102-103 & 741.18 & 71.43 & 0.68 & 13.58 & 5.16 & 2.63 & 1.06 & 1.96 & 3.25 & 0.15 & 700 & 124 & 115 & 17 & 15 & 65 \\
\hline $79 \mathrm{R}-4,99-100$ & 752.35 & 71.60 & 0.66 & 13.23 & 5.54 & 2.78 & 0.87 & 1.86 & 3.24 & 0.12 & 578 & 109 & 119 & 17 & 13 & 67 \\
\hline $82 \mathrm{R}-1,29-30$ & 776.09 & 72.01 & 0.68 & 12.52 & 6.03 & 2.79 & 0.83 & 1.87 & 3.06 & 0.11 & 572 & 109 & 108 & 19 & 15 & 65 \\
\hline $82 \mathrm{R}-3,54-55$ & 779.08 & 72.47 & 0.69 & 13.19 & 4.84 & 2.47 & 1.05 & 1.99 & 3.09 & 0.12 & 795 & 127 & 109 & 16 & 15 & 64 \\
\hline
\end{tabular}


Table T14 (continued).

\begin{tabular}{|c|c|c|c|c|c|c|c|c|c|c|c|c|c|c|c|c|}
\hline \multirow{2}{*}{$\begin{array}{l}\text { Core, section, } \\
\text { interval }(\mathrm{cm})\end{array}$} & \multirow{2}{*}{$\begin{array}{l}\text { Depth } \\
\text { (mbsf) }\end{array}$} & \multicolumn{9}{|c|}{ Major element oxide (wt\%) } & \multicolumn{5}{|c|}{ Trace element (ppm) } & \multirow[b]{2}{*}{$\mathrm{CIA}$} \\
\hline & & $\mathrm{SiO}_{2}$ & $\mathrm{TiO}_{2}$ & $\mathrm{Al}_{2} \mathrm{O}_{3}$ & $\mathrm{Fe}_{2} \mathrm{O}_{3}$ & $\mathrm{MgO}$ & $\mathrm{CaO}$ & $\mathrm{Na}_{2} \mathrm{O}$ & $\mathrm{K}_{2} \mathrm{O}$ & $\mathrm{P}_{2} \mathrm{O}_{5}$ & $\mathrm{Ba}$ & $\mathrm{Sr}$ & V & Sc & Co & \\
\hline $84 \mathrm{R}-2,57-59$ & 797.06 & 25.16 & 0.30 & 5.16 & 2.00 & 2.31 & 61.50 & 0.79 & 1.09 & 0.26 & 416 & 257 & 16 & 4 & 8 & NA \\
\hline 84R-2, 132-133 & 797.81 & 72.94 & 0.68 & 12.43 & 5.17 & 2.49 & 1.51 & 1.91 & 2.66 & 0.10 & 811 & 135 & 108 & 19 & 17 & 61 \\
\hline $85 R-3,126-128$ & 808.25 & 72.56 & 0.65 & 12.30 & 4.74 & 2.37 & 2.61 & 1.96 & 2.62 & 0.10 & 1050 & 172 & 106 & 18 & 14 & NA \\
\hline $86 R-4,81-83$ & 818.79 & 70.87 & 0.71 & 13.25 & 5.77 & 2.95 & 1.13 & 1.97 & 3.16 & 0.13 & 614 & 113 & 115 & 17 & 13 & NA \\
\hline 87R-7, 29-31 & 832.55 & 70.01 & 0.76 & 13.42 & 6.56 & 2.90 & 1.11 & 1.96 & 3.11 & 0.10 & 626 & 111 & 123 & 20 & 15 & 65 \\
\hline 88R-1, 95-96 & 834.45 & 69.17 & 0.75 & 13.33 & 6.44 & 2.90 & 2.20 & 1.95 & 3.07 & 0.10 & 632 & 140 & 118 & 18 & 13 & 65 \\
\hline 89R-3, 117-118 & 846.88 & 72.48 & 0.66 & 12.75 & 5.34 & 2.59 & 1.11 & 1.93 & 2.95 & 0.11 & 702 & 111 & 110 & 16 & 14 & 64 \\
\hline $92 \mathrm{R}-3,44-45$ & 874.46 & 73.69 & 0.68 & 12.08 & 5.14 & 2.55 & 1.17 & 1.81 & 2.74 & 0.08 & 613 & 99 & 109 & 16 & 12 & 63 \\
\hline $93 R-2,38-39$ & 878.33 & 70.96 & 0.71 & 13.12 & 6.02 & 2.58 & 1.35 & 1.96 & 3.14 & 0.12 & 673 & 128 & 136 & 20 & 13 & 63 \\
\hline 93R-3, 100-101 & 880.05 & 66.03 & 0.82 & 15.98 & 8.81 & 3.37 & 0.87 & 2.29 & 1.72 & 0.09 & 589 & 145 & 130 & 14 & 15 & 67 \\
\hline 93R-CC, 16-17 & 880.68 & 67.15 & 0.88 & 15.97 & 7.98 & 3.22 & 0.86 & 2.21 & 1.62 & 0.10 & 586 & 138 & 142 & 12 & 15 & 68 \\
\hline $94 R-2,50-51$ & 883.38 & 74.27 & 0.77 & 12.82 & 4.76 & 2.14 & 0.67 & 1.77 & 2.67 & 0.09 & 565 & 101 & 107 & 19 & 35 & 68 \\
\hline 94R-3, 116-117 & 885.47 & 65.80 & 0.88 & 16.37 & 8.56 & 3.27 & 0.81 & 2.15 & 2.07 & 0.08 & 591 & 134 & 139 & 17 & 12 & 69 \\
\hline $95 R-3,93-94$ & 894.79 & 57.10 & 1.19 & 24.00 & 10.52 & 2.43 & 0.64 & 1.58 & 2.42 & 0.09 & 555 & 108 & 157 & 20 & 13 & 81 \\
\hline $95 R-4,47-48$ & 895.42 & 85.03 & 0.58 & 8.04 & 2.46 & 0.62 & 0.18 & 0.75 & 2.28 & 0.03 & 565 & 73 & 40 & 7 & 13 & 77 \\
\hline 96R-CC, 16-17 & 900.76 & 57.01 & 1.32 & 25.38 & 9.71 & 1.88 & 0.51 & 1.23 & 2.82 & 0.11 & 687 & 95 & 162 & 21 & 19 & 86 \\
\hline $97 R-1,57-58$ & 910.77 & 72.97 & 0.83 & 14.62 & 5.37 & 1.21 & 0.56 & 1.00 & 3.29 & 0.07 & 675 & 88 & 102 & 13 & 11 & 80 \\
\hline $98 R-2,15-17$ & 921.10 & 61.53 & 1.12 & 23.37 & 6.97 & 2.29 & 0.83 & 1.69 & 2.00 & 0.20 & 549 & 129 & 195 & 23 & 17 & 79 \\
\hline $98 R-5,80-81$ & 925.18 & 57.87 & 1.02 & 22.28 & 12.03 & 1.91 & 1.05 & 1.43 & 1.93 & 0.43 & 512 & 115 & 102 & 17 & 11 & 79 \\
\hline 99R-1, 80-81 & 930.20 & 60.32 & 1.11 & 25.00 & 7.02 & 1.94 & 0.71 & 1.31 & 2.40 & 0.16 & 585 & 107 & 159 & 19 & 13 & 84 \\
\hline 100R-1, 67-68 & 939.77 & 59.46 & 1.12 & 25.13 & 7.67 & 1.77 & 0.63 & 1.29 & 2.82 & 0.09 & 587 & 94 & 206 & 24 & 15 & NA \\
\hline $101 \mathrm{R}-2,109-110$ & 951.39 & 61.98 & 1.06 & 20.64 & 9.70 & 1.97 & 0.69 & 1.63 & 2.24 & 0.09 & 543 & 112 & 192 & 17 & 18 & 78 \\
\hline $102 \mathrm{R}-1,46-47$ & 958.86 & 60.97 & 1.14 & 23.68 & 7.91 & 1.85 & 0.68 & 1.49 & 2.17 & 0.10 & 577 & 112 & 205 & 19 & 15 & 82 \\
\hline 103R-4, 117-119 & 973.67 & 61.69 & 1.12 & 23.44 & 7.40 & 1.84 & 0.62 & 1.41 & 2.38 & 0.09 & 517 & 104 & 240 & 19 & 17 & 83 \\
\hline $104 \mathrm{R}-3,133-134$ & 981.88 & 61.58 & 1.18 & 24.75 & 6.48 & 1.68 & 0.56 & 1.25 & 2.41 & 0.10 & 481 & 98 & 221 & 20 & 16 & 85 \\
\hline $105 \mathrm{R}-2,82-84$ & 989.42 & 61.48 & 1.10 & 23.29 & 7.76 & 1.81 & 0.62 & 1.41 & 2.44 & 0.08 & 547 & 105 & 209 & 19 & 16 & 82 \\
\hline 106R-1, 75-77 & 997.55 & 63.33 & 1.17 & 21.03 & 8.16 & 1.80 & 0.62 & 1.38 & 2.43 & 0.08 & 530 & 101 & 210 & 18 & 15 & 81 \\
\hline
\end{tabular}

Notes: Major element oxides normalized to $100 \mathrm{wt} \%$. Typical errors are 3\%-10\% for major elements and $7 \%-22 \%$ for minor elements. CIA = chemical index of alteration, calculated based on molar ratios of $\mathrm{Al}, \mathrm{Na}, \mathrm{K}$, and $\mathrm{Ca}$ (see text for more information). For the CIA calculations, all samples representing minor lithologies, samples with $\geq 10 \% \mathrm{CaCO}_{3}$, and diatom ooze samples were omitted. 
Plate P1. 1. Achomosphaera crassipellis (Sample 318-U1356A-106R-CC). 2. Aiora fenestrata (Sample 318-U1356A103R-CC). 3. Apectodinium homomorphum (Sample 318-U1356A-105R-CC). 4. Cerebrocysta bartonensis (Sample 318-U1356A-106R-CC). Scale bars $=20 \mu \mathrm{m}$. 5. Cleistosphaeridium placacanthum (Sample 318-U1356A-95R-CC). 6. Cleistosphaeridium diversispinosum (Sample 318-U1356A-106R-CC).

1 .

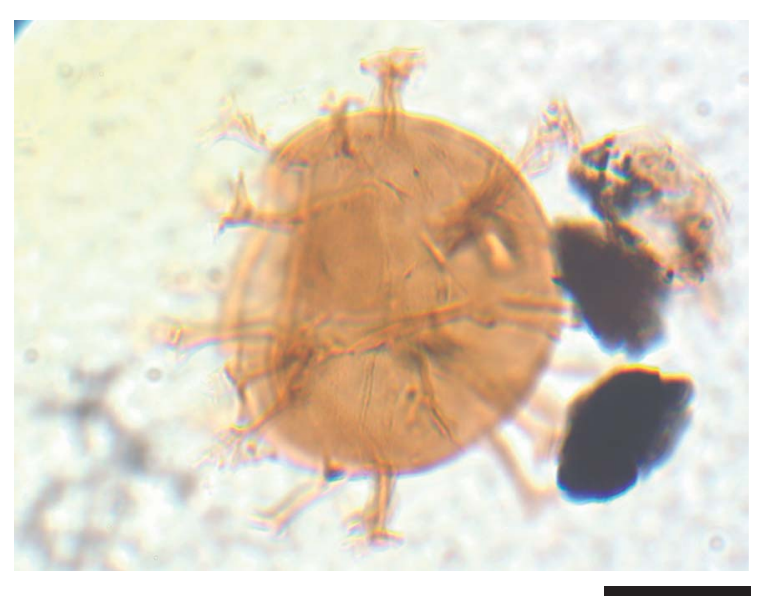

3

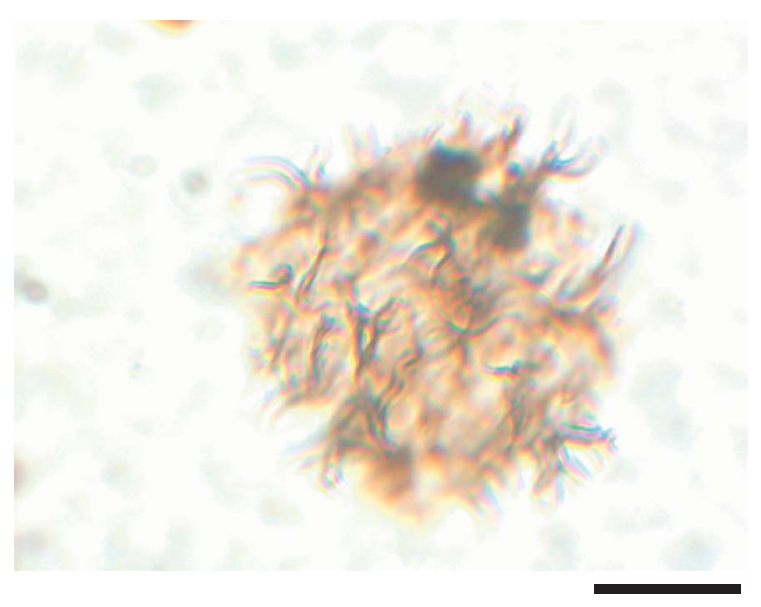

5

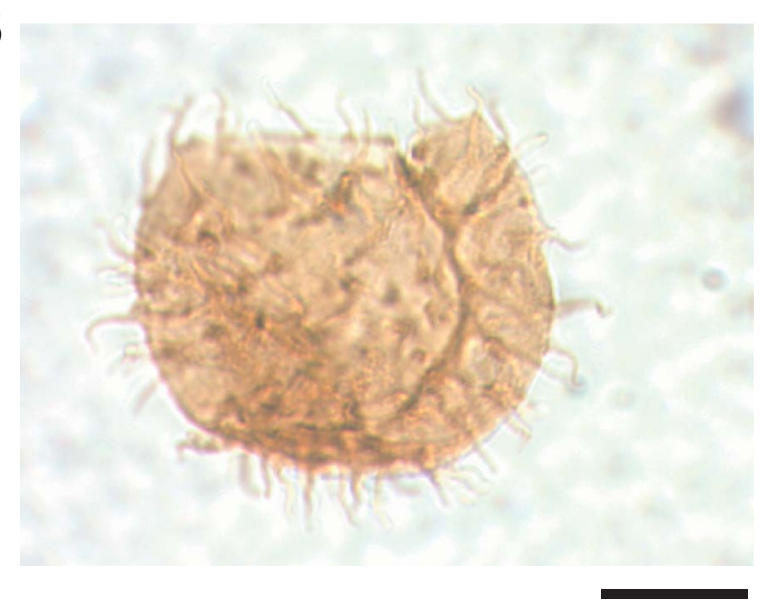

2

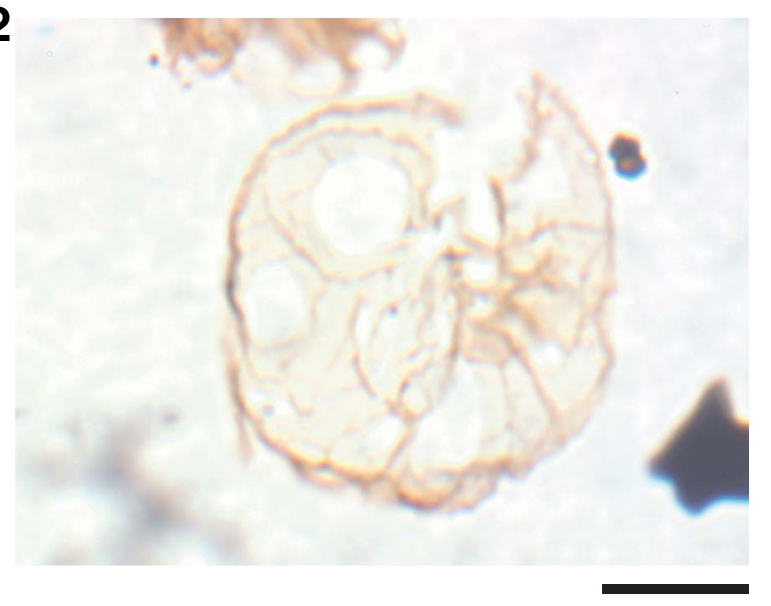

4

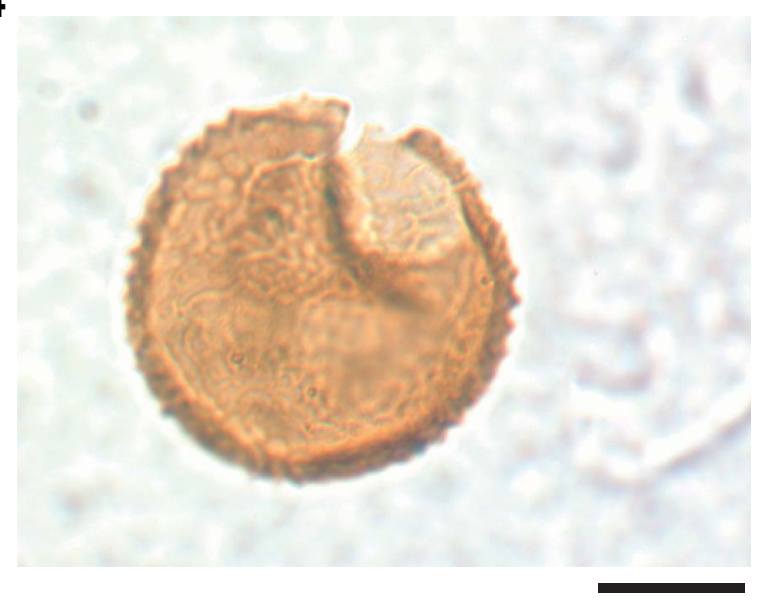

6

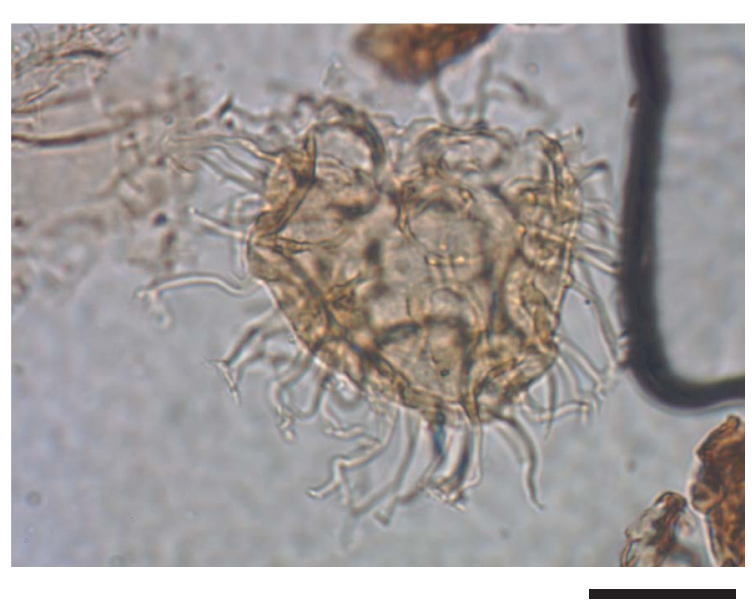


Plate P2. 1. Cordosphaeridium fibrospinosum (Sample 318-U1356A-106R-CC). 2. Dracodinium waipawaense (Sample 318-U1356A-102R-CC). 3. cf. Edwardsiella sp. (Sample 318-U1356A-14R-CC). 4. Eocladopyxis sp. (Sample 318-U1356A-101R-CC). 5. Heteraulacacysta sp. (Sample 318-U1356A-104R-CC). 6. Hystrichokolpoma truncatum (Sample 318-U1356A-93R-CC). Scale bars $=20 \mu \mathrm{m}$.

1

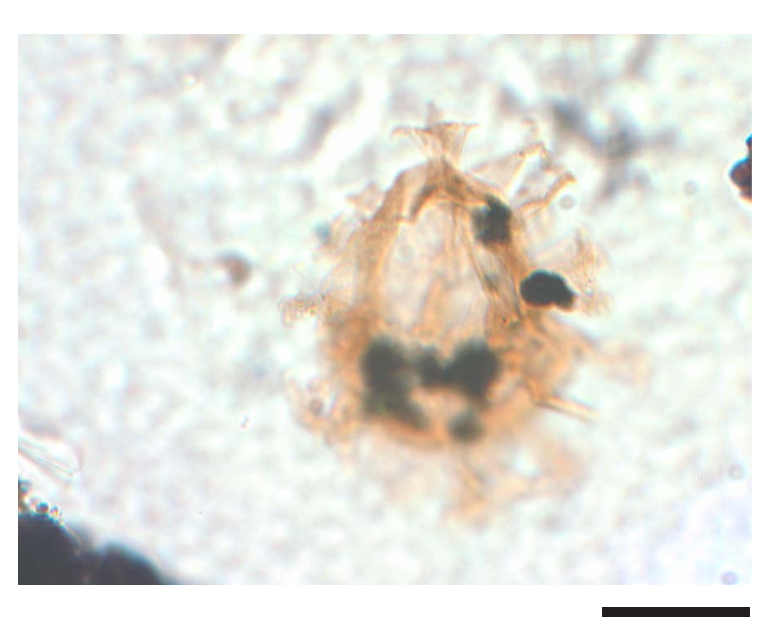

3

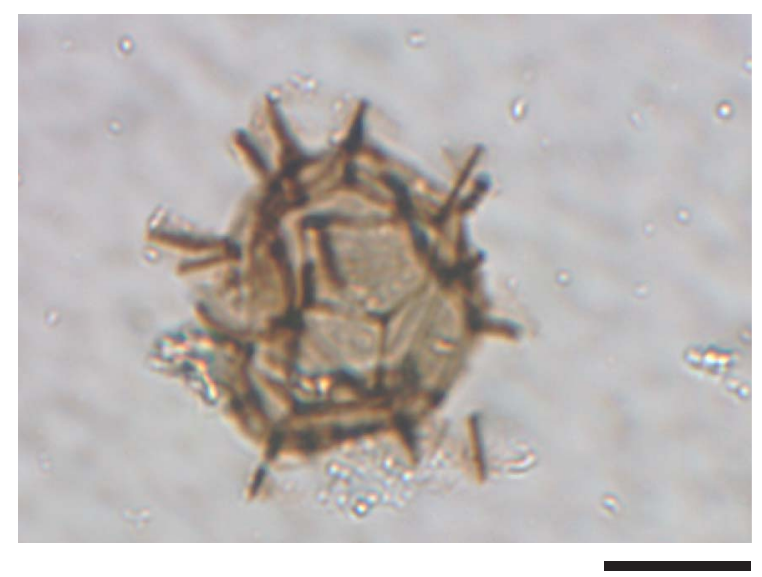

5

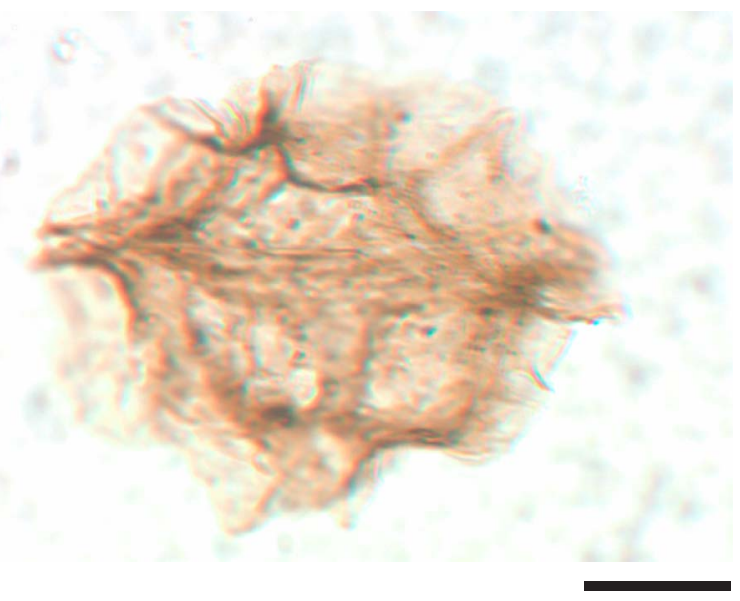

2

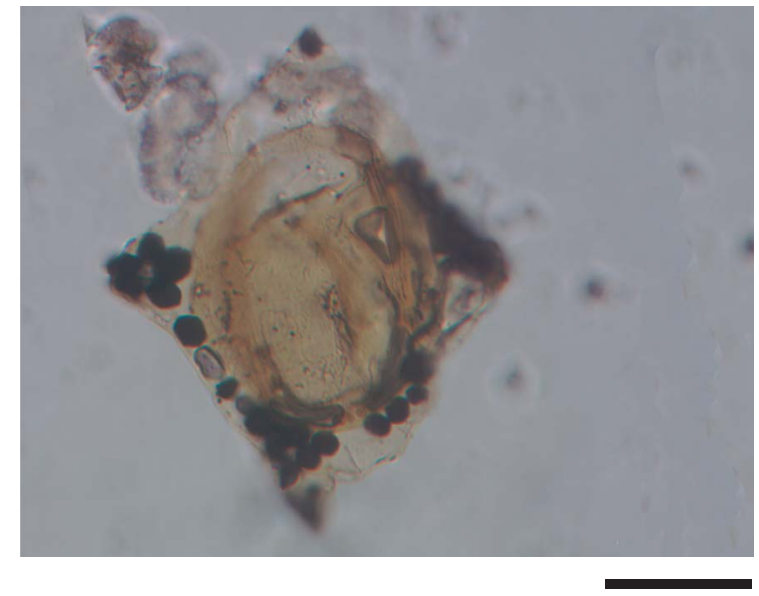

4

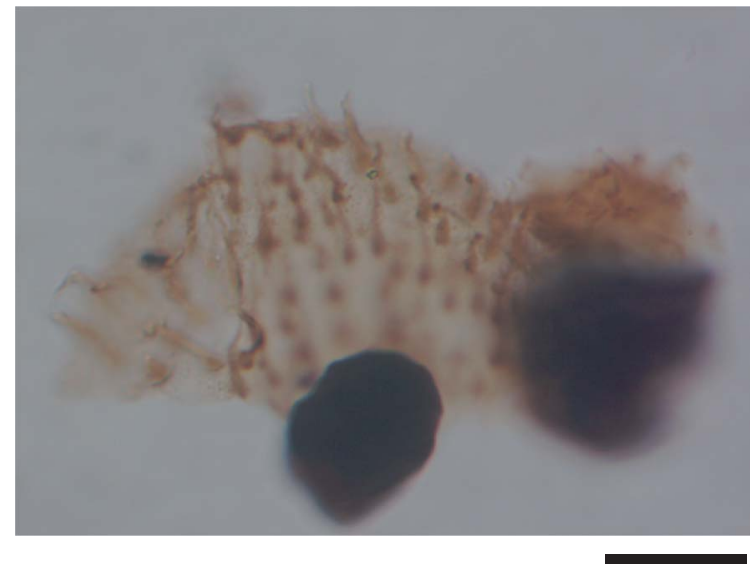

6

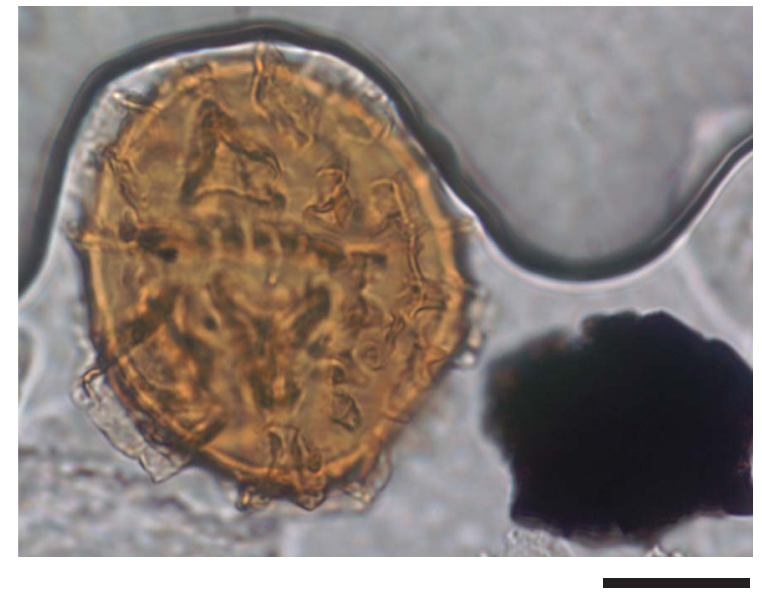


Plate P3. 1. Hystrichokolpoma truncatum (Sample 318-U1356A-93R-CC). 2. Hystrichosphaeridium tubiferum (Sample 318-U1356A-106R-CC). 3. Hystrichostrogylon membraniphora (Sample 318-U1356A-106R-CC). 4, 5. Kenleyia sp.; (4) Sample 318-U1356A-101R-CC, (5) Sample 318-U1356A-105R-CC. 6. Lejeunecysta sp. A (large) (Sample 318-U1356A-91R-1, 97-100 cm). Scale bars $=20 \mu \mathrm{m}$.

1

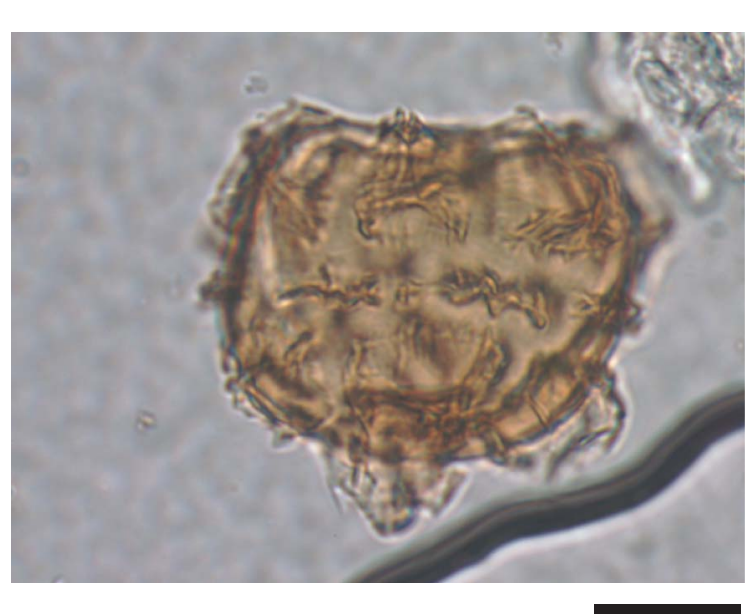

3

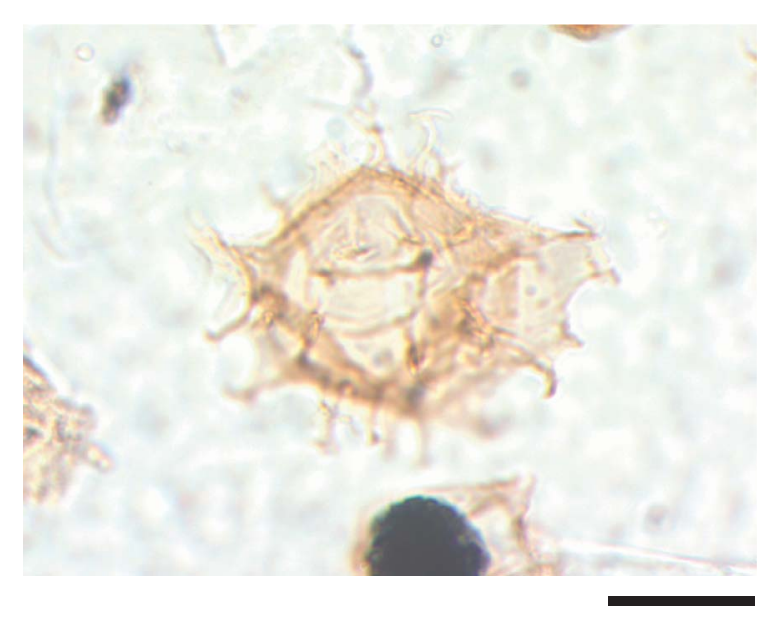

5

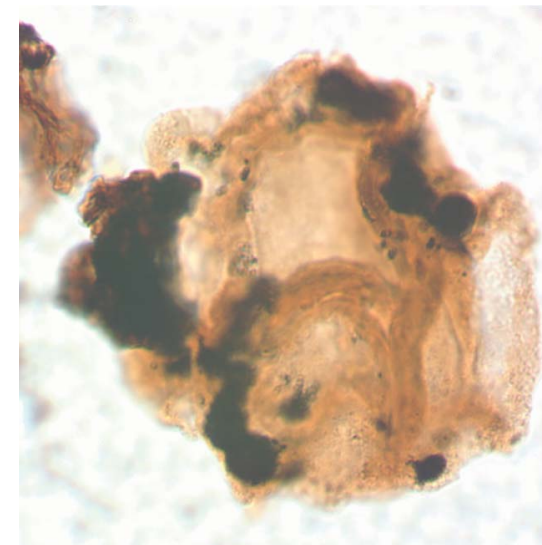

2

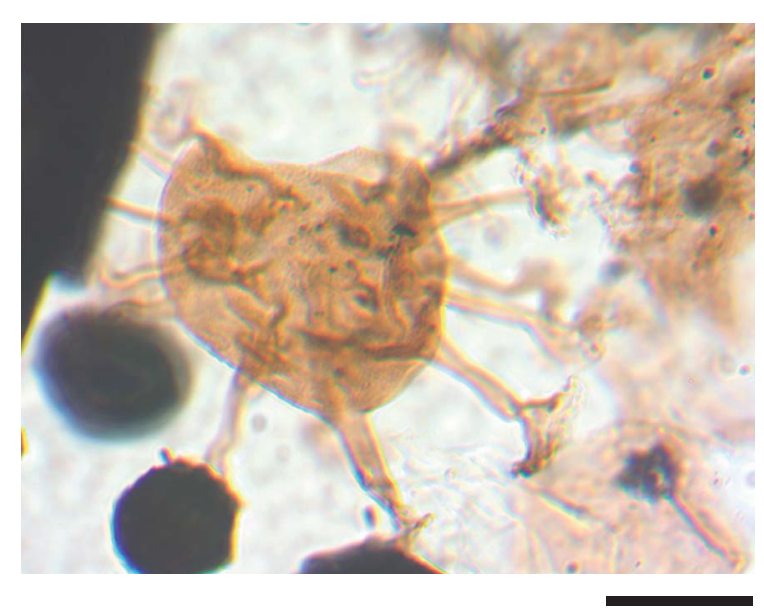

4

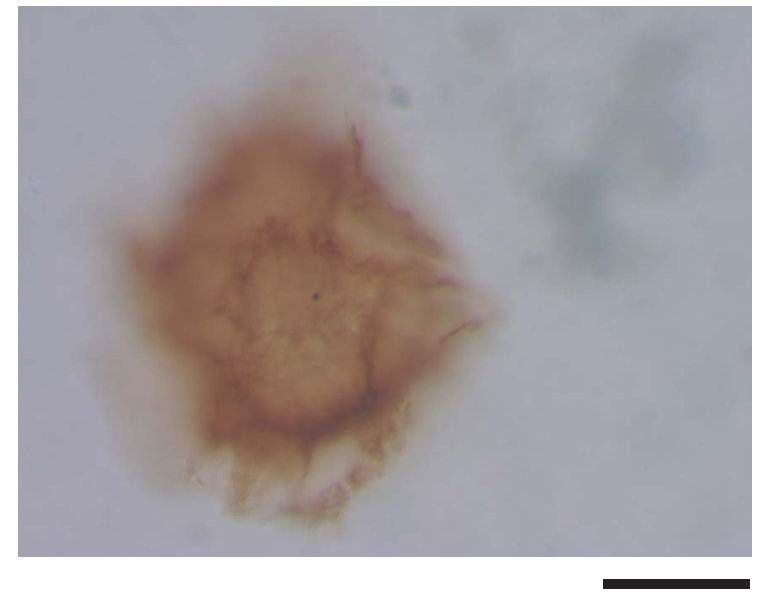

6

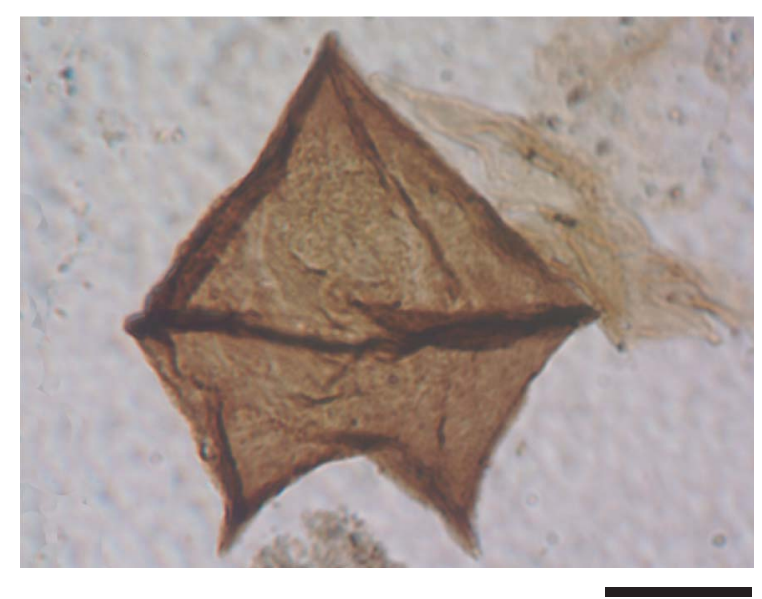


Plate P4. 1. Membranophoridium perforatum (Sample 318-U1356A-93R-CC). 2. Octodinium askiniae (Sample 318U1356A-100R-1, 75-76 cm). 3. Echinidinium sp. (Sample 318-U1356A-91R-1, 32-33 cm. 4, 5. Palaeocystodinium golzowense; (4) Sample 318-U1356A-103R-CC, (5) Sample 318-U1356A-106R-CC. 6. Phthanoperidinium sp. (Sample 318-U1356A-99R-CC). Scale bars $=20 \mu \mathrm{m}$.

1

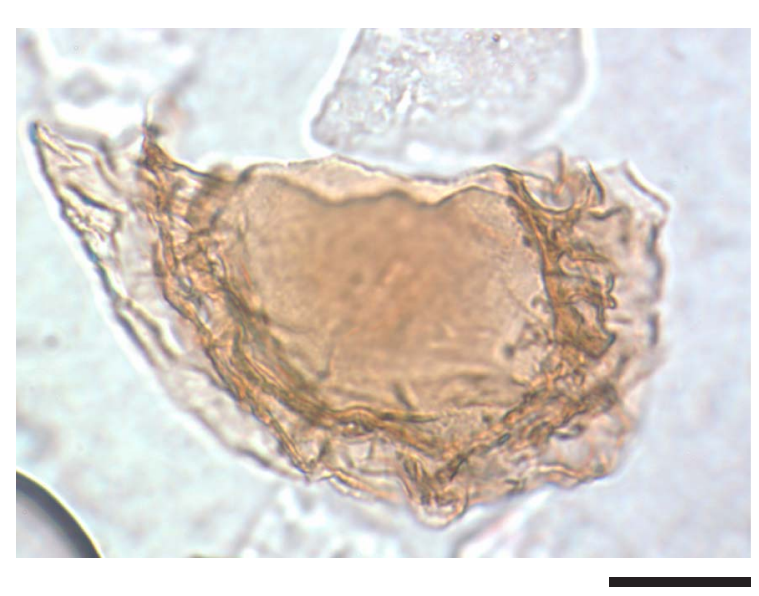

3

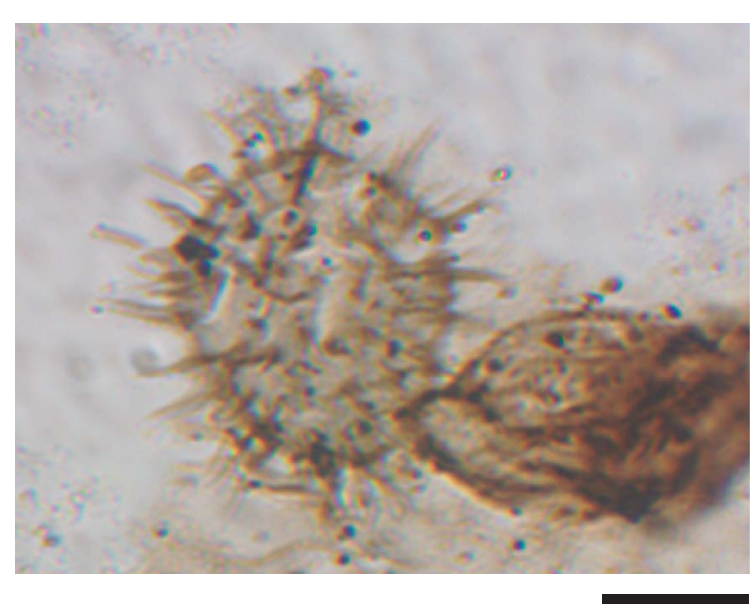

5

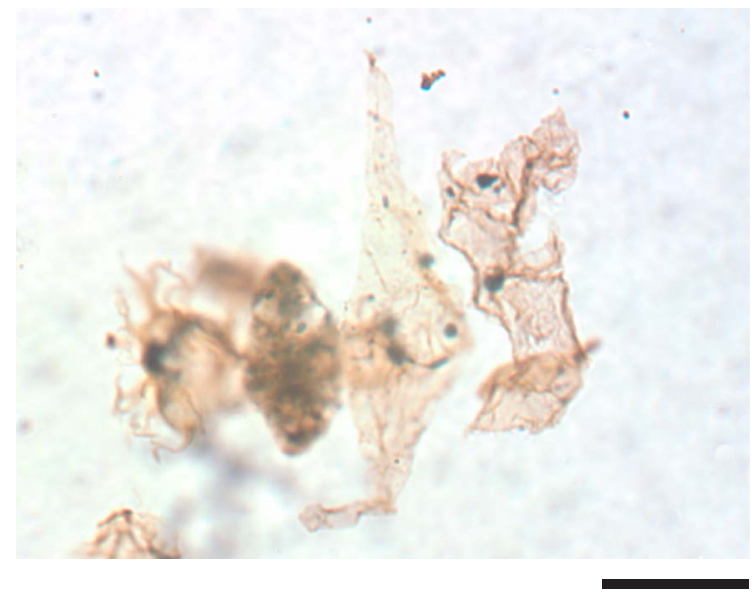

2

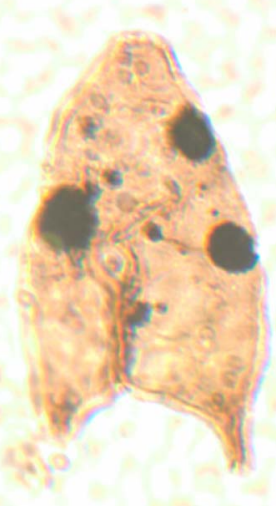

4

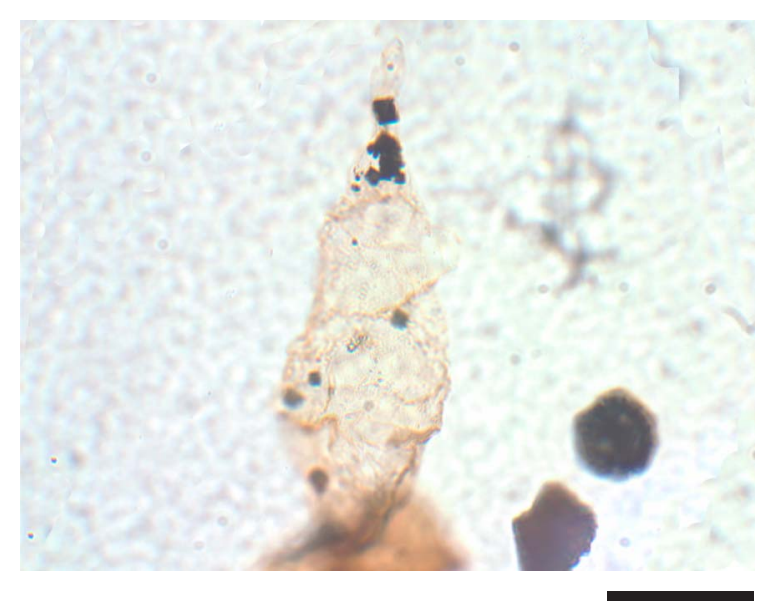

6

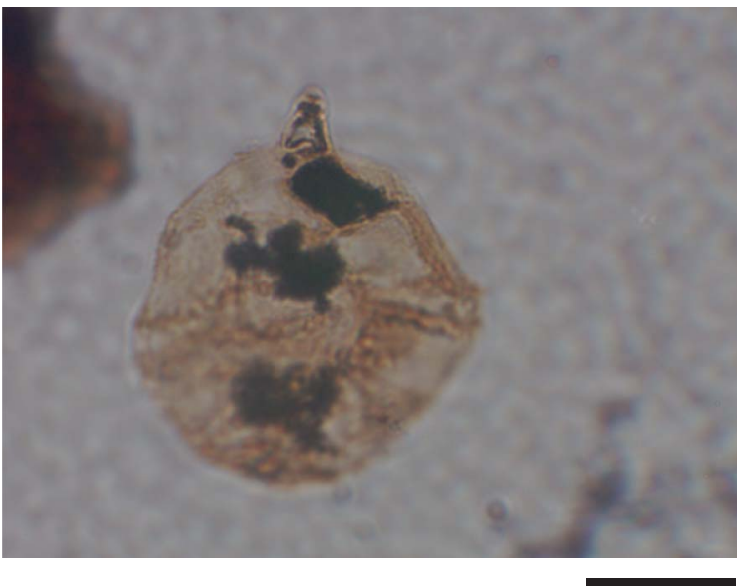


Plate P5. 1. Phthanoperidinium sp. (Sample 318-U1356A-100R-1, 75-76 cm). 2. Samlandia delicata (Sample 318U1356A-106R-CC). 3. Selenopemphix nephroides (Sample 318-U1356A-94R-CC). 4. Vozzhennikovia apertura (Sample 318-U1356A-106R-CC). Scale bars $=20 \mu \mathrm{m}$.

1

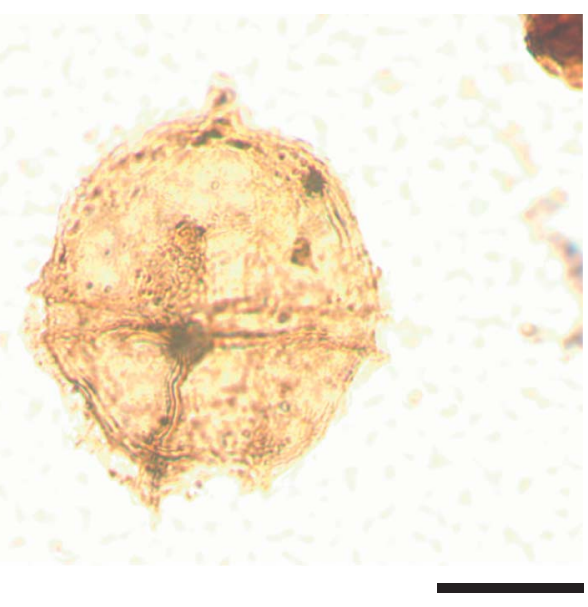

3

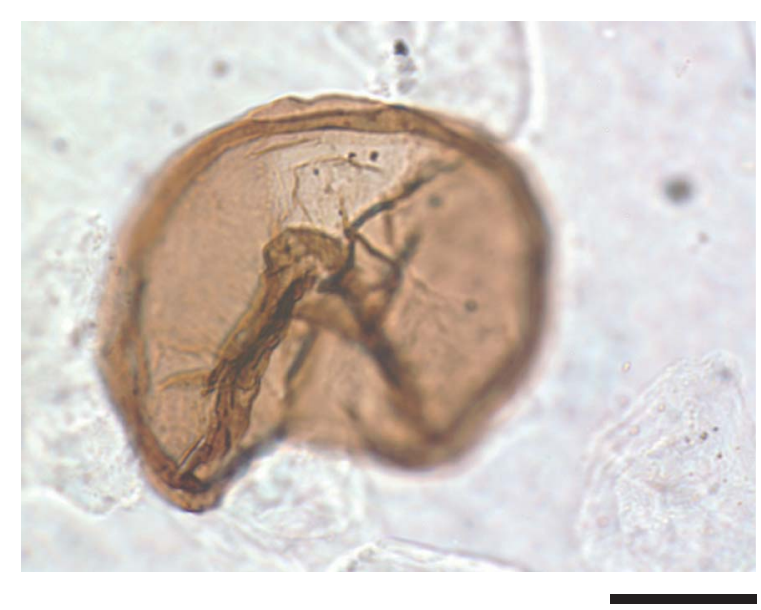

2

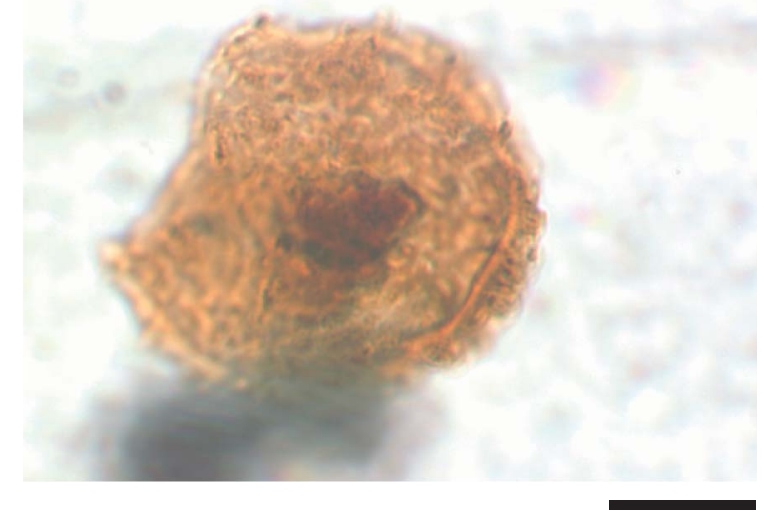

4

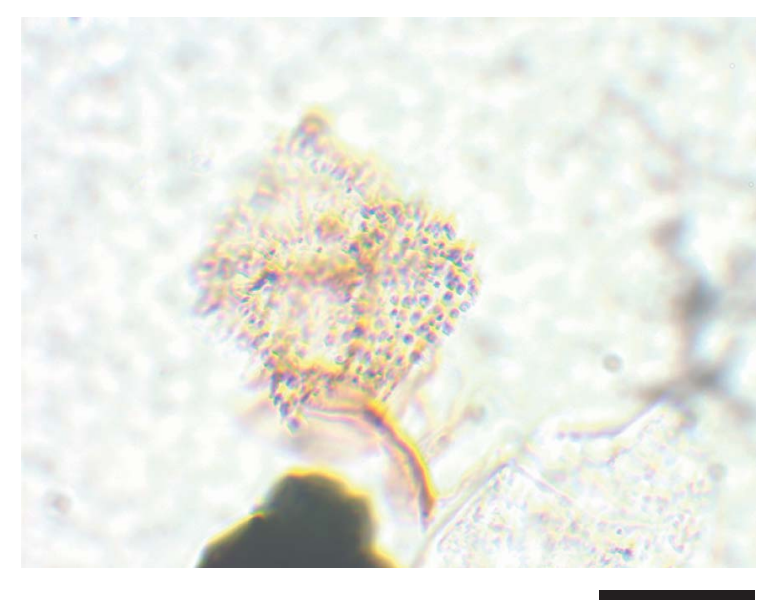


Plate P6. 1. Arachnodinium antarcticum (Sample 318-U1356A-94R-CC). 2. Forma T sensu Goodman and Ford, 1983 (Sample 318-U1356A-91R-1, 32-34 cm). 3, 4, 5. Brigantedinium sp.; (3) Sample 318-U1356A-1R-CC, (4) Sample 318-U1356A-14R-CC, (5) Sample 318-U1356A-82R-CC. 6. Cerebrocysta sp. A (Sample 318-U1356A55R-CC). Scale bars $=20 \mu \mathrm{m}$.

1

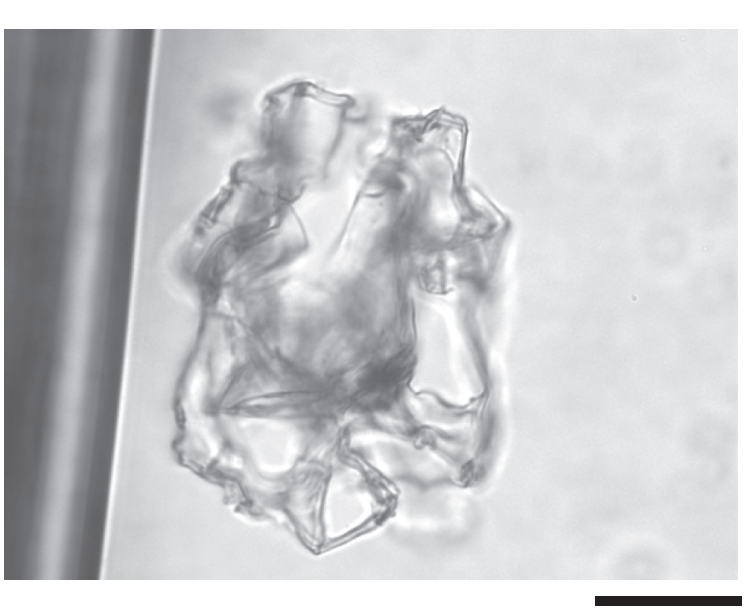

3

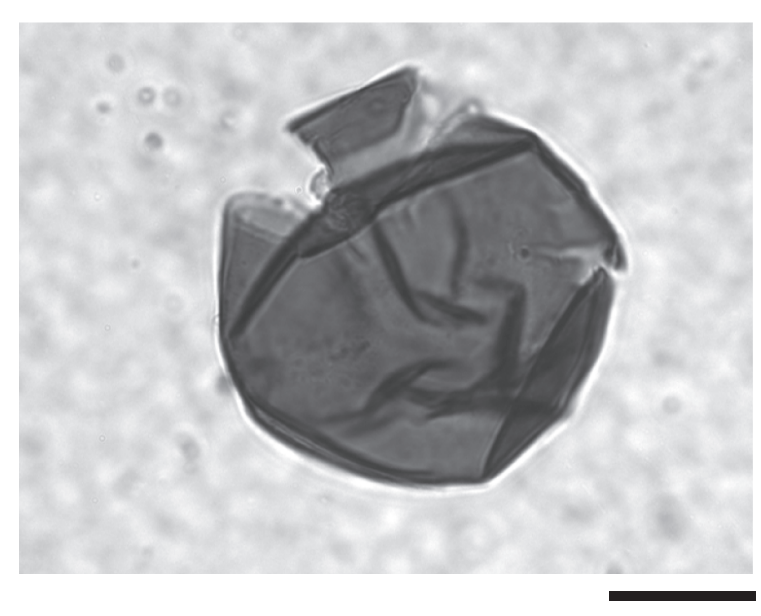

5

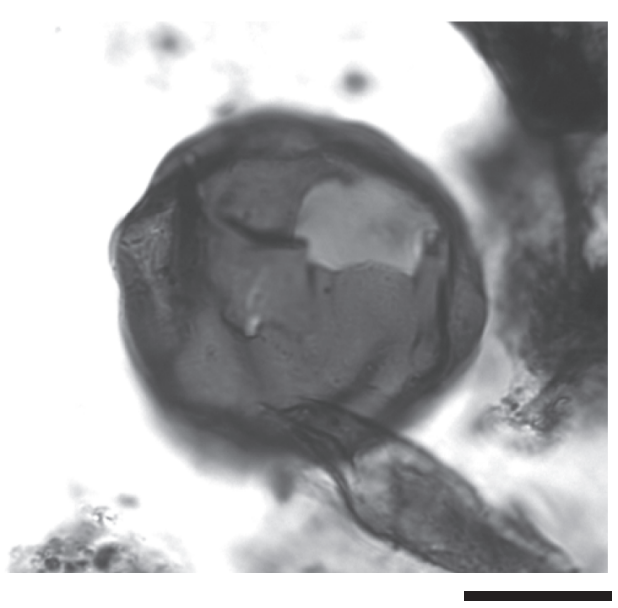

2

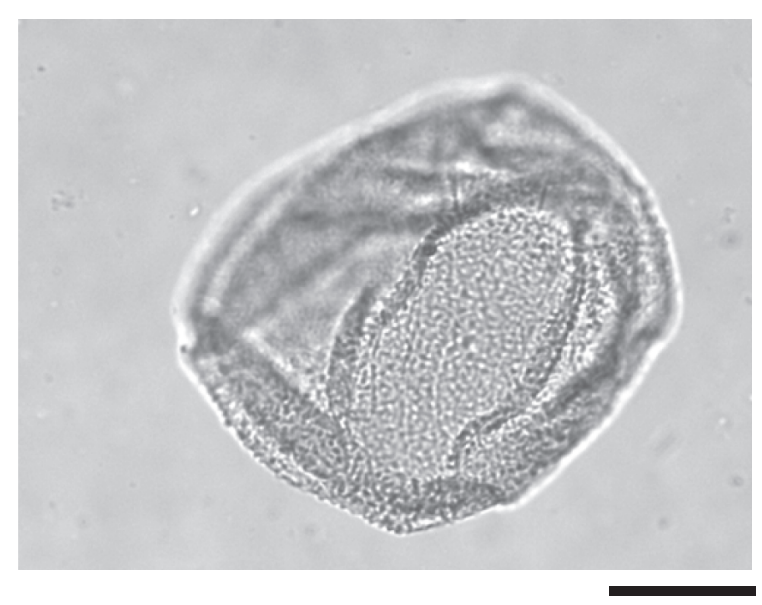

4

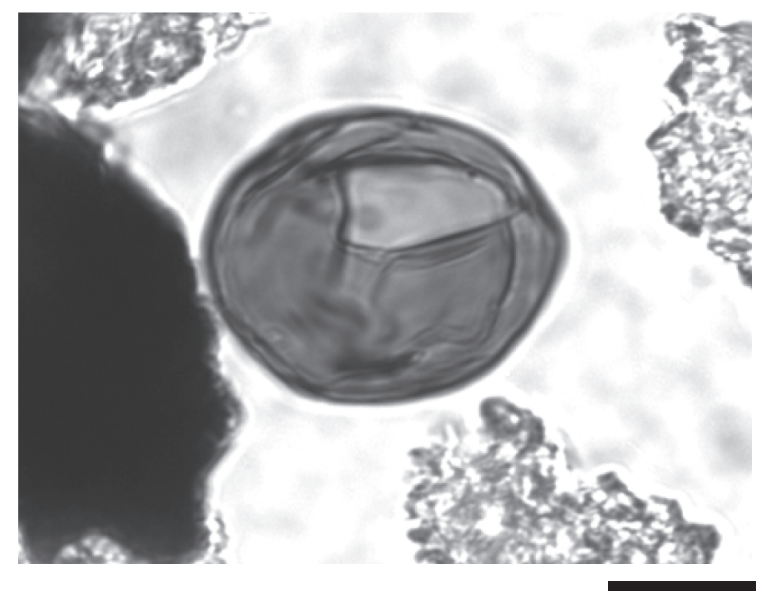

6

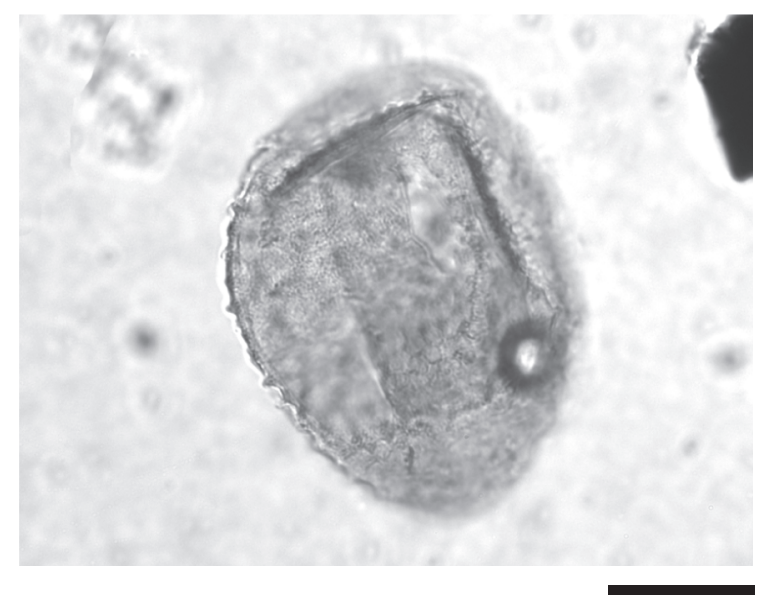


Plate P7. 1. Charlesdowniea coleothrypta (Sample 318-U1356A-95R-CC). 2. Charlesdowniea edwardsii (Sample 318-U1356A-95R-CC). 3. Cleistosphaeridium diversispinosum (Sample 318-U1356A-93R-CC). 4. Cleistosphaeridium placacanthum (Sample 318-U1356A 93R-CC). 5. Cymatiosphaera sp. (Sample 318-U1356A-14R-CC). 6. Deflandrea sp. A sensu Brinkhuis et al., 2003 (Sample 318-U1356A-72R-CC). Scale bars = $20 \mu \mathrm{m}$.

1

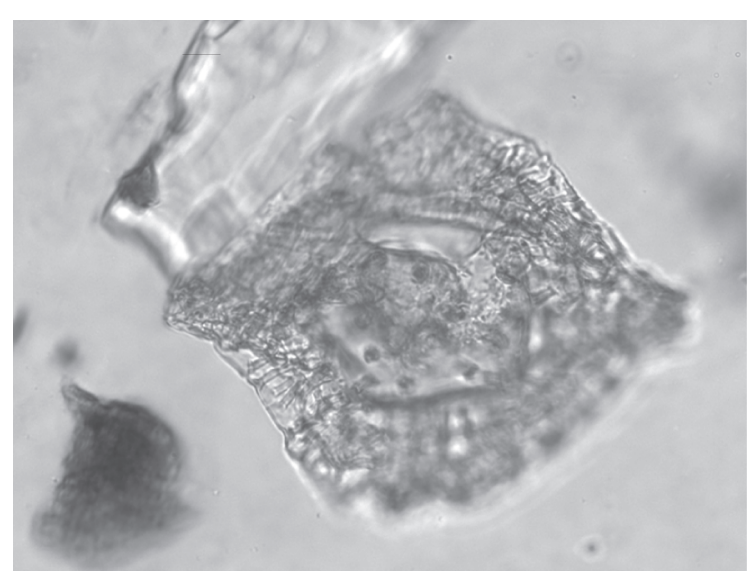

3

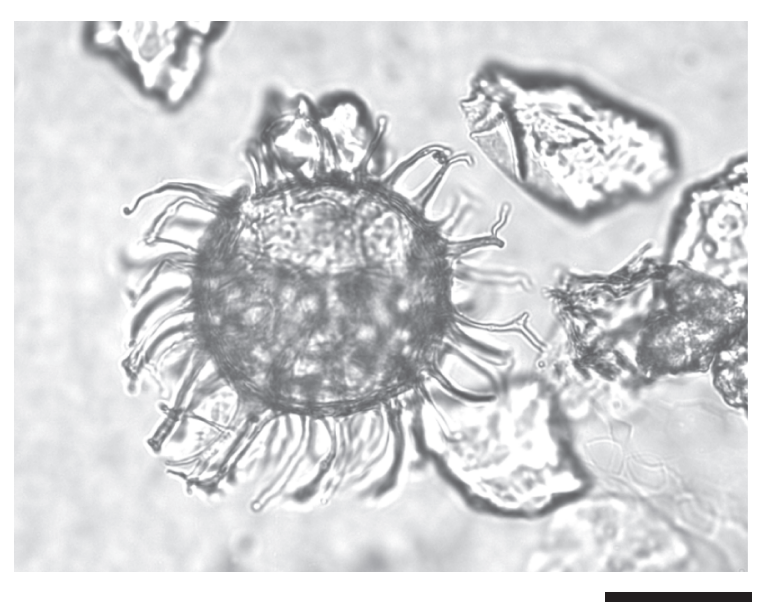

5

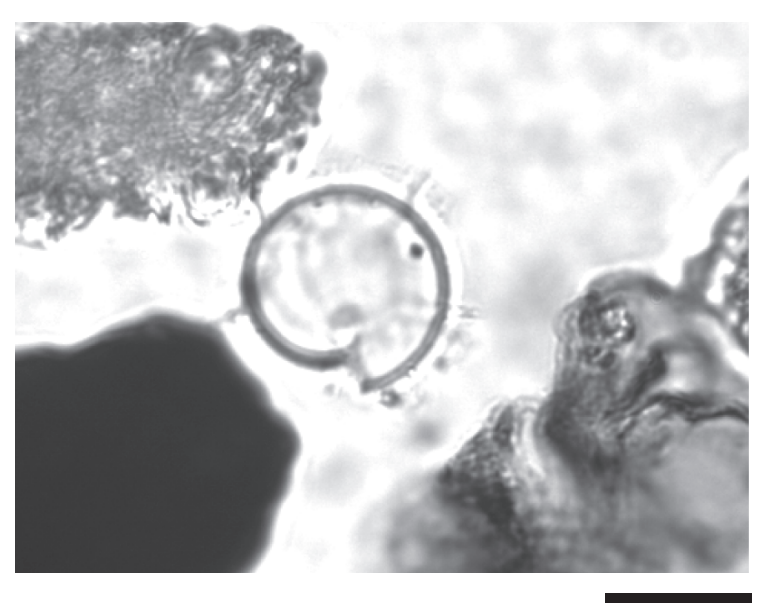

2

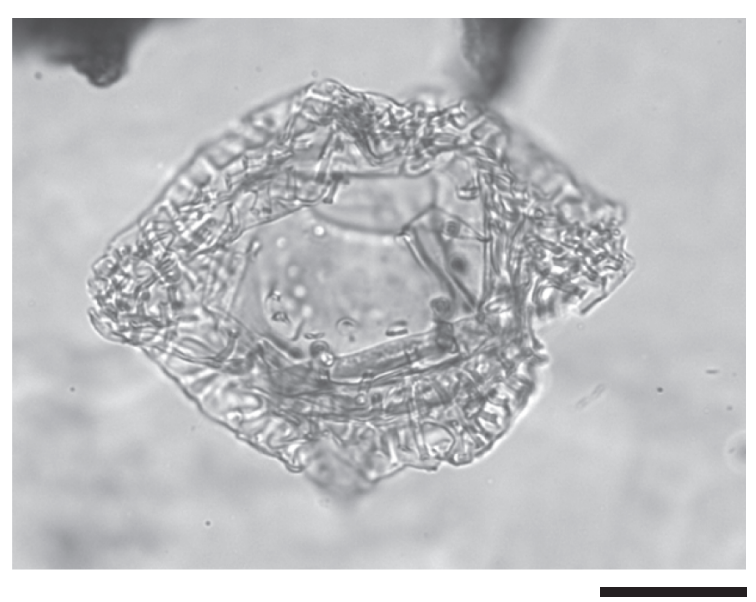

4

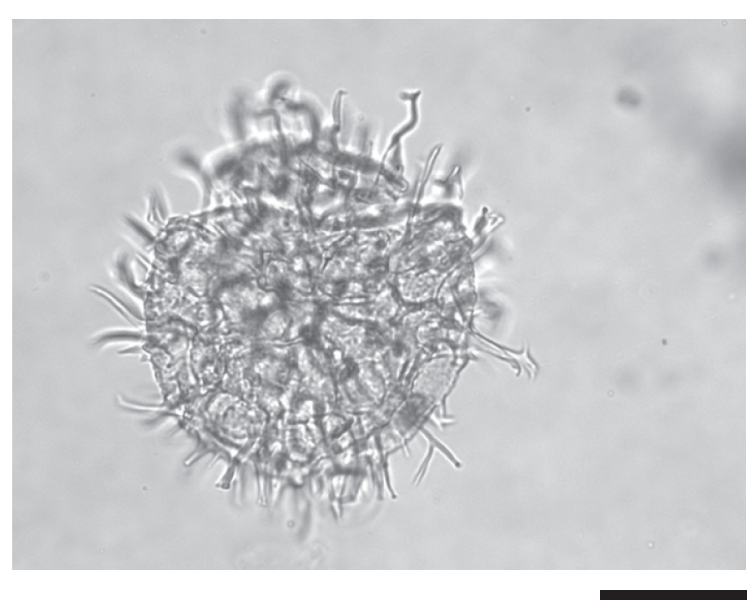

6

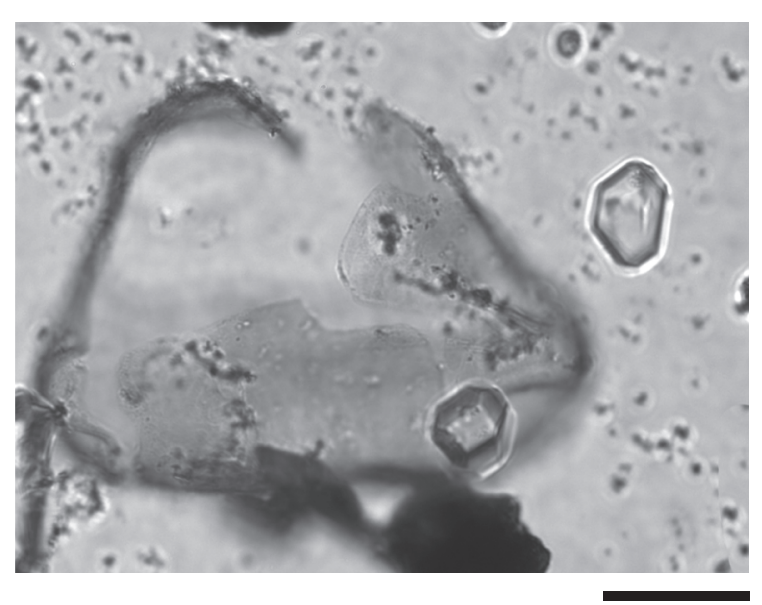


Plate P8. 1. Enneadocysta dictyostila (Sample 318-U1356A-14R-CC). 2, 3. Enneadocysta dictyostila (operculum) (Sample 318-U1356A-14R-CC). 4. Enneadocysta sp. (Sample 318-U1356A-72R-CC). 5. Homotryblium tasmaniensis (Sample 318-U1356A-95R-CC). 6. Impagidinium sp. (Sample 318-U1356A-14R-CC). Scale bars = $20 \mu \mathrm{m}$.

1

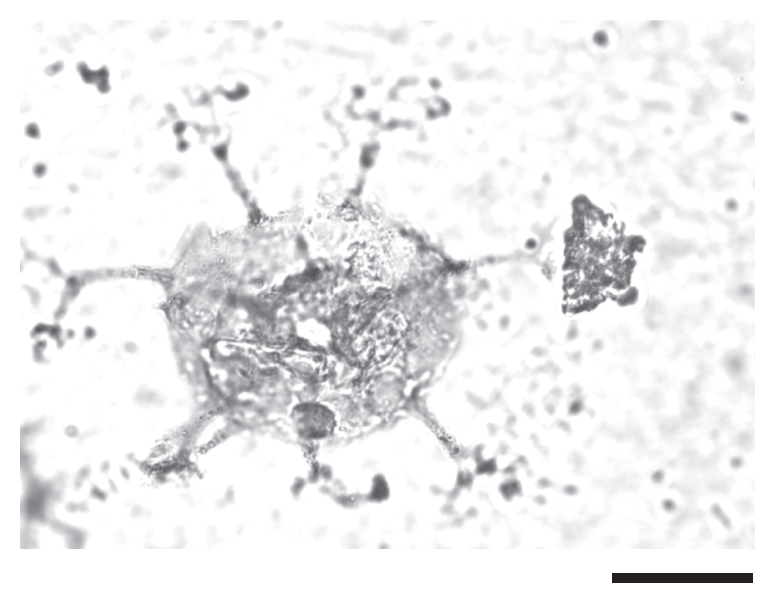

3

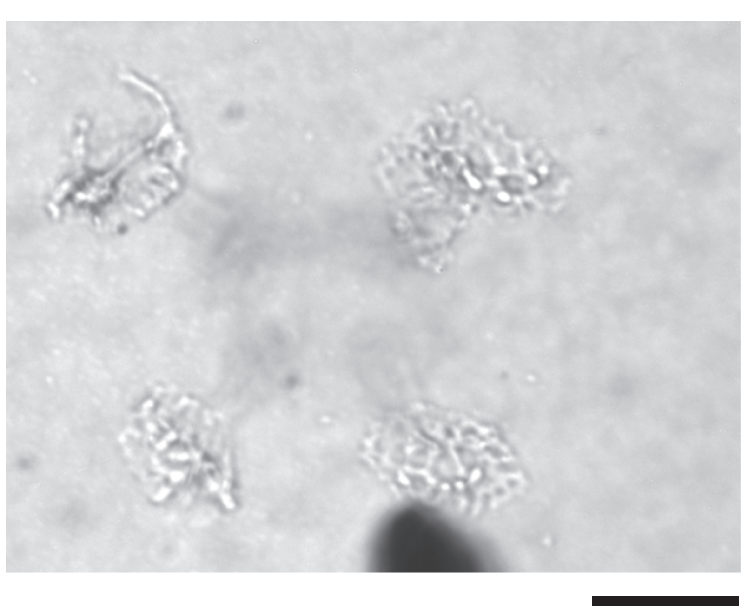

5

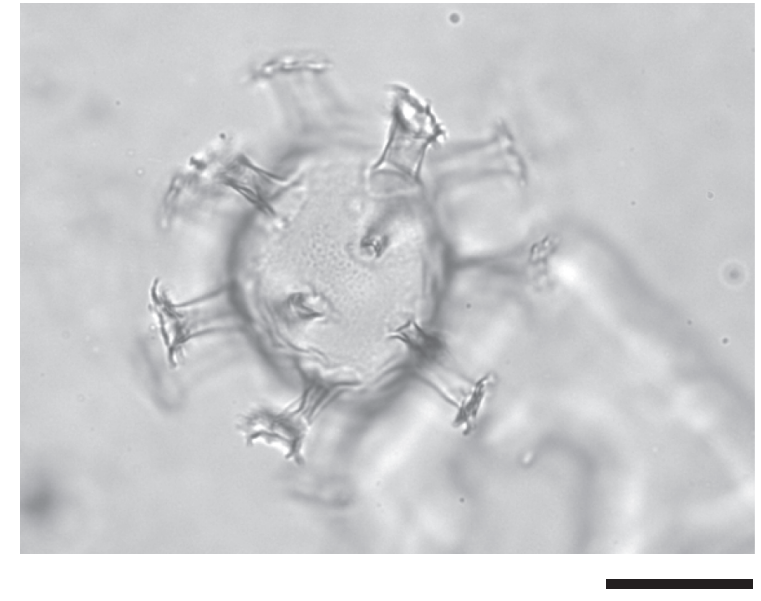

2

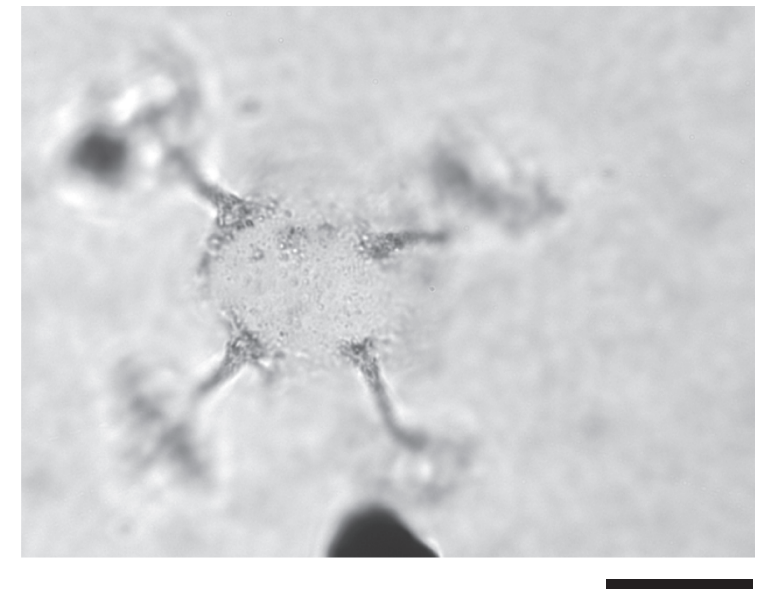

4

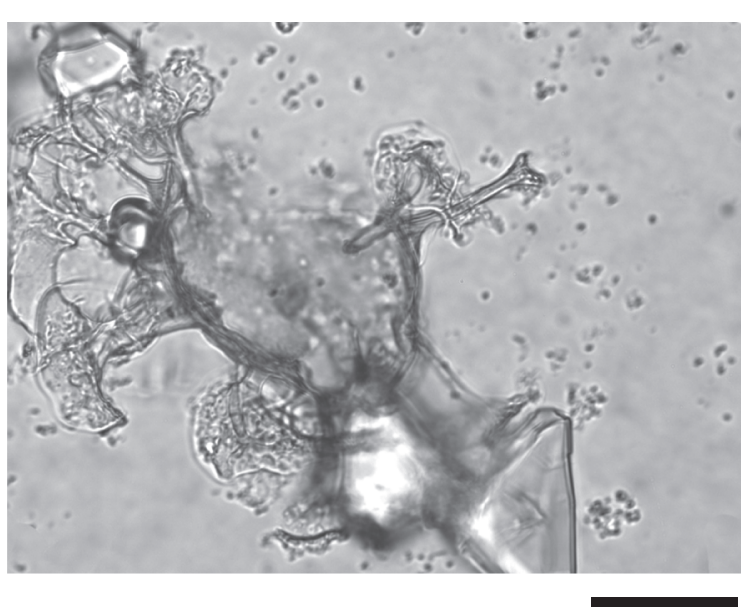

6

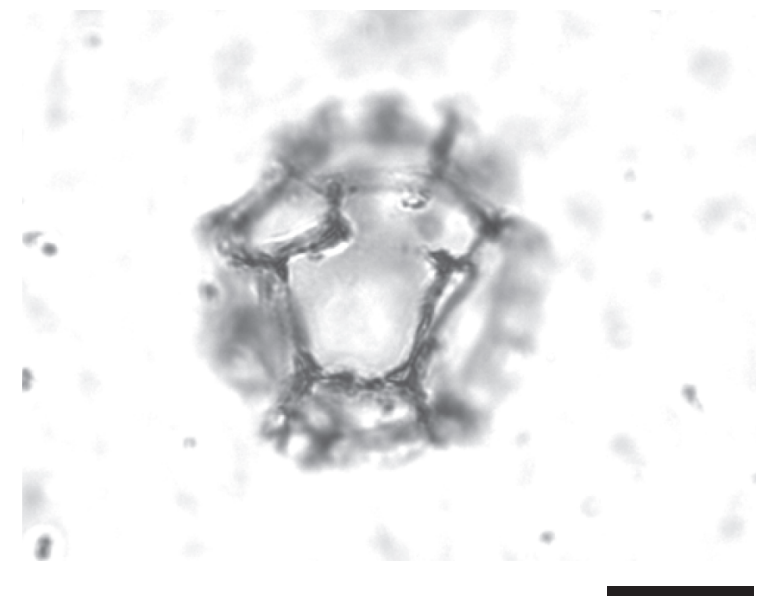


Plate P9. 1, 2. Impagidinium sphaericum (Sample 318-U1356A-55R-CC). 3. Islandinium sp. (Sample 318-U1356A14R-CC). 4, 5. Lejeunecysta sp. A (large); (4) Sample 318-U1356A-78R-CC, (5) Sample 318-U1356A-82R-CC. 6. Echinidinium sp. (Sample 318-U1356A-56R-CC). Scale bars $=20 \mu \mathrm{m}$.

1

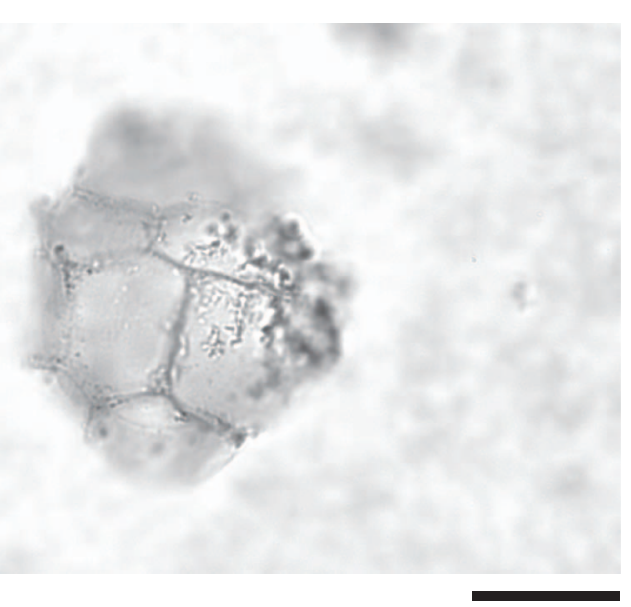

3

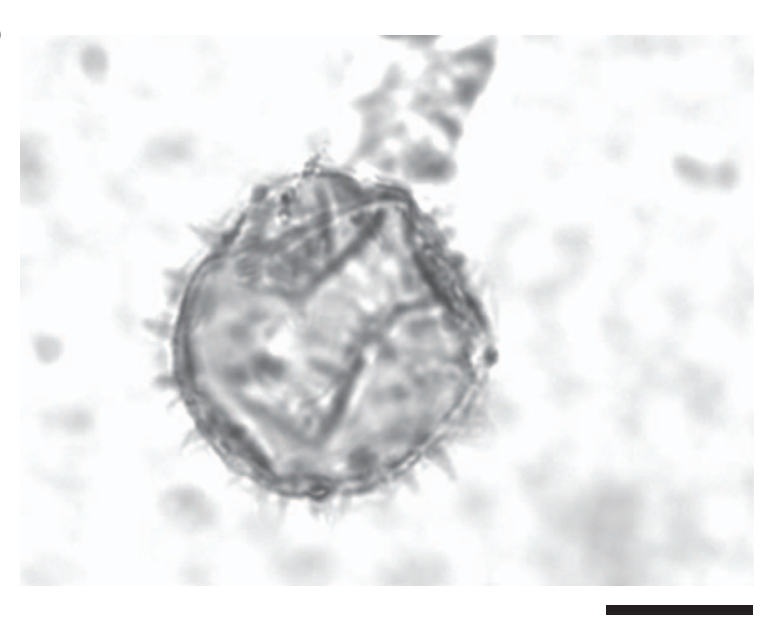

5

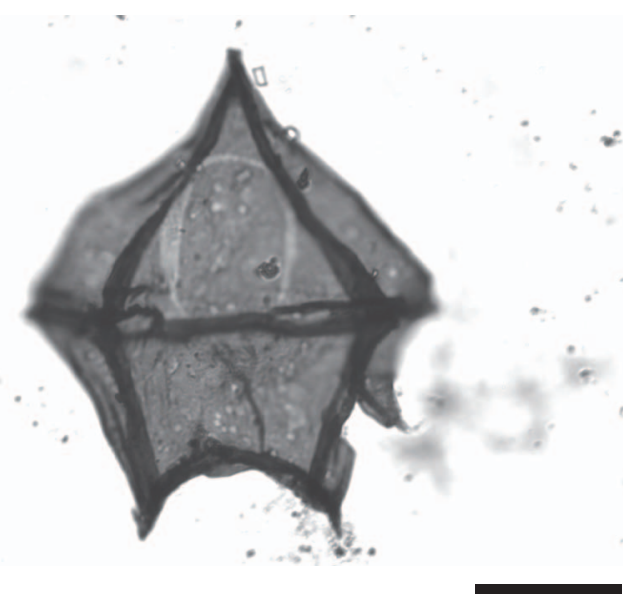

2

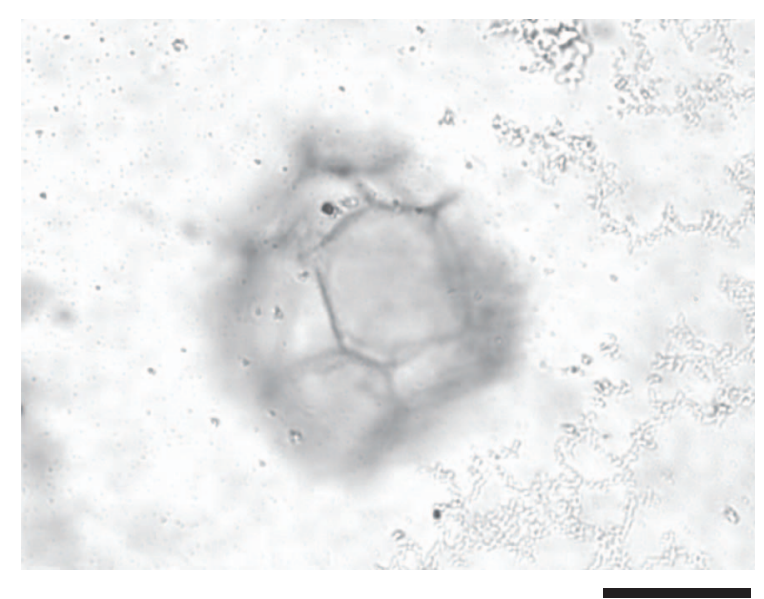

4

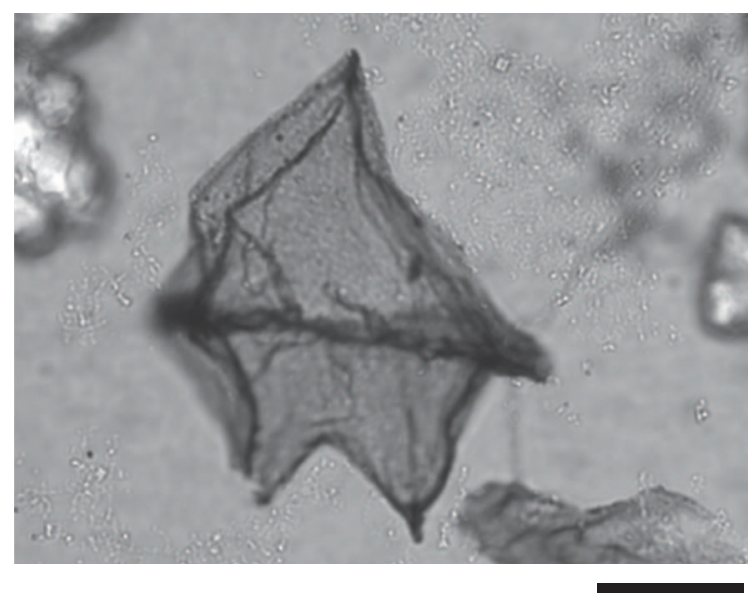

6

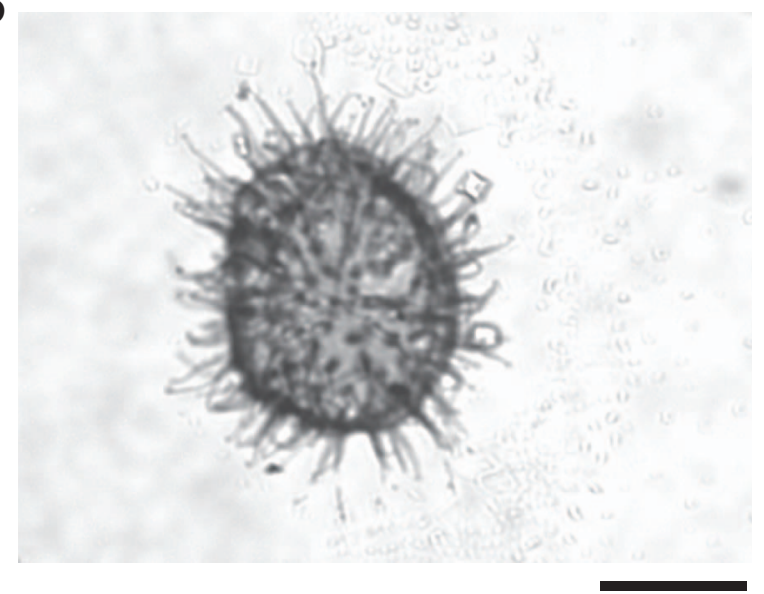


Plate P10. 1. Protoperidinium sp. (Sample 318-U1356A-1R-CC). 2. Selenopemphix sp. A (Sample 318-U1356A-1R-CC). 3. Selenopemphix nephroides (Sample 318-U1356A-78R-CC). 4. Spinidinium macmurdoensis (Sample 318-U1356A72R-CC). 5, 6. Spinidinium schellenbergii; (5) Sample 318-U1356A-82R-CC, (6) Sample 318-U1356A-93R-CC. Scale bars $=20 \mu \mathrm{m}$.

1

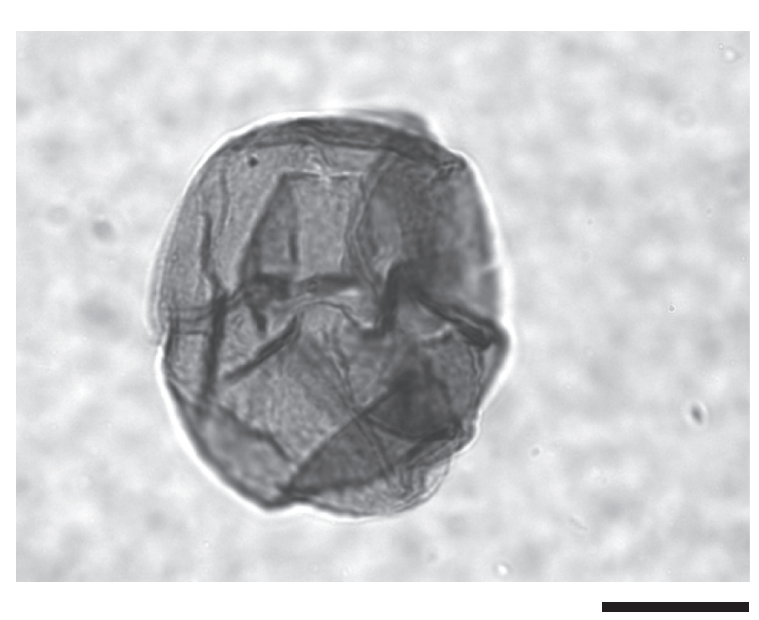

3

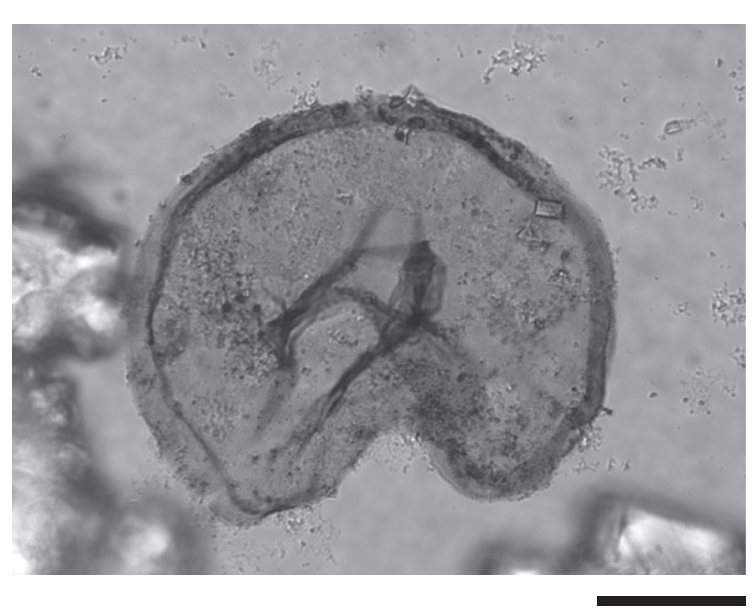

5

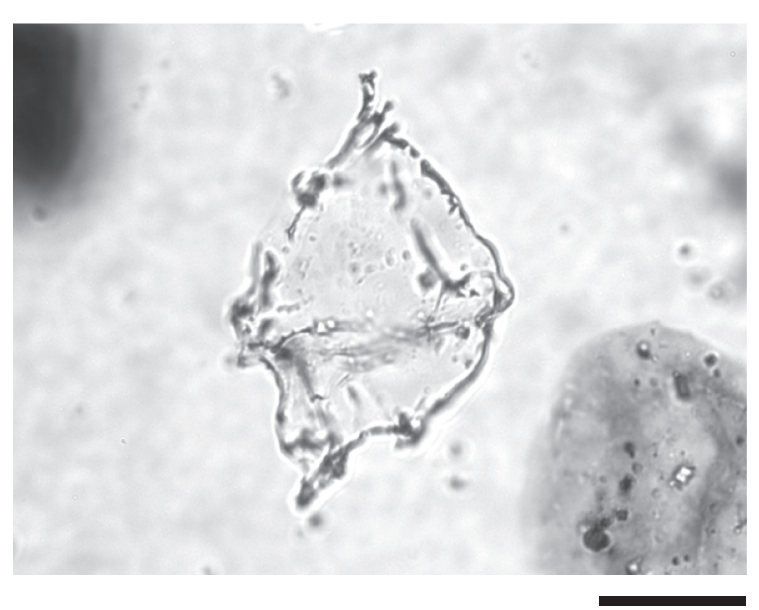

2

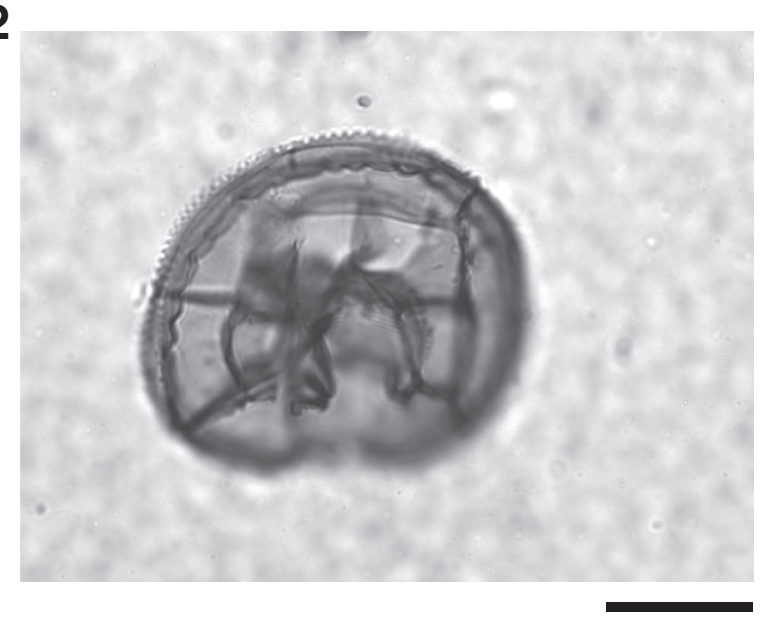

4

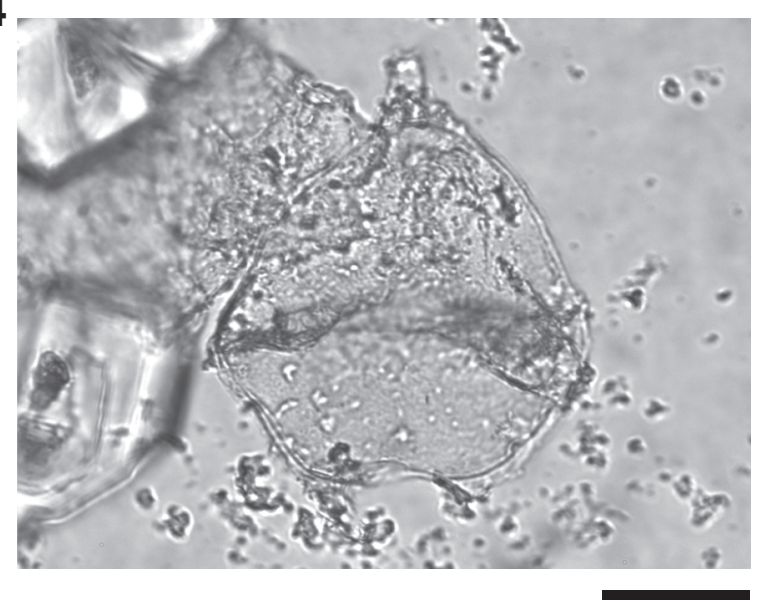

6

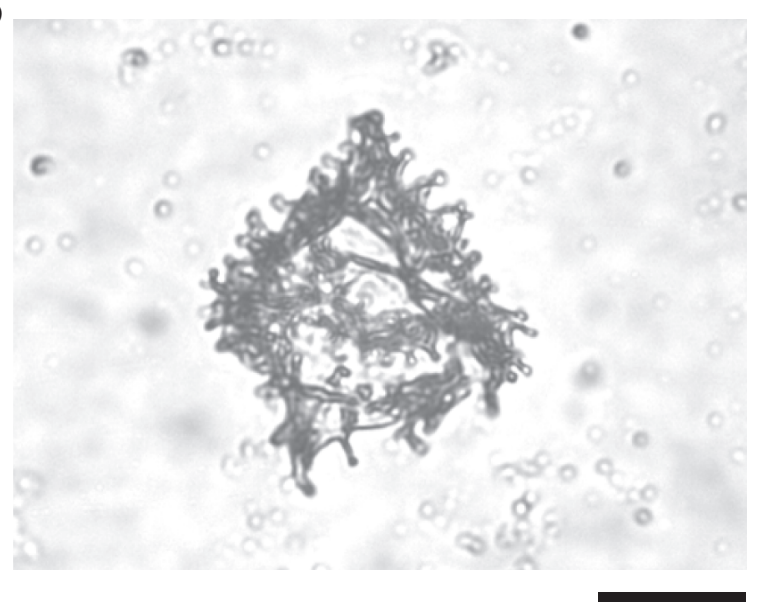


Plate P11. 1. Spinidinium schellenbergii (Sample 318-U1356A-93R-CC). 2. Wetzeliella sp. (Sample 318-U1356A93R-CC). Scale bars $=20 \mu \mathrm{m}$.

1

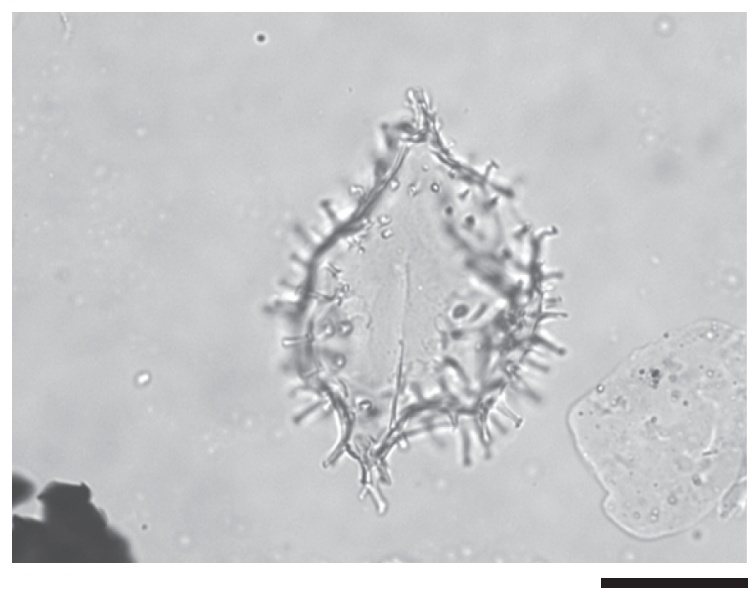

2

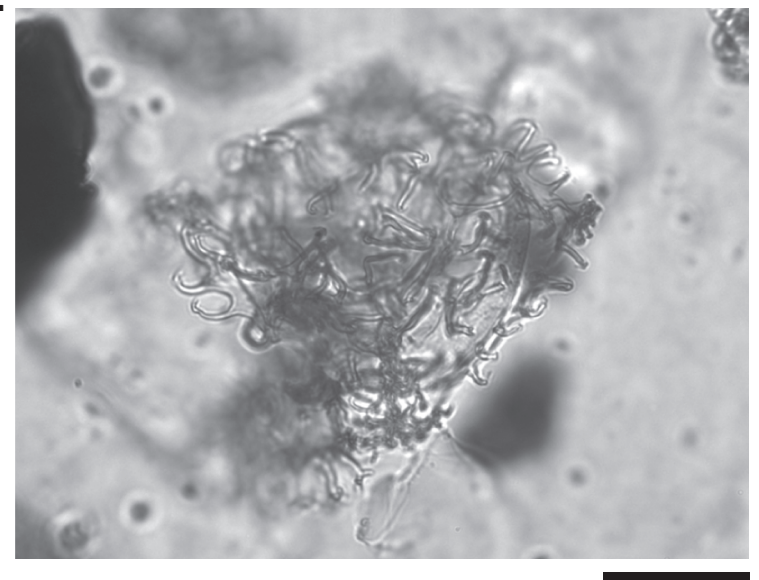


Plate P12. 1. Bisaccate pollen grain (Sample 318-U1356A-11R-CC). 2. Callialasporites turbatus (30 $\mu \mathrm{m})$ (Sample 318-U1356A-11R-CC). 3. Classopollis torosus (Sample 318-U1356A-11R-CC). 4. Nothofagus sp. (Sample 318U1356A-14R-CC). 5. Paleozoic spore, gen. et sp. indet. (Sample 318-U1356A-63R-CC). 6. Triancoraesporites sp. (Sample 318-U1356A-84R-CC). Scale bars $=20 \mu \mathrm{m}$.

1

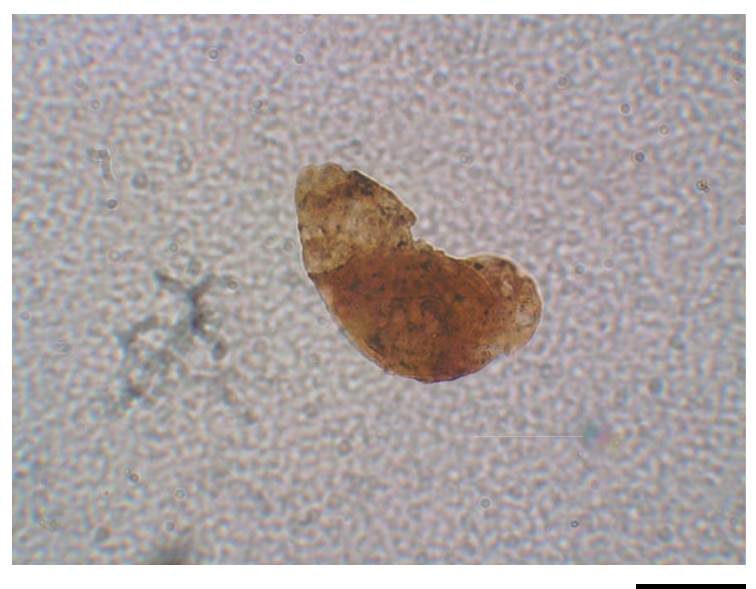

3

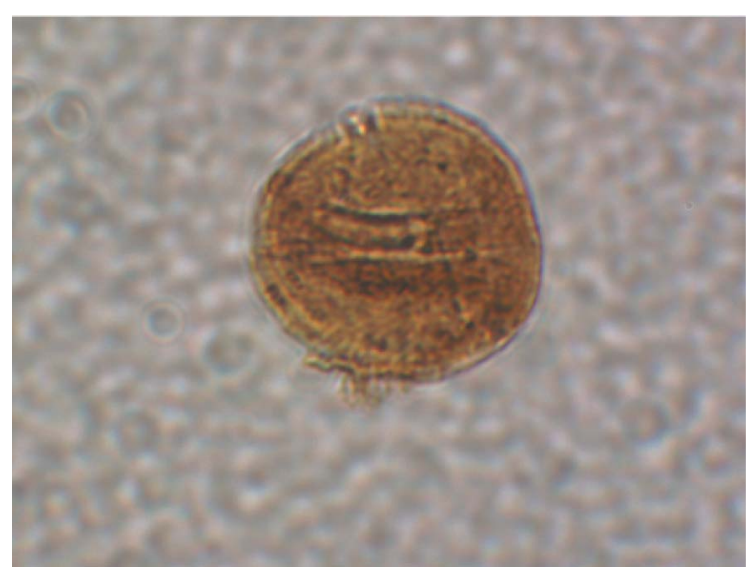

5

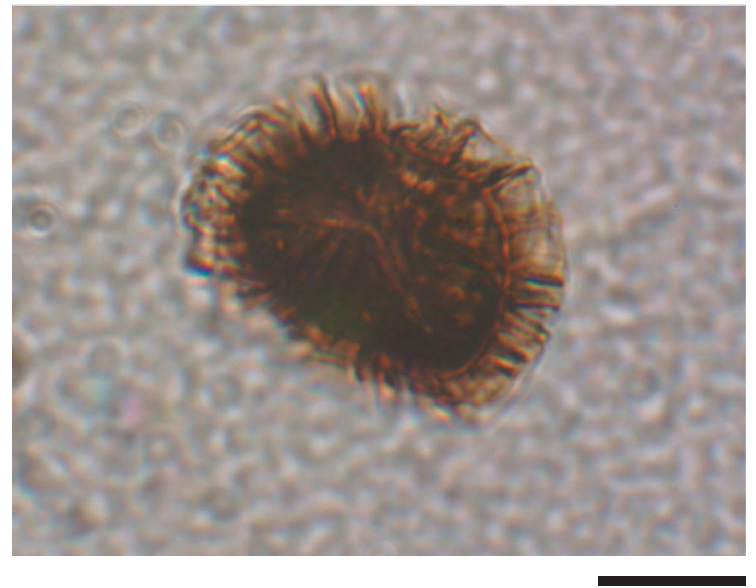

2

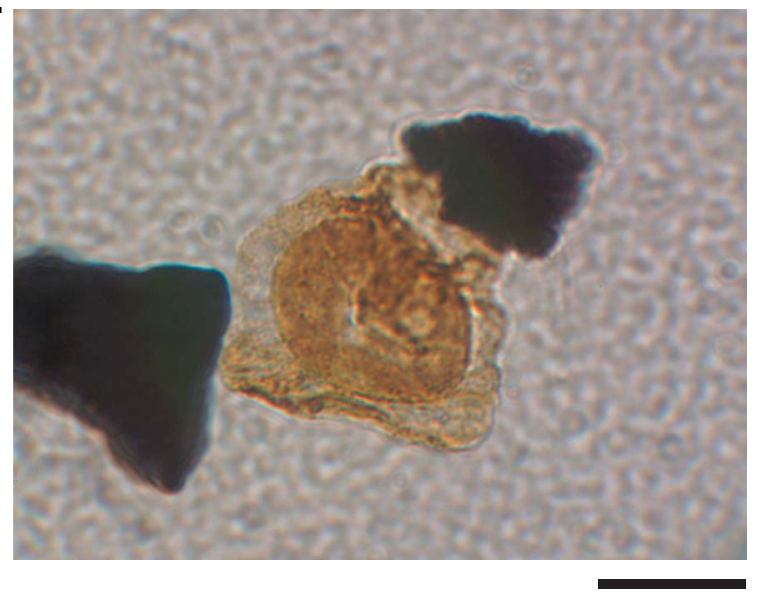

4

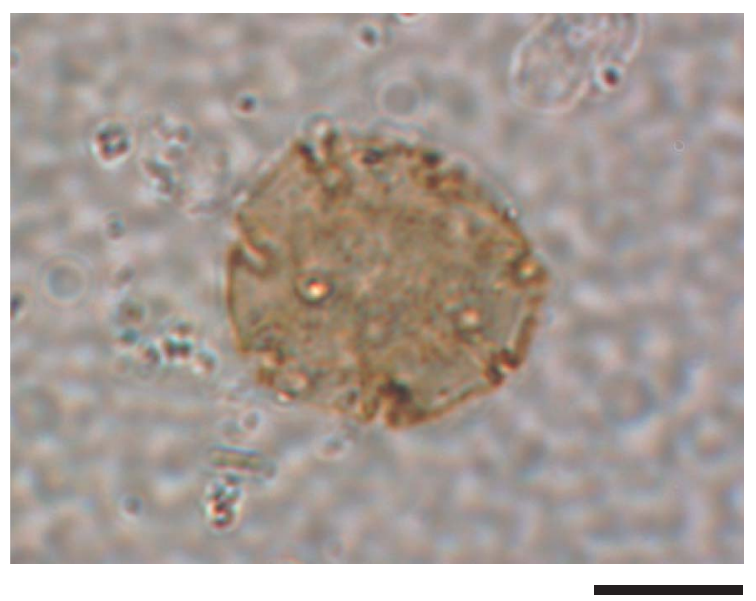

6

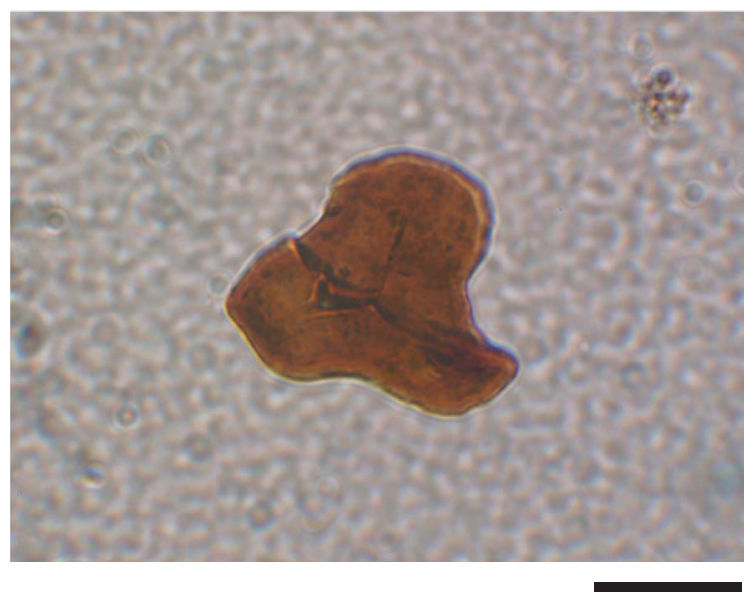

